T.C.

MARMARA ÜNIVERSITESI

SOSYAL BILIIMLER ENSTITÜSÜ

İŞLETME ANABİLİ DALI

ÜRETIM YÖNETIMİ VE PAZARLAMA BİLIM DALI

\title{
INFOMERCIAL REKLAMLARIN \\ (TANITICI REKLAMLARIN) SATIN ALMAYI \\ ETKİLEYEN FAKTÖRLER AÇISINDAN \\ DEĞERLENDİRILMESİ
}

Yüksek Lisans Tezi

ÖZGE SUBAŞI

İstanbul, 2011 
T.C.

MARMARA ÜNIVERSITESI

SOSYAL BILIIMLER ENSTITÜSÜ

İSLETME ANABİLİ DALI

ÜRETIM YÖNETIMİ VE PAZARLAMA BİLIM DALI

\title{
INFOMERCIAL REKLAMLARIN \\ (TANITICI REKLAMLARIN) SATIN ALMAYI \\ ETKİLEYEN FAKTÖRLER AÇISINDAN \\ DEĞERLENDİRÍLMEİ
}

\author{
Yüksek Lisans Tezi \\ ÖZGE SUBAȘI \\ Danışman: YRD. DOÇ. DR. AZRA BAYRAKTAR
}

İstanbul, 2011 


\section{Marmara Üniversitesi \\ Sosyal Bilimler Enstitüsü Müdürlüğü}

\section{Tez Onay Belgesi}

IŞLETME Anabilim Dalı ÜRETIM YÖNETIMI VE PAZARLAMA Bilim Dalı Yüksek Lisans öğrencisi ÖZGE SUBAŞI nın INFOMERCIAL REKLAMLARIN (TANITICI REKLAMLARIN) SATIN ALMAYI ETKILEYEN FAKTÖRLER AÇISINDAN DEĞERLENDIRILMESI adlı tez çalışması, Enstitümüz Yönetim Kurulunun 01.06.2011 tarih ve 2011-10/24 sayılı kararıyla oluşturulan jüri tarafından oybirliğ/oyçokluğu ile Yüksek Lisans Tezi olarak kabul edilmiştir.

Tez Savunma Tarihi : $29.06,2011$

1) Tez Danışmanı : YRD. DOÇ.DR. AZRA BAYRAKTAR

2) Jüri Üyesi : DOÇ. DR. MEHMET TIĞLI

3) Jüri Üyesi $\quad$ : YRD. DOÇ.DR. AYŞE BAHAR CERITOĞLU

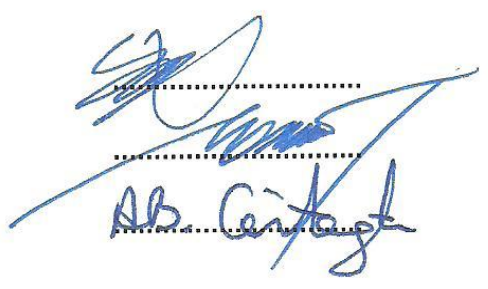




\section{ÖZET}

\section{INFOMERCIAL REKLAMLARIN (TANITICI REKLAMLARIN) \\ SATIN ALMAYI ETKILLEYEN FAKTÖRLER AÇISINDAN \\ DEĞERLENDÍRILMESI}

$\mathrm{Bu}$ çalışma, tüketicilerin infomercial reklamlara yönelik tutumlarını ve tutumun satın alma kararı üzerindeki etkisini belirlemek amacıyla yapılmıştır. Infomercial reklam, doğrudan tepki televizyon pazarlamasında kullanılan bir yöntem olarak karşımıza çıkmaktadır. Doğrudan tepki televizyon pazarlaması ise doğrudan pazarlamanın televizyon aracılığıyla yapılmasıdır. $\mathrm{Bu}$ nedenden ötürü çalışmanın başında doğrudan pazarlamadan bahsedilmiş, daha sonra doğrudan tepki televizyon pazarlaması incelenmiş, ikinci bölümde ise tüketici davranışı ve satın alma karar süreçlerinden söz edilmiştir.

Geleneksel reklamlardan uzun süren, ürünün özelliklerinin ve kullanım şekillerinin bir sunucu, ünlü veya halktan ürünü deneyen bir kişi tarafından anlatılan, ücretsiz telefon numarası ve/veya internet adresinden doğrudan satış yapan reklamlara infomercial reklam denilmektedir. Çalışma kapsamında infomercial reklama yönelik tutumu etkilediği düşünülen; infomercial reklama yönelik alg1, infomercial reklamdan satın alan kişinin özellikleri ve infomercial reklam içeriği ile, tutumdan etkilendiği düşünülen satın alma kararından oluşan bir model oluşturulmuş ve aralarındaki ilişkiler araştırılmıştır. Ayrıca çalışmaya katılanların demografik özellikleri ile televizyon izleme alışkanlıkları ile araştırma konusu faktörler arasında bir farklılık olup olmadığı incelenmiştir.

Araştırma yönetimi olarak hem kalitatif hem de kantitatif araştırma türleri kullanılmış, kalitatif kısım için odak grup çalışmalarından, kantitatif kısım içinse anketlerden yararlanılmıştır. Araştırma sonucunda ortaya konulan bulguların ve modelin doğrudan pazarlama, doğrudan tepki pazarlaması ve infomercial reklam yazınına katkıda bulunması hedeflenmektedir.

Anahtar kelimeler: doğrudan pazarlama, doğrudan tepki televizyon pazarlaması, infomercial/tanıtıcı reklam 


\section{ABSTRACT \\ EVALUATION OF INFOMERCIAL ADVERTISEMENTS IN TERM OF COSTUMER BEHAVIOUR AND THE EFFECT WHICH INFLUENCES COSTUMER BEHAVIOUR PROCESS}

This study is based on the consumer's attitude towards the infomercial and impact of attitude on the purchase decision. Infomercial is a method which is used in the direct response television marketing. Direct response television marketing is direct marketing which is done through television. Therefore, direct marketing and direct response television marketing is mentioned in the first chapter, and consumer behaviour and purchase decision process is mentioned in the second chapter.

Infomercial, or long form informational commercial, is a paid form of advertisement that lasts from 30 minutes to up to 2 hours and is usually aired during inexpensive media blocks. This study establishes a model which effects the consumer perception towards the infomercial, infomercial shopper's specification, infomercial's content affect of consumer attitude towards the infomercial and consumer attitude towards the infomercial that effects the purchase behaviour, and examined the relationship between eachother. Besides, this study also seeks the similarities and differences between demographical charactheristics and habit of watching television of infomercial shoppers who joined this examination and the factors of this study.

Combination of both qualitative and quantitative research methods are used as research method in this study. Focus groups are applied as the qualitative research and surveys are applied as the quantitative research. The aim is making a contribution to direct marketing, direct response television marketing and infomercial literature with the findings and the model of the research.

Key words: direct marketing, direct response television marketing, infomercial 


\section{TEŞEKKÜR}

Çalışmamın her aşamasında desteğini, bilgisini ve pozitif enerjisini
benden esirgemeyen ve bana daima yol gösteren, danışmanım Yrd. Doç. Dr. AZRA BAYRAKTAR'A teşekkürü bir borç bilirim.

Desteğini ve bilgisini hiçbir zaman esirgemeyen, Öğretim Görevlisi AHMET BAŞÇI'ya ve Araştırma Görevlisi İ. GÖKHAN CINTAMUR'a, araştırma kısmında Araştırma Görevlisi Dr. ATA ÖZDEMİRCİ'ye bana ayırdıkları zaman ve katkılarından ötürü çok teşekkür ediyorum.

Her stresli anımda yollara düşüp, çare aradığımız gibi birlikte, tezimi yazarken de bana sabır ve sevgisini gösteren, sahip olduğum en değerli varlığım, annem SEMA SUBAŞI'na, hayatımdaki en büyük yere sahip ağabeyim ÖZGENÇ SUBAŞI'na ve her an ailesi için çabalayan biricik babam ZAFER SUBAŞI'na minnettarım.

$\mathrm{Bu}$ süreçte beni hiç yalnız bırakmayan ve daima destek olan sevgili arkadaşlarım, SİNEM SERTKAYA, DAMLA YILMAZOĞLU ve FİLİZ BÜKİM'e hayatımda oldukları için ve destekleri için teşekkür ederim. 


\section{İÇINDEKIILER}

ÖZET

ABSTRACT ........................................................................................................... ii

İÇINDEKILER ............................................................................................................ iv

TABLO LISTESİ .................................................................................... vii

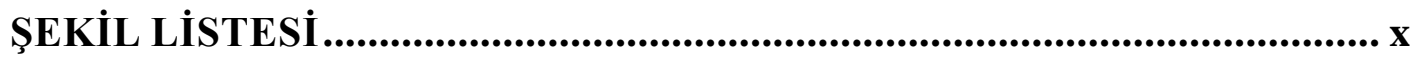

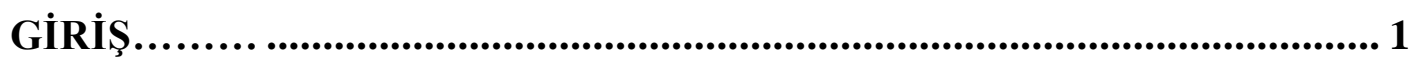

1. BÖLÜM DOĞRUDAN PAZARLAMA ........................................ 2

1.1. Doğrudan Pazarlamanın İçeriği ve Özellikleri ............................................. 2

1.1.1. Doğrudan Pazarlamanın Tanımı ve Kapsamı ....................................... 2

1.1.2. Doğrudan Pazarlamanın Özellikleri..................................................... 3

1.1.3. Doğrudan Pazarlamanın Tarihsel Gelişimi ............................................ 4

1.1.4. Doğrudan Pazarlamanın Gelişmesinde Etkili Olan Başlıca Faktörler .... 6

1.1.5. Doğrudan Pazarlama Kavramı ile Karıştırılan Kavramlar...................... 9

1.1.6. Doğrudan Pazarlamanın Amacı ........................................................... 10

1.1.7. Doğrudan Pazarlamanın Geleneksel Pazarlama İçerisindeki Yeri ve

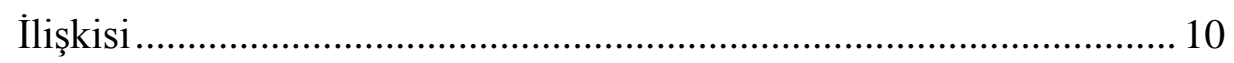

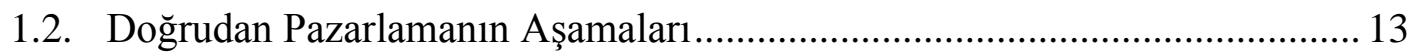

1.3. Doğrudan Pazarlamanın Üstün ve Zayıf Yönleri .......................................... 14

1.4. Doğrudan Pazarlamanın Bileşenleri ........................................................... 20

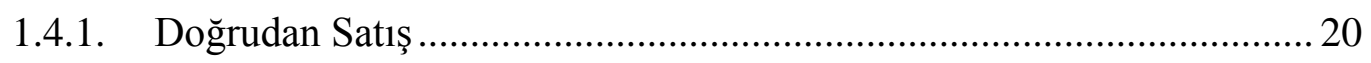

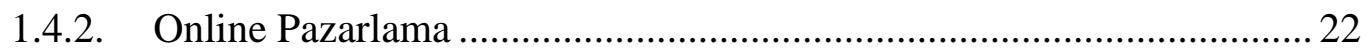

1.4.3. Yeni Dijital Doğrudan Pazarlama ........................................................2 25

1.4.4. Telefon ile Pazarlama............................................................................ 26

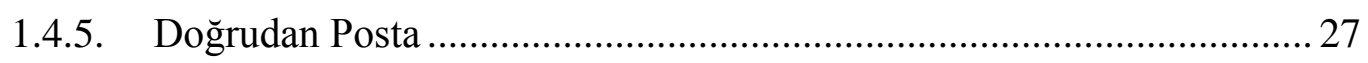

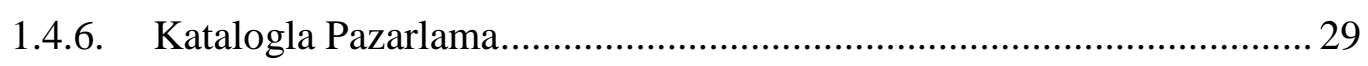

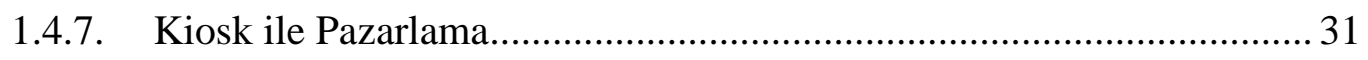

1.4.8. Doğrudan Tepki Televizyon Pazarlamas1 ........................................... 32

1.4.8.1. Home shopping kanalları ..................................................... 35

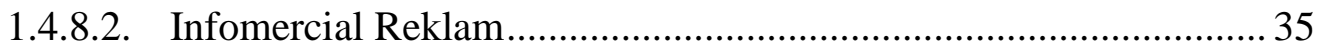




\section{BÖLÜM TÜKETICI DAVRANIŞI VE TÜKETİCI DAVRANIŞINI} ETKILLYEN FAKTÖRLER........................................................... 48

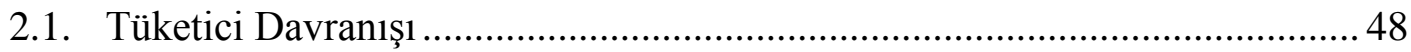

2.2. Tüketici Satın Alma Karar Süreci ............................................................. 49

2.3. Tüketici Davranışını Etkileyen Faktörler .....................................................52

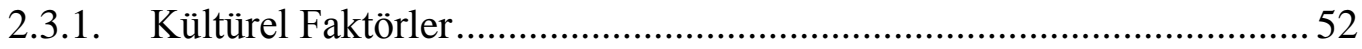

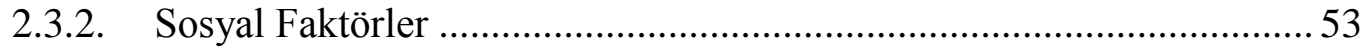

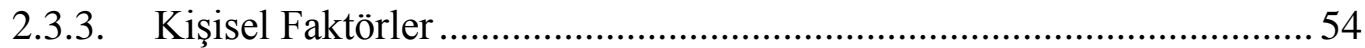

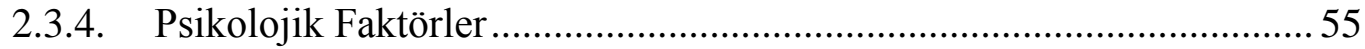

2.3.5. Tutum ve Reklama Yönelik Tutum....................................................59

2.3.5.1. Tutum Kavramı ve Tüketici Davranışları Açısından Tutum

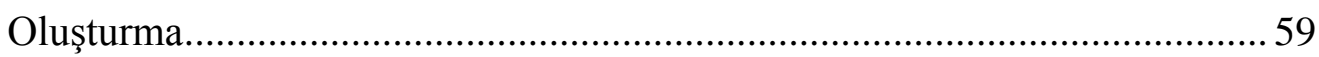

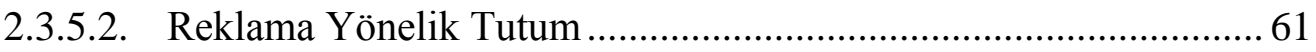

2.4. Tüketici Davranışını Etkileyen Faktörler ve Infomercıal Reklamlar Üzerine Literatürde Yapılan Çalışmalar 64

\section{BÖLÜM INFOMERCIAL REKLAMLARIN SATIN ALMAYI} ETKILEYEN FAKTÖRLER AÇISINDAN DEĞERLENDİRILMESINE İLIŞKİN BİR UYGULAMA .............. 68

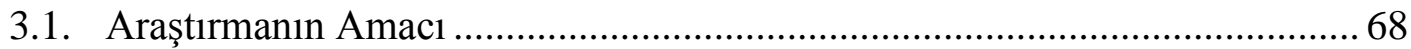

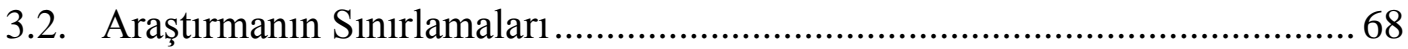

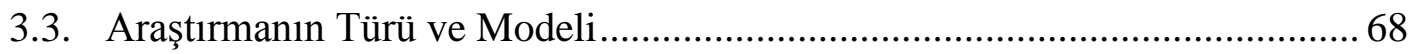

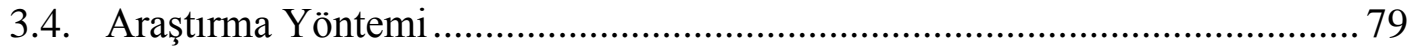

3.4.1. Ana Kütle ve Örnek Kütlenin Seçimi ................................................... 79

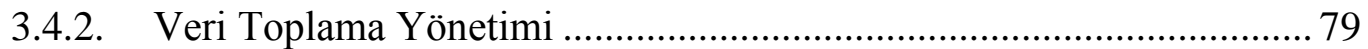

3.4.3. Anket Sorularının Hazırlanması ........................................................... 85

3.4.4. Verilerin Analizinde Kullanılan İstatistiki Yöntemler......................... 85

3.5. Araştırma Bulguları ve Bulguların Değerlendirilmesi .................................. 86

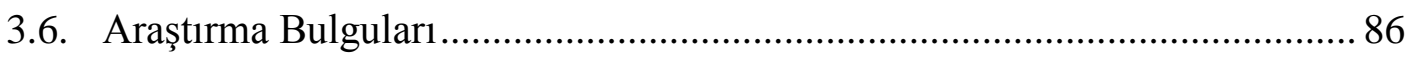

3.6.1. Demografik Özelliklere Yönelik Bulgular.......................................... 86

3.6.2. Infomercial Reklamdan Satın Almaya Yönelik Bulgular .................... 95 
3.6.3. Faktör Analizleri ve Güvenirlik Analizleri .99

3.6.3.1. Infomercial Reklama Yönelik Alg1 Ölçeği için Faktör Analizi ve Güvenilirlik Analizi 99

3.6.3.2. Alıcının Kişilik Özellikleri Ölçeği için Faktör Analizi ve Güvenilirlik Analizi 101

3.6.3.3. Infomercial Reklam İçeriği Ölçeği için Faktör Analizi ve

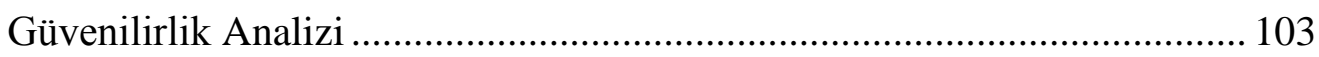

3.6.3.4. Tutum Kavramının Faktör ve Güvenilirlik Analizi ...................... 105

3.6.3.5. Satın Alma Kavramının Faktör ve Güvenilirlik Analizi ............... 105

3.6.4. Ölçekler İçin Doğrulayıcı Faktör Analizleri ...................................... 107

3.6.5. Araştırma Sonuçlarının Yapısal Eşitlik Modeliyle Analizi ................ 112

3.6.6. Araştırmanın Hipotezleri ve Hipotezlerin Test Edilmesi................... 119

3.6.7. Infomercial Reklamlardan Şimdiye Kadar Ürün Satın Alanlar ile Almayanların Karşı 1 aştırılması ......................................................... 136

3.7. Araştırma Bulgularının Değerlendirilmesi................................................ 143

SONUÇ........................................................................................................................................ 155

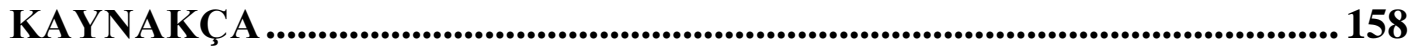

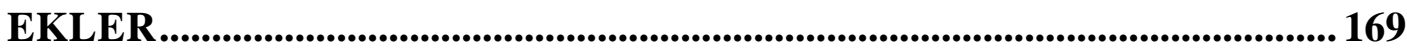




\section{TABLO LISTESI}

Tablo 1: Doğrudan Pazarlama ve Geleneksel Pazarlama Arasındaki Temel Farklar..... 12

Tablo 2: Doğrudan Pazarlamanın Tüketiciler ve Satıcılar Açısından Faydaları 16

Tablo 3: Doğrudan Pazarlamanın Uygulanması için Öneriler. 19

Tablo 4: Infomercial reklam tutumuna yönelik likert ifadeler .74

Tablo 5: Alıcının kişilik özelliklerine yönelik likert ifadeler .75

Tablo 6: Infomercial reklam içeriğine göre yönelik likert ifadeler .76

Tablo 7: Satın alma kararına yönelik likert ifadeler .78

Tablo 8: Ev Hanımları ile Yapılan Odak Grup Çalışması..... 80

Tablo 9: Emekliler ile Yapılan Odak Grup Çalışması 81

Tablo 10: Öğretmenler ile Yapılan Odak Grup Çalışması 82

Tablo 11: Öğrenciler ile Yapılan Odak Grup Çalışması

Tablo 12:Örneklem Grubunun Cinsiyete Göre Dağılımı

Tablo 13:Örneklem Grubunun Yaşa Göre Dağılımı .88

Tablo 14:Örneklem Grubunun Medeni Duruma Göre Dağılımı

Tablo 15: Örneklem Grubunun Sahip Olduğu Çocuk Sayısına Göre Dağglımı 90

Tablo 16: Örneklem Gurubunun Aylık Gelir Düzeyine Göre Dağılımı .91

Tablo 17: Örneklem Grubunun Haneye Giren Aylık Gelirine Göre Dağılımı .92

Tablo 18: Örneklem Grubunun Eğitim Düzeyine Göre Dağglımı .93

Tablo 19: Örneklem Grubunun Meslek Grubuna Göre Dağılımı..... .94

Tablo 20: Örneklem Grubunun Infomercial Reklamlardan Alışveriş Yapmaya Yönelik Dağılımı .95 
Tablo 21: Örneklem Grubunun Infomercial Reklamlardan Satın Aldığı Ürüne Göre Dağılımı

Tablo 22: Örneklem Grubunun Haftalık Televizyon İzleme Oranlarına Göre Dağılımı 97 Tablo 23: Örneklem Grubunun Saatlik Televizyon İzleme Oranlarına Göre Dağılımı . 98

Tablo 24: KMO ve Bartlett Testi Sonuçları. 99

Tablo 25: Infomercial Reklama Yönelik Alg1 Ölçeği için Faktör Analizi 100

Tablo 26: Alıcının Kişilik Özellikleri Ölçeği için Faktör Analizi 102

Tablo 27: Infomercial Reklam İçeriği Ölçeği için Faktör Analizi. 103

Tablo 28: KMO ve Bartlett Testi Sonuçları. 105

Tablo 29: Satın Alma Kavramının Faktör Analizi 106

Tablo 30: Modelde Kullanılan Örtük Değişkenler .... 108

Tablo 31: Modeldeki Değişkenlere Ait Uyum İndeksleri 112

Tablo 32: Modeldeki Değişkenlere Ait Uyum İndeksleri 119

Tablo 33: Algı, Kişilik ve Reklam İçeriği Alt Boyutlarının Cinsiyete Göre Dağılımı. 120 Tablo 34: Bilgilendiricilik Faktörünün Yaş Gruplarına Göre Dağılımı ANOVA testi Sonucu 122

Tablo 35: Çeşitlilik ve Düşünmeden/Fevri Hareket Etme Faktörünün Yaş Gruplarına Göre Dağılımı WELCH VE BROWN-FORSYTHE testi sonucu. 123

Tablo 36: Risk Faktörünün Haneye Giren Aylık Toplam Gelire Göre Dağılımı WELCH VE BROWN-FORSYTHE testi sonucu 126

Tablo 37: Risk, Eğlendiricilik, Aldatıcılık, Bilgilendiricilik Faktörlerinin Medeni Duruma Göre Dağılımı ANOVA testi Sonucu 129 
Tablo 38: Eğlendiricilik, Bilgilendiricilik, Marka Bilinci, Ödeme Koşulları ve Satın Almadan Önceki Reklam Hk. Düşünce Faktörlerinin Haftalık Televizyon İzleme Alışkanlıklarına Göre Dağılımı ANOVA testi Sonucu 131

Tablo 39: Düşüncesizce/fevri Alışveriş, Yorum ve Satın Almadan Önceki Reklam Hk. Düşünce Faktörlerinin Saatlik Televizyon İzleme Alışkanlıklarına Göre Dağılımı ANOVA testi Sonucu

Tablo 40: Infomercial Reklamlardan Şimdiye Kadar Satın Alanlar ile Almayanların Gelecekte Satın Alma Niyeti Yönünden Karşılaştırılması

Tablo 41: Infomercial Reklamlardan Şimdiye Kadar Satın Alanlar ile Almayanların, Infomercial Reklama Yönelik Genel Tutuma Göre Karşılaştırılması 138

Tablo 42: Infomercial Reklamlardan Şimdiye Kadar Satın Alanlar ile Almayanların, Eğlendiricilik, Bilgilendiricilik ve Aldatıcılık Faktörleri Yönünden Karşılaştırılması 138

Tablo 43: Infomercial Reklamlardan Şimdiye Kadar Satın Alanlar ile Almayanların, Ödeme Şekli ve Hayatı Kolaylaştırma Faktörü Yönünden Karşılaştırılması 139

Tablo 44: Infomercial Reklamlardan Şimdiye Kadar Satın Alanlar ile Almayanların, Yorumlar/Kanıtlar/Karşılaştırma Faktörü Yönünden Karşılaştırılması 140

Tablo 45: Infomercial Reklamlardan Şimdiye Kadar Satın Alanlar ile Almayanların, Satın Almadan Önceki Ürün hk. Düşünce Faktörü Yönüden Karşılaştırılması 141

Tablo 46: Infomercial Reklamlardan Şimdiye Kadar Satın Alanlar ile Almayanların, Satın Almadan Önceki Reklam hk. Düşünce Faktörü Yönüden Karşılaştırılması 141

Tablo 47: Infomercial Reklamlardan Şimdiye Kadar Satın Alanlar ile Almayanların,Saatlik Televizyon İzleme Alışkanlıkları Açısından Karşılaştırılması... 142

Tablo 48: Infomercial Reklamlardan Şimdiye Kadar Satın Almayanların,Saatlik Televizyon İzleme Alışkanlıkları

Tablo 49: Infomercial Reklamlardan Ürün Satın Alanlar ile Satın Almayanların Karşılaştırılması T-Testi 152 


\section{ŞEKIL LISTESİ}

Şekil 1: Doğrudan Pazarlamanın Özellikleri .............................................................. 4

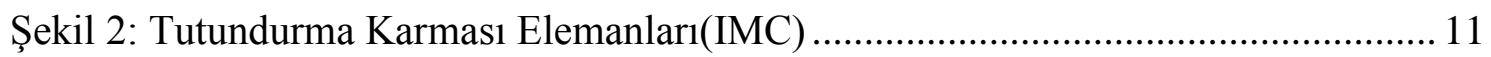

Şekil 3: Doğrudan Pazarlamanın İletişim Şekilleri.................................................... 20

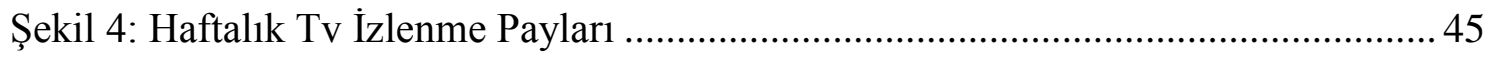

Şekil 5: Satın Alma Karar Sürecinin Aşamaları ........................................................ 49

Şekil 6: Tüketici Davranışını Etkileyen Faktörler ..................................................... 52

Şekil 7:Maslow’un İhtiyaçlar Hiyeraşisi ............................................................... 57

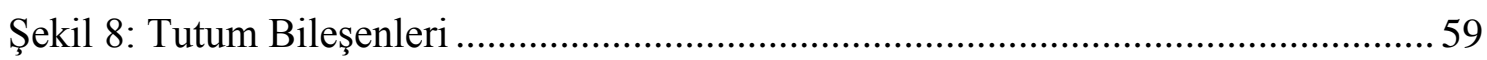

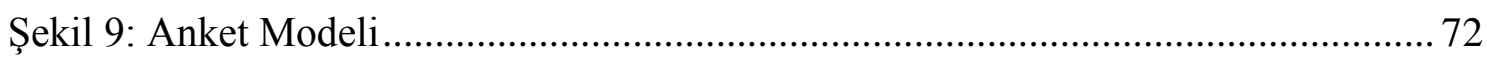

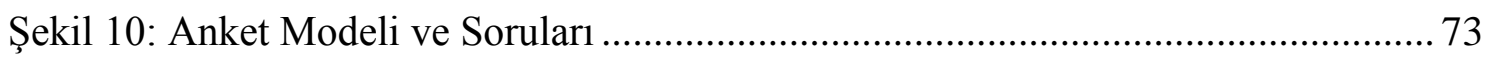

Şekil 11: Örneklem Grubunun Cinsiyete Göre Dağılımı............................................ 87

Şekil 12:Örneklem Grubunun Yaşa Göre Dağılımı................................................... 88

Şekil 13: Örneklem Grubunun Medeni Duruma Göre Dağılımı ................................. 89

Şekil 14: Örneklem Grubunun Sahip Olduğu Çocuk Sayısına Göre Dağılımı............... 90

Şekil 15: Örneklem Gurubunun Aylık Gelir Düzeyine Göre Dağılımı ......................... 91

Şekil 16: Örneklem Grubunun Haneye Giren Aylık Gelirine Göre Dağılımı ................ 92

Şekil 17: Örneklem Grubunun Eğitim Düzeyine Göre Dağılımı ................................. 93

Şekil 18: Örneklem Grubunun Meslek Grubuna Göre Dağılımı ................................... 94

Şekil 19: Örneklem Grubunun Infomercial Reklamlardan Alışveriş Yapmaya Yönelik

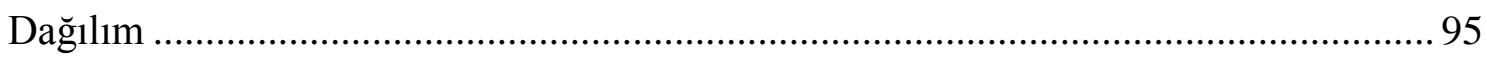


Şekil 20: Örneklem Grubunun Infomercial Reklamlardan Satın Aldığı Ürüne Göre Dağılımı .96

Şekil 21: Örneklem Grubunun Haftalık Televizyon İzleme Oranlarına Göre Dağılımı. 97

Şekil 22: Örneklem Grubunun Saatlik Televizyon İzleme Oranlarına Göre Dağılım.... 98

Şekil 23: Reklama Yönelik Algı Lisrel Çıktısı .......................................................... 109

Şekil 24: Infomercial Reklama Yönelik Alg1 Ölçeği................................................. 109

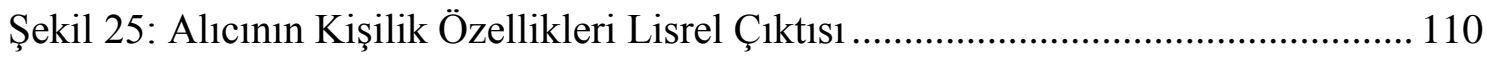

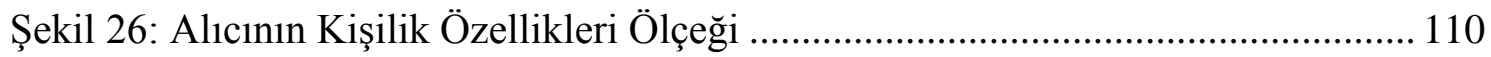

Şekil 27: Infomercial Reklam İçeriği Lisrel Çıktısı.................................................. 111

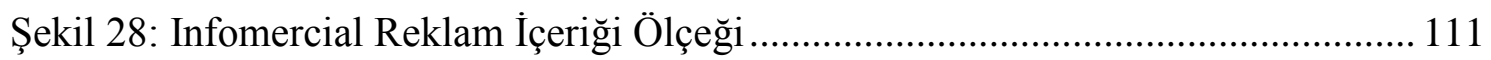

Şekil 29: Açıklayıcı ve Doğrulayıcı Faktör Analizlerinin Ardından Modelin

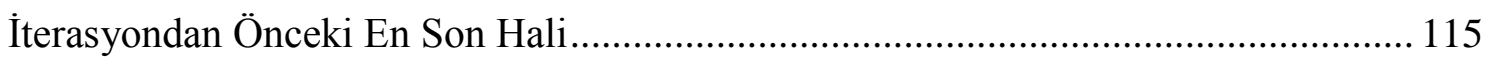

Şekil 30: Tutumu Etkileyen Infomercial Reklama Yönelik Algı Faktörlerinin İterasyon Aracılığıyla En İyi Değerleri Aldı̆̆ı Modelin Lisrel Çıktısı.

Şekil 31:Tutumu Etkileyen Infomercial Reklama Yönelik Algı Faktörlerinin İterasyon Aracılığıyla En İyi Değerleri Aldığı Model.

Şekil 32: Tutumu Etkileyen Alıcının Kişilik Özellikleri Faktörlerinin İterasyon Aracılığıyla En İyi Değerleri Aldığı Modelin Lisrel Çıktısı 118

Şekil 33:Tutumu Etkileyen Alıcının Kişilik Özellikleri Faktörlerinin İterasyon Aracılığıyla En İyi Değerleri Aldığı Model. 118

Şekil 34: Ölçeklerin Doğrulayıcı Faktör Analizleri. 144

Şekil 35:Modelin Önceki Ve Sonraki Halleri 150 


\section{GİRİŞ}

İşletmelerin, reklam, halkla ilişkiler, satış geliştirme, kişisel satış, doğrudan pazarlama gibi iletişim yöntemlerinin desteğine daha fazla ihtiyaç duymalarının sebebi, son yıllarda yoğun rekabete uyum sağlama çabalarından kaynaklanmaktadır. Çünkü pek çok alanda örneğin pazar yapılarında, tüketici ihtiyaçlarında, pazarların yerleşim bölgelerinde, satışa sunulan ürün ve hizmet çeşitlerinde, kısaca pek çok pazarlama alanında değişiklikler meydana gelmiş bu da satış yöntemlerinin değişmesi gerekliliğini getirmiştir. İşte bu nedenlerden ötürü, doğrudan pazarlama, modern pazarlamanın içerisinde yerini almaktadır. (KEEGAN, et al., 2008 s. 489) Dünyada ve de ülkemizde doğrudan pazarlama hayli büyüme göstermektedir.

Doğrudan pazarlama, doğrudan satış, online pazarlama, telefon ile pazarlama, doğrudan posta, katalogla pazarlama, kiosk ile pazarlama ve doğrudan tepki televizyon pazarlaması gibi iletişim şekillerini kullanır. Televizyonun hayatımızdaki önemli etkisiyle doğrudan tepkinin kolaylıkla alınabildiği ve kolaylıkla ölçümlenebildiği doğrudan tepki televizyon pazarlaması yöntemi, evden alışveriş (homeshopping) kanalları ve infomercial reklam olmak üzere iki şekilde karşımıza çıkmaktadır. Infomercial reklamlar, geleneksel reklamlardan uzun sürmektedir, hatta program formatında olabilmektedir. Reklam kuşağının en ucuz saatlerinde yayınlanan reklam

türü, televizyondan kolaylıkla alışveriş yapmak isteyen kitleyi hedef alır. Özellikle Amerika'da kablolu televizyonda gece yarısından sonra gösterilmekte olan reklam türü hayli gelişme göstermektedir. Ülkemizde de son y1llarda infomercial reklamın popülaritesi artmıştır.

Firmaların, ucuz olması ve anında tepki alınabilmesi nedenlerinden ötürü tercih ettikleri yöntemlerden biri olan infomercial reklamlar, eğlendirici içeriği sayesinde izleyicinin de dikkatini çekmektedir. $\mathrm{Bu}$ bağlamda, araştırmanın kapsamında, infomercial reklamın doğrudan pazarlamanın alt başlığı olması nedeni ile doğrudan pazarlamanın içeriği, aşamaları, üstün ve zayıf yönleri, bileşenleri incelenmiş, doğrudan tepki televizyon pazarlamasının iki birleşeninden biri olan infomercial reklamın tanımı, içeriği, bilgilendiricilik unsurları ve ürünü tanıtan kişi kategorileri ile geleneksel reklamla karşılaştırılmasından söz edilmiştir. Ayrıca ikinci bölümde, tüketici davranışı ve tüketici davranışını etkileyen faktörler kapsamında, satın alma karar süreci ve tutum incelenmiş, ayriyeten reklama yönelik tutuma da yer verilmiştir. Daha sonra araştırma kısmına geçilmiştir 


\section{BÖLÜM \\ DOĞRUDAN PAZARLAMA}

\subsection{Doğrudan Pazarlamanın İçeriği ve Özellikleri}

Pazarlama iletişiminin hızla büyüyen yeni yüzü doğrudan pazarlamadır. Doğrudan pazarlama hedeflenen eğilimleri veya birebir pazarlama iletişimini yansıtır. (KOTLER, et al., 2005 s. 476)

\subsubsection{Doğrudan Pazarlamanın Tanımı ve Kapsamı}

Doğrudan pazarlama kavramını literatürde çeşitli kaynaklara göre açıklamak mümkündür.

İlk olarak Lestern Wunderman doğrudan pazarlamayı en özet haliyle, "reklamı ve alışverişi tek bir eylemde birleştiren bir kavram" olarak tanımlamaktadır. (BAYSAL, 2006 s. 42)

Bundan sonraki tanımlar ise doğrudan pazarlamanın özelliklerini açıklamaya yönelik tanımlardır. Örneğin; Berger ve Robert'a göre, “doğrudan pazarlama herhangi bir bölge ya da yerden kolaylıkla ölçülebilir ve istenen bir tepki veya cevap sağlamaya veya etki yaratmaya yönelik olarak bir ya da daha fazla reklam aracını kullanan ve potansiyel müşteri ile ikili bir iletişim sağlayan interaktif bir pazarlama sitemidir." (ROBERTS , et al., 1999 s. 2) Burada doğrudan pazarlamanın kolay ölçülebilir, etkitepki yaratan, birden fazla reklam aracını kullanan, interaktif özelliklerinden bahsedilir. Buna benzer bir tanımı olan Amerikan Doğrudan Pazarlama Derneği'ne göre ise “doğrudan pazarlama, herhangi bir yerde ölçülebilir bir tepkiyi ve/veya hareketi etkilemek için bir veya daha fazla reklam medyasını kullanan interaktif bir pazarlama sistemidir.” (Direct Marketing Associasion (DMA))

Türkiye'de faaliyet gösteren Doğrudan Pazarlama İletişimcileri Derneği’ne (DPID) göre ise, "kitlesel iletişim araçları dışındaki mecraları kullanarak hedef kitle ile marka arasında ilişki kuran, bağlılık yaratan, satın almaya teşvik eden, interaktif, somut, davetkar, katılımcı ve sonuçları ölçülebilen pazarlama iletişimi faaliyetleri” olarak tanımlanmaktadır. (Doğrudan Pazarlama İletişimcileri Derneği) 
Edward Nash'e göre ise, “doğrudan pazarlama, mal ve hizmetlerin kimlikleri belirlenmiş potansiyel müşterilere, normal satış yerlerine (mağazalara) gidilmeden, yani herhangi bir aracı olmadan, satış elemanları ve medya kullanılarak, müşterilerin bulunduğu yerden siparişi vermesi ve teslimatın ya da dağıtımın müşterinin bulunduğu yere yapılması esasına dayanan pazarlama faaliyetleri bütünüdür” şeklinde toparlayıcı bir tanım yapmış ve bu toparlayıcı tanımda Nash, doğrudan pazarlamanın bütün özelliklerini belirtmiştir. (NASH, 1982 s. 1)

\subsubsection{Doğrudan Pazarlamanın Özellikleri}

Çeşitli tanımlardan yola çıkarak doğrudan pazarlamanın temel unsurları aşağıdaki gibidir.

Doğru ve güvenilir bilgilere sahip müşteri veri tabanıyla, doğru bir hedef Pazar seçilebilir. (ROBERTS , et al., 1999 s. 4)

Müşteriye gönderilen mesaj kişisel olarak, yani ismine ya da ilgi alanına göre özel olarak gönderilebilir. (ROBERTS , et al., 1999 s. 5)

Doğrudan pazarlamada çift taraflı bir iletişim söz konusudur. Tüketiciyle kişisel bir iletişim kurulmakla birlikte, tüketiciden de kısa zamanda bir tepki/yanıt beklenebilmektedir. (PIRNAR, 2010 s. 27)

Doğrudan pazarlama da iletişim her yerde olabilir. Yani potansiyel müşterinin bir satış noktasına gelmesi vb. satış ortamında bulunması gerekmemektedir. Evde, iş yerinde, telefonla, televizyonla, bilgisayarla bu etkileşim gerçekleşebilir. Bu nedenle pek çok kaynakta da doğrudan pazarlama için dükkansız perakendecilik kavramı kullanılmaktadır. (KARAFAKİOĞLU, 2006 s. 211)

Doğrudan pazarlama stratejileri kitlesel medyada reklam yapan rakip firmaların stratejilerine göre daha görünmezdir. (ROBERTS , et al., 1999 s. 5)

Doğrudan pazarlama ölçümlenebilmektedir. Müşteriden kişisel yanıt gelmesinin veya gelmemesine göre, hedef kitleye ulaşmak için kullanılan teknik, katlanılan maliyet ve elde edilen tepki ya da sonuç ölçülebilmektedir. (ROBERTS, et al., 1999 s. 5) 
$\mathrm{Bu}$ özelliklere ek olarak Corkell, doğrudan pazarlamanın temel özelliklerini aşağıdaki şekil yardımıyla açıklamıştır.

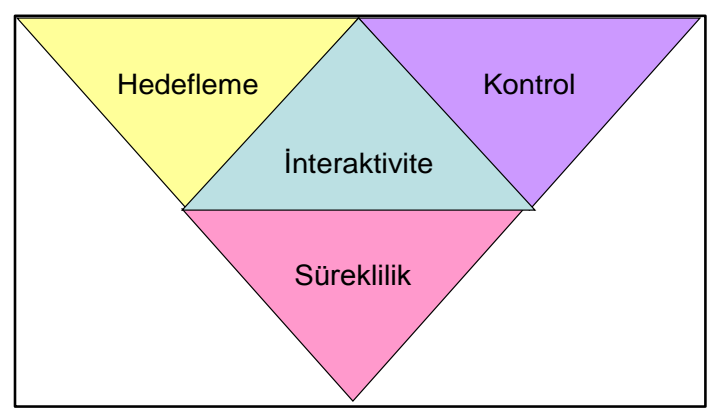

Şekil 1: Doğrudan Pazarlamanın Özellikleri

Kaynak: McCORKELL Graeme Direct and Database Marketing, London : The Institute of Direct Marketing, 1997.

Burada, Hedefleme; daha dar sinırlarla hatta birebir esasıyla hedef kitleyi belirlemeye,

Interaktivite; kurulan karşılıklı iletişime,

Süreklilik; iletişim ve ilişkilerin uzun dönemli olmasına,

Kontrol ise; bir süreç yardımıyla doğrudan pazarlamanın planlanması, uygulanması ve sonuçların değerlendirilmesine karşılık gelir.

Hedefleme üçgeninde hangi hedef kitleye nasıl ulaşacağımız veya bu mesajı nasıl düzenleyeceğimiz yer alır. İnteraktivite üçgeni ortada yer almaktadır. Bunun nedeni, diğer tüm unsurların her birinin tüketicinin tepkisine bağlanacak olmasıdır. Örneğin süreklilik üçgeni müşteriyi elde tutmak, farklı ürünleri onlara satmak ile ilgilidir. İnteraktivite sonucunda elde edilen bilgileri kaydetmek müşteri ile iletişim kurulmasına, müşterilerin ilgilendiklerin şeylerin farkına varılmasına imkân sağlar. Kontrol üçgeni ise hedefleri koymak, stratejik ve işletimsel basamaklarda planlama yapmayı, bütçelemeyi ve sonuçların değerlendirilmesini içerir.

\subsubsection{Doğrudan Pazarlamanın Tarihsel Gelişimi}

Doğrudan pazarlamanın geçmişine baktığımızda 1900'lü yıllar karşımıza çıkmaktadır. Örneğin Doğrudan Pazarlama Derneği, Amerika Birleşik Devletleri’nde 1917 y1lında kurulmuştur (Direct Marketing Associasion (DMA)). Fakat bundan da 
öncesi vardır. 1490'lı yıllardan itibaren kataloglar ile (Venedik'te yazılan kitapların tanıtıldığı) hayatımıza giren doğrudan pazarlama yıllar geçtikçe doğrudan posta kampanyalarına, yazılı basında doğru tepki kampanyalarına, televizyonlara, radyolara ve hatta internete kadar yayılmıştır. (GELLER, 2004 s. 6-7)

Aslında doğrudan pazarlamanın başlangıç noktasını incelerken önce onunla ilgili guruları tanımak gerekir. Nasıl ki pazarlamanın öncüsü olarak Kotler'den söz ediyorsak, üreticiyle son tüketici arasındaki tüm aracıları ortadan kaldıran ve iki tarafı doğrudan temas içine sokan pazarlama yöntemlerinin tümünü kapsayan doğrudan pazarlama disiplini için de üç ayrı öncünün ismi telaffuz edilmektedir. Maxwell Sackheim, Victor O. Schwab ve Lester Wunderman... (BAYSAL, 2006 s. 36)

Wunderman "Doğrudan Pazarlama" terimini ilk kez NewYork’ta, doğrudan postalama alanında faaliyet gösteren şirketlerin yöneticilerinin katıldığı bir toplantıda dile getirmiştir. Bu ifadeyi tercih etmesinin sebebi olarak ise, 'doğrudan satış', 'posta siparişiyle satış’ gibi diğer kavramları yetersiz bulmasından söz etmektedir. Kısaca eskiden "postayla sipariş" olarak tanımlanan kavramı Wunderman geliştirerek “Doğrudan Pazarlama" olarak adlandırmıştır. 1967 yılının Kasım ayında yapılan Massachusetts Institute of Technology'de (MIT) bir toplantıyla doğrudan pazarlamaya olan ihtiyacın nedenini, isminin gerekliliğini ve ismin içeriğini şöyle betimlemiştir (BAYSAL, 2006 s. 42):

"Şu anda bir yeniden kişiselleşme ve bireyselleşme çağında yaşıyoruz. İnsanlar, ürünler ve hizmetler, kısacası herkes ve her şey bireysel bir kimlik arayışı içinde. Beğeniler, arzular, tutkular ve yaşam tarzı tercihleri; alışverişi bir kendini ifade etme biçimine dönüştürmüş durumdadır. Bu gerçekler ile reklamcılık ve satış arasında bir bağlantı kuracak yeni pazarlama biçimlerinin ortaya çıkması gerekiyor. Ve bunu mümkün kılacak bir tek yol var: Reklamı ve alışverişi tek bir eylemde birleştiren DOĞRUDAN PAZARLAMA."

Böylece doğrudan postalama vb. kavramlar yerini doğrudan pazarlama ile değiştirmiştir. Hatta 1917 yılında kurulan Amerikan Doğrudan Postalama Derneği, 1983 yılında ismini bugün kullanılan şekle yani, “Doğrudan Pazarlama Derneği”ne çevirmiştir. (BAYSAL, 2006 s. 40-44) 
1490'lı yıllarda kitap katalogları ile hayatımıza giren doğrudan pazarlama, daha sonra 1700'lü yıllarda Avrupa'da kullanılan bitki ve tohum katalogları olarak karşımıza çıkmaktadır. Bu kataloglar özellikle, kırsal yörelerde yaşayan köylüler için hazırlandıkları görülmektedir. (GÜRAĞAÇ, 2006 s. 7) 1800’lü yılların sonlarında da ABD’de önemli bir katalog örnekleri de karşımıza çıkmaktadır. (ERP Akademi, 2010)

Doğrudan pazarlamanın günümüzdeki şeklini alması ve büyümesi ise 1990 'l1 yıllara denk gelmektedir. Özellikle ülkemizde doğrudan pazarlama faaliyetlerinin gelişmesinin en önemli nedeni olarak kredi kartlarını söylememiz mümkündür. 1990'l1 yıllardan itibaren hayatımıza (ülkemize) giren kredi kartları, doğrudan pazarlamanın ödeme şeklidir ve doğrudan pazarlamanın artışını hızlandırmıştır. (KARAFAKİOĞLU, 2006 s. 211)

\subsubsection{Doğrudan Pazarlamanın Gelişmesinde Etkili Olan Başlıca Faktörler}

Dünyada ve ülkemizde artık dağıtım ve iletişim sistemleri gelişmektedir. Bu nedenle doğrudan pazarlama faaliyetlerinin de gelişmesi kaçınılmazdır. Bu faaliyetlerin gelişmesinin nedenlerini şu şekilde özetleyebiliriz;

\section{Çăğdaş iş yaşamından kaynaklanan gereksinimler; evden alışveriş,} zamandan tasarruf: Doğrudan pazarlama Amerika'da uygulanan en popüler pazarlama tekniğidir. Amerika'da yoğun iş ortamında kendilerine yeterli vakit ayıramayan tüketiciler, satın alma ihtiyaçlarını doğrudan pazarlama şirketlerinden karşılamaktadırlar. Örneğin, düşünüldügüñnde haftanın beş günü dokuz saat çalışmakta, eve yorgun dönülmekte, geriye kalan iki gün ise dinlenmek ve diğer sosyal ihtiyaçları karşılamak için harcanmaktadır. Bu yoğun koşuşturma içerisinde alışveriş ihtiyacını doğrudan pazarlama şirketi karşılamaktadır. (Doğrudan Pazarlama, 2010)

Diğer bir örnek ise, nüfusun artması ve kentlerin karmaşası ve bunun beraberinde getirdiği trafik problemleri ile kişilerin yeteri kadar yoğun çalışma ortamlarında stres yüklü olmaları ve bu kargaşaya boş vakitlerinde de katlanmak istememeleri üzerine verilebilir. Şöyle ki, geleneksel alışveriş ortamlarına gitmek için yine şehrin karmaşasına ve trafiğine girmek gerekecektir. Oysa sadece bir çay tabağına ihtiyacı olan bir tüketicinin, bunun için alışveriş merkezine gitmesi, hem maddi açıdan hem de manevi açıdan düşünüldüğünde "alışverişe gitmişken, yorgunluğuma değsin bari” diyerek, çay tabağının yanında çay kaşı̆̆ını, çay bardaklarını, bunlara uysun diye 
çay tepsisini, peçetelerini de alabilmektedir. Eve geldiğin de ise sizin sadece çay tabağına ihtiyacı olduğunu görmektedir. Oysa doğrudan pazarlama yöntemleri ile, evden ya da istenilen herhangi bir yerden yorulmadan ve sadece ihtiyaç olan, sipariş ederek satın alınabilmektedir.

Dağıtım kanallarının çeşitlenmesi ve gelişmesi: Geçmişte sadece posta yoluyla dağıtım ve tanıtım yapılırken, artık hayatımıza giren televizyon (özellikle kablolu yayın ya da özel tv yayınları), telefon ve internet gibi iletişim araçlarıyla tanıtım kanalları gelişmiş ve de çeşitlenmiştir. Burada aynı zamanda bilgi teknolojilerindeki gelişmelerden de bahsedilebilir.

Bilgi teknolojileri pazarlamacılara, bilgi elde etme ve bilgiyi kullanma kolaylığı sağlamaktadır. Tüm bunların pazarlamacılara sağladığı iki fayda vardır. Bunlardan ilki, işletmelerin faaliyetleri, hizmetleri ve ürünleri ile ilgili bilgileri tüketicilere kapsamlı bir şekilde sunarak, onların karar vermelerine yardımcı olmaktır. İkincisi ise, tüketicilerle birebir iletişim kurabilmektir. Yani, elde edilen bilgilerle, tüketicilerin özelliklerine ve ilgi alanlarına göre içeriği değişebilen, hatta gerekirse sıkılığı da değişebilen mesajlarla iletişim kurulmaktadır. (McCORKELL, 1997 s. 48)

Yeni pazarlama anlayışı; müş̧teri odaklı olmak: Günümüzde artan rekabet ve değişen koşullar nedeniyle tüketicinin karşısına çok fazla seçenek çıkmaktadır. Bu seçeneklerden sıyrılabilmek, firmaların kendilerini daha iyi tanıtmalarını sağlamak ise müşteri odaklı yaklaşmalarına bağlıdır. Doğrudan pazarlamanın ise temel olarak yaptığı işte bu olmaktadır. Kısaca müşteri odaklı pazarlama anlayışı doğrudan pazarlamanın yaygınlaşmasına neden olmuştur. (NAMATOVA, et al., 2007 s. 361-362)

Müşteri odaklı düşünce yapısı, şirketin müşteri ihtiyaçlarını kendi bakış açısıyla değil; müşteri gözüyle belirlemesini gerektirmektedir. Müşteri odaklı pazarlama yaklaşımı pazarlamacıya; çok sayıda veri elde etme, ürün ve/veya hizmet açısından önemli pazar bölümlerini ortaya çıkarma ve dolayısıyla bu bilgiler ışı̆̆ında yatırım geri dönüşü en yüksek olan pazarlama ve iletişim kampanyaları inşa etme yönünde son derece verimli kaynak sağlamaktadır. (UZUNOĞLU, 2007 s. 12)

Tüketici pazarlarının kitlesellikten uzaklaşarak küçük pazar bölümlerine ayrılması, geleneksel kanallar yoluyla tüketici ile iletişim kurmayı zorlaştırmıştır. Tüketici kitlesel olarak değil bir birey olarak görülmek istemektedir. Geleneksel kitle 
iletişim yöntemleriyle bu tarz tüketicilere ulaşmak güçleşmiştir. Oysa ki doğrudan pazarlama, kişiye özel mesajların taşınmasına olanak sağlayan teknikleri bünyesinde bulundurmaktadır. (ODABAŞI, et al., 2002 s. 306-307)

Sosyo-pskilojik davranış biçimindeki değişiklikler: Değişen rekabet faktörleriyle birlikte, yer, fiyat ve kalitenin de değişmesiyle kitlesel üretim yerini, müşterilerle bire bir iletişime bırakmıştır. Bunun sonucunda da firmaların tek çıkış yolu karlı müşterileri tespit ederek onlara yönelik stratejiler kurmak ve onlarla uzun ve etkili bir iletişim içerisine girmektir. Bu nedenle müşteri açısından bir değer yaratılması gerekmektedir. Değer kavramı farklı başlıklar altında incelenmektedir. Bunlardan ilki, "firmanın müşterilerine ne kadar değer katabildiği” olarak açıklanan "müssteri değerinin yaratılması ve iletilmesidir". İkincisi ise, "satış ve kullanım sırasında" "müşterinin algıladığg”" değerdir. Üçüncüsü ise "müşterinin hesaplanan değeri” "müşterinin değeri” şeklindedir. Tüketiciler açısından ise değer kavramı ise düşük fiyat, ürün yada hizmetten beklentiler, ödenen fiyatın karşılığında elde edilen kalite ve toplam faydanın toplam tatmine dönüşmesi şeklindedir. Müşterilerin uzun dönemdeki değerlerini arttırırken neler bekledikleri tespit edilmelidir. (BAYRAKTAR, et al., 2009 s. 233-256)

$\mathrm{Bu}$ bağlamda birbirlerinden farklı görünmek isteyen tüketiciler, doğrudan pazarlama da yeni çıkmış, farklı ve gösterişli ürünlere yönelmektedirler. Ayrıca tüketiciye isim ya da unvanlarıyla gönderilen e-mail, mektup vb. reklam, tanıtım çalışmaları yapan doğrudan pazarlama ile tüketici kendine özel ilgi gösteriliyormuş hissine kapılmakta ve kendini diğer insanlardan farklı görmektedir. (GÜRAĞAÇ, 2006 s. 10)

Doğrudan pazarlamanın kendine has özellikleri: Doğrudan pazarlamanın özellikleri de aynı zamanda gelişmesini etkileyen nedenler arasında sayılabilir. Bunları toparlayacak olursak, müşteriye özel ürün ve hizmet sunumu, seçicilik, esneklik, etkili reklam ve koordinasyonu, kendini ölçebilme yeteneği, uygulamada hizmet anlayışının vurgulanması, kişisellik şeklinde özetleyebiliriz. (PIRNAR, 2010 s. 15) 


\subsubsection{Doğrudan Pazarlama Kavramı ile Karıştırılan Kavramlar}

Doğrudan pazarlama kavramını tarihsel gelişimine baktığımızda doğrudan pazarlamanın evreleri bize doğrudan pazarlama ile halen karıştırılan kavramlar olduğunu göstermektedir. Doğrudan pazarlama ile karıştırılan veya onun yerine kullanılan kavramlardan en çok karıştırılan kavramları gözden geçirmek gerekmektedir.

Örneğin doğrudan reklam, doğrudan pazarlama yerine kullanılmaktadır. Fakat doğrudan reklam doğrudan pazarlamanın kullandığı tekniklerden sadece biridir. Tıpkı, posta ile satış, posta ile sipariş, posta ile reklam kavramları gibi. Bunların hiç biri tek başına doğrudan pazarlamayı açıklayamamakta sadece doğrudan pazarlamanın kullandığı teknikler olarak bilinmektedir. Karıștırılan bir diğer ve en önemli kavramlardan biri de doğrudan satış kavramıdır.

Doğrudan satışın tanımını yapacak olursak, bir mal ya da hizmetin, tüketicilere yüzyüze bir ilişkiyle ve genellikle evlerde, iş yerlerinde ve perakende satış noktası sayılamayacak yerlerde, bir distribütör tarafindan anlatılarak pazarlandığı bir satış yöntemidir. (Çok Katlı Pazarlamaya İlişkin Öğrenmek İstediğiniz Bütün Temel Bilgiler)

Doğrudan satış açısından doğrudan pazarlamanın tanımını Cömert, "ürünlerin, toptancı ve perakendeci gibi aracıları kullanmadan, doğrudan tüketicilere ulaştırılmasına doğrudan pazarlama denir.” şeklinde açıklamıştır. (CÖMERT, 1989 s. 2)

Ayrıca Doğrudan Satış Derneği (DSD), doğrudan satışı kısaca, "tüketim mallarının ve/veya hizmetlerinin doğrudan satıcılar tarafından sabit perakende satış noktalarından uzak yerlerde tüketicilere açıklanarak ve gösterilerek yüz yüze görüşme şeklinde doğrudan satışıdır.” şeklinde açıklamaktadır. (Doğrudan Satış Derneği (DSD), 2010)

Doğrudan reklam açısından doğrudan pazarlamanın tanımını ise Argan, "mevcut ve olası tüketicilere reklam mesajının doğrudan iletilmesi ve onların satın almaya güdülenmesi” şeklinde yapmaktadır. (ARGAN, 1997 s. 5)

Oysa biz doğrudan pazarlamaya baktığımızda, doğrudan pazarlama kavramı tüm bunları kapsamakla birlikte, daha da geniş bir kavram olduğunu görebiliriz. Doğrudan pazarlama tüm pazarlama faaliyetlerinin tüketicinin doğrudan tepki gösterebileceği ve cevap verebileceği biçimde birleştirilip kullanılmasıdır. $\mathrm{Bu}$ sistem; 
posta ile satış, doğrudan reklam ve posta ile reklam tanımlarının hepsini kapsamında bulunduran, teknolojinin yardımı ile üretici/satıcı ve tüketici arasında kolaylıkla bir iletişim sağlanmasına olanak tanıyan bir sistemdir. Doğrudan pazarlama, reklam mesajını doğrudan tüketiciye iletir ve ondan anında olumlu veya olumsuz ama ölçülmesi kolay bir tepki bekler. (NOVICK, 1988 s. 4)

\subsubsection{Doğrudan Pazarlamanın Amacı}

Doğrudan pazarlamanın tanımı ve kapsamının yanı sıra, amacından da söz etmek yerinde olacaktır. Doğrudan pazarlamanın amacı, adayların, potansiyel müşteriye, onların da fiili müşteriye dönüştürülmesine çalışmaktır. Burada sözü edilen adaylar; hakkında çok az bilgiye sahip “ olunan, müşteri olma olasılığı olan grup, potansiyel müşteri; çeşitli biçimlerde işletme ile ilişkiye girmiş olan müşteriler, fiili müşteri ise; işletmeden sürekli ürün alanlar ya da bir zamanlar satın almış olanlardır. Bu bağlamda doğrudan pazarlamanın dört önemli amacından söz edilir; (ODABAŞI, 1995 s. 165)

Şimdiki müşterileri elde tutmak,

Denemeyi ya da marka değiştirmeyi teşvik etmek,

Doğrudan tepki reklamı ile satış yapmak,

Markanın kullanımını ve miktarını arttırmak.

Doğrudan pazarlamanın amacını toparlayarak sadece iki temel kavrama bağlarsak; bunlardan biri yeni müşteri kazanılması, diğeri de mevcut müşterilerin memnuniyetinin sağlanarak uzun vadeli karşılıklı güvene dayalı bir alışveriş ilişkisinin kurulmasıdır. (TIMMERMANS, et al., 1999 s. 247)

\subsubsection{Doğrudan Pazarlamanın Geleneksel Pazarlama İçerisindeki Yeri ve İlişkisi}

Doğrudan pazarlama, pazarlama iletişimi karması içerisinde yerini alır. Firmalar, tutundurma araçlarının bu özel karmasını, pazarlama hedeflerini takip etmek için kullanırlar. 
Doğrudan pazarlamayı bu karma içerisinde şekil yardımıyla göstermek yararlı olacaktır.

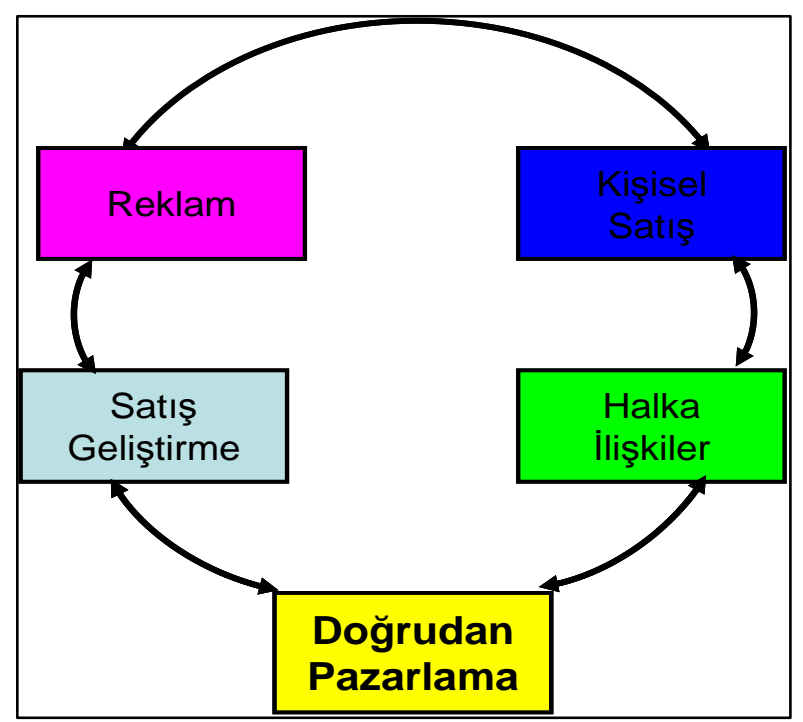

Şekil 2: Tutundurma Karması Elemanları(IMC)

Kaynak: KOTLER Philip ve AMSTRONG Gary Principles of Marketing, Prentice Hall College Div, 2005. - Cilt 11th Edition.

Her bir iletişim karma elemanını açıklayacak olursak; (KOTLER, et al., 2005 s. 427)

Reklam: Fikirlerin, ürünlerin ve hizmetlerin tutundurulmasını sağlamak amacıyla yapılan, kişisel olmayan ücretli bir sunum şeklidir.

Kişisel Satış: Müşteriyle ilişki kurmak ve beklenen satışı yapabilmek için firmanın satış gücü tarafından yapılan kişisel sunumdur.

Satış geliştirme: Kısaca, bir ürün veya hizmetin satışını ve satın alınmasını destekleyen teşviklerdir.

Halkla İlişkiler: Firmaların halk ile iyi ilişkiler kurmasını sağlamak amacıyla, olaylara, öykülere, dedikodulara maruz kalmamak için başvurulan, şirket için iyi bir imaj oluşturabilmek ve bu imajı elinde tutabilmeyi sağlamak amacıyla yapılan olumlu tanitımlardir.

Doğrudan pazarlama ise yukarıda çeşitli tanımlara da rastlayabileceğimiz gibi Kotlere göre kısaca, çeşitli reklam mecralarıyla tüketicinin doğrudan birbirini etkilediği, genellikle tüketicilerin doğrudan tepki verdikleri pazarlama şeklidir. 
Doğrudan pazarlama kavramı geleneksel pazarlama ve diğer iletişim unsurlarından farklıdır. Bu farklılığın en önemli nedenlerinden biri tüketiciye aracısız ulaşarak satış yapabilmek ve eş zamanlı tepki alabilme ve bu tepkiyi kontrol edebilme imkanı tanımaktadır. Tüketicilere kişiselleştirilmiş iletişim araçları ile ulaşılmaya çalışılması da bir diğer özelliğidir. Çünkü geleneksel pazarlamada kitlesellik vardır. Hatta bazı yazarlar bu bağlamda geleneksel pazarlamayı "kitlesel pazarlama", doğrudan pazarlamayı da "belirlenmiş kişi” ya da "işletmelere hitap" olarak ifade etmektedirler. (STONE, 1992 s. 125)

Doğrudan pazarlama ile geleneksel pazarlama arasındaki temel farklılıkları aşağıdaki tabloda özetleyebiliriz.

\begin{tabular}{|c|c|}
\hline Geleneksel Pazarlama & Doğrudan Pazarlama \\
\hline $\begin{array}{l}\text { \# Kitlesel medya aracığıyla geniş kitlelere } \\
\text { ulaşılmaktadır. } \\
\text { \# Illetişim kişisel değildir. } \\
\text { \# Kitlesel medya kullanıldığından } \\
\text { tutundurma programları rakipler tarafından } \\
\text { görünür ve göz önündedir. } \\
\text { \# Tutundurma etkinliklerinin kapsamı ve } \\
\text { niceliği, bütçe büyüklüğüyle ilgilidir. } \\
\text { \# Arzu edilen eylem ya net değildir ya da } \\
\text { gecikmeli gerçekleşir. } \\
\text { \# Karar almada satış ziyareti raporları, } \\
\text { pazarlama araştırması gibi birbirini çoğu } \\
\text { zaman tamamlamayan, örnek niteliğinde } \\
\text { verilerden hareket edilir. } \\
\text { \# Analizler pazar bölümü düzeyinde genel } \\
\text { yapılır. } \\
\text { \# Etkinliğini ölçmek için, reklam } \\
\text { farkındalığı ya da satın alma niyeti gibi } \\
\text { temsilci değişkenler kullanılır. }\end{array}$ & 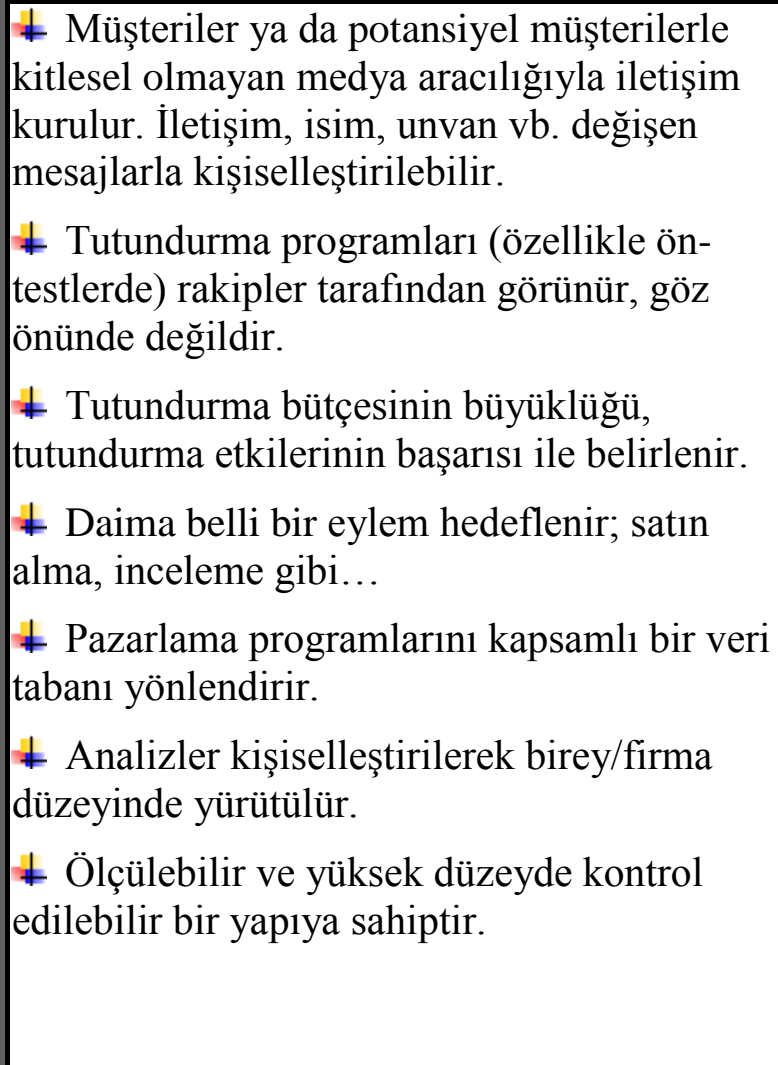 \\
\hline
\end{tabular}

Tablo 1: Doğrudan Pazarlama ve Geleneksel Pazarlama Arasındaki Temel Farklar

Kaynak: ROBERTS Mary Lou ve BERGER Paul D. Direct Marketing Management, London : Prentice Hall International, 1999. - Cilt II. 
Genellikle Tablol'de farklılıklarından bahsettiğimiz doğrudan pazarlama ve geleneksel pazarlama arasında benzerlikler de bulunmaktadır. Bunlar, genel anlamda müşterinin istek ve ihtiyacına yönelik ürün ve hizmet üreterek satmak, araştırma ve geliştirme faaliyetlerine önem vermek, tutundurma faaliyetleri ile ilgili olarak kitle iletişim araçlarından faydalanmaktır. Fakat aralarında her ne kadar benzerlikler bulunsa da kullandıkları yöntemlerin ve uygulama biçimlerinin farklılığı yüzünden, işletmelerde geleneksel pazarlama ile doğrudan pazarlama birimleri genellikle ayrı bölümler olarak görev yapmaktadırlar. (PIRNAR, 2010 s. 34)

\subsection{Doğrudan Pazarlamanın Aşamaları}

Doğrudan pazarlama başlangıç uygulaması ve destek uygulaması şeklinde iki aşamaya sahiptir. Başlangıç aşaması; pazarlama iletişimini kapsayan, bilgi almak ya da satış yapmak için gelen çağrıyı karşılama (inbound) ya da dış arama (outbound) uygulamalarını içermektedir. Destek aşaması ise, siparişlerin süreçlendirilmesi ve kabulü, envanterin kontrolü, siparişlerin taşınması, faturalandırılması ve diğer müşteri hizmetlerini içermektedir. Başlangıç aşamasında beklenti yaratılırken, destek aşamasında bu beklentiler karşılanır. Başlangıç ve destek uygulamalarının en önemli bileşenleri ise, sipariş verme, veri tabanı oluşturma, tepki yaratma ve yerine getirmedir. (DUNCAN, 2001 s. 602-605)

Roberts ve Berger ise bu aşamaları pazarlamanın 4P'sine benzetmektedir. (ROBERTS , et al., 1999 s. 6)

Teklif Verme: $\mathrm{Bu}$ aşamada pazarlamacı tüketiciye ürünle ilgili teklif sunar. $\mathrm{Bu}$ teklifin içerisinde somut ve soyut kavramlar bulunmaktadır. Örneğin ürün burada tanıtılır, ürünün fiyatı verilir. Bunun yanında da ödeme koşulları, garanti, teslim zamanı, ek (hediye) ürünler, görsellik ve marka ile ilgili bilinen diğer bilgiler bu aşamada tüketiciye iletilir. (ROBERTS , et al., 1999 s. 6)

Veri Tabanı: Doğrudan pazarlamanın en önemli aşaması veri tabanıdır. Çünkü doğrudan pazarlama firmaları veri tabanlarındaki müşteri listelerinin kalitesine göre yaşar ve ölürler. Doğrudan pazarlamanın diğer yöntemlere göre maliyetli bir uygulama olduğuna doğrudan pazarlamanın özelliklerini anlatırken değinmiştik. $\mathrm{Bu}$ nedenle müşteriye yapılan ilk satış ile kar nadiren elde edilir. Müşterilerin isimleri, adresleri ve 
ilişkili diğer bilgileri alınarak listelendirilmesiyle, müşteriler ek sipariş teklifleri gönderilir. Böylece bu müşteriler karlı müşteriler haline gelir. (DUNCAN, 2001 s. 603)

Kısaca veri tabanı oluşturulduğunda lider müșteriler yaratılır ve bu müşterileri nitelendirerek onlara, ürün ve hizmet satmak için, aynı zamanda müşterilerle ilişkileri yürütmek için müşterilerin veya potansiyel müşterilerin verilerini organize etmek; veri tabanlı pazarlamayı kısaca açıklayabilmektedir. Başarılı bir doğrudan pazarlama ile iyi bir müşteri veri tabanı oluşturulmaya başlanmıştır. (KOTLER, et al., 1996 s. 479-480)

Tepki: Doğrudan pazarlamada tepki, marka iletişim mesajına yanıt verilmesi şeklinde açıklanmaktadır. Müşteriler bu tepkiyi, ücretsiz numaraları kullanarak, web sitesini kullanarak, davetiyelere yanıt vererek göstermektedirler. (DUNCAN, 2001 s. 605)

Yerine Getirme: Doğrudan pazarlamanın dağıtım tarafı "yerine getirme" aşaması olarak tanımlanmaktadır. Müşteri için fiyatta ve modaya uygun olan bilgi veya ürünün verilmesi bu aşamada gerçekleşmektedir. Bu aşamada bir üst ürün satışı (upselling) yapıldığı gibi, çapraz satış da (cross-selling) yapılmaktadır. (DUNCAN, $2001 \mathrm{~s}$. 605)

\subsection{Doğrudan Pazarlamanın Üstün ve Zayıf Yönleri}

Doğrudan pazarlamanın üstün yönlerini şu şekilde açıklamak mümkündür.

Iletişim: Doğrudan pazarlama sayesinde üreticiler ile tüketiciler arasında sürekli bir iletişim sağlanmaktadır. Bu iletişim müşteriler hakkında detaylı bilgi edinilmesini sağlamaktadır. Böylece de, onların hangi tür mal ve hizmetlere ilgi duyduğu öğrenilebilir. $\mathrm{Bu}$ sayede üreticilerde, satışa sunmak istedikleri ürün veya hizmetlerde değişiklikler yapabilir veya yeni ürün planlayabilirler. (BIRD, 1989 s. 32)

Ayrıca sağlanan bu iletişim avantajı sayesinde öğrenilen, müşteri isim, unvan, adres listesi veya onların satın alma davranışları, onlara kişisel olarak hitap edilmesini sağlamaktadır. Sonuç itibariyle bu da bir firma veya üretici için ayrıcalık sağlar. Böylece firma sadece tek bir satış yerine uzun süreli bir ilişkiyi sürdürebilmektedir. (PIRNAR, 2010 s. 40)

Tepki: Doğrudan pazarlama müşteriden tepkilerini hemen alabilmekte, hatta onlarla interaktif bir iletişimde bulunabilmektedir. Müşteriden gelecek tepki veya 
müşteri hakkında edinilecek bilgiler çeşitlidir. Bunlar, sadece ürünü ya da hizmeti alıp almayacağına dair bir cevap, üyelik, katılım veya daha fazla bilgi isteme şeklinde olabilmektedir. (NASH, 1982 s. 6)

Seçicilik ve esneklik: Üretici açısından baktığımızda doğrudan pazarlama, üreticinin müşterilerden alıp, veriye dönüştürdüğü bilgiler doğrultusunda, istedikleri müşteri grubuna, istedikleri zaman ürün sunmalarını sağlamaktadır. Özellikle telefon ve bilgisayar gibi kolay tepki alınmasını sağlayan araçlar sayesinde de üretici, daha hızlı sipariş almaktadır.

Tüketici açısından baktığımızda ise, müşterilerin evden ya da istedikleri herhangi bir yerden ürünü/hizmeti satın alabilmesi ve ürünü müşteri o neredeyse oraya teslim edebilme olanağı doğrudan pazarlamanın zaman ve mekân açısından esneklik sağladığını göstermektedir. (PIRNAR, 2010 s. 41)

Fiyat avantajı: Doğrudan pazarlamanın en can alıcı özelliklerinden biri fiyat konusudur. Çünkü doğrudan pazarlamanın satış ve diğer maliyetleri, geleneksel perakende satışına nazaran daha düşük olduğu için, ürünün / hizmetin fiyatları da düşük olabilmektedir. Ayrıca, tüketiciyi bir ürün / hizmeti almaya iten en önemli sebebin fiyat olduğu düşünülürse doğrudan pazarlama fiyat en önemli üstünlüktür. (PIRNAR, 2010 s. 41)

Öte yandan doğrudan pazarlamada birden fazla yöntem kullanılmaktadır. Örneğin bir ürün için hem online, hem televizyon, hem de telefonla pazarlama yöntemleri kullanılabilir. Ya da doğrudan pazarlama her ne kadar mağazasız perakendecilik olarak bilinse de, firma ürünlerini/ hizmetlerini bir yandan mağaza ortamında satarken, bir yandan da doğrudan pazarlama etkinliklerinden de yararlanabilir. Böylece maliyetler artar. Bunun yanında, "kişiselleştirme gerekliliği”" de maliyet arttırıcı bir unsur olarak görülmektedir. (ODABAŞI, et al., 2002 s. 308) (PELTEKOĞLU, 2010 s. 255)

Seçim yapabilme: Doğrudan pazarlamanın iletişim şekillerinden katalogların, özel broşürlerin, televizyonların ve internetin sağladığı geniş imkânı, büyük mağazaların bile sağlaması olanaksızdır. Elde bulunan katalog ve broşürler yardımıyla veya internet taraması ile müşteriler; mektup, telefon veya bilgisayarlar ile siparişleri çabuk ve kolay olarak günün her saatinde yapabilmektedirler. (PIRNAR, 2010 s. 42) 
Reklamı ve satışı birlikte yapabilme: Doğrudan pazarlama, reklam ve satış fonksiyonlarını, tek bir duyuru ve postalama içinde birleştirebilmektedir. (CÖMERT, 1989 s. 49)

Doğrudan pazarlamanın üstünlüklerini özetleyecek olursak; (PELTEKOĞLU, 2010 s. 255)

Doğrudan pazarlama da;

Kişisel iletişim kurulabilir,

Ölçülebilir yanıtlar alınabilir,

Veri toplama imkânı sunar,

Tüketicinin tepkisi alınır.

Ayrıca son olarak, doğrudan pazarlamanın tüketiciler açısından ve satışçılar açısından faydalarına bakmak yararlı olacaktır. (KOTLER, et al., 2005 s. 519)

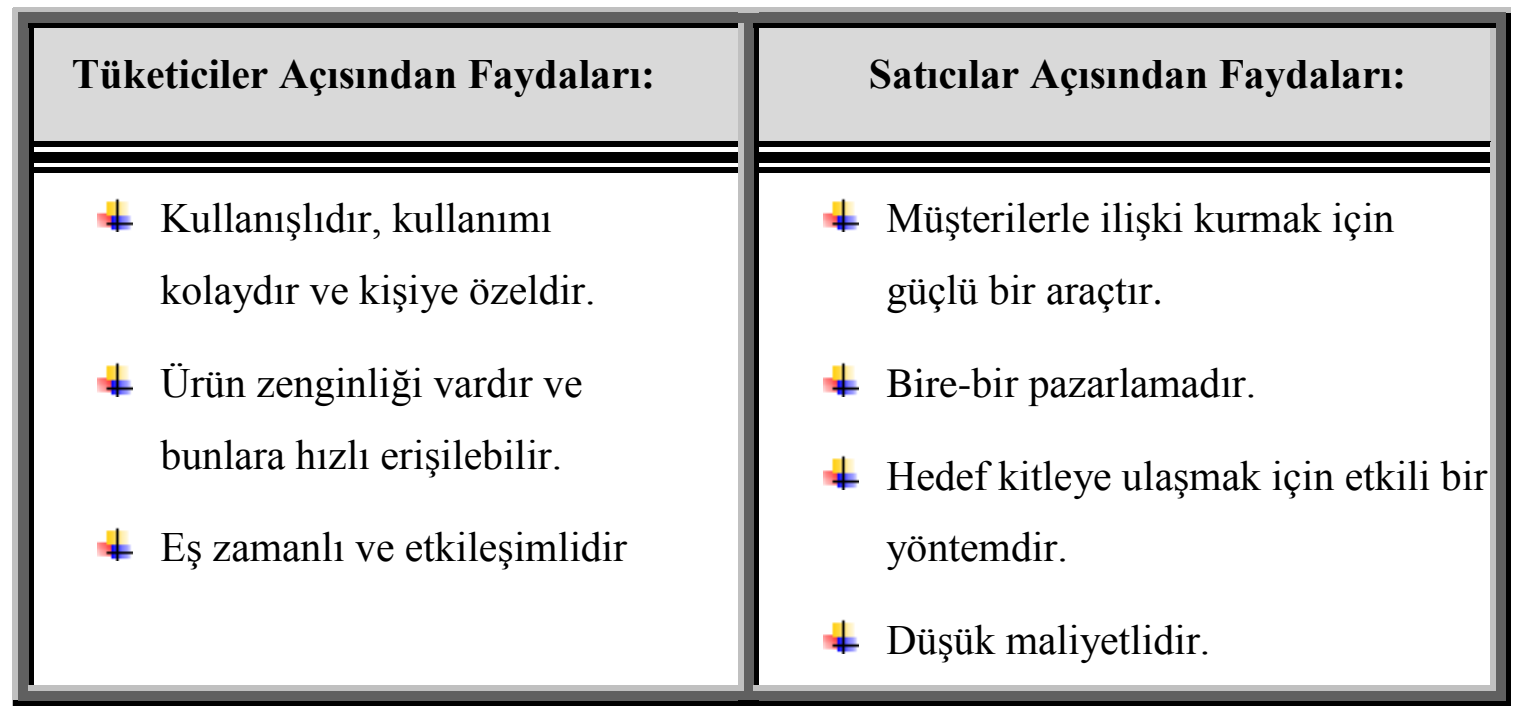

Tablo 2: Doğrudan Pazarlamanın Tüketiciler ve Satıcılar Açısından Faydaları

Kaynak: KOTLER Philip ve AMSTRONG Gary Principles of Marketing,Prentice Hall College Div, 2005. - Cilt 11th. Edition

Doğrudan pazarlamanın zayıf yönlerini incelediğimizde karşımıza birkaç unsur çıkmaktadır. Örneğin fiyat unsurunu bir üstünlük olarak belirtmiştik. Fakat maliyetler açısından bazı yönleriyle dezavantaj konumuna geçmektedir. Örneğin, televizyon ve gazetelere reklam vermek eskisinden çok daha pahalıdır. Ayrıca doğrudan pazarlama müşteriyle ilgili bir veri tabanına sahip olması gereken bir yöntem olduğu için, özel hayatın gizliliği gibi hususlara, çok özen gösterilmelidir. (TAPAN, 1997 s. 50) Özellikle 
internet ortamında iletilerin engelleniyor olması doğrudan pazarlamanın yaşadığı en büyük sıkıntılardan biri olarak karşımıza çıkmaktadır (PELTEKOĞLU, 2010 s. 256). Ayrıca ayıplı ürünlerin gönderilmesi ya da ürün dağıtımındaki aksamalar nedeniyle de sektörün imajı olumsuz etkilenebilmektedir. (TİMUR, et al., 1996 s. 97)

\section{Doğrudan Pazarlamada Karşılaşılan Problemler Ve Bunların Giderilmesine}

\section{Yönelik Öneriler}

Doğrudan pazarlamanın zayıf yönlerini incelemeye devam ettiğimizde karşımıza, üreticinin veya tüketicinin zihnindeki doğrudan pazarlama ile ilgili olan yanlış düşünceler çıkmaktadır. Bunlar; "Doğrudan pazarlamaya asla cevap vermem”, "Perakende satış daha kolaydır", "Yerel basına verdiğim ilanlar pekâlâ işe yarıyor. Benim doğrudan pazarlamaya ihtiyacım yok.", "Doğrudan pazarlamayı denedim, ama işe yaramad1.” şeklindedir.

"Doğrudan pazarlamaya asla cevap vermem" diyen tüketiciler bile her ne kadar böyle söylemde de bulunsalar da, pek çoğu, ya internetten, televizyondan ya da telefon ile bir şekilde alışveriş ettikleri görülmektedir. "Perakende satış daha kolaydır" şeklinde düşünen bir üreticinin de tezi şu şekilde çürütülebilir; mağazaya sınırlı sayıda ürün konulabilir, ama doğrudan pazarlama da sınırsız ürün sunma şansınız vardır. Ayrıca geleneksel perakendecilik anlayışında ürün/hizmet önceden üretilmek durumundayken, doğrudan pazarlamada gerektiği kadar üretebilme şansı bulunmaktadır. Yine üretici "Yerel basına verdiğim ilanlar pekâlâ işe yarıyor. Benim doğrudan pazarlamaya ihtiyacım yok.” şeklinde düşünebilmektedir. Doğrudan pazarlamanın en önemli avantajı veri tabanı sayesinde tüketicilerinin gerçek tepkisini ölçebilmesidir. Böylece yatırımın geri dönüşüm oranı daha net olarak hesaplanabildiği için üreticinin bu söylemi de çürütülmektedir. "Doğrudan pazarlamayı denedim, ama işe yaramadı." söylemine sahip bir üreticinin ya da doğrudan pazarlama uygulayıcısının yapmış olduğu bir hata söz konusudur. Yani doğrudan pazarlamacı, tanıtımını ya yanlış insanlara yapmış olabilir, ya da yanlış bir yöntemle yapmış olabilir. (GELLER, 2004 s. 11-13)

Bu problemleri çözebilmek için de, Wunderman'ın doğrudan pazarlamacılara şu çözümleri önermektedir. 


\begin{tabular}{|c|c|}
\hline $\begin{array}{c}\text { Doğrudan Pazarlama } \\
\text { Uygulaması için adım adım öneriler }\end{array}$ & Açıklama \\
\hline $\begin{array}{c}\text { Doğrudan pazarlama bir taktik değil, } \\
\text { bir stratejidir. }\end{array}$ & $\begin{array}{l}\text { Doğrudan pazarlama kupon iliştirilmiş bir ilan, } \\
\text { ücretsiz aranabilen bir irtibat numarasını } \\
\text { duyuran bir reklam, mektup gönderme, } \\
\text { telefonla arama, promosyon ya da bir web } \\
\text { sitesi değildir. Doğrudan pazarlama değerli } \\
\text { müşterilere erişileceğine ve bu müşterilerin } \\
\text { elde tutulacağına dair verilen bir sözdür. }\end{array}$ \\
\hline $\begin{array}{c}\text { Ürün değil tüketici öncelikli } \\
\text { olmalıdır. }\end{array}$ & $\begin{array}{l}\text { Ürün, tüketicilerin her birine bir değer } \\
\text { sunmalıdır. Benzersiz olmalıdır. Örneğin } \\
\text { tüketicilerin " Buna ihtiyacım var" } \\
\text { dediklerinde üreticilerin onu üretebilmesidir. }\end{array}$ \\
\hline $\begin{array}{c}\text { Her bir tüketici ya da muhtemel } \\
\text { tüketici ile bir hedef kitleyle kurar } \\
\text { gibi iletişim kurulmalıdır. } \\
\end{array}$ & $\begin{array}{l}\text { Reklamlarda tüketiciye uygun olarak } \\
\text { hazırlanmalıdır. }\end{array}$ \\
\hline $\begin{array}{c}\text { “Neden yapayım?" sorusuna yanıt } \\
\text { verilmelidir. }\end{array}$ & $\begin{array}{l}\text { Tüketicilerin neden alayım ki gibi duygusal ve } \\
\text { rasyonel sorularının yanıtlarını ürün ve iletişim } \\
\text { olarak sürekli sunulmalıdır. }\end{array}$ \\
\hline $\begin{array}{l}\text { Reklam yalnızca tutumları değil } \\
\text { davranışları da değiş̧irmelidir. }\end{array}$ & $\begin{array}{l}\text { Tüketici tutumu, satın alma davranışını } \\
\text { desteklediği zaman bir anlam ifade etmektedir. } \\
\text { Firma ancak bu şekilde para kazanır. } \\
\text { Tüketicinin bir ürün hakkında bilgi danışması, } \\
\text { ürünü deneme, satın alma ve tekrar satın alma } \\
\text { gibi ölçülebilir davranışlardır. }\end{array}$ \\
\hline Reklam kâr getirmelidir. & $\begin{array}{l}\text { Reklamların sonuçlarının gittikçe kolay } \\
\text { ölçülebilir olması, reklamların aynı zamanda } \\
\text { kâr getiren yatırımlar olması gerekmektedir. }\end{array}$ \\
\hline Bir marka deneyimi yaratılmalıdır. & $\begin{array}{l}\text { Bir marka tüketicilerini memnun etmek } \\
\text { amacıyla, ambalajdan satış noktasına, satış } \\
\text { sonrası hizmetlerden iletişime kadar pek çok } \\
\text { deneyimi bir arada sunmalıdır. }\end{array}$ \\
\hline $\begin{array}{l}\text { Alıcı ile satıcı arasında bir ilişki } \\
\text { kurulmalıdır. }\end{array}$ & $\begin{array}{l}\text { Alıcı ve satıcı arasındaki ilişkiler zamanla } \\
\text { kurulmaktadır. Yani, alıcı ile satıcının ilk } \\
\text { karşılaştığı anda değil de, onlarla iletişim sıcak } \\
\text { tutulduğunda ve sürekli bir iletişim } \\
\text { sağlandığında iletişim kurulmalıdır. Böylece } \\
\text { kar elde etmekte mümkün olacaktır. }\end{array}$ \\
\hline $\begin{array}{l}\text { Her bir müşterinin bir ömür boyu } \\
\text { yaratabileceği dĕgeri öğrenilmeli ve } \\
\text { bu değere yatırım yapılmalıdır. }\end{array}$ & $\begin{array}{l}\text { Sadık bir müşterinin firmaya ömrü boyunca } \\
\text { kazandırabileceği değer hesaplanarak bu } \\
\text { değere karşılık ne kadar para harcanabileceği } \\
\text { hesaplanmalıdır. }\end{array}$ \\
\hline $\begin{array}{c}\text { 'Kuşkulular' 'muhtemel müşteriler' } \\
\text { değildir. }\end{array}$ & $\begin{array}{l}\text { Muhtemel müşteri ürünü ve hizmeti satın } \\
\text { almaya gönüllü, kuşkulu müşteri ise ürünü ve } \\
\text { hizmeti alması mümkün olabilen şeklinde } \\
\text { tanımlanabilmektedir. Muhtemel müşterilerle } \\
\text { ilişki kurmak satış maliyetleri azaltırken, } \\
\text { kuşkulu müşterilerle iletişim kurmak sadece } \\
\text { reklam maliyetlerini yükseltecektir. }\end{array}$ \\
\hline
\end{tabular}




\begin{tabular}{|c|c|}
\hline $\begin{array}{c}\text { Medya kullanimı bir temas } \\
\text { stratejisidir. }\end{array}$ & $\begin{array}{l}\text { Medya kullanımında sadece reklam vermek } \\
\text { yada tüketicinin reklamı görmesi önemli değil, } \\
\text { önemli olan reklamlardan ölçülebilir sonuçlar } \\
\text { elde etmektir. Her ne kadar reklamın etkinliği } \\
\text { erişim, sıklık gibi kavramlarla ölçülebilse de } \\
\text { artık, tüketicilere ne kadar temas ettiği ile } \\
\text { ölçülebilmektedir. }\end{array}$ \\
\hline Müșteriler üreticiye ulaşabilmelidir. & $\begin{array}{l}\text { Tüketicilere ne kadar fazla iletişim kanalıyla } \\
\text { ulaşılabiliyorsa, ki bu iletşşim kanalları; } \\
\text { veritabanı, enformasyon ve hizmet kaynağ1 } \\
\text { olabilmeyle iliskilidir, müsterilerde neye } \\
\text { ihtiyaçları olduğunu rahatlıkla firmaya } \\
\text { iletebilirler. }\end{array}$ \\
\hline $\begin{array}{c}\text { Tüketici ile interaktif bir iletişim } \\
\text { kurulmalıdır. }\end{array}$ & 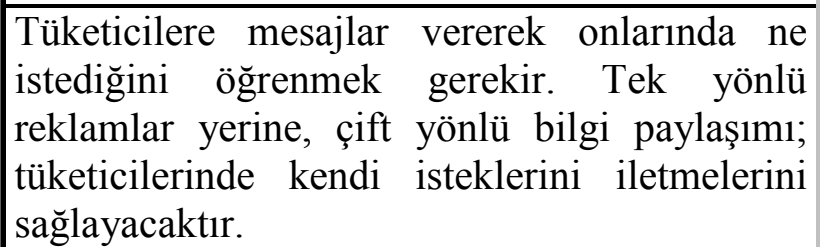 \\
\hline $\begin{array}{l}\text { Tüketicinin ne zaman sattn alacăğ } \\
\text { sorusu doğru yanttlanmalddtr. }\end{array}$ & $\begin{array}{l}\text { Tüketicinin bir ürünü veya hizmeti ne zaman } \\
\text { satın almak isteyeceği, tüketiciye doğru sorular } \\
\text { sorarak bulunmalıdır. }\end{array}$ \\
\hline $\begin{array}{c}\text { Bir ürünü satmanın yanı stra } \\
\text { bilgilendirici bir reklam 'içeriği' } \\
\text { sunulmalıdır. }\end{array}$ & $\begin{array}{l}\text { Reklamların amaçlarından biri de bilgi } \\
\text { vermektir. Hem ürün/hizmetle ilgili bilgi verir, } \\
\text { hem de tüketicinin bu ürünü neden satın almas1 } \\
\text { gerektiği ile ilgili. Böylece, reklamın amac1 } \\
\text { sadece ürünü/hizmeti satmaktan öteye } \\
\text { gitmektedir. }\end{array}$ \\
\hline $\begin{array}{l}\text { Sadık müsşteri olabilecek müsssteriler } \\
\text { kazanılmaya çalsşılmalıdır. }\end{array}$ & $\begin{array}{l}\text { Yapilan tutundurma faaliyetlerine yanıt veren, } \\
\text { sadece promosyonları tercih eden tüketiciler } \\
\text { yerine, ürünün/hizmetin kendisini isteyecek } \\
\text { doğru müşteriler bulup onlar ikna edilmelidir. }\end{array}$ \\
\hline $\begin{array}{c}\text { Sadakat süreklilik gerektiren bir } \\
\text { programdır. }\end{array}$ & $\begin{array}{l}\text { Tam anlamiyla tatmin edilmiş bir müșsterinin } \\
\text { bir markay1 birakıp gitmesi pek mümkün } \\
\text { değildir. Sürekli iliskkiler kurabilmek amaciyla } \\
\text { da, bu müşerileri dönem dönem } \\
\text { ödüllendirmek gerekir. }\end{array}$ \\
\hline $\begin{array}{c}\text { Sadık müssteri payı kazanç } \\
\text { yaratmaktadır. }\end{array}$ & $\begin{array}{l}\text { Bir firmanın sadık müssterisi ne kadar fazla ise } \\
\text { kazancı o kadar fazla olacaktır. Cünkü yeni bir } \\
\text { müsteri yaratmak maliyet gerektirir. Oysa eski } \\
\text { müstserileri elinde tutmak daha az maliyetli ve } \\
\text { daha karlı bir yöntemdir. }\end{array}$ \\
\hline Firmanin "bilgisi" hazinesidir. & $\begin{array}{l}\text { Veri masraf, bilgi hazinedir. Elde edilen } \\
\text { verilerin bilgiye dönüştürülmesi sonucunda } \\
\text { ancak kar elde edilebilir. }\end{array}$ \\
\hline
\end{tabular}

Tablo 3: Doğrudan Pazarlamanın Uygulanması için Öneriler

Kaynak: BAYSAL Aşkın Doğrudan Pazarlamanın Kurucusu: Lestern Wunderman, İstanbul : MediaCat Yayınları, 2006. - İz Bırakanlar Serisi 8. 


\subsection{Doğrudan Pazarlamanın Bileşenleri}

Doğrudan pazarlamanın bileşenleri şunlardır:

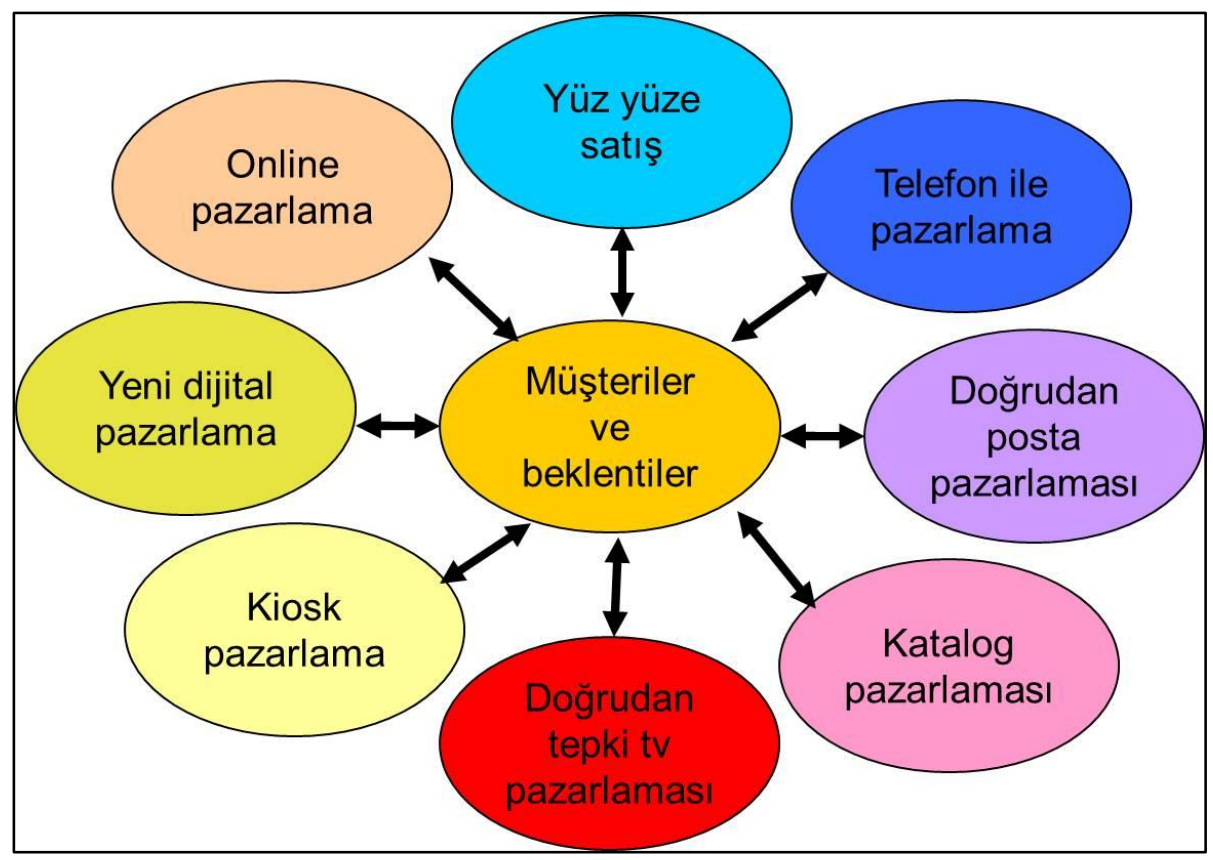

Şekil 3: Doğrudan Pazarlamanın İletişim Şekilleri

Kaynak: KOTLER Philip ve AMSTRONG Gary Principles of Marketing, Prentice Hall College Div,

\subsubsection{Doğrudan Satış} 2005. - Cilt 11th. Edition.

Doğrudan pazarlamanın bilinen en eski şekli doğrudan satıştır. Literatürde yüzyüze satış ya da kişisel satış (KOTLER, et al., 2005 s. 461) olarak da rastlayabileceğimiz bu kavramın aynı zamanda, doğrudan pazarlama kavramı ile karıştırıldığına doğrudan pazarlamayı tanımlarken değinmiştik.

Doğrudan satış kavramının literatürde çeşitli tanımlarına rastlamamız mümkündür. Örneğin Lazer ve Layton'a göre doğrudan satış, "satıcı ve alıcı arasında doğrudan bir iletişimi sağlayan ve pek çok ürün ve hizmetin pazarlanmasında yararlanılan bir doğrudan pazarlama aracıdır." (LAZER, et al., 1999 s. 343) Doğrudan satışın diğer bir tanımı ise, "satış personelinin potansiyel alıcının satın alma gereksinimini, kendi firmasının ürün ya da hizmetine yönlendirerek gerçekleştirdiği iletişim süreci olarak tanımlanabilir. Doğrudan satışın en önemli özelliği, iletişim sürecinin yüz yüze gerçekleştirilmesidir.” (PELTEKOĞLU, 2001 s. 22) şeklindedir.

Doğrudan satış, satışın da en eski şeklidir ve satış, satış danışmanı kanalıyla gerçekleştirilir. Bu nedenle doğrudan satış; "satış amacıyla, satış danışmanı ile alıcının 
karşı karşıya gelmesi ve alıcıya malı sözlü olarak tanıtması, kısaca alıcı ile satıcı arasındaki karşı1ıklı bir diyalogdur." şeklinde de tanımlanabilmektedir. (TOKOL, 1996 s. 148)

Hedef kitlelerle doğrudan iletişim sağlaması ve geri bildirimin kısa sürede alınması nedeniyle, pazarlama iletişiminde de doğrudan satış önemli bir rol oynamaktadır. (PELTEKOĞLU, 2001 s. 22)

Doğrudan satışta kullanılan yöntemlerden biri kapıdan kapıya satış yöntemidir. Kapıdan kapıya satışı, satış elemanlarının tüketicinin ev ve işyerlerini dolaşarak yanlarında satışını yapmak üzere getirdikleri ürünleri satarak hemen teslimini veya sipariş alıp ürünün daha sonra teslimini içeren bir satış yöntemi olarak da tanımlayabiliriz. (KARTAL, 2007 s. 16)

Doğrudan satışın başlıca özellikleri şunlardır: (AKAT, 2001 s. 178)

Kişisel karşılaşmada "satışçı" ile alıcı arasında direkt ve canlı ilişki kurulur. Karşılıklı istek ve ihtiyaçları yakından izleme esnekliği sağlar.

Dostluk ilişkileri geliştirme söz konusu olabilir. Bu sayede iki taraf arasında sürekli alım/satım ortamı doğabilir.

Dinleme ve karşılık verme zorunluluğu olması çift yönlü iletişim sağlar. Reklamın tersine, alıcı malı almasa bile, bazen nezaketen de olsa dinleme gereği duyar.

Satışçının gerekli bilgileri toplaması sonucunda; satıcı firma satışçılar yardımıyla direkt olarak tüketicilerin istek ve ihtiyaçları hakkında bilgi sahibi olur.

$\mathrm{Bu}$ açıklamalar 1şı̆̆ında doğrudan satışın genel amaçları şu şekilde özetlenebilir: (ODABAŞI, et al., 2002 s. 171)

Müşteriyi ikna ederek satışı gerçekleştirmek

İşletmeye pazar, rakipler ve müşteriler hakkındaki bilgileri doğru ve zamanında ulaştırmak

Müşterilere uygun seviyede hizmetlerin gitmesini sağlamak

Müşteri tatminin sağlamak ve geliştirmek 


\subsubsection{Online Pazarlama}

Teknolojinin günümüz dünyasına kazandırdığı hizmetlerden biri olan internet, getirdiği hızlı erişim ve esnek kullanılabilirlik olanakları sayesinde pek çok alanda olduğu gibi, pazarlama alanında da kendine önemli bir yer edinmiştir. İnternet üzerinden yapılan pazarlama çabalarına online pazarlama ya da diğer bir ismiyle elektronik pazarlama denilmektedir. (KOCABAŞ, 2005 s. 119) Bu bağlamda online pazarlamanın çeşitli tanımlarını incelemek gerekir.

Online pazarlamada üreticinin sunduğu ürün ve hizmetler bilgisayar ortamına aktarılarak kataloglar yaratır. Yani bu yöntemle tüketici bir ürün satın almak istediğinde evindeki bilgisayar ile, bilgisayar ortamına aktarılmış katalogdan tüm markaları görebilir, bu markaları karşılaştırabilir, sonra da satın alabilir. (KOTLER, et al., 1996 s. 479)

Online pazarlama; pazarlama hedeflerine ulaşmak için internet ve internete ilişkin dijital teknolojilerin kullanımıdır. Online pazarlamada amaç mal satmaktır. Yani pazarlamanın dişarıda yaptığı işi, internet üzerinden yapmak demektir. Hatta online pazarlamada daha yüksek sonuçlar elde edilmekte ve pazarlama işlemleri daha hızla gerçekleşmektedir. (KOCABAŞ, 2005 s. 119)

Online pazarlama; ürünü tanıtmada ve pazarlamada kullanılmaktadır. Tanıtım, internetin sağladığı imkânlarla ucuz ve çok etkilidir. Müşteri interaktif olarak ürün hakkında bilgi isteyebilmektedir. Posta, telefon, yazışma gibi iletişimden doğabilecek masraflar sifir veya sifira yakındır. E-mail, arama robotları, promosyon, banner reklamları ve ortaklık programları internet pazarlamasında kullanılan araçlardan bir kaçıdır. Bu sayılar her geçen gün artmaktadır. (ÖNCÜ, 2002, s. 13)

İnternet sayesinde doğrudan pazarlama faaliyetlerinde web sayesinde olas1 müşterinin ismi, adresi, tüketim alışkanlıkları, yani olası müşteriye yönelik kişisel bilgiler elde edilebilmektedir. Yeni şifreleme teknolojisi sayesinde artık güvenli bir şekilde kredi kartı kullanarak alışveriş yapmak mümkündür. (PIRNAR, 2010 s. 189)

E-pazarlamanın gelişim seyrini Zyman ve Miller üç safhada incelemişlerdir: (ZYMAN, et al., 2003 s. 36-40) 
1.Safha e-pazarlamanın ilk ortaya çıktığı dönemdir. Bu dönemde Yahoo, AOL, Amazon gibi birkaç ticari site ortaya çıkmış, rakiplerin azlığı nedeniyle de üstünlük sağlamışlardır. E-pazarlamanın birinci safhasında iletişim stratejisi olarak ağızdan ağıza iletişim modeli etkin bir rol oynamıştır.

2.Safha 1996-1999 yıllarını kapsayan dönemdir. Bu dönemde ilk safhada yer alan internet siteleri yaygınlaştırılmış ve kaçınılmaz hale getirilmiştir. Örneğin Amerika'daki herkesin AOL kullanması gerektiği konusunda derin bir kabul yaratılmaya çalışılmıştır. Bu da o markanın tercih edilmesi konusunda bir kaçınılmazlık yaratmıştır. Bu safhayı olumsuz etkileyen, hedef kitle ile ilgili etkenler saptanmış, buna rağmen de rekabet artmış ve mesajlar hedef tüketicilere daha hızlı ve etkili bir biçimde ulaştırılması gerekliliği ortaya çıkmıştır.

3.Safha pazarlamaya stratejik olarak yaklaşmanın önemini ortaya çıkarmıştır. Günümüzde pazarlama altında ele alınan her karar, her eylem planlamadır. Yine günümüzde pazarlamanın yaşadığg, dönüşümde yeni pazarlama yöntemlerinin de ortaya çıkmasıyla reklamın amaca yönelik ele alınmasının önemi anlaşıııış, maliyetleri minimize ederek nasıl karlı olunabileceği üzerinde durulmaktadır. Dolayısıyla bu dönemde elektronik pazarlama kavramı internet üzerinden satış yapmaya odaklanmıştır.

$\mathrm{Bu}$ aşamada online pazarlamada kullanılan başlıca yöntemlere bakmak yerinde olacaktır.

\section{Videotext:}

Online alışverişin bugünkü başlıca şekli internet ve video text aracılığıyla olmaktadır. Fakat internet sınır tanımayan gelişimi ile elektronik alışverişin en önemli aracı olmuştur.

Online pazarlamada kullanılan yöntemlerden biri video textir. Videotext televizyondaki teletext sistemine benzer bir sistem olmakla beraber teletextten fark1, iki taraflı etkileşimi olmasıdır. (HASPOLAT, 1998 s. 34) Tüketicilerin istedikleri zamanlarda, bulundukları yerden istedikleri zaman internet veya videotex'e bağlanabilmeleri ve alışveriş edebilme imkanlarının olması (KOTLER, 2000 s. 665) online pazarlamanın en temel avantajı olarak kabul edilmektedir. 


\section{E-posta yöntemi ile pazarlama:}

Online pazarlamada kullanılan yöntemlerden diğeri, elektronik posta ile pazarlamadir.

E- Posta Pazarlaması (E- Mail Marketing), pazarlama faaliyetlerinin daha etkin verimli, hızlı ve kapsamlı bir şekilde gerçekleştirilmesi amacıyla, işletmelerin internet ortamından yararlanarak iletişim, tanıtım satış ve pazarlama faaliyetlerinde e-posta yöntemini kullanmalarını ifade etmektedir (DENIZ, 2002 s. 3).

Rizzi (2001), elektronik posta ile pazarlamada son jenerasyonun, doğru kişiye, doğru zamanda, doğru e-posta mesajının gönderimi yaklaşımını benimsediğini ifade etmektedir. Toparlayacı bir tanım olarak Haşıloğlu, "Elektronik posta ile pazarlama , elektronik posta sisteminin diğer internet araçları ile bir bütün olarak yürütülen, müşterinin izni ve kontrolünde olan, işletme tarafından geri dönüşleri ölçülebilen ve aşamalardan meydana gelen bir pazarlama sürecidir." şeklinde ifade etmektedir. (HAŞILOĞLU, 2010 s. 62)

E-posta ile tanıtımda kişilere e-posta yoluyla çeşitli tanıtım, promosyon mesajları gönderilmekte, indirim veya çeşitli firsatlardan yararlanma şansları sunulmaktadır. (ERDEM, 2010 s. 82)

Dünyada e-posta kullanımı ticari açıdan gittikçe yaygınlaşmaktadır. Bunun nedenleri olarak, kullanım kolaylığı, düşük maliyet, esneklik, mesajın kişiselleştirilebilmesi ve başarılı sonuçlara ulaşmadaki kolaylık olarak sayılabilmektedir. (PIRNAR, 2010 s. 154)

Elektronik posta ile pazarlamada önemli olan nokta maximum sayıda müşterinin mesajları görmesidir. Ancak bir kişinin e-posta adresini bilmek pazarlama amaçlı e-posta gönderebilmek için yeterli değildir. (UYDACI, 2004 s. 81)

Pek çok işletme ürünlerini tanıtmak, satış fırsatlarını haber vermek gibi nedenlerle e-postadan yararlanmaktadır. İşletmeler e-posta aracıllı̆g ile mevcut ve potansiyel müşterilerine faaliyetleri ile ilgili her türlü bilgiyi, haberi, yeniliği, öneriyi hızla iletip geri bildirim alabilmektedirler. Bu açıdan e-posta, doğrudan pazarlamanın geleceği olarak nitelendirilmektedir. E-posta pazarlama faaliyetlerinin iki türü vardır. 
Bunlardan biri izinli e-posta pazarlama faaliyetleri iken, diğeri de izinsiz e-posta pazarlama faaliyetleridir (DENIZ, 2002 s. 3).

E-postayla tanıtım da, kişilerin e-posta adreslerine kişisel bilgisi dahilinde ve hangi amaç için kullanacağının belirtilmesi şartıyla ulaşmak etik ve tercih edilen olacaktır. (ERDEM, 2010 s. 82)

Eğer e-posta ile pazarlama müşterinin izni ile yapılıyorsa yüksek geri dönüş oranları sağlarken, izinsiz gönderilen e-postalar, çoğunlukla müşterinin tepkisine neden olmakta ve çoğunlukla okunmadan silinerek, beklediği yarardan çok zarar vermektedir (DENIZ, 2002 s. 3).

\subsubsection{Yeni Dijital Doğrudan Pazarlama}

Doğrudan pazarlamanın elektronik iletişim araçlarıyla, alıcılara ulaşmasına yeni dijital doğrudan pazarlama denir (What is com). Dijital pazarlama televizyon, radio, internet, cep telefonu, sosyal medya pazarlaması ve diğer dijital medya araçlarını kullanır (Vikipedia Sözlük).

Bunlardan yalnızca birini ve en önemlisini açıklamak yeterli olacaktır (KOTLER, et al., 2008 s. 491-493).

Cep telefonuyla pazarlama: Gelecekte en önemli doğrudan pazarlama çeşidi olacak olan cep telefonuyla pazarlama yönteminde, cep telefonundan televizyon izleme, internete girebilme ve GPS sistemiyle yön bulma işlevlerini firmalar, reklam kampanyaları için kullanmaktadırlar. Örneğin, Mc Donalds'ın Big Mac paketlerine koyduğu bir kod sayesinde, kişisel bilgilerle birlikte gönderilen bir SMS karşılığında yapmış olduğu kampanya ile firma bir veritabanı oluşturmakta ve bu veritabanını gelecekteki kampanyalarını duyurabilmek için kullanmaktadır. Diğer bir örnek ise Turkcell'in yapmış olduğu kampanyadan verilebilir. Alışveriş merkezine girildiğinde A mağazasının reklamı cep telefonuna gelmektedir.

Cep telefonu özelliği olarak Podcast'lerden ve Vodcast'lerden bahsetmek gerekmektedir. Ipod'lara internete bağlanarak yüklenebilen müzik ve video yükleyebilme özelliği sayesinde reklam ve bilgi materyalleri de yüklenebilmektedir. Örneğin Kraft'1n yemek tarifleri ve Disney'in haftalık podcast sunumları gibi. 
Interaktif televizyon yayını sayesinde, kumandanın tek bir tuşu ile alışveriş edebilme, ya da örneğin filmlerde farklı film sonları izleyebilme özelliği ya da istenilen reklamı seçip izleyebilme gibi ayrıcalıklara sahip olunabilmektedir. Bu yöntemde evdeki televizyon sisteminden internete bağlanılarak interaktif televizyon ile birleştirilmektedir.

\subsubsection{Telefon ile Pazarlama}

Telefonla pazarlama, önceden belirlenen müşterilerle telefon aracilığıyla satış amaçlı iletişim kurma tekniğidir (ODABAŞI, et al., 2002 s. 315) ve doğrudan pazarlamanın çeşitlerinden biridir.

Stone ve Wyman'a göre telefon ile pazarlama, işletme verimliliğine katkıda bulunmak, satışları arttırmak, şimdiki tüketiciler ve potansiyel müşteriler ile iletişim kurabilmek için, işletmelerin kişisel satı̧ ile destekleyerek, tele iletişim ve bilgi sistemlerini kullanmalarıdır. (STONE, et al., 1992 s. 3)

Telefonla pazarlama aynı zamanda pek çok doğrudan pazarlama faaliyetinde iletişim aracı olarak kullanılmaktadır. Telefon ile pazarlamanın iki şekli vardır. Biri outbound denilen dişarı arama yöntemidir. Burada pazarlamacılar, işletmelere ve tüketicilerine doğrudan satış yapabilmektedirler. Diğeri ise inbound denilen gelen aramayı karşılama yöntemidir. Burada tüketici televizyondan, radyodan, kataloglardan veya doğrudan postalamadan gördükleri ücretsiz 800 'lü numaraları arayarak sipariş verirler. (KOTLER, et al., 1996 s. 478) Inbound da amaç tüketicinin verdiği tepkiyi karşılamaktır.

Telefonla pazarlamanın kullanıldığı diğer pazarlama faaliyetleri arasında; ürün geliştirilmesi pazarlama stratejilerinin detaylarının belirlenmesi, rekabet hakkında bilgi edinilmesi, firma veya marka hakkındaki olumsuz algılamanın olumlu yönde değiştirilmesi, istenilen miktarda sipariş alınması, hizmet ve parça sorunlarının çözülmesi, satış sonrası hizmetlerin gerçekleştirilmesi, aboneliklerin yenilenmesi, araştırma için bilgi sağlanması bulunmaktadır. Ayrıca reklâm ve tutundurmaları takip etme kayıtları güncelleştirme, iyi müşteri ilişkilerini sağlama ve koruma yeni müşteriler bulma alanlarında da telefon ile pazarlamada olumlu sonuçlar vermektedir. (PIRNAR, 2010 s. 113) 
Firmaların telefonla pazarlama yöntemini kullanma nedenlerini şu şekilde özetleyebiliriz;

Yeni müşteri bulma,

Satış maliyetlerini azaltma,

Mevcut müşterilerle ilişkilerini daha iyi hale getirebilme

Müşteri ilişkilerini ve/veya teknik desteği geliştirebilme

Gelen siparişleri ve bilgi alma isteklerini elde tutma gibi sebeplerinden ötürü firmalar telefonla pazarlama yöntemini kullanmaktadırlar. (ELLEN, 2003 s. 21)

\subsubsection{Doğrudan Posta}

Hedef kitle üzerinde doğrudan tepki sağlanmaya çalışıldığında en temel yöntemlerden biri adreslere yapılan postalamalardır. Doğrudan pazarlamada kullanılan en eski yöntemlerden biri olan doğrudan postalamanın doğrudan pazarlama faaliyetlerindeki yeri çok önemlidir. Kapsadığı önemli yer nedeniyle literatürde kimi zaman doğrudan pazarlama yerine kısaca doğrudan postalama ifadesinin kullanıldığ1 durumlara rastlanılmaktadır. (PIRNAR, 2010 s. 146)

Doğrudan postalama yönetimi, doğrudan ve bire-bir iletişime çok uygundur. $\mathrm{Bu}$ yöntem büyük pazar seçimlerine, kişiselleştirmeye, esnekliğe izin verir. Aynı zamanda sonuçların kolay ölçülmesini de sağlar. (KOTLER, et al., 2005)

Doğrudan posta; hedef kitleye bizzat başvurmak amacıyla kişisel olarak yazılan mektuplar, broşürler, küçük el kitapları, kataloglar, sirküler veya el ilanlarını kullanan iletişim aracıdır. (PIRNAR, 2010 s. 146)

Aynı zamanda doğrudan posta hedeflenen gruba, posta aracılığıyla yollanan bir tanıtım mesajını içeren satış teklifidir. Bu sadece tek sayfalık bir mektup olabildiğgi gibi birçok sayfalardan oluşan bir mektup, tanıtım katalogları, broşürler ya da daha fazla ilgilenenler için sipariş kartı şeklinde olabilir. (KOÇKAYA, 2006 s. 22)

Toparlayıcı bir tanım olarak doğrudan posta, çok geniş bir tüketici kitlesine, yerine göre çok geniş bir ürün kategorisiyle, doğrudan ulaşılarak, ürünün sipariş ve teslimatının yerinde gerçekleştirildiği bir pazarlama yöntemidir. (KARTAL, 2007 s. 33)

$\mathrm{Bu}$ yöntemin amac1, dar bir hedef kitleyi, hedef kitlenin özel ihtiyaçlarına uyacak şekilde tasarlanan, kişiselleştirilebilir mesajlarla çekebilme de etkili olmasıdır. 
(ODABAŞI, et al., 2002) Yani, postalanan mektup veya bir tür tanıtım broşürü yoluyla müşteriden bir cevap alınır ve bu cevap kolaylıkla ölçülebilir. Cevap oranını yükseltmenin bir yolu doğru hedeflenmiş posta listesidir. Hedeflenmiş listeler potansiyel ve mevcut müşterilerle bireysel ilişkiler kurmaya olanak sağlar. (KOÇKAYA, 2006 s. 24)

Bir doğrudan posta kampanyasının etkili olabilmesi için detaylı ve kaliteli bir postalama listesinin hazırlanması gerekir. Müşteri listeleri dergi, katalog veya çeşitli derneklerin üye listelerinden veya anketler aracılığı ile derlenmektedir. (ODABAŞI, 2004 s. 6-7)

$\mathrm{Bu}$ hizmeti veren kuruluşlar da bulunmaktadır. Bu kuruluşlar müşteri listeleri hazırlayıp bunları kiralama ve satma yöntemi ile kullanıma sunmaktadırlar. (JOBBER, 1998 s. 395)

Doğrudan yapılan postalamalarda satış elemanı kullanma gereği olmadan bir ürünün ne olduğu ve nasıl kullanılabileceği ile ilgili mesajlar verebilmektedir. Telefonla yapılan pazarlamaya göre görsel etkilenmeyi de içerdiğinden özellikle karmaşık ve çok seçenekli ürünler için çok daha etkilidir. (TAPAN, 1997 s. 346-347)

Bazı kaynaklara göre (PIRNAR, 2010 s. 153) (ODABAŞI, et al., 2002 s. 312) elektronik posta ile pazarlama yöntemi doğrudan postalamanın kullandığı yöntemlerden biri olarak kabul edilir. Elektronik postanın mantığg da doğrudan postalama yöntemi ile aynı olduğu için, doğrudan postalamanın elektronik ortamdaki hızlı ve güvenli mektup gönderme ve haberleşme isteğidir.

Doğrudan postalamanın kullandığı yöntemlerden biri olarak kabul edilen diğer bir metod ise, katalog ile pazarlamadır. Katalog ile pazarlama metodunda kataloglar müşterilere postalanır veya mağazalarda isteyenlere teslim edilir. Siparişler kataloglardan kesilen veya insert sipariş fişi doldurularak mektup veya telefonla verilir. Bu özelliklerinden ötürü doğrudan postalama ile içi içe geçmiştir. (TEK, 1997 s. 605) Hatta ilk doğrudan posta faaliyetlerinin ABD'de 19.yy. sonunda, başlangıçta ulaşımı zor ve kırsal alanlara hitap etmek için gönderilen kataloglar ile ortaya çıktığı bilinmektedir. 1872 yılında ilk posta ile kataloğunu gönderen Montgomery Ward, böylece modern anlamda posta ile satışı başlatan kişi olmuştur. (TEK, 1997 s. 604) 
Ürün ya da hizmetin görsel öğelerle desteklenmesini sağlayan bir diğer doğrudan posta yöntemi ise broşürlerdir. (GELLER, 2004 s. 94) Broşür ya da insert olarak bilinen kavram, aslında daha çok fiyat indirimlerini duyurmada kullanılan basılı bir medya aracıdır. Fakat posta kutularına bırakılarak tüketicilere ulaştırılması onu doğrudan postalamanın içerisinde değerlendirilmesini sağlamaktadır. (TIĞLI, et al., 2003 s. 122)

Doğrudan posta yöntemi maliyetli bir yöntem olmasına rağmen doğrudan pazarlamanın en çok kullanılan iletişim şekli olmasının nedenini avantajlarını inceleyerek anlayabiliriz; (GELLER, 2004 s. 70-72)

Acil olduğu duygusunu uyandırma: Doğrudan postanın müşteriye kişisel olarak gönderilmesi, kişi de gönderinin hemen açılması hissini uyandırmaktadır. Böylece en hızlı tepki alabilme sağlanır.

Potansiyel müşterilere kolay ulaşabilme: satış yaparken karşılaşılan iki tip potansiyel müşteri vardır; nitelikli ve niteliksiz potansiyel müşteri. Niteliksiz potansiyel müşteri tesadüfen ulaşılan müşteri tipi iken, nitelikli potansiyel müşteri ürüne ilgisi olduğu ve onu alabileceği bilinen müşteridir. Doğrudan pazarlamanın genel olarak amacı "nokta pazarlama" yapabilmek olduğu için, doğrudan posta yönteminde liste yoluyla belirlenen kriterlere uygun seçilen müşterilere postalama yapılması bu müşterilerin satın alma olasılığını da yükseltmektedir.

Tekrarlı alıcılar kazanabilme: Kişisel olarak gönderilen bir postalama yönteminden ürün ya da hizmeti satın alan müşteriler, bu davranışı tekrar edebilme özelliğine sahiptir.

Hayatı kolaylaştırma: tüketicinin olduğu yerde ürünün tanıtılması, satıcının zorlaması olmadan ürününü seçmesi, sipariş vermesi ve bu siparişlerin tüketicinin olduğu yere teslim edilmesi en önemli üstün özelliklerindendir. Ayrıca bu yöntemin sunduğu ek hizmetler de (iadelerin kabulü, ürün değiştirme gibi) üstün özellikleri olarak siralanabilir. (NASH, 1982 s. 103)

\subsubsection{Katalogla Pazarlama}

Katalogla pazarlama doğrudan pazarlamanın uygulamada hemen hemen kendisiyle özdeşleşmiş bir yönelimidir. Aynı zamanda en eski yönelimlerindendir. Doğrudan pazarlamanın tarihsel gelişimden bahsederken, ilk olarak 1400'lü yıllardaki Venedik’te dağıtılan kataloglardan söz etmiştik. 
Kataloglar, işletmelerin satışa sundukları ürün ve hizmetlerin resimlerini de basabildikleri, satışa sunulan ürün hakkında detaylı bilgi sağlayan ufak kitapçıklardır. Renkli, siyah beyaz basılan, kaliteli kâğıt kullanan, pek çok ürünü bünyesinde barındıran, belirli zaman aralıklarıyla çıkan çeşitleri bulunmaktadır. (PIRNAR, $2010 \mathrm{~s}$. 149)

Katalogla pazarlama yapan işletme kendi amaçlarına ve hedef kitlesinin gereksinimlerine uygun katoloğu hazırlar; önceden belirlediği isim ve adreslere postalar. Katalog ürünü, ürünün fiyatını, reklamını, katalog firmasının imajını tüketiciye taşır ve doğrudan sipariş ister. Alıcı katalogda beğendiği ürünlerin siparişini verir. Telefon veya mektupla alınan sipariş tüketicinin adresine teslim edilir. (GÜRAĞAÇ, 2006 s. 23-24)

Katalog perakendeciliği özellikle ABD'de büyük bir ticaret olarak tanımlanmaktadır. Aslında katalog ile satış yapan bu kurumların hiçbir mağazası ve bayii ağı yoktur ve sadece bir depoya stokladığı ürünlerini kataloglar ile tüketiciye ulaştırmaktadır. (Katalogla Pazarlama, 2010)

Firmalar sipariş verme ihtimali yüksek olan müşterilerine katalog gönderirler. Katalogla pazarlama oldukça yoğun bir şekilde tüm dünyada kullanılmaktadır. Katalogla pazarlamada kataloğun müşteriye ulaşmasındaki tek araç, doğru isim ve adres olduğu için müşteri listelerinin doğruluğu ve güncelliği son derece önemlidir. Farklı bir sunum yapabilmek amaciyla bazı firmalar kataloglarına telefon numaraları ve hediyeler eklerler. Kimi firmalarda video katalog kullanmakta veya internet ortamından sunum yapmaktadırlar. Katalogla pazarlama sadece dar bir coğrafya içine sığdırılmamakta ülkeler hatta kıtalar arası alış verişe konu olabilmektedir. (KOÇKAYA, 2006 s. 25)

Katalog diğer tanıtma araçları ile birlikte kullanılabilmektedir. Çünkü katalog ile alışverişte müşteriler zaman ve mekan olarak kolaylık yaşamaktadırlar. Etkili bir katalog çalışması yapabilmek için, ürünlerin sipariş aşamasından sonra müşterilere mümkün olduğunca hızlı ulaştırılması gerekmektedir. Ayrıca veri tabanında yer alan kişisel bilgiler, özel günler ve ilgi alanları müşterilere katalog gönderilirken göz önüne alınmalı ve kataloglar buna göre kişiselleştirilmelidir. (PIRNAR, 2010 s. 168-172) 


\subsubsection{Kiosk ile Pazarlama}

Genel bir tanıma göre ise kiosklar "kabin içine gizlenmiş bir bilgisayar, dokunmatik bir ekrandan oluşan, tanıtım, reklâm, bilgilendirme, yönlendirme amaçlı kullanılan yüzyılın gelişmiş interaktif tanıtım araçlarıdır.” (Focus, 2010)

Kiosk sistemlerinin en önemli özelliklerini şu şekilde sıralamak mümkündür; (Gonca Grubu)

Geliştirilen yazılım avantajı sayesinde kiosklar hedef kitleye iletilmek istenen bilgileri, video-foto olarak görsel destekli ve müzik, tekst olarak aktarabilme imkânı verir.

Kiosk sistemi destekleyen, dokunmatik ekranı ve ekrana dokunularak kullanılan klavye yazılımı sayesinde kolay kullanım avantajı sağlar ve sorgulanabilecek veya girilebilecek her türlü bilgi girişine açıktır.

Kiosklar üzerinde bulunan barkot okuyucu ile ürün, fiyat tanıma ve kiosk üzerinden kredi kartı ödeme ile kasiyersiz hızlı ürün satış kasası oluşturma özelliğine sahip olabilir.

Kiosklar üzerindeki manyetik ve smart kart okuyucu üniteleri ile bankacılık, loyalty projeleri, güvenlik, kimlik tanıma, e-ticaret, ticketing uygulamalarında kullanılır.

Kiosk sistem, dokunmatik ekranı ve ekrandan kullanılan klavyesi sayesinde, internet ve e-mail bağlantısı sağlar. İnternet üzerinden hedef kitleye ürün ve hizmetler sunulur.

Kiosk'a yerleştirilen Call Center sistemi ile ekrandaki telefon numarasına dokunularak müşteri hizmetleri interaktif olarak verilebilmektedir.(CRM desteği)

Kiosk sisteminin yazılımı uzun vadeli planlanarak, sonradan girilebilecek her türlü bilgi girişine açıktır. 


\subsubsection{Doğrudan Tepki Televizyon Pazarlaması}

DRTV, yani direct response marketing veya direct response television marketing olarak açıklanan bu kavram, doğrudan pazarlamanın televizyon aracılığıyla yapılmasıdır. (KOTLER, et al., 2005 s. 512) Ayrıca, Türkçe'ye doğrudan tepki pazarlaması olarak geçmiştir. (KAYAR, 2010 s. 255)

1970’li ve 1980'li y1llarda pazarlamacılar, yeni bir medya olmamasına rağmen, doğrudan tepki televizyon reklamlarının çok kullanışlı olduğunu keşfetmişlerdir. Bu reklamların ölçümü kolay olduğu için, doğrudan tepki kampanyalarını, firmalar aldıkları tepkiye göre düzenleyebilmekte ve normal reklama kıyasla daha fazla satış yapabilmektedirler. (McDonald, 1997 s. 264)

Doğrudan tepki televizyon pazarlaması ile doğrudan pazarlama bazı kaynaklara göre aynı anlamda anılmaktadır. Örneğin her ikisi içinde; “Ölçülebilir bir tepkiye ya da işlem hareketine ulaşmak için, bir veya birden fazla reklam medyasının kullanıldığg, pazarlamada etkileşimli bir sistem" tanımı yapılabilmektedir. (JAMES, et al., 1990 s. 24). Buradan da anlaşılabileceği gibi doğrudan tepki televizyon pazarlaması temelde, doğrudan pazarlama ile aynı hedeflere sahiptir. Yani aynı sonuçları araştırır. Geleneksel televizyon reklamlarından ise tamamen farklıdır. Doğrudan tepki televizyon pazarlaması sadece anlık tepkilerde telefonla aranmak için değildir, ama tepkiyi ölçmenin bir yoludur. (BUSH, et al., 1990 s. 7). Ayrıca doğrudan pazarlama da firma müşterisine ulaşırken burada müşteri firmaya ulaşmaktadır. (KAYAR, 2010 s. 255)

Doğrudan pazarlamacılar kaç insanın onların reklamlarını araştırdıklarını, tepki verdiklerini, her süreç için insanların ne kadar harcama yaptıklarını bilmektedirler. Doğrudan tepki televizyon reklamlarında ki öngörülen tepkiler, doğrudan pazarlamanın, stratejik, finansal ve örgütsel planının bir parçasıdır. (BAUER, 1987 s. 39)

Infomercial reklam terimi de doğrudan tepki televizyon reklamlarının yerine kullanılmaktadır. Özellikle süre açısından bu benzetme yapılmaktadır. Doğrudan tepki televizyon reklamları 60 saniye ile 120 saniye arasında gösterilmektedir. Oysa infomercial reklamlar 3 dakikadan 2 saate kadar uzun formatta olabilmektedir. (Vikepedia Sözlük, 2011)

Doğrudan pazarlamanın özellikleri: $\mathrm{Bu}$ aşamada doğrudan tepki pazarlamasının özelliklerine değinmekte fayda vardır. (McDonald, 1997 s. 266) 
Doğrudan tepki reklamları, geleneksel reklamlara benzemesine rağmen, hedef pazardaki üyelerine ürünün öncelikli ve ikincil yararları ile ilgili bilgi sağlamaktadır. Ürünün nasıl teslim edildiği, nasıl çalıştığı, nasıl yapıldığı veya dizayn edildiğine bağlı olarak tüketicide güvenilirlik oluşturulur. Bu güvenilirlik olgusu reklamdaki kanıtlardan ve referanslardan elde edilmektedir.

Doğrudan tepki televizyon reklamlarının bir özelliği de, tekrar tekrar gösterilmesidir. Böylece hedef kitleye ulaşıp, onları sipariş vermeye yöneltmek için 60 dakika baskı altında tutar.

Pazarlık şansı sunması, garanti memnuniyeti ve kolay sipariş imkânı sunması gibi özellikleri ile risk azaltılır ve kolayca alışveriş etme deneyimi, ikna, güven ve hesaplı alışveriş imkânı sunar.

\section{Geleneksel televizyon reklamları ile doğrudan tepki televizyon reklamlarının}

karssılastırılarak incelenmesi: Geleneksel televizyon reklamları ile doğrudan tepki televizyon reklamları arasında farklılıklar bulunmaktadır. Bu aşamada bu farklılıkları incelemek yerinde olacaktır.

Doğrudan tepki televizyon reklamlarının reklamcılık methodlarında ki önemi yükselmeye başlamıştır. Örneğin Amerika'da ve İngiltere'de yayındaki televizyon reklamlarının yüzde yirmisinden fazlası doğrudan tepki mesajını yansıtmaktadır (DANAHER, et al., 1997 s. 46-58). Bu yükseliş doğrudan pazarlama firmalarının ve geleneksel pazarlama firmalarının ikisinin birden eseridir (MC KENNA, 1995 s. 87-95). Firmalar son y1llarda tutundurma faaliyetlerinde büyüyen trend olarak doğrudan tepki televizyon reklamları ile geleneksel televizyon reklamlarını bir arada kullanmak istemektedirler (BUSH, et al., 1990 s. 7-8). Bunun en büyük nedenlerinden biri ise geleneksel firmalarda da artık, müşterilerini “daha iyi tanıma” arzusunun bulunmasıdır. Böylece geleneksel firmalar, kitle iletişim araçları ile hedef kitleye ulaşmanın zorluğunu ve müşteri isteklerinin heterojenliğinin artmasını, doğrudan tepki yöntemi ile yanitlamaktadırlar (MC KENNA, 1995 s. 87-95).

Geleneksel televizyon reklamları, diğer medyada bulunan reklamların sadece video hali değildir. Televizyon reklamları, farklı ürün ve hizmet yelpazesini de temsil eder. Reklam iletişimindeki bu kültürel etki, farklı bir vurguya, farklı bir yapıya sahiptir ve bizim yaşamımızdaki nesne ve işlemleri tanıtmaktadır (BOGART, 1988 s. 76). 
Ürünlerde küçük farklılıklar olabilmektedir. Örneğin parfümlerdeki gibi. Fakat bu farklılıkların müşterinin zihninde yer edinmesini reklamcılar sağlar. Yani, reklam imajının etkinliği, fahiş üretim ve dağıtım maliyetlerinin tehdidi altında olmasına rağmen, müşterinin zihninde bir imaj yaratılmaktadır. Bu imaj bir stratejinin ürünüdür. $\mathrm{Bu}$ imajı reklamcılar, görsellik ve doğrudan tepki televizyon reklamlarını birleştirerek verirler. Aslında şunu söylerler; "Paranızın karşılığını daha fazlasıyla alın” (SEITZ, 1998 s. 268).

Kobs 1979 yılında yaptı̆̆ı çalışmasında doğrudan tepki televizyon reklamlarının diğer reklamlar ile arasındaki farkı anlatan karakteristik özellikleri şu şekilde sıralamıştır: (JAMES, et al., 1990 s. 24)

Doğrudan tepki televizyon reklamları, reklam ve satışı birleştirir.

Doğrudan tepki televizyon reklamları, anında geri dönüşüm mekanizmasına sahiptir.

Doğrudan tepki televizyon reklamları, hizmetleriyle ürüne değer katar.

Doğrudan tepki televizyon reklamları, hareket odaklıdır.

Doğrudan tepki televizyon reklamları, doygunluğun olduğu kanallardaki pazarlamacılar için ayrı ve önemli bir kâr merkezi kurabilir.

Doğrudan tepki televizyon reklamları, ürün dağıtımında kontrol avantajı sağlar.

Doğrudan tepki televizyon reklamları, pazar penetrasyonunu maksimize eder.

Doğrudan tepki televizyon reklamları, pazarlamada toptan hesap verebilmeye izin verir.

İcerik açsından doğrudan tepki televizyon reklamlarının incelenmesi: Bilgi vermek açısından doğrudan tepki televizyon reklamlarına bakıldığında, doğal yapısının, reklam stratejisinde bulgular sunmak olduğu görülmektedir. Bu bulgular, bilgi gerektirmektedir. (JAMES, et al., 1990 s. 24) Yani doğrudan tepki reklamlarında bilgi unsuru daha fazla görülmektedir. Çünkü aslında bu tarz reklamlarda bilgi zaten beklenmektedir.

Bilgi içeriği açısından doğrudan tepki televizyon pazarlaması, 1988 yılında Lebourveau, Dwyer ve Kernan 1989 yılında James ve Bergh, 1990 yılında James ve Bergh tarafından incelenmiştir. (LEBOURVEAU, et al., 1988 s. 25-34) (JAMES, et al., 1989 s. 7-14) (JAMES, et al., 1990 s. 23-29) 
Lebourveau, Dwyer ve Kernan çalışmalarında "harekete geçirici bilgi" den söz etmektedirler. Harekete geçirici bilgiden; yerelleştirilebilir, tanımlayıcı ve taktiksel olarak söz eden araştırmacılar, yerelleştirilmiş bilgiyi; "Noel'i size getiriyoruz" gibi söylemlerle, zaman ve mekan unsurunun tüketici için sağlandığı bilgi çeşidi olarak tanımlamaktadır. Tanımlayıcı bilgiyi ise; ürün ve hizmetin özellikleri hakkında verilen bilgi olarak, taktiksel bilgi olarak ise; “0800’lü numarayı bugün arayın, sınırlı sayıda ürün sizin için özel fiyatlarla" şeklinde tanımlamaktadırlar. (LEBOURVEAU, et al., 1988 s. 27)

Doğrudan tepki içeren veya doğrudan tepkiyi destekleyen, doğrudan televizyon pazarlaması; infomercial (tanıtıcı reklamlar) ve home-shopping (evden alışveriş) kanalları oluşturmaktadır. (KOTLER, et al., 2005 s. 512; McDonald, 1997 s. 264)

\subsubsection{Home shopping kanalları}

Home shopping yani Türkiye'de bilinen adıyla “evden alışveriş kanalları” doğrudan tepki televizyon pazarlamasının bir türü olarak karşımıza çıkmaktadır. Evden alışveriş kanalları, televizyon programı şeklinde olabildiği gibi, tüm kanalda yayın yaparak ürün ve hizmet satmaktadır. QVC (Quality Value Channel), HSN (Home Shopping Network) ve Value Vision gibi kanallar ürün ve hizmet satışı için 24 saat yayın yapmaktadır. (KOTLER, et al., 2005 s. 513) Örneğin Türkiye'de Shopping Tv 24 saat bu şekilde yayın yaparken, "Her eve lazım" programı Kanal D ve Star gibi normal yayın yapan kanallarda gösterilmekteydi. Daha sonra uyduda D shopping kanalında "Her eve lazım" olarak 24 saat yayın yapmaya başlamıştır. Bu kanallarda ürün kategorileri ve sunucular değişerek bilinen markalı ve hiç bilinmeyen markalı ürünlerin satışını ve tanıtımını gerçekleştirmektedir. (HER EVE LAZIM, 2011; SHOPPING TV)

Homeshopping kanalları, izleyicinin dikkatini çekmek için eğlence ve satış kombinasyonunu kullanan, geleneksel televizyondaki yaratıcı programların sonucudur. Homeshopping kanallarında sipariş telefon ve kredi kartı kullanılarak yapılmaktadır. (McDonald, 1997 s. 276)

\subsubsection{Infomercial Reklam}

Infomercial reklam kelime anlamıyla, İngilizcedeki information ve commercial kelimelerinin birleşmesinden türemektedir. Kelime anlamından da anlaşılacağı üzere, bir amacı ürün ya da hizmet ile ilgili bilgi vermek iken, diğer amacı ürün ya da hizmeti 
satmaktır. Bu nedenle, ücretsiz bir telefon numarası ve internet adresi reklamda bulunur. (Vikepedia Sözlük, 2011)

ABD'de özellikle kablolu tv yayınlarının ucuz olduğu saatlerde yani gece yarısından sonra 02.00 ve 6.00 saatleri arasında karşımıza çıkan, (Vikepedia Sözlük, 2011) geleneksel kuşak reklamlarından uzun süren, ürünün özelliklerini ve kullanım şekillerini bir sunucu, uzman, halktan bir tüketici, sunucu veya ünlü kişi tarafindan anlatılan, sipariş verilmek üzere telefon numarası veya internet adresinin verildiği reklam türüdür.

Infomercial reklam hemen hemen bütün pazarlama iletişimi süreçlerini ele almaktadır. $\mathrm{Bu}$ reklam için bir pazarlama iletişim türüdür diyebiliriz. Tüketici karar verme sürecini, hiyerarşiye tepkiyi, kaynak faktörleri, mesaj çekiciliğini, uygulama tekniklerini, hatta yasal ve etik konuları içerdiğinden tüketici davranışı kursu gibidir. (BELCH, et al., 2006 s. 23)

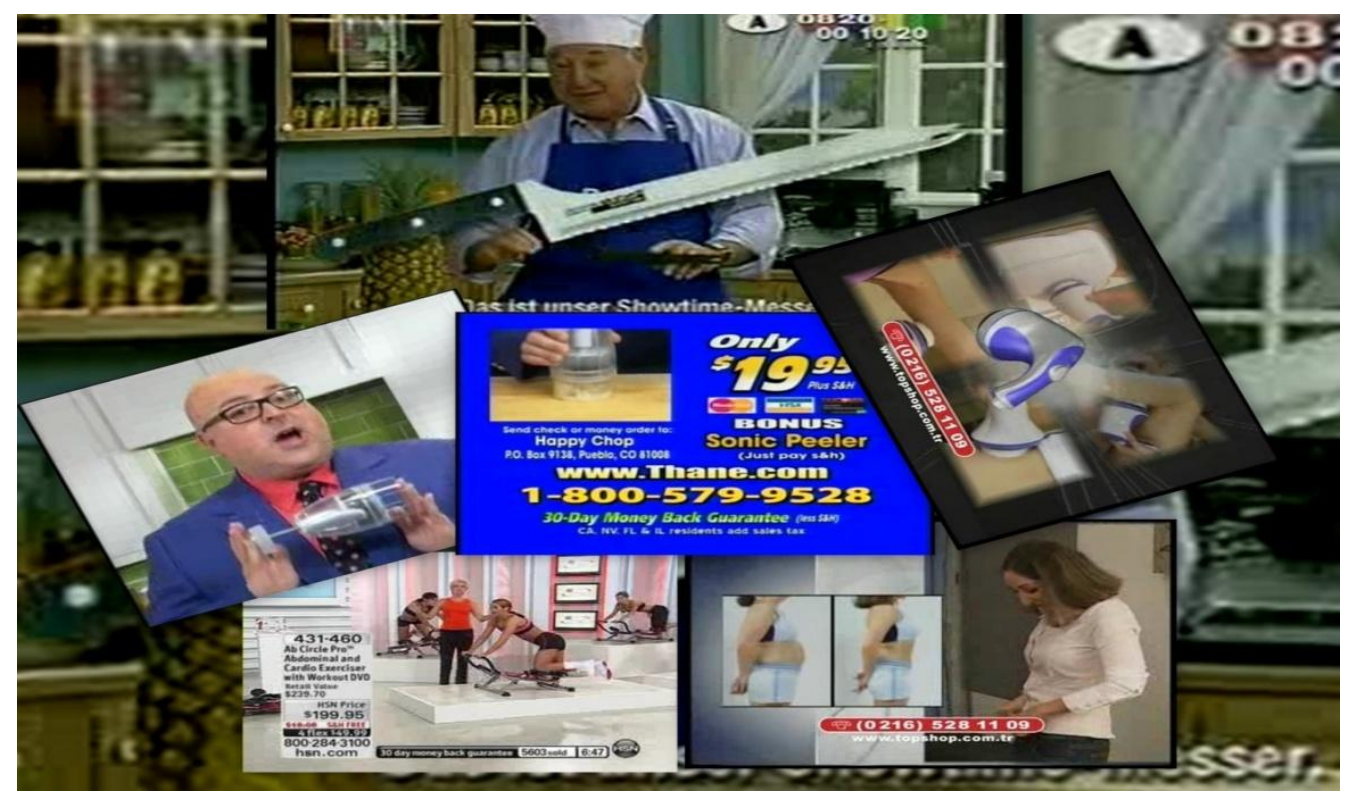

Infomercial reklamın tanımını Balasubramanian, "bilgi ve ikna yoluyla örgütün ürün ve imajının tanıtımını yapan, program formatı uzunluğundaki ücretli reklam türüdür.” şeklinde açıklamıştır. (BALASUBRAMANIAN, 1994 s. 29-46)

Gün geçtikçe ürün hakkında bilginin kaynağı olarak popülaritesi artan infomercial ya da diğer adıyla tanıtıcı reklam, program içeriğine benzeyen formatıyla televizyonda yayınlanan reklam türüdür. (DONTHU, et al., 1996 s. 69) 
Infomercial reklamların temel özellikleri geleneksel reklamlardan uzun süreli reklam olmalarıdır. Bu bağlamda çeşitli kaynaklara göre süreleri değişebilmektedir. Örneğin Donthu ve Gilliland infomercial reklamı tanımlarken "30 dakikadan 2 saate kadar olan ve ucuz medya saatlerinde yayınlanan uzun süreli tanıtıcı-bilgilendirici reklamlardır." (DONTHU, et al., 1996 s. 69) şeklinde reklam süresini bu kadar uzun belirtirken, Belch'ler “3 ile 60 dakika arasında değişen, tüketicilere ürünler ile ilgili bilgi verirken, yararları ve onları nasıl kullanacaklarının anlatıldığı, ayrıntılı bilgi veren televizyon reklamlarıdır." (AGEE, et al., 2001 s. 35) şeklinde açıklamaktadır. Günümüzde 5 dakikalık şeklinin de popülerlik kazandığı görülmektedir.

Ayrıca infomercial reklamlar doğrudan tepki televizyon endüstrisinin de önemli bir parçası haline gelmiştir. Bu endüstri de homeshopping kanalları ve 2 dakikanın altındaki kısa formatlı televizyon formatlarını da kapsamaktadır. (BELCH, et al., 2006 s. 24)

Infomercial reklamların otuz dakikalık bilgi sürecinde izleyici, ona sunulan markayı değerlendirebilir, ürünü satın alabilir ve katalog siparişinde bulunabilir. (ELLIOTT, et al., 1996 s. 45)

Infomercial reklamın tarihsel sürecine baktığımızda, yaklaşık 1970’lerden itibaren çocuklara hitap etmek amacıyla, parodi kısmı olarak kullanılmaktaydı. (BELCH, et al., 2006 s. 24) 1948 yılında Türk şekerlemeleri Bonomo'nun televizyon reklamı ve satışı yapılmaya başlandı. "Sihirbaz palyaço" ile çocuklara hitap eden program televizyonun ilk saatlerinde yani sabah 8.00'den 11.30'a kadar NBC'de Pazar günleri yayınlanmaktaydı. Program 1970'lere kadar devam etti. (ALL BUSINESS) Modern infomercial reklamların gelişimi 1980'li yıllarda Federal İletişim Komisyonunun reklamlardaki sınırlamaları kaldırmasıyla başlamıştır. Televizyon reklamları o dönemlerde iki dakikanın da altında bir uzunlukta, sınırlı olarak satılmaktaydı (BELCH, et al., 2006 s. 24).

Infomercial reklamın sağladığı kolaylıklar yanında, karşı karşıya olduğu problemlerde vardır. Bir müşteri mağazadan bir ürün satın alırken ürünü gözü ile görebilmekte ve ona dokunabilmektedir. Fakat televizyondan (hem infomercial reklamlardan hem de home-shopping kanallarından) alışveriş eden müşterilerde buna bağlı sorunlar ortaya çıkmaktadır. Çünkü televizyondan alışveriş eden bir kişi ürünü 
kendisi göremez ya da kendisi dokunamaz, onu deneyemez (HETSRONI, et al., $2002 \mathrm{~s}$. 36) (SALOMON, et al., 1992)

Infomercial reklamların en önemli özelliği, bilinmeyen veya şüpheli kabul edilen ürünler üzerine reklam yapılmasıdır. Örneğin yiyecek kurutucusu, zihin okuma programları gibi. Bu nedenle bu reklam türü toplum tarafından fazla farkedilmeyen bir reklam türü olarak karşımıza çıkmaktadır. Yapılan çalışmalarda infomercial reklamlarda müşteriye, herhangi bir satış elemanın veremeyeceğinden daha fazla bir bilgi yüklemesi yapıldığı görülmektedir. Hedef kitlesini geleneksel reklamı sevmeyen kitle oluşturmakta, böylece bu kitle infomercial reklamlardan satın almaya ikna edilmektedirler. Stark'a göre, genellikle infomercial reklamdan ürün ya da hizmet satılan kişiler, satın alma niyetinde olmayan, fakat reklamın dikkat çekiciliği ile satın alması sağlanan; genel geçer bir kitledir. (HETSRONI, et al., 2002 s. 34-37)

Infomercial reklamlar ayrıca, ürün hakkında detaylı olarak kanıtlar sunar. Sunulan kanıtlar ile kişi empati kurar ve kendisi ürünü kendisi kullanıyormuş gibi hisseder. Böylece vekaleten öğrenme deneyimi yaşamaktadır. (BALASUBRAMANIAN, et al., 2000 s. 61)

Genel olarak infomercial reklam izleyicinin satın alma kararı boyunca, para iade garantisi veren, deneme teklifi sunan, ihtiyaçlarını deneme, tanıma ve satın alma imkânı veren reklam türüdür. Infomercial reklamlar hem mantığa hem de duygulara hitap etmektedirler. Mantığa hitap ederken bilimsel kanıtlar gösterirler, duyguya hitap ederken ise sokaktaki bir kişi tarafından ürünün kullanılmasını ( ya da ürüne referans olma -testimonial) sağlarlar. Bunu yaparken sınırlı bir zaman verip, bazı promosyonlar (hediyeler) ve/veya fiyat indirimleri yaparlar. (BELCH, et al., 2006 s. 23)

Infomercial reklama yönelik yapılan ilk çalışmalarda, potansiyel (olası) müşterilerin karakteristik özellikleri üzerinde yoğunlaşılmış ve bu çalışmalar potansiyel müşterilerin sosyo-demografik yapısı ile ilgili sonuçlar vermiştir. Örneğin 1987 yılında James ve Cunnigham'ın ve yine 1987 yılında Darian'ın yaptıkları çalışmaların sonucunda, doğrudan tepki televizyon reklamlarından alışveriş yapan kitlenin orta yaş üstü kadınların olduğu kabul edilirken, 1996'da Donthu ve Gilliland'ın çalışmasında ise, hiçbir karakteristik özelliğin ya da yaş, gelir, eğitim veya cinsiyetin etkisinin bulunmadığı görülmektedir. Araştırmacılar infomercial reklam müşterilerinin, geleneksel yöntemlerle alışveriş yapan müşterilere göre rahatlığına, çeşitliliğe ve 
maliyet etkinliğine daha çok önem verdiklerini kabul etmektedirler. (JAMES, et al., 1987 s. 12-23; DONTHU, et al., 1996 s. 69-76)

Ayrıca yine Donthu ve Gilliland'ın araştırmalarına göre, infomercial reklam müşterilerinin, müşteri olmayanlar ile kıyaslandığında, geleneksel reklama ve doğrudan pazarlamaya tutumlarının pozitif olduğu belirtilirken, geleneksel alışverişe yönelik tutumlarının negatif olduğu görülmektedir. (DONTHU, et al., 1996 s. 69-76)

Potansiyel müşterilerine ulaşabilmek için bazı temel markalar da infomercial reklamları kullanmaktadırlar. Saturn, Volvo, Lexus, Apple, Phillips, Braun, Nissan, Time Life gibi çeşitli markalar potansiyel müşterileriyle iletişim kurabilmek için infomercial reklamlardan yararlanmışlardır. (BALASUBRAMANIAN, et al., 2000 s. 59) (BELCH, et al., 2006 s. 24) Infomercial reklamlarda yaratılan marka farkındalığının sonucunda, perakende satışlardan arta kalan \%25'lik oranda bir satışın infomercial reklamlardan, doğrudan yapıldığı belirlenmiştir. (WICKS, et al., 2001 s. 41-53)

Geleneksel reklamlar ile infomercial reklamlar arasındaki farklılıklara değinmek gerekirse, en temel farklılık mesajın ve formatın uzunluğudur. Geleneksel televizyon reklamında bir dakika veya daha az bir süre içerisinde hedef kitleye ikna edici mesaj içeriği vermek gerekmektedir. Buna karşıllk infomercial reklamlar 30 dakika veya daha fazla sürer ve reklamdan daha çok bir programa benzer. (BALASUBRAMANIAN, et al., 2000 s. 62)

Infomercial reklamın özellikleri: Infomercial reklamlar ile ilgili özellikleri genel olarak toparlayacak olursak;

Uzun süreli bir reklamdır.

Program içeriği gibi olan reklamlardır.

Detaylı bilgi verir (bilgiyi detaylandırarak verir)

Özellikle pek çoğunda telefon ve internet adresi bulunmaktadır.

Özellikle yeni çıkarılan bir ürün ile ilgili tüketiciyi ikna etmenin en kolay yoludur.

Bir anlatıc1-sunucu vardir.

Kanıt gösterilir.

Güvendiğiniz biri sizin için ürünü test eder.

Satış amaçlıdır. (Doğrudan satış yapmayı hedefler) 
Ürün ya da marka ile ilgili farkındalığı sağlar ve bu farkındalığ bilinirliğe dönüştürür. Yani marka ile ilgili farkındalığı derinleştirir. Örneğin Braun, Philips vb. markalarda bu tarz reklamları kullanabildiği gibi piyasaya yeni giren markalar da bu tarz reklamları kullanmaktadırlar.

Reklam veren açısından kuşak reklamlarından ucuzdur. $\mathrm{Bu}$ yüzden kriz dönemlerinde en çok tercih edilen reklam türüdür.

Reklam kargaşası içerisinde hatırlanabilme olasılığı yüksektir.

Geri dönüşüm açısından bakıldığında hızlı bir geri dönüşüm sağlar.

Tüketici açısından bakıldığında evde sadece bir telefon yardımıyla satın almayı gerçekleştirebildiğinden zamandan tasarruf sağlar. Aynı zamanda aldığı ürünlerin yanında hediyelere de sahip olma avantajı sunar. Piyasa fiyatından uygun olduğunun söylenmesi de tüketiciye cazip gelmektedir.

İcerik açsından Infomercial Reklam: 1990 yılında kurulan ulusal infomercial reklam pazarlama birliği NIMA, tarafından geliştirilen, Infomercial reklamların program içerikleri şu şekildedir (ELLIOTT, et al., 1996 s. 49).

Tanıtım gösterisi: Başlıca amacı, kullanılan ürünü göstermektir. Program süresince, sunucu, ürünün nasıl kullanıldığını, ürünün rakiplerine göre performansını ve bakımının nasıl yapıldığını açıklamaktadır.

Testimonial (Görüşlerin bildirildiği reklam): $\mathrm{Bu}$ programlar uzmanların saygınlığından ve ünlü/ünsüz kişilerin desteklemelerinden yararlanır. Kısaca kişiler bu ürünleri test ettiklerini ve memnun kaldıklarını anlatırlar. Reklamdan önce ve sonra uzman kişilerin görüşleri alınır. İnanırlığı sağlamak için özellikle halktan kullanıcılarla, spontane olarak cadde ve sokak gibi yerlerde sokak röportajı şeklinde yapılarak görüşler, alınir.

Documercial (Haber programı gibi reklam): Bu programlar genellikle haber görünümlü, araştırma raporları sunan, aslında kurgusal olmayan çarpıcı programlardır. $\mathrm{Bu}$ tarz reklamlar sık sık formatlarıyla izleyici üzerinde algısal bir karşıtlık yaratarak, izleyicinin dikkatini çeker ve saygınlığ 1 arttırır.

Talk show: Talk showlar eğlencenin değerine ve anketörün karizmasına bağlıdır (anketör genellikle iyi bilinen veya ünlü olan bir sunucudur). Bu programlar hedef kitlede heyecan yaratmaya bel bağlar ve "documercial" lara benzerler. Ayrica, 
bildik bir televizyon programı şeklinde yapıldığından, onun reklam niyetini saklamaktadir.

Dramatize etme: $\mathrm{Bu}$ tarz reklamlar "storymercial" ismiyle anılmaktadir. Storymercial aslında bilinen ürünün hikayesinin etrafinda dönen 3 perdelik bir oyundur (FAIRCHILD, 1998). Yani, sitcom şeklinde, yaşamdan bir kesit sunan programlardır. Burada ürün tüketicinin problemini çözmektedir. Documercial gibi, hikayeden yola çıkarak, algıda yaratılan karşıtlıkla izleyicinin ilgisini çeker.

Infomercial reklamlar genellikle yaşamdan bir kesit sunarlar. Örneğin sinirli bir kadın reklamda karşımıza çıkar. Infomercial reklamın amacı bu kadının sinirini bozan durumu önce tanımlamak sonra da ortadan kaldırmaktır. Bu örnekteki kadın bir ev hanımıdır ve onun saklama kapları hava geçirdiğinden yiyecekleri küflenmiştir. Kadın bu yüzden sinirlidir. Fakat reklamın devamında devrim yaratıcı bir teknoloji karşımıza çıkacaktır. "Gıda Hava Geçirmezlik sistemi” Sonra stüdyoya bir ünlü ya da sunucu girecek ve bu yeni ürünü izleyiciye göstererek konuşmaya başlayacaktır. Bu ünlü kişi izleyiciye bilgi vermektedir. Ve genellikle yanlarında bir tane de uzman kişi bulunur, bu kişi de ürünü dener. Örneğin bu kişi bir şef olabilir ve yemek yapar. Diğer taraftan da bilimsel olarak yiyeceklerin nasıl hava geçirmeyeceği, animasyon yardımıyla anlatılır. Daha sonraki aşama duygusal boyuta hitap şeklindedir. Kızgın kadın bir annedir ve onun bu ürünle birlikte hem paradan hem de zamandan nasıl tasarruf ettiği anlatılır. Ayrıca anne artık ailesiyle birlikte daha fazla zaman geçirebilecektir. Bu sayede insanlar ürünü sevmeye başlarlar. Bu aşama infomercial reklam için kişinin ürünü satın almaya en yakın olduğu zamandır. Ayrı bir ekranda, alt reklam ya da bant reklam şeklinde, fiyat ve ödeme seçenekleri görülür. Fiyat izleyiciye daha önceden söylenmemesine rağmen, "bu ürün $200 \$$ değil, 150 \$ değil, sadece 120\$” şeklinde bilgi verilir. Ve bu şekilde 19.99\$ kâr elde edileceği izleyiciye söylenir. Ayrıca bu ürünün belirli bir zaman dilimi içerisinde alındığında yanında hediyeler verileceği söylenir. Ürünün ödemesi yapıldıktan sonra bu ürünü deneyebilecekleri, beğenmedikleri takdirde de para iadesi yapılacağı söylenir. Bu süre zarfında ürünün satışını sağlamak amacıyla her türlü bilgi, internet adresi, telefon numarası, kredi kartıyla ödeme bilgileri ekranda izleyiciyle paylaş1lır. (BELCH, et al., 2006 s. 23)

\section{Infomercial reklamlarda bilgilendiricilik unsuru:}


Resnik ve Stern 1977 yılında geleneksel televizyon reklamlarının bilgi içeriğini analiz etmişlerdir. Geleneksel reklamların bilgilendirici olarak kabul edildiği varsayımından yola çıkan Resnik ve Stern, tipik bir izleyicinin reklamı izledikten sonra satın alma kararı verdiğinden bahsetmektedirler. Diğer bir deyişle reklamlarda bilgilendiricilik unsuru sağlandığında, izleyicilerin satın alma kararı vermesinin kolaylaştığı ön görülmüştür. Bu bağlamda on dört maddeye sahip bilgi ölçeğini geliştirmişlerdir. Bu bilgi ölçeğini "fiyat değeri”, "kalite”, “performans”, "bileşenler veya içerik", “elde edilebilirlik", “özel sunumlar”, “lezzet”, “besleyicilik”, “ambalajlama ya da şekil”, "garanti ve teminat”, "güvenlik”, "bağımsız araştırmalar”, “firma araştırmaları”, “yeni fikirler”, boyutları oluşturmaktadır. (RESNIK, et al., 1977)

Elliot ve Lockard 1996 y1lında infomercial reklamlara yönelik bilgi içeriği analizi yaptıkları çalışmalarında Resnik ve Stern'in 14 maddelik ölçeğinden yararlanmışlardır. Bu çalışmadaki bulgular, önceden yapılan; doğrudan tepki televizyon reklamları, geleneksel televizyon reklamları ve dergi reklamları araştırmalarıyla karşılaştırıldığında, infomercial reklamlarda ortalama 5,82 oranında daha fazla bilgi unsurunun bulunduğunu göstermektedir. (ELLIOTT, et al., 1996 s. 44-56)

Infomercial reklamlarda ürünü tanttan kiși kategorileri: Infomercial reklamlarda destekleyici olarak yer verilen kişiler şu şekilde tanımlanabilir; (WICKS, et al., 2005 s. 97)

Ünlüler: Reklamlarda boy gösteren ün ya da başarı kazanmış kişi olarak tanımlanır. Bu kişiler, televizyonlarda ya da filmlerdeki aktör-artist, profesyonel basketbol ya da futbol oyuncusu, bir olimpiyatçı ya da akademik sporcu veya futbol basketbol starı gibi başarıya ya da üne ulaşmış kişilerdir. Bu kategori ayrıca, bilindik ya da tanıdık olmamasına rağmen infomercial reklamlarda bir ünlü gibi tanıtılan kişileri de kapsamaktadir.

Medikal doktor, psikolog, dişçi veya diğer doktorlar: Reklamlarda boy gösteren, medikal doktor, dişçi veya diğer doktorlardır. Buradaki unvanlar ya sözle söylenir ya da yazıyla mutlaka gösterilir. (Dr. Levine gibi)

Diğer uzmanlar: Reklamlarda boy gösteren, doktor ya da psikologlardan başka, antrenmanlarla, eğitimlerle, başarılarla kazanılmış uzmanlığa ya da unvana sahip kişilerdir. Örneğin bir fitness uzmanı; diyet veya egzersiz ürünlerle ilgili bilgi 
vermektedir. Bu kategori uzman olarak tanımlanan ve/veya seçtiği alandaki başarıları ve kazandığı deneyimler doğrultusundaki uzmanlığı olan veya çeşitli türlerde sertifikalara, eğitimlere sahip olarak bilinen kişileri içermektedir.

Firma, ürün veya hizmet tanıtım elemanlart: Bir firma sahibi, yöneticisi veya firmanın tanıcısı olarak çalışanı, üreticiler, infomercial reklamdaki ürünleri veya hizmetleri satan kişiler olarak görünürler. $\mathrm{Bu}$ kişi, ürün veya hizmetin satışında, yapımında veya reklam sponsorluğu görevinde firma ile birlikte çalışan kişi olarak tanımlanır.

Infomercial reklam ile geleneksel reklamın karșılaștırılması: Infomercial reklam ile geleneksel reklamların formatlarının karşılaştırılması şu şekildedir. (BALASUBRAMANIAN, et al., 2000 s. 62)

Reklama maruz kalma açısından süreçlere bakıldı̆̆ında, televizyonda çok fazla sayıda geleneksel reklam bulunmaktadır ve bu reklamlar tüketicinin zihninde karışıklığa yol açmakla birlikte dikkat dağınıklığına da neden olmaktadır. Tüm bu karmaşa içerisinde ise reklama maruz kalma sınırlı bir şekilde olmaktadır. Çünkü geleneksel reklama maruz kalma çok tesadüfi bir olaydır, insanlar kendi seçimiyle reklama maruz kalması ise çok düşük bir ihtimaldir.

Infomercial reklama maruz kalmada süreç, daha uzundur ve insanlar bunu kendileri seçerler. Çünkü burada reklamın tasarımı hedef kitlenin ilgisini çekmek ve ilgiyi korumak şeklinde tasarlanmıştır.

Kişinin hafizasına etki açısından bakıldı̆̆ında, geleneksel reklamda hafızaya etki, maruz kalma ile doğru orantıdadır ve bu nedenle de sınırlıdır.

Infomercial reklamlarda, reklama maruz kalma uzun süreli olduğu için, burada anahtar noktalar ile gösteri pekiştirilmekte böylece hafızaya etki seviyesi de orta seviyelerde olmaktadır.

Tüketicinin tutumuna etkisi açsından bakıldığında, geleneksel reklamlarda yine kısa sürede maruz kalmaya bağlı olarak sınırlıdır.

Infomercial reklamlarda ürün vekaleten denendiği için tüketicinin tutumu olumlu yönde etkilenebilmektedir. Bu nedenle burada etki ortalama seviyededir. 
Tüketicinin satın alma niyetine etki açısından bakıldığında, geleneksel reklam, yine kısa sürede maruz kalmaya bağlı olarak sınırlıdır.

Infomercial reklamlarda maruz birakma ve tekrar etme uzunluğuna bağlı olarak doğrudan tepki araçlarının kolaylıkla kullanılması satın alma niyetini ortalama seviyede tutar.

Baskın tüketicilerin öğrenme biçimi açısından bakıldı̆̆ında, geleneksel reklamlarda dahil olarak öğrenme düşük, infomercial reklamlarda vekaleten öğrenme söz konusudur.

\subsection{Türkiye'de Doğrudan Pazarlama Uygulamaları}

Türkiye'de doğrudan pazarlama uygulamaları, 1990'lı yıllarda büyüme göstermektedir. $\mathrm{Bu}$ büyümenin nedenini Karafakıoğlu, internetin ve kredi kartının ülkemizde kullanımının yaygınlaşması olarak göstermektedir. (KARAFAKİOĞLU, 2006 s. 211) Aynı zamanda özellikle bu dönemde doğrudan pazarlama şirketleri Türkiye pazarına girmeye başlamışlardır. Örneğin katalog pazarlaması örneklerinden ilk olarak Oriflame, 1993 yılında Avon ve 1994 yılında ise Amway Türk pazarına girmişlerdir. Bunlara ek olarak Tupperware'nin sektöre girişiyle, sektörün sesini duyurmak üzere, 1992-1997 yılları arasında, "Doğrudan Satış Derneği”ni kurmuşlardır. (ÖZMORALI, 2010)

Doğrudan tepki televizyon pazarlaması açısından Türkiye değerlendirilmeye alındığında, öncelikle Radyo ve Televizyon Üst Kurulu'nun televizyon izlenme oranlarını yayınladığı haftalık araştırmalara bakmak gerekmektedir. 


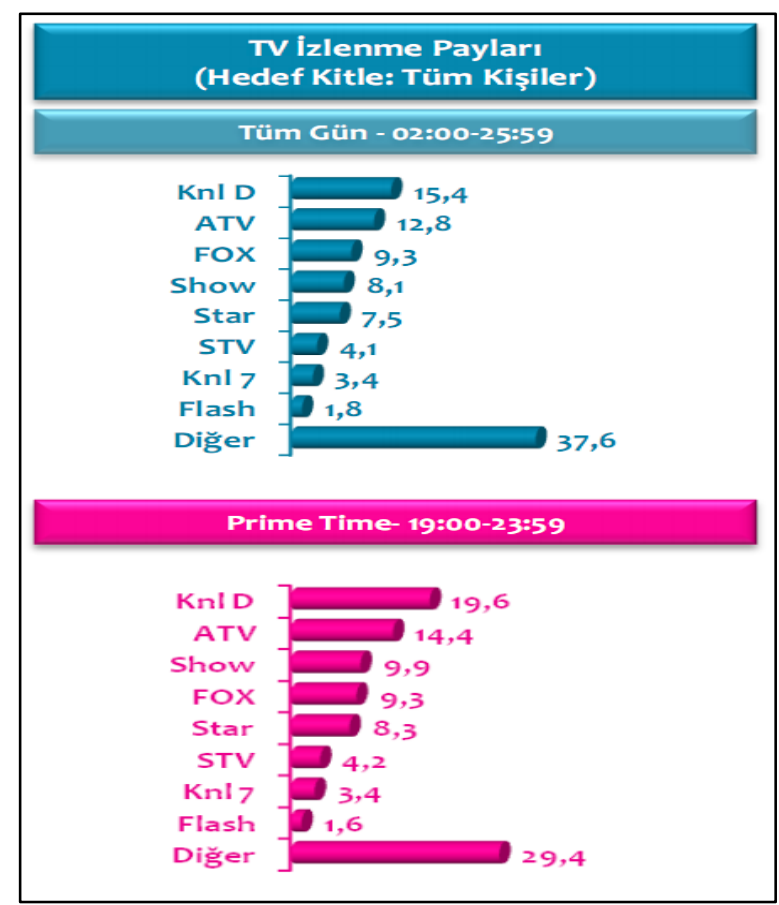

Şekil 4: Haftalık Tv İzlenme Payları

Kaynak: (CEREYAN MEDYA, 2011)

Türkiye'de son y1llarda artan teknolojik ilerlemelerle paralel olarak, televizyon ve radyo kanallarının çeşitlenmesi doğrudan pazarlama için önemli bir gelişme olarak değerlendirilebilir. Çünkü, program ve kanallar çeşitlenmiş, böylece de televizyon izleyicisi demografik özelliklerine göre dilimlendirilmiştir. (ÖZMORALI, 2010)

Türkiye'de homeshopping alanında Shopping tv, infomercial reklamlarda da Topshop bilinen doğrudan tepki reklamlarıdır.

ShoppingTV 2005 yılının Kasım ayında "Türkiye'nin Alışveriş Televizyonu” sloganıyla yayın hayatına başladı. Televizyondan canlı satış yapan ShoppingTV, aynı zamanda internet, çağrı merkezi, otomatik telefon yanıtlama sistem ve kısa mesaj servisleri ile satış gerçekleştirmektedir. ShoppingTV, ürünlerini ekranda açık artırma, açık eksiltme, dalgalı fiyat, doğrudan satış gibi farklı müzayede formatları ile sunmaktadır. Bu formatlar arasında en çok ilgi göreni "Açık Eksiltme" formatıdır ve bu formatta ürün yayına belli adetlerde çıkmakta, yayına çıkan adet tükenene kadar ürünün fiyatı düşmeye devam etmektedir. ShoppingTV'nin alışveriş sisteminde müşteriler TV'den izledikleri müzayedeyi aynı anda internetten de takip edebilmektedirler. Çağrı merkezini arayıp ürünü satın almak istediklerini belirtebilecekleri gibi, kısa mesaj servisine bir mesaj atarak da satınalmayı başlatabilmekte, eğer internetten izliyorlarsa, doğrudan web üzerinden alım gerçekleşebilmektedirler. Şu ana kadar satışı yapılan yaklaşık 11.000 adet ürün olmasına rağmen bu sayı her geçen gün artmaktadır. Her yıl 
ise yaklaşık 2 kat büyüme yaşandığı belirtilmektedir. 2007 yılında ayda ortalama 50,000 adet sipariş alınırken, bu rakam 2008 yılında 90,000 adede yükselmiştir. Bu bağlamda yapılan araştırmaya göre, müşteriler ilk alışverişlerinden sonra sisteme güven duymaya başlamakta, bu güven duygusu ile arkadaşlarına tavsiyede bulunmaktadırlar ve sisteme yeni üyeler katmaktadırlar. Yeni üye sayısındaki artış kanalın gelecekteki satış potansiyeli için en önemli gösterge niteliği taşıyor. $\mathrm{Bu}$ verilerin takibasyonunu sağlamak amacıyla ERP sistemi kullanılmaktadır. (MICROSOFT, 2010)

D shopping kanalında her eve lazım ile faaliyet gösteren program 2007 yılının başından beri Doğan Teleshopping A.Ş. tarafından sağlanan bir uzaktan satış hizmetidir. Önce uyduda yayına başlayan D shopping, HerEveLazim.com.tr ile faalitlerine devam etmiş, D smart 60. Kanaldan veya Turksat 3A uydusundan izlenebilmektedir. (HER EVE LAZIM, 2011)

Özellikle ABD'de ve Avrupa'da infomercial reklamlar, özellikle gece yarısından sonra 2.00 ila 6.00 saatleri arasında karşımıza çıkmaktadır. Infomercial reklamlarda tanıtılan ya da satılan ürün kategorileri, temizlik ürünleri, alet-edevatlar, yiyecekler, diet ürünleri, alternatif sağlık ürünleri, hafıza geliştirme kurları, kitaplar, müzik cdleri, videolar, gayrimenkul ile ilgili yatırım stratejileri, güzellik ürünleri, kellik ilaçları, zayıflatıcı ürünler, kişisel fitness aletleri ve ev için egzersiz aletleri şeklindedir. (Vikepedia Sözlük, 2011)

Ülkemizde ise infomercial reklamlar daha çok TOPSHOP markasıyla karşımıza çıkmaktadır. Özellikle normal televizyon kanallarında (uyduya ya da kablolu tv'ye ait olmayan kanallarda) karşımıza çıkan TOPSHOP reklamlarındaki ürünler, egzersiz aletleri, mutfak aksesuarları, diet programları, eğlence, sağlık, güzellik ve ev gereçleridir. (TOPSHOP, 2011)

TOPSHOP markası Orta ve Doğu Avrupa pazarında 21 ülkede faaliyet gösteren televizyondan doğrudan satış üzerine çalışan Studio Moderna'nın reklam markasıdır. Reklamda gösterilen ücretsiz telefon numarasının ardındaki çağnı merkezini de Studio Moderna kendi bünyesinde bulundurmaktadır. Doğrudan tepki televizyon reklamcılığı-infomercial- yanı sıra katalogla pazarlama, telefonla pazarlama, online pazarlama ve perakende mağazacılık sektöründe de faaliyet göstermektedir. 1992 yılından itibaren Türkiye'de hizmet vermektedir. (STUDIO MODERNA, 2011) 
TOPSHOP gibi kendi markalarını yaratan firmanın özellikle Kosmodisk ve Dormeo bilinen iki markasıdır. Bunların yanı sıra Delimano ve Wallmaxx markaları da mevcuttur. Kosmodisk; omurga güçlendirici, yoga seti, masaj yastığı vb. sağlık ürünlerini bünyesinde bulundurmaktadır. Kosmodisk Classic Omurga Masörünün reklamlarında bir uzman (doktor) ve ürünü kullanan tüketiciler yer almaktadır. Noter huzurunda çekilen bu reklamlardaki kişiler Studio Moderna'nın Türkiye'deki marka yöneticisi Can Erenberk'in vermiş olduğu bilgiye göre kendi memnuniyetlerini anlatmak üzere kamera karşısına geçmektedirler. Özellikle orta yaş üstü kullanıcılara hitap eden ürünün reklamında gördüğümüz tüketiciler yine orta yaş ve üzerindedirler. Ağızdan ağıza pazarlama yoluyla arkadaşlarına ve ailesine memnuniyetini anlatan tüketiciler daha fazla kitleye ulaşabilmek için kamera karşısına geçmişlerdir.

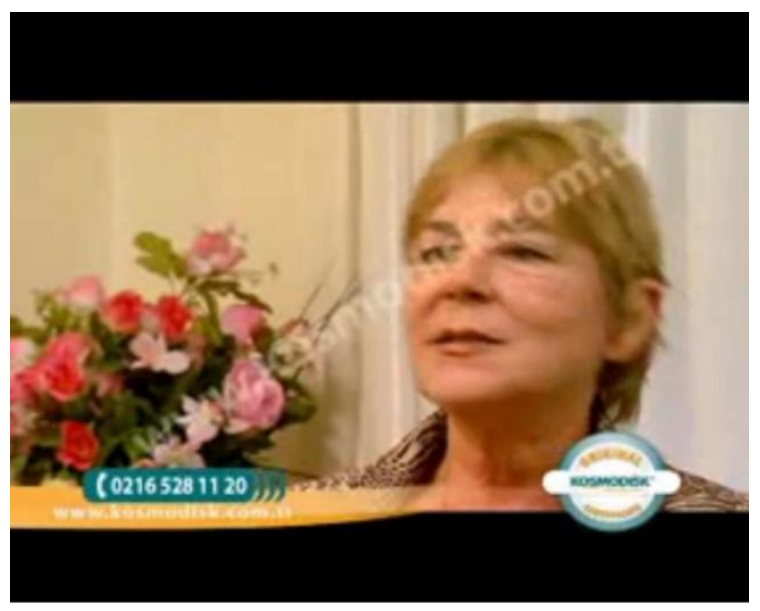

Infomercial reklamlarda ürünü alması için izleyiciye baskı yapılmaktadır.

Örneğin "bu ürünü şimdi alırsanız, yanında ek üründe veriyoruz/indirim yapıyoruz.” Ya da "Bu ürünü başka hiçbir yerde bulamazsınız. Orjinali sadece bizim ürünümüzdür." şeklinde ibareler kullanılmaktadır.

Infomercial reklam olarak ayrıca (DÜNYA PAZARLAMA, 2011) ve (TELE MARKET, 2011) internet sitelerinde yer alan ürünlerin reklamları da görülmektedir 


\section{BÖLÜM \\ TÜKETICI DAVRANIŞI VE TÜKETICII DAVRANIŞINI ETKILEYEN FAKTÖRLER}

\subsection{Tüketici Davranışı}

Bütün pazarlama faaliyetlerinin temel amacı müşteri yaratmak ve müşterinin kalıcılığını sağlamaktır (SHETH, 2002 s. 591). Artık daha seçici ve bilgili olan tüketiciler ve yoğun rekabet koşulları pazarlamacıları yeni teknolojiler, pazarlama yöntemleri kullanarak alternatif farklılaşma ve rekabet avantajı yakalama arayışlarına yöneltmektedir. (KURTULUŞ, et al., 2001 s. 52)

Tüketici davranışlarını; tüketicilerin algıları, öğrenme süreci, kişiliği ve tutumu gibi iç etmenlerle birlikte, kültürel geçmişi, içinde bulunduğu sosyal sınıf, etkileşimde bulunduğu insan ve gruplar gibi dış etmenler de etkilemektedir. (HOLLOWAY, et al., 1971 s. 9)

Tüketici davranışının temel özellikleri şunlardır (KARALAR, 2005 s. 7)

Tüketici davranışı kıt olan ürün ve hizmetlerle ilgilidir. Solunan hava tüketim davranışına konu olmazken, içtiğimiz arıtılmış su bu kapsamdadır.

Tüketici davranışı her türlü ürün ve hizmet ile ilgilidir. Tüketici davranışı somut, elle tutulur ürünlerin satın alınması biçiminde olabileceği gibi, soyut hizmetlerin satın alınmasını da içermektedir,

Tüketici davranışı her zaman rasyonel ve önceden tasarlanmış olmayabilir. Tüketiciler bir ürün ya da hizmeti önceden almayı planlayarak da atın alabilmekte, bazen de o anda, içinden geldiği gibi alışveriş edebilmektedir. Yani düşüncesizce/fevri hareket edebilmektedir.

Tüketici davranışı alışkanlıklara sıkı sıkıya bağlı kalabilmektedir. Örneğin, giysilerin sürekli olarak belli bir mağazadan satın alınması, hep aynı markaların tercih edilmesi alışkanlıklarla ilgilidir.

Tüketici davranışı bireylerin davranışlarının yanı sıra grupların davranışını da kapsamaktadır. İnsanlar belli davranışları toplu olarak gerçekleştirmekten 
hoşlanırlar. Arkadaşlarla sinemaya, alışverişe gitmek; aile ile yemek yemeye gitmek gibi.

Tüketici davranışı tüm örgütleri ilgilendirir. Kar amaçlı işletmeler, kar amacı gütmeyen örgütler ya da çeşitli toplumsal hizmetleri sağlayan kamu kuruluşları tüketici davranışları ile doğrudan ilgilidir.

\subsection{Tüketici Satın Alma Karar Süreci}

Tüketicilerin bir ürün veya hizmeti satın alırken sırayla takip ettikleri sürece tüketici karar verme süreci denir. (LAMB, et al., 1994 s. 103).

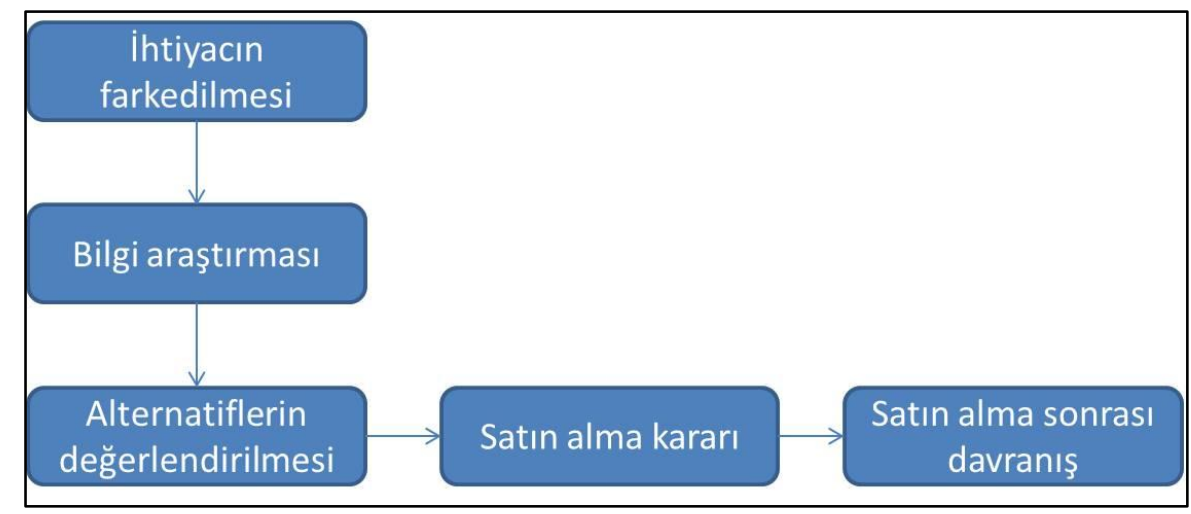

Şekil 5: Satın Alma Karar Sürecinin Aşamaları

Kaynak: KOTLER Philip Marketing Management, New Jersey : Prentice Hall, 2000. - Cilt 10., s.171

Satın alma karar sürecinin aşamaları; ihtiyacın farkedilmesi, bilgi araştırması, alternatiflerin değerlendirilmesi, satın alma kararı ve satın alma sonrası davranıştır.

Ihtiyacın Fark Edilmesi: Mevcut durum ile özlenen durum arasında fark oluşmasıdır. Satın alma süreci bu farkın hissedilmesiyle ortaya çıkar. Tüketicilerin ihtiyaçlarını fark etmesinde beş önemli nokta vardır: (LOUDON, et al., 1988 s. 593594)

Yetersiz ve tükenmiş ürünler

Kullanılan üründen memnun olmama

Çevresel koşulların değişmesi

Finansal şartların değişmesi

Pazarlama faaliyetleri 
Bilgi Arama: Bilgi arama konusunda tüketicinin başvurduğu kaynaklar dört grupta toplanır: (KOTLER, 2000 s. 179)

Kişisel Kaynaklar: Aile, arkadaşlar, komşular, akrabalar

Ticari Kaynaklar: Reklam, satışçılar, bayiler, paketleme

Kamu Kaynakları: Medya, tüketiciyi koruma dernekleri

Deneyimsel Kaynaklar: Ürünü kullanma, deneme.

Başarılı bir bilgi araştırması, tüketiciye olası birçok alternatifle karşı karşıya birakmaktadir.

Seçeneklerin Değerlendirilmesi: Tüketici bilgi arama aşamasında oluşturduğu seçeneklerini belirledikten sonra, önceliklerine göre, bunları değerlendirmek için çeşitli ölçütleri temel alacaktır. Eğer tüketici seçeneklerden tatmin olmazsa bilgi arama sürecine geri dönecektir. (KOTLER, 2000 s. 193)

Satın Alma Kararı: Satın alma karar aşamasında tüketici, seçenekler arasından tercihini belirlemektedir. Bu noktada tüketicinin satın alma niyeti ile satın alma kararı arasına bazı faktörler girmektedir. Bu faktörler onun satın alma fikrini değiştirmesine sebep olabilmektedir. Değerlendirmenin sonucu olumlu ise, malın cinsine, markasına, fiyatına, rengine, miktarına ve satın alınacağı yere ilişkin bir dizi karar verir. $\mathrm{Bu}$ aşamada, marka yöneticisi, reklam ve diğer yollar ile tüketiciye bilgi verir, karar almayı kolaylaştırır. Sonuçta, fiyat, teslim ve kredi sorunlarını çözümleyince satın alma kararını uygularak, satın alma işlemini gerçekleştirir. (KOTLER, 2000 s. 196)

Değerlendirmenin sonucu olumsuz ise, tüketici satın almaktan vazgeçer. Tüketici araştırma ve değerlendirme maliyetlerine rağmen, mevcut seçeneklerden hiçbirinin ihtiyacını karşılamayacağına inandığı için de satın almaktan vazgeçebilir. (BUSH, et al., 1985 s. 221)

Satın Alma Sonrası Davranış: Tüketicinin tatmini üründen elde ettiği performans ile sağlanmaktadır. Tüketiciler, ürünü satın aldıktan sonra da, bazı endişelere sahiptirler. Bu bağlamdaki endişe hali, doğru alım satım kararı verilip verilmediği kuşkusundan kaynaklanmaktadır ve bu zihinsel uyumsuzluk teorisi olarak adlandırılmaktadır. Eğer tüketici seçenekler arasından elediği ürünlerin bazı çekici 
özellikleri varken seçtiği üründe eksiklikler buluyorsa, tüketicide zihinsel uyumsuzluk hali ortaya çıkmaktadır. Tüketici o ürünü aldığına pişman olabilmektedir.

Tüketici tatmini ya da tatminsizliği en çok yakın çevresince hissedilecektir. Üründen memnun kalan tüketici arkadaşlarına, akrabalarına aynı ürünü almalarını tavsiye edecektir. İşletme, reklam, diğer tutundurma çalışmaları ve satış sonrası hizmetler ile satmış olduğu ürünler ile ilgili olarak tüketicide belirecek kaygıyı ve olumsuz duyguları silmeye veya en azından azaltmaya çalışır. (KOTLER, 2000 s. 198)

Satın Alma Karar Tipleri: Tüketici satın alma karar tipleri çok çeşitli olmakla beraber, bunlar üç grupta toplanabilir: otomatik satın alma davranışı, sınırlı karar alma ve yaygın sorun çözme. (SADIKOVA, 2006 s. 31-32; HATİBOĞLU, 1993 s. 38-39)

Otomatik satın alma davranışı: Bu durum, yeniden öğrenme ihtiyacının olmadığı veya çok az olduğu bir satın alma durumudur. Satın alan kişi yerleşmiş alışkanlıklara sahiptir ve düşünmeksizin bir markayı satın alır. Böylece güdülerini değerlendirmesi veya farklı markaları göz önünde tutması gerekmez. Bilgi ve değerlendirme kriterlerine ihtiyaç yoktur, çünkü geçmiş deneyimler sonucu bunlar yeterli düzeyde oluşmuştur. Uyarıcı onu doğrudan satın almaya yöneltir, ekmek kibrit, sigara vb. alımlarında olduğu gibi.

Sınırlı Karar Alma: Burada seçim kriterleri oluşmuştur ve tüketicinin daha az zamana gereksinimi vardır. $\mathrm{Bu}$ da alıcının biraz tecrübe sahibi olduğu mallara yönelik bir davranışı belirtir. Daha önce alınan markayı yeniden satın alma olasılığı yüksek de olsa, bazı yeni koşulların öğrenilmesi, diğer markaların üzerinde de durulması söz konusudur.

Yaygın Sorun Çözme: Bu durum ise, alıcının; hakkında çok az bilgiye sahip olduğu, önemli ve fiyatı yüksek bir ürün ya da hizmeti satın alınmaya karar verebilmesi durumudur. Böyle bir durumda, alıcı bilgiye karşı çok duyarlıdır ve iyice araştırır. Kişiliği ve mali durumu satın alma niyeti üzerinde etkili olur. Daha önce az ya da çok satın alma tecrübesi olmadığı için belirli markalara bağlılık durumu gelişmemiştir. Öncelikle yeni grubunu kavrayabilmek ister ve sonradan marka seçimi için kriter belirlemeye çalışır. 


\subsection{Tüketici Davranışını Etkileyen Faktörler}

Farkl1, kültür, sosyal sınıf, kişisel ve psikolojik özelliklere sahip hiçbir tüketici birbirine benzemez. Tüketicinin ürün ya da hizmet satın almasındaki, tüketici davranışını etkileyen faktörler Şekil 6'daki gibi özetlenebilir;

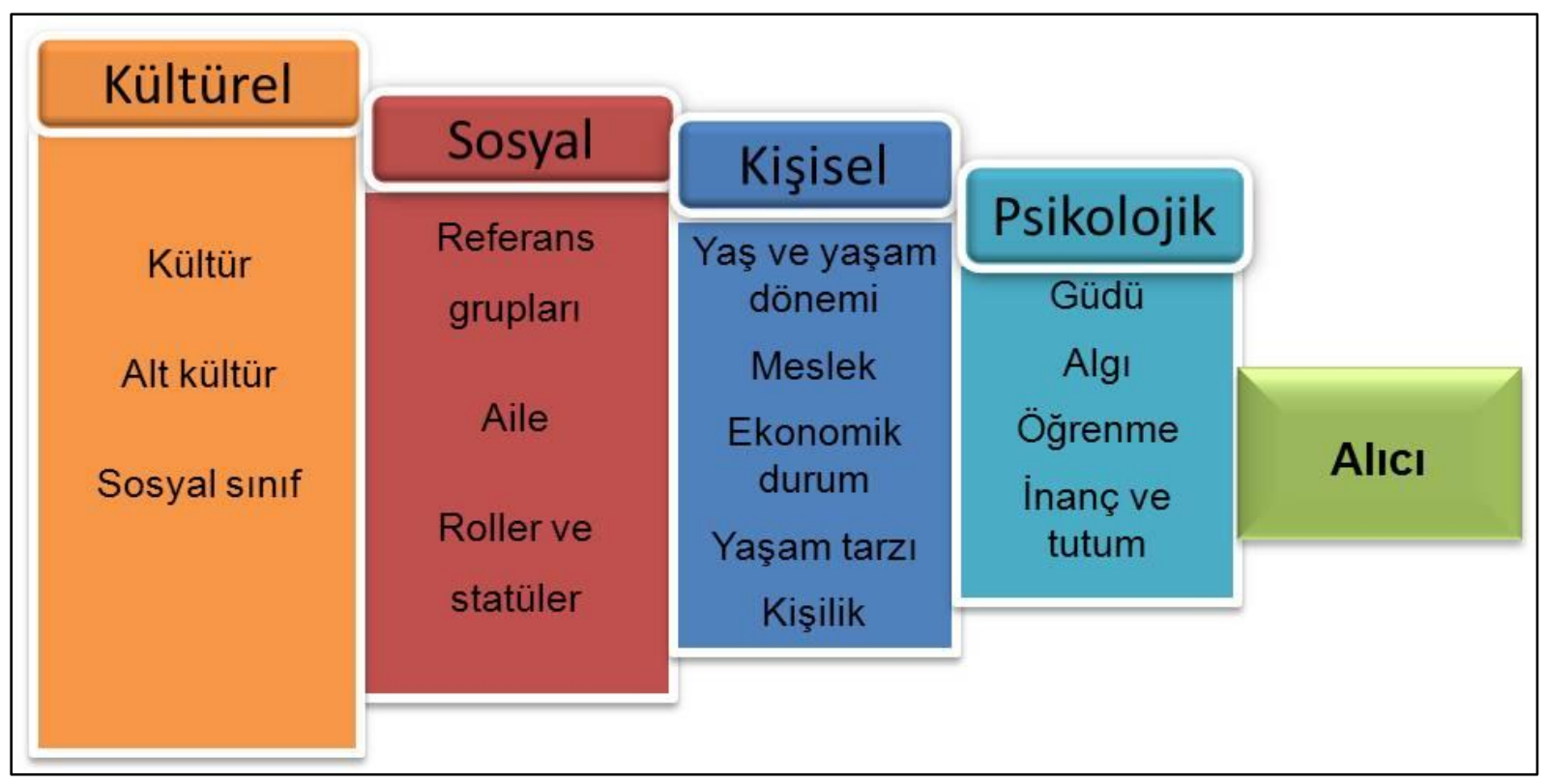

Şekil 6: Tüketici Davranışını Etkileyen Faktörler

Kaynak: KOTLER Philip ve AMSTRONG Gary Principles of Marketing, Prentice Hall College Div, 2005. - Cilt 11th. Edition, s:138

\subsubsection{Kültürel Faktörler}

Kültürel faktörler; kültür, alt kültür ve sosyal sınıf bileşenlerinden meydana gelmektedir.

Kültür: Kültür; toplumun üyesi olan kişinin, aile ya da diğer önemli kuruluşlardan (okul gibi) öğrendiği davranışlar, istekler, algılar ve temel değerlerden oluşmaktadır (KOTLER, et al., 2005 s. 137).

Kültür toplumdaki kişilerin davranışlarını bir düzene koymaya yardımcı olan, sonradan öğrenilmiş inançların, değerlerin, adetlerin, gelenek ve göreneklerin tümüdür (SCHIFFMAN, et al., 2000 s. 345).

Kültür, bireylerin oluşturduğu değerler sistemi ile ahlak, inanç, sanat, gelenek ve göreneklerin karışımıdır. Bireyin istek ve ihtiyaçlarının temel nedenidir. Bireylerin sürdürdügü faaliyetlerin tümü kültür tarafından yönlendirilir ve çoğu alımlar ya kişilerin 
temel ihtiyaçlarını gidermek, ya fiziksel bir konfor sağlamak (yürümek yerine araba kullanmak gibi) veya onların kültürel yaşamlarını oluşturan faaliyetlerini yürütmeleri amaciyla yapilır (ARSLAN, et al., 2000 s. 38).

Alt Kültür: Alt kültür; ortak yaşam deneyimine bağlı bir değer sistemini paylaşan insan grubudur (KOTLER, et al., 2005 s. 138).

Kültür, yaş, meslek, medeni durum, ulusal ve yerel bazlı etnik köken, coğrafi bölge, 1rk, din ve mezhep gibi birçok yönden kendi üyelerine özel bir kimlik veren birçok alt kültüre bölünebilir. O zaman alt kültürün tanımı "baskın toplumun önemli yanlarını koruyan, fakat kendi değer ve yaşam tarzlarını sağlayan herhangi bir kültürel modelleme" şeklinde yapılabilir (BERKMAN, et al., 1992 s. 156). Alt kültür kişi davranışlarının gelişmesinde önemli rol oynar.

Sosyal Sınıf: Prestij, güç ve gelir olarak benzer seviyelerde bulunan, inanç, tutum, davranışlar ve değerler hakkında yakın düşünen bireylerden oluşan gruba sosyal sınıf denmektedir. Sosyal sınıf, toplumdaki prestij ve gücün derecesine göre tüketicileri gruplandiran bir kavramdir (ASSAEL, 1998 s. 134).

Yani sosyal sınıf, toplum içinde bireylerin, gücünü ve prestijini belirleyen; meslek, eğitim seviyesi, gelir düzeyi gibi değişkenlere göre aralarında farklılıklar bulunmasına rağmen kendi içerisinde tabakalara ayrılmış homojen bir gruptur.

\subsubsection{Sosyal Faktörler}

Tüketiciler satın alma davranışlarında belirli grupları referans almaktadır. Tüketicilerin referans aldığ olabilmektedir. Bir çok insanın yaşam biçimi, içinde bulunduğu gruplarla benzerlik göstermektedir (SCHWARTZ, 1981 s. 86).

Referans (Danışma) Grupları: Tüketicinin satın alma kararı bir çok grup tarafından etkilenir. Burada birden çok gruptan etkilenmenin sebebi, bireyin ihtiyaçlarının tek bir grup tarafından karşılanamaması ve grupların kendi amaçları doğrultusunda uzmanlaşmış olmasıdır. Birey, kendi inançlarını, değer yargılarını ve fikirlerini ifade etmekte bu gruplardan faydalanır. Tüm bu sebeplerden danışma grupları, bireyin tutum ve belirgin davranışlarına şekil verdiği farz edilen bakış açısını oluşturan kişiler topluluğu olarak tanımlanabilir (BERKMAN, et al., 1992 s. 153). 
Referans grupları, kişi gruba uymak istediği için kişinin tutumunu ve kendine ilişkin görüşlerini etkiler. Kişiye yeni yaşam stilleri gösterir (ERP Akademi). Örneğin motosiklet kullanıcıları, efsane markası Harley Davidson'1, sadece bir motosiklet markası olarak değil, bir felsefe olarak düşünmektedirler ve böylece yaşam stillerini bu felsefeye göre belirlemeye çalışmaktadırlar.

Aile: Kan bağı, evlilik veya evlat edinme sonucu iki veya daha fazla kişinin beraber aynı çatı altında yaşamaları sonucu oluşan birlikteliktir (SCHIFFMAN, et al., 2000 s. 234). Aile; çekirdek aile ve geniş aile olmak üzere ikiye ayrılır. Önemli etkiye sahip tüketici karar alma örgütüdür. Birey ailesinden kazandığı dini, politik ve ekonomik anlayışlar çerçevesinde satın alma sürecini yaşayacaktır (KILIÇ, et al., 2004 s. $62)$.

Aile unsuru satın alma davranışını gözle görülür bir şekilde etkilemektedir. Örneğin çocuklu aileler çocuklarının isteklerine göre alışveriş alışkanlıklarını değiştirmektedirler. Ya da tüketiciler satın alma kararı verirken, aileden bir kişinin tavsiyesi ile olumlu ya da olumsuz bir şekilde satın alma kararını verebilmektedirler.

Rol ve Statüler: Kişilerin katıldıkları aile, kulüp, dernek gibi grupların her birindeki konumu, rol ve statü açısından ele alınabilir. Örneğin bir bayan, ebeveynleri açısından onların kızı rolünde, çalıştığı yerde ise ürün yöneticisi rolündedir. Bu rollerin her biri satın alma davranışını etkiler. Her rolün toplumda belirli bir statüsü vardır. Ürünler sosyal siniflara, coğrafi duruma ve hatta zamana göre statü sembolü olarak görev yapabilirler. Ellili ve altmışlı yıllarda Türkiye'de kot giymek, Amerikan sigarası içmek bir statü olmuştur (TEK, 1997 s. 203).

\subsubsection{Kişisel Faktörler}

Yaş, meslek ve ekonomik durum, yaşam tarzı ve kişilik; kişisel faktörleri oluşturur.

Yaş: Tüketicinin önemli demografik özelliklerinden biri olan yaş, satın alma kararını büyük ölçüde etkilemektedir. Yaş, aynı zamanda tüketicileri bir takım alt kültürlere bölen bir unsurdur. Örneğin "yaşlılar için” ibaresiyle sağlıklı yaşam ve diyet ürünleri satılmakta ya da "çocuklar için" ibareli ürün ve hizmetlerle, tüketiciler yaşlarına göre segmente edilmektedir. Pazarlamacılar hedef pazarlarını genellikle bu aşamalara göre tanımlarlar ve ona göre uygun ürünler ve pazarlama planları geliştirirler (TEK, 1997 s. 204). 
Ekonomik Durum ve Meslek: Bir kişinin ürün seçimini ekonomik durumu etkilemektedir. Meslek ise kişinin öğrenim düzeyinin bir göstergesi olabilmektedir. Meslek, tüketicinin satın alma kararını farklılaştıran önemli bir unsurdur. Ekonomik durum, özellikle pahalı ürünlerde daha da önem kazanmaktadır. Pazarlamacılarda ülkedeki ekonomik durum göstergelerine göre, ürün tasarımlarında, fiyatlandırmada ve ürün konumlandırmada değişiklikler yapmaktadırlar. (KOTLER, et al., 2005 s. 145)

Yaşam Tarzı: İnsanlar aynı sosyal sınıf, alt kültür ve hatta aynı meslekten gelseler bile çok farklı yaşam tarzlarına sahip olabilirler. Yaşam tarzı bir yandan kişinin sosyal sınıfını, diğer yandan da kişiliğini yansıtır. Kişinin yaşam tarzı onun faaliyet, ilgi, fikir ve seçimlerinde anlam bulan bir yaşam tarzıdır (KOTLER, et al., 2005 s. 146). Yaşam tarzının belirlenmesinin birçok avantajı bulunmaktadır. Benzer yaşam tarzlarını benimseyenler benzer tüketim davranışları içine girerler.

Kişilik: Herkesin kendine göre bir kişiliği, bir iç yapısı vardır. Karabulut'a göre kişilik, bir kişiyi diğerinden ayırmaya yarayan ve onun iç ve diş bütün özelliklerini bünyesinde bulunduran kendine özgü bir sistemdir (KARABULUT, 1989 s. 124). Bir diğer tanıma göre ise kişilik, bir insanı diğer insanlardan ayıran özel ve tipik davranışlar bütünüdür.

Kişilik, davranış kalıplarını birbirinden ayıran, düşünce ve duyguları içeren ve bireylerin çeşitli durumlara yönelik adaptasyonlarında her bir bireyi karakterize eden bir kavramdir. (ELDEN, et al., 2005 s. 224-230).

Tüketicinin seçimlerini belirleyen en önemli iki etken satın alanın kişiliği ve ürünün özelliğidir. Tüketici davranışları kişilik özelliklerine göre; alışkanlıklarına bağlı belirli markaları seçen tüketici, rasyonel seçime fiyatı esas alan tüketici, malın seçiminde fiyatı esas alan tüketici, ani karar veren, fiziksel çekiciliğe kapılan ve markaya daha az önem veren tüketici, duygusal davranan tüketici olarak gruplandırılabilir. (BAYRAKTAR, 1989 s. 34)

\subsubsection{Psikolojik Faktörler}

Psikolojik faktörler; güdülenme, algılama, öğrenme, tutum ve inançlar bileşenlerinden oluşur. 
Algılama: Dış dünyadaki soyut veya somut nesnelere ilişkin olarak alınan duyumsal bilgi algılamadır. Algılama, herhangi bir olayı, nesneyi, ilişkiyi görmek, duymak, tatmak, koklamak, dokunmak ve hissetmektir. Bu bağlamda, algılama insanın fizyolojik bir özelliğiymiş gibi gözükse de aslında algılama bireyin inançlarından, tutumlarından, kişilik özelliklerinden vb. diş etkilerden kontrol edilip yönlendirilebilen sosyal ve psikolojik bir olgudur (İNCEOĞLU, 2000 s. 40-45). Birey, kendi dünya görüşüne, inançlarına, değer yargılarına göre algılamaktadır (ÖZER, 2009 s. 3).

İnsanlar sürekli olarak çevrelerini araştırmaya, tanımaya, öğrenmeye ve anlamaya programlanmıştırlar. Algılama insanların beş duyusu aracılığıyla çevrelerini anlamaya çalışma sürecidir. Duyu organlarımız birer bilgi toplayıcı olarak çalışırlar ve çevremizi tanımamız, algılamamız ve öğrenmemiz için bilgi toplarlar (ÖZER, 2009 s. $3)$.

Algı kişinin bilgi süzgecinden geçerek farkındalık sağlar. Yani hislerimize birçok bilgi ulaşır. Fakat bunlardan ancak bazıları dikkat çekmektedir. Kişi bazı bilgileri seçip dikkate alırken, diğerlerini dikkatinden kaçırır. Bu duruma "seçici maruz kalma" denilmektedir. Bu bağlamda kolayca algılamamızı sağlayan unsurlar vardır; beklenilen bir olay, ihtiyaç ve bilginin yoğunluğu. Yani, tüketici bir olayı bekliyorsa, herhangi bir ürüne ihtiyacı varsa, ya da karşısına sürekli tekrarlanan reklamlar çıkıyorsa, farkındalığının daha yüksek olma olasılığı $\operatorname{artar}$ (HATİBOĞLU, 1993 s. 40).

Reklama yönelik algı: Belirli bir reklamın algılanabilmesi için ilk şart, izleyicinin reklama maruz kalmasıdır. Fakat sadece maruz kalmak yeterli değildir. Reklama yönelik algı oluşumunda; reklamın özellikleri kadar, izleyicinin genel olarak reklama ve içinde yer aldığı medyaya yönelik izlenimi önemli rol oynamaktadır (ÖZER, 2009 s. 4).

Kişinin çevresindeki çeşitli uyarıcıları duyu organları ile tanıması algılama olarak adlandırılır. Algılama iki yönlü bir süreçtir; hem güdüler, tutumlar algılamayı etkiler, hem de algılama güdüleri ve tutumları etkiler (ÖZDEN, 1978 s. 14).

Güdülenme (Motivasyon): Güdü için kişinin içinde bulunan ve bunu bir amaca yöneltecek enerji veren bir kuvvettir diyebileceğimiz gibi (HATİBOĞLU, 1993 s. 40), kişinin tatmin etmeye çalıştığı uyarılmış ihtiyaçlarıdır da diyebiliriz. 
Pazarlama açısından güdüler; duygusal güdüler ve mantıksal güdüler şeklinde ikiye ayrılır. İkincisi kişiyi bir ürünün sağlamlık, dayanıklılık gibi gözlenebilir veya ölçülebilir özelliklerini ön planda tutarak satın almaya sevk ederken; duygusal güdüler, prestij, ün, beğenilme gibi özellikleri öne çıkarırlar. (MUCUK, 2001 s. 72-73)

Güdüleri anlayabilmek için ihtiyaçlara bakılması gerektiğini öne süren Abraham Maslow, insanın, ihtiyaçları içinde onda en çok gerilim ve rahatsızlık yaratandan en azından doğru olanları karşılamak için bir sıra takip ettiğini savunmaktadır. Alt sıradan üst sıraya gidildikçe önceliği azalan bir ihtiyaçlar hiyerarşisini Maslow bu şekilde belirtmektedir.

Maslow’un, ihtiyaçların kapsamını vurgulayan motivasyon teorisine göre; insan devamlı olarak karşılanmamış ihtiyaçları bulunan varlıklar olarak karakterize edilmekte ve bu ihtiyaçların kendi aralarında hiyerarşik bir düzen içinde bulunduğu savunulmaktadır. $\mathrm{Bu}$ hiyerarşide, düşük seviyedeki ihtiyaçların karşılanması yüksek seviyedeki ihtiyaçlara oranla daha önceliklidir. Verilen ihtiyaçlar hiyerarşisi tüketici satın alma davranışlarında doğrudan etkili olmaktadır.

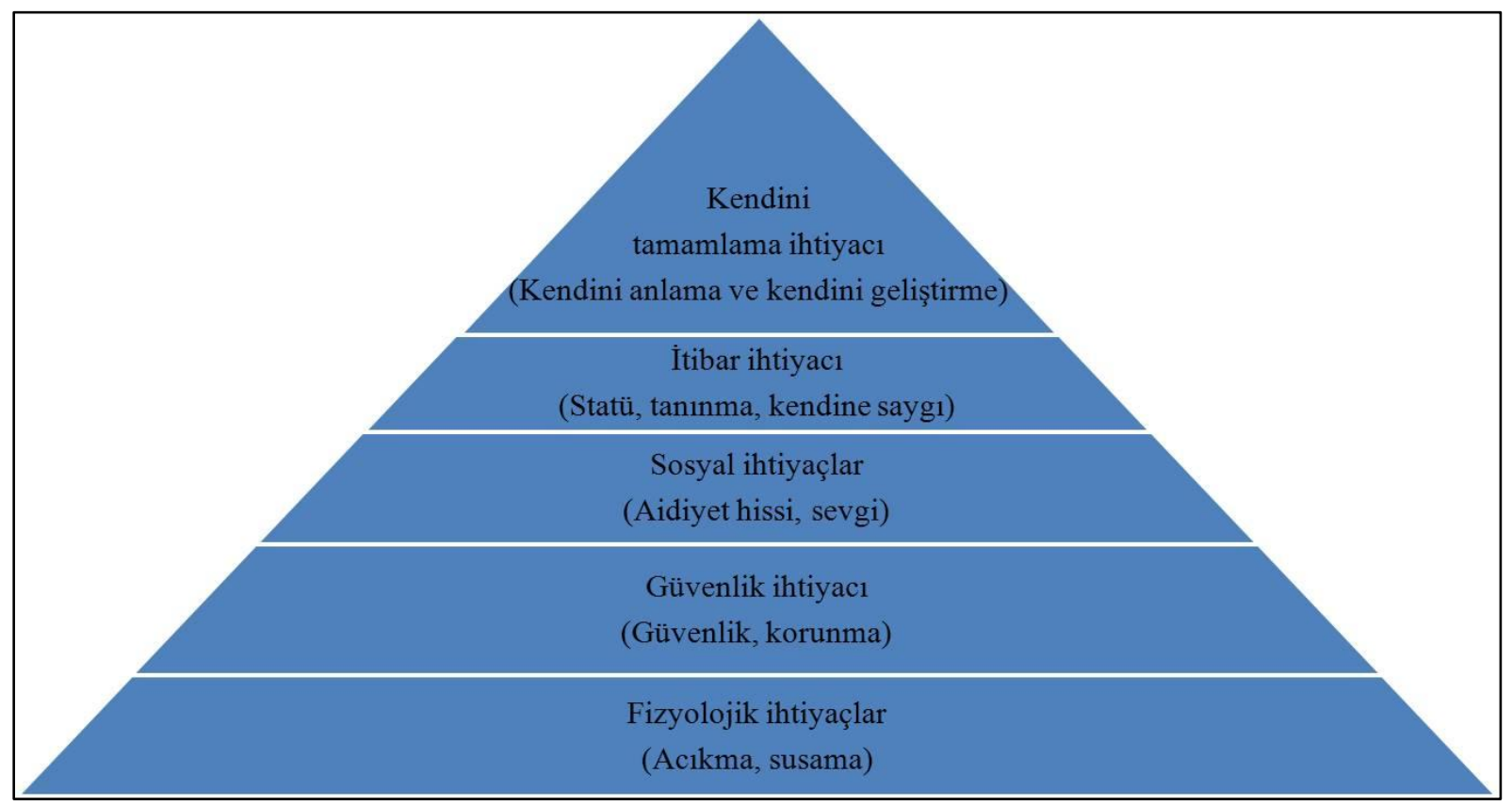

Şekil 7:Maslow'un İhtiyaçlar Hiyeraşisi

Kaynak: KOTLER Philip ve AMSTRONG Gary Principles of Marketing, Prentice Hall College Div, 2005. - Cilt 11th. Edition, s:151

Ö̆̆renme: Öğrenme; kişinin, yaşadıkça artan bilgi ve tecrübesinden yararlanarak davranışlarında gösterdiği kalıcı değişikliklerdir (SCHIFFMAN, et al., 2000 s. 192). Karabulut'a göre ise öğrenme, tepki eğilimlerindeki değişmelerden çok, 
tecrübeden dolayı davranıştaki veya tepkilerdeki değişmedir (KARABULUT, $1989 \mathrm{~s}$. $155)$.

Tüketiciler, algılama sürecinde çevrelerindeki uyarıcılar yardımıyla ürünler, reklamlar ve öbür tüketicilerden çeşitli bilgiler derlemektedir. Tüketicinin zihninde değerlendirdikten sonra biriktirdiği bu bilgiler, daha sonra kişilerin kararlarında, dolayısıyla satın alma davranışlarında etkili olmaktadır. (KARALAR, 2005 s. 63-82)

$\mathrm{Bu}$ bağlamda pazarlama açısından öğrenme, bireyin gelecekteki benzer davranışlarını yönlendiren, satın alma ve tüketime ilişkin bilgileri ve deneyimleri kazandıkları bir süreçtir. (SCHIFFMAN, et al., 2000 s. 192) Edinilen tecrübeler de ürünü kullanma, alışveriş yapma veya reklamlardan haberdar olma ile oluşarak tüketicilerin alışkanlıklarını etkiler.

Öğrenme sürecinin sonunda ürün veya hizmet ile ilgili olumlu bir alg1 yaratıldıysa tüketici alışveriş esnasında -alternatifleri değerlendirme ve seçim yapma aşamalarını atlayıp- o ürüne/hizmete yöneleceklerdir. (ZALTMAN, 2004 s. 33-34)

Pazarlamacıların satış aşamasında başarılı olabilmeleri için, alıcıların aldıkları ürünü/hizmeti öğrenmesini sağlamaları gerekmektedir. Alıcılar ürünü kullanarak, satıcılardan, reklamlardan, arkadaşlardan veya ailesinden öğrenebilmektedir. (HATİBOĞLU, 1993 s. 42)

Tutum ve Ínançlar: Tutum; kişinin kimi nesnelere ya da düşüncelere karş1 olumlu ya da olumsuz bilişsel değerlemeleri, duyguları ya da eğilimleridir. Düşünme sürecini ve duyguları içerir. İnançları etkiler, inançlar da davranışları etkiler. (AKIN, 2003 s. 30)

Kotler'e göre ise tutum, kişilerin bir obje ya da fikir hakkındaki, değer yargılarının, hislerinin, eğilimlerinin tümüdür. (KOTLER, et al., 2005 s. 153)

İnanç ise, kişinin bir şeyler hakkında sahip olduğu tanımlayıcı düşüncelerdir. (KOTLER, et al., 2005 s. 152) Tek’e göre ise inanç, kişinin herhangi bir şey hakkındaki tamamlayıcı düşüncesidir. (TEK, 1997 s. 211)

İnançlar gerçek, kulaktan dolma ve duygusal olabilir. Ürün ve hizmetlerle ilgili inançlar "ürün ve marka imajı”nı oluştururlar. Pazarlama yöneticileri bu nedenle inançları değiştirmeye çalışırlar. Buna karşılık tutum, kişilerin bir fikir veya nesneye 
karşı daha kalıcı (olumlu ya da olumsuz) değerlendirme, yaklaşım ve eylemleridir. Tutumlar tüketicileri belirli uyaranlara karşı tutarlı davranmaya yönelterek, onları her şeyi yeniden yorumlama zahmetinden kurtarmaya yararlar. Dolayısıyla tüketiciler tutumlarını kolay kolay değiştirmek istemezler. Bu bölümde tutum daha detaylı olarak incelenecektir.

\subsubsection{Tutum ve Reklama Yönelik Tutum}

\subsubsection{Tutum Kavramı ve Tüketici Davranışları Açısından Tutum Oluşturma}

Tutum, kişinin nesne, kanı ya da ortamlara yönelik olumlu ya da olumsuz bir biçimde tepkide bulunma eğilimidir. Kişilerin oluşturdukları tutumların, onların satın alma kararlarında doğrudan etkileri olduğu açıktır. Satın alma kararı da belirli bir tutumun pekiştirilmesini veya değiştirilmesini etkiler. Eğer pazarlamacılar, farklı pazar bölümlerinin ürünlere ve markalara yönelik tutumlarını belirleyebilirlerse, bu tutumlardaki değişmeleri ölçebilirlerse, pazarlama stratejisinde bunları daha iyi yorumlayıp kullanabilirler. (ODABAŞI Yavuz, 1996 s. 157)

Tutumlar gözlenemezler. Fakat gözlenebilen ve incelenebilen davranışları ortaya çıkartırlar. $\mathrm{Bu}$ nedenle, tutumu oluşturan bileşenleri incelemek gerekmektedir. Tutum üç bileşenden oluşmaktadır;

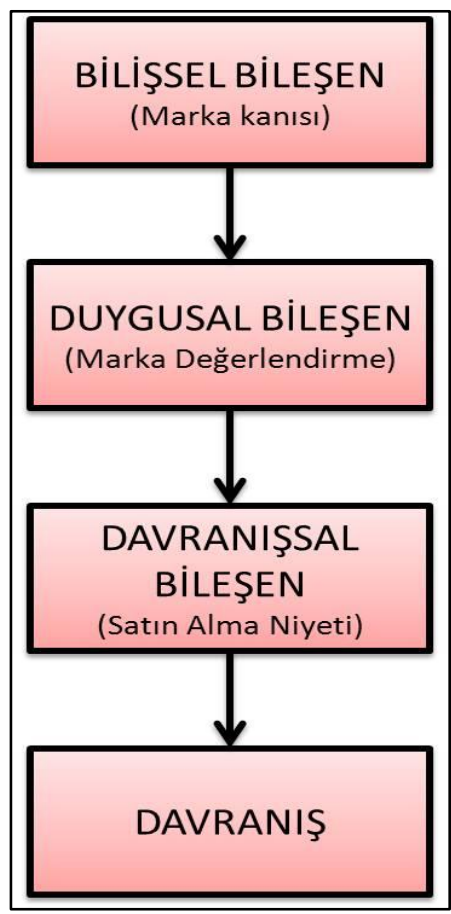

Şekil 8: Tutum Bileşenleri

Kaynak: ASSAEL Henry Consumer Behavior and Marketing Action, South-Western Pub, 1998. - Cilt 6th. s283 
Bilişsel bileşen, kişinin bir nesneye yönelik düşünce, bilgi ve inançlarını oluşturur. Tutuma konu olan nesne hakkında kişinin tüm inançlarını kapsar ve doğru ya da gerçek olmaları gerekmez. Ancak bilgiler ne kadar durumunda gerçeğe dayanırsa o kadar kalıcı olur. Bilişselliğin değişmesi durumunda tutum da değişir. Tüketicinin ürün, marka özellikleri ve mağazanın sunduğu hizmetler hakkındaki inançları ve bilgileri bilişsel bileşeni oluşturur (BLYTHE, 2001 s. 42).

Duygusal bileşen, kişinin bir nesneye yönelik duygusal tepkileridir ve duyguları içerir. Bilişsel bileşene göre daha basit yapıdadır ve kişinin değerleri ile ilişkilidir. Kişi, bir nesneyi olumlu yada olumsuz olarak değerlendirip ona göre duygular besler (BLYTHE, 2001 s. 42).

Davranışsal bileşen ise, tutumun konusuna yönelik belirli bir davranış eğilimidir. Diğer iki bileşene uygun olarak hareket etme eğilimini yansıtır. Eylem yönlüdür. Davranışsal bileşen, bir eğilimi yansıtır ve belirli bir yönde davranma niyeti söz konusudur. Ancak kişinin her zaman bu niyete göre davranması gerektiğini beklemek hatalı olabilir ve araya giren faktörler kararı etkileyebilir (BLYTHE, $2001 \mathrm{~s}$. $42)$.

Tüketici davranışları açısından tutum oluşturma süreci incelendiğinde ilk alternatif, önce bilişsel bileşene hitap ederek tutum yaratma stratejisidir. Ürünün fonksiyonel yararlarının büyük olması ve rakiplere gerçek anlamda fark yaratılması halinde ya da ürünün yepyeni bir ürün olması durumunda çoğunlukla bilgilendirme ile bilişsel bileşenden başlayan bir tutum geliştirme süreci izlenir. Ancak yapılan bazı araştırmalarda bu doğrusal akışın her zaman gözlemlenmediği ortaya çıkmıştır. (BODUR, et al., 2000 s. 17-28) Pazarlamada tutum bileşenlerinin bu sırayı izlemediği en belirgin uygulama, örnek ürün dağıtımlarıdır. Örnek ürünün denenmesi davranışı, ürüne yönelik duygusal bileşen oluşturma ve bunu ise bilişsel bileşen oluşturma adımları izler. Yapılan araştırmalar, tüketicilerin ürünü denemişlerse daha güçlü tutumlar geliştirdiklerini göstermektedir (KEMPF, 1999 s. 35-50). Ürüne ve hizmete yönelik olumlu duygular geliştiren tüketiciler ürünü satın aldıktan (davranış) sonra, ürünün ambalajını ya da etiketini okuyup bilişsel bileşeni oluşturabilir. Diğer yandan tüketicilerin plansız satın almalarını arttırmak için izlenen mağaza içi düzenlemeler, indirim günleri gibi stratejilerde, tüketiciler satın alma anında düşünmeye ve hemen alış yapmaya özendirilirler. 
Pazarlamada kullanılan bir başka tutum geliştirme alternatifi ise tüketiciyi önce eyleme özendirmek ve eylemin doğacak sonuçları için onu rahatlatmaktır.

Tutum geliştirmek için bu süreçte izlenen aşamalar ne olursa olsun, istenilen tutumun gelişmesi için en önemli unsur bileşenler arasındaki tutarlılıktır. Pazarlama stratejisi açısından, ancak bileşenler birbirleri ile tutarlılık gösterdiği takdirde tüketici ürün, marka, mağaza hakkında olumlu duygu ve inanç oluşturup, olumlu tepkiler verir. Tutum ile satın alma süresi arasındaki zaman dilimi de tutumun tutarlı bir davranış yaratması bakımından etkilidir. Bu bağlamda reklamcılar mal ve ya hizmeti sundukları reklam çalışmalarında zaman öğesini oldukça dikkatli kullanmalıdır. Tutum davranış açısından değerlendirildiğinde bir diğer önemli unsur da "farkındalık yaratmak" olarak karşımıza çıkmaktadır. Farkındalık kişilerin kendi tutum ve davranışlarının ne ölçüde farkında olduklarını belirtmek için kullanılır.

\subsubsection{Reklama Yönelik Tutum}

Reklam yoluyla ürün özelliklerinin yada hizmet çeşitliğinin tüketici üzerinde oluşturacağı tutumlar satın alma sürecinde aktif rol oynamaktadır. Bu bağlamda tanımı yapıldığında; reklam tutumu, "belli bir reklama maruz kalındığında reklama karşı olumlu ya da olumsuz tarzda tepki verme eğilimi” olarak tanımlanmaktadır. (MacKENZIE, et al., 1986 s. 130)

Bir bireyin reklama yönelik tutumu, genel olarak reklamı beğenme ya da beğenmemek üzerine kurulmuş, öğrenilmiş bir davranıştır. Yapılan araştırmalara göre, reklam mesajını beğenen, seven ve bu mesaja yönelik olumlu tutumu olan kişilerin, reklama konu olan markaya karşı olumlu bir tutum geliştirme ve satın alma niyeti taşıma olasılıkları oldukça yüksektir. (SADIKOVA, 2006 s. 24-25)

Reklam tutumu markaya karşı tutum ve satın alma niyetini de ekleyerek, reklamın başarılı olup olmamasında önemli bir rol üstlenmektedir. (MacKENZIE, et al., 1989 s. 48-65)

Tutum kavramını açıklarken de değindiğimiz gibi, günümüzde yaygın olarak kabul gören görüşe göre tutum; bilişsel, duygusal ve davranışsal olmak üzere üç temel bileşenden meydana gelir. Bilişsel bileşen bir objeye ait bilgi ve inançların değerlendirmesini; duygusal bileşen bir objeye ilişkin hisleri; davranışsal bileşen ise objeye yönelik olarak istekle oluşan hareketi belirler. 
Bazı kaynaklara göre genel tutum modellerinde bilişsel, duygusal ve davranışsal olmak üzere üç boyut kabul edilirken, bazı tutum modellerinde ise sadece bilişsel ve duygusal olarak iki boyuttan söz edilmektedir. Reklam tutumu ise bilişsel ve duygusal elemanların (Shimp,1981) bir kombinasyonunu ifade etmektedir. (ÇAKIR, et al., 2007 s. 40)

Reklam tutumunun sadece duygusal bir yapı olarak tanımı; belirli bir reklama maruz kalındığında reklama karşı olumlu ya da olumsuz tarzda tepki verme eğilimi olarak yapılmıştır. (MacKEZIE, et al., 1983 s. 532-539) (MacKENZIE, et al., 1986 s. 130-143) (MacKENZIE, et al., 1989 s. 48-65)

Reklam tutumunun duygusal ve bilişsel boyutundaki tanımda ise bilişsel ve duygusal boyut ayrı ayrı incelenmiştir. Bilişsel boyutta, reklamın özelliklerine dair tüketicilerin yaptığg değerlendirmeler ele alınırken, duygusal boyutunda, tüketicinin sevgi, sevinç, üzüntü, nostalji gibi duygusal tepkileri ele alınmaktadır. (ÇAKIR, et al., 2007 s. 39-40)

Shimp (1981)'e göre de reklam tutumlarının duygusal ve bilişsel olmak üzere iki boyutu vardır. Duygusal boyut, reklama maruz kalma esnasında reklamın kişilere yaşattığı duygulardır. Örneğin reklam sayesinde eğlenmek, bıkkınlık duymak, sinirlenmek, harekete geçme isteği duymak vb. Bilişsel boyut ise kişilerin reklama maruz kalma esnasında reklam özellikleri hakkındaki yargıları, çıkarımları, tanımlamalarını ifade eder. Reklam tutumunun duygusal boyutunda, hedef kitlede ilgili markaya ilişkin çeşitli duygular oluşturularak reklama konu olan marka ile tüketici arasında duygusal bir bağ yaratılmaya çalışılır.

Reklam tutumunun bilişsel öğesini; nesne, kişi ya da konunun karakteristiğindeki inançlar ile bilgi oluştururken, duygusal öğesini; insanların reklama öznel olarak yaklaşımları belirler. Örneğin reklama yönelik "hoş”, “güzel”, "sevdim", "sevmedim" gibi ifadeler duygusal boyutu oluşturmaktadır. (FRANZEN, 2005 s. 46) ayrıca bu aşamada tüketicide farkındalık yaratılarak, bilgilendirme sağlanır.

Ayrıca Ducoffe'a göre, reklam tutumunun bilişsel öğesini, reklam değeri oluşturur. Reklam değeri ise, "tüketicilerin reklamın yararlılığına ve değerine ilişkin sübjektif değerlendirmeleridir.” şeklinde tanımlanmaktadır. (DUCOFFE, 1995 s. 1) Yine Ducoffe'a göre reklam değerinin dört öncülü vardır. Bunlar; bilgilendiricilik, 
eğlendiricilik, rahatsız edicilik ve aldatıcılıktır. $\mathrm{Bu}$ faktörler tüketicilerin reklama verdiği değeri belirler.

Bilgilendiricilik: Tüketicinin nihai kararı verebilmesi için ilk aşama, iç ve dış kaynakları kullanarak bilgi aramasıdır. İç kaynaklar; geçmişte yaşanılan deneyimler vb. kişinin zihnindeki bilgi birikimini ifade ederken, dış kaynaklardan biri reklamlardır. Eğer tüketicinin zihninde ürün yada hizmetle ilgili herhangi bir bilgi yoksa, bu durumda daha çok reklamlara dikkat eder.

Tüketiciler işlerine yarayacak bilgileri elde etmek isterler ve bunun sonucunda reklama yönelirler. Bilgilendirici reklamlar ise tüketici tatminini ve imaj arttırmayı hedefleyen bilgilendirme kampanyalarının bir parçası olabilmektedirler. Bilgilendirici reklamlar ikna edici, ilgi çekici ve etkili reklamlardır (ÇAKIR, et al., 2007 s. 40-41)

Ĕglendiricilik: Vorderer'e göre eğlence, medya kullanıcılarının günlük yaşantılarında, bazen sıkıcı anlarındaki zevk arayışı, kötü durumlarda telafi arayışı, yetersiz bir durumda doyum, bazense kendini geliştirme, hatta kendini kanıtlama şeklinde tanımlanmaktadır. (VORDERER, 2001 s. 258) Bu bağlamda Boshart ve Macconi’ye göre izleyici açısından eğlencenin içeriği şu şekilde sınıflandırılmaktadır; telafi, doyum-ihtiyaçların karşılanması, kendini kanıtlama ve hayallerini serbest bırakma imkânı tanıması. (BOSSHART, et al., 1998 s. 3-4)

Ducoffe'a göre reklamın hangi yayın organında olduğu, reklama yönelik algıyı etkilemektedir. $\mathrm{Bu}$ bağlamda televizyon eğlendirici bir medya aracı olarak kabul edilmekte ve burada yer alan reklamlar daha eğlendirici olarak algılanmaktadır. (DUCOFFE, 1995 s. 1-18)

Rahatsız edicilik: Genel anlamda düşünüldüğünde televizyon reklamları, izleyicinin isteği dışında önüne gelen, mekânına zorla giren reklamlardır ve bu yüzden rahatsız edici ya da sinirlendirici olabilmektedir. İzlenilen bir programın ya da dizi filmin arasında gösterilen bir reklama tüketici zorla maruz kalabilmektedir.

Bu bağlamda rahatsız edici ya da sinirlendirici reklam; kışkırtan, hoşnutsuzluk ve geçici sabırsızlık yaratan reklamlardır ve bu durum reklamın etkinliğini azaltmaktadır. (ÇAKIR, et al., 2007 s. 42) 
Aldatıcılı: Televizyon reklamları değerlendirilirken en büyük handikap "etik" olgusunda yaşanmaktadır. Tüketicinin güven duygusu “etik” olgulara bağlıdır.

Bu bağlamda; ürünün kalitesi ile ilgili abartılı reklamlar ve ağırlık, boyut, renk gibi ürünün objektif biçimde ölçülmesi mümkün özelliklerini bilerek yanlış gösteren hileli reklamlar yanıltıcı ya da aldatıcı reklamlar olarak değerlendirilmektedir. (ÇAKIR, et al., 2007 s. 42)

\subsection{Tüketici Davranışını Etkileyen Faktörler ve Infomercıal Reklamlar Üzerine Literatürde Yapılan Çalışmalar}

Tüketici davranışını ve satın alma kararını etkileyen faktörler üzerine yapılan literatür taraması

1986 yılında Sproles ve Kendall'ın tüketicilerin satın alma karar süreçlerini daha iyi anlayıp, davranışlarını öngörmeye yardımcı olmak amacıyla geliştirilen Tüketici Tarzları Envanteri; Türk tüketicisinin karar verme tarzını anlayabilmek için Kabadayı, Alnıaçık ve Dursun'un tarafından değerlendirilmiş ve orijinal TTE'deki sekiz temel karar verme tarzı ile benzerlik ve farklılıkları ortaya konulmuştur. Sproles ve Kendall'ın çalışmalarında tüketici karar verme özellikleri hem duygusal hem bilişsel anlamda incelenmiş ve sekiz temel ölçekle belirlendiği ortaya konmuştur. Türkiye'de yapılan bu uyarlama sonucunda, "mükemmeliyetçilik-yüksek kalite odaklılık, marka odakl11ık-fiyat=kalite bilinci, moda odakl1lık, fiyat odaklılık, düşünmeden dikkatsizce alışveriş, bilgi karmaşası yaşama, alışkanlık-marka bağlılığı odaklılık, alışverişten kaçınma, kararsızlık" faktörlerinden oluşan bir sonuç çıkmıştır. (KABADAYI, et al., 2010 s. 321-326)

Tüketicilerin alışveriş sırasında hissettikleri duyguların satın alma davranışı üzerindeki etkisini inceleme amacıyla Türk tüketicilerine yönelik yapılan çalışmada ise, Richins'in 1997 'de oluşturduğu tüketim duygu seti temel alınmıştır. Tüketim duyguları bağlamında; “ümitsiz, mutsuz, hoşnutsuz, isteksiz, kötü hissettiren, kızgın, huzursuz, sinirli, gergin, kaygılı, stresli, endişeli, hayal kırıklığı, tatminsizlik, sevmemiş, memnunsuz" ifadeleri ile ölçülmüştür. Analiz bulgularına göre, tüketim duygularının en etkili olduğu tüketici tepkisi, mağazaya tekrar gelem niyeti olarak belirlenmiştir. Bunu memnuniyet derecesi, mağazayı tavsiye etme ve harcama düzeyi takip etmektedir. $\mathrm{Bu}$ bağlamda ulaşılan sonuç, tüketicinin alışveriş esnasında hissettiği duyguların, alışveriş 
deneyimi ve bir sonraki satın alma davranışına ilişkin mağaza/marka tercihini etkilediğini göstermektedir. (ALTUNIŞIK, et al., 2010 s. 212-226)

Reklama yönelik halkın tutumunu belirlenmeye çalışıldığı, Shavitt, Lowrey ve Haefner'ın çalışmasında Amerikan halkının genellikle reklamları izlemeyi sevdikleri, bilgilendirici buldukları ve bu reklamların karar süreçlerinde onlara bir rehber oluşturduğu, reklamlara çok güvenmeselerde, satın alma kararları için reklamda güven unsuru aradıklarını ve yasal düzenlemeleri desteklemediklerini yer almaktadır. (SHAVITT, et al., 1998 s. 7-21)

\section{Doğrudan pazarlama üzerine yapılan literatür taraması}

Üretici tabanlı veya tüketici tabanlı içeriklerin yer aldığı internette ağıdan ağıza iletişim platformlarının farklı ürün gruplarındaki satın alma eğilimi üzerine yapılan çalışmada, tüketici tabanlı içeriğe sahip internet siteleri (yani hepsiburada.com ve tatil sepeti gibi) satın alma açısından daha yüksek bir etkiye sahip olduğu belirlenmiştir. Bunun nedeni olarak üretici tabanlı içerik sitelerinden tüketicilere her an bilgi bombardımanına tutmasıyla yaşanan bıkkınlık ve tüketicilerin kitle iletişim araçlarına duydukları güvensizliğe bağlanmıştır. (SCHNEIDER, et al., 2010 s. 344-354)

Bu bağlamda Sanaktekin ve Yeşilada'nın yaptıkları, doğrudan pazarlamanın unsurlarından olan internet üzerinden alışverişe karşı tutumu etkileyen psikolojik faktörler üzerine çalışmalarında, tutumun en önemli unsurunun güven olduğundan söz edilmektedir. $\mathrm{Bu}$ çalışmada güven öncülleri; algılanan risk, algılanan dürüstlük ve algılanan yetkinlik olarak kabul edilirken, kişilik özellikleri; güvene eğilim, dışadönüklük ve deneyime açıklık olarak tüketici güvenine etki ederek e-alışverişe yönelik tutumu belirlediği belirlenmiştir. Sonuç itibariyle, tüketicinin internet üzerinden alışverişe karşı tutumlarında risk algısı ve firmaya karşı algılanan dürüstlük önemli belirleyicilerdir. (SANAKTEKİN, et al., 2010 s. 637-639)

\section{Infomercial reklam üzerine yapılan literatür taraması}

Infomercial reklama yönelik yapılan ilk çalışmalarda, potansiyel (olası) müşterilerin karakteristik özellikleri üzerinde yoğunlaşılmış ve bu çalışmalar potansiyel müşterilerin sosyo-demografik yapısı ile ilgili sonuçlar vermiştir. Örneğin 1987 yılında James ve Cunnigham'ın ve yaptıkları çalışmalarında infomercial reklamlardan alışveriş 
yapanlar ile yapmayanların tutumsal, güdüsel, psikolojik ve sosyolojik karakteristiklerini belirlemek amaçlanmıştır. (JAMES, et al., 1987 s. 12-23)

Donthu ve Gilland'ın 1996 yılında yaptıkları çalışmalarında Infomercial reklamlardan alışveriş yapanlar ile yapmayanların demografik açıdan benzerliklerini, alışveriş yapanların daha fazla televizyon izlediklerini ve kolaylık arayışında, marka ve fiyat bilincinde, çeşitlilik arayışında, yenilikçi ve riski kabul eden kişiler olduğunu ortaya koymuşlardır. Ayrıca infomercial reklamlardan alışveriş yapanların reklama ve doğrudan pazarlamaya yönelik tutumları pozitifken, alışverişe karşı tutumlarının negatif olduğunu belirlemişlerdir. (DONTHU, et al., 1996 s. 69-76)

Yine 1996 yılında infomercial reklamlarda bilgi içeriğinin analiz edildiği çalışmalarında Elliot ve Lockard, diğer reklam türlerine oranla infomercial reklamlarda daha fazla bilgi unsuru bulunduğundan söz etmektedirler. Resnik ve Stern'in on dört maddelik ölçeğini kullandıkları çalışmalarındaki bulgulara göre, ürünün elverişliliği, tamamlayıcılık ve performansın bilgi unsuru olarak kullanıldığı belirlenmiştir. (ELLIOTT, et al., 1996 s. 44-56)

Agee ve Martin'in 2001 yılında yaptıkları çalışmalarında infomercial reklam tüketicisinin planlı olarak mı yoksa aniden mi alışveriş etmeye karar verdiklerini araştırılmaktadır. 878 infomercial reklam tüketicisi üzerinde ve 6 ürün kategorisi belirlenerek yapılan etkinlik çalışmasında, "yorum ve kanıtlar”, “ödeme bilgileri” "tanıma-karşılaştırma-ekstralar”, “ürün ile ilgili önceki ilgilenim”, "satın almadan önceki düşünce" faktörlerinden yararlanılmakta ve tüm bu faktörlerin satın alma kararı üzerindeki etkisi incelenmektedir. $\mathrm{Bu}$ çalışmada infomercial reklam tüketicisinin beklenenin aksine aniden karar vererek alışveriş etmediği görülmektedir. Yani planlı olarak alışveriş etmektedirler. Planlamanın ise infomercial reklamı sık sık izledikten sonra yapıldığg belirlenmiştir. (AGEE, et al., 2001 s. 35-41)

Yine Martin, Bhimy ve Agee'nin 2002 yılında yaptıkları çalışmalarında, infomercial reklamlardan etkilenerek ürün satın alan kişiler ile reklam etkinliği arasındaki ilişki ve etkilenme durumunu incelenmektedir. Bulgulara göre uzman yorumları, kanıtlar, ürün karşılaştırılması ve bonus ürün tekliflerinin tüketicileri etkilediği görülmektedir. Ayrıca yaş unsurunun infomercial reklamlardan ürün satın alan kişileri etkilediği belirlenmiştir. (AGEE, et al., 2002 s. 468-480) 
1997 yılında Wicks, bir istasyon yayınında infomercial reklam sayısını etkileyen faktörleri belirlemek amacıyla, çeşitli televizyon istasyonlarındaki çalışma sürecini anlamak ve yanlış yapılan infomercial reklamlar için televizyon yayınlarına yol göstermek için, Wicks ve Abernathy 2001 yılında, yanıltıcı reklamları önlemek amacıyla, infomercial reklamları düzenleyici unsurların belirlenmesi ve geliştirilmesi amacıyla, 2005 yıllında Wicks ve Warren çalışmalar yapmışlardır. (WICKS, 1997 s. 2938) (WICKS, et al., 2001 s. 41-54) (WICKS, et al., 2005 s. 95-105)

Geleneksel reklam, infomercial ve doğrudan deneyim, iletişim şekillerinin karşılaştırıldığı 2000 yılında Singh, Balasubramanian ve Chakraborty'nin yaptıkları çalışmalarında mesaj etkinliği ölçülmektedir. (BALASUBRAMANIAN, et al., $2000 \mathrm{~s}$. 59-74)

Görsel reklamlar ile doğrudan tepki reklamlarının 1980 yılında Woodsideve Motes, 1992 yılında ise Peltier, Mueller ve Rosen tarafından karşılaştırıldığı çalışmalar yapmışlarıdır. (WOODSIDE, et al., 1980 s. 31-38) (PELTIER, et al., 1992 s. 40-48)

Doğrudan tepki reklamlarındaki yaratıcı varyasyonlara, Motes, Hilton, Fielden 1989 yılında yaptıkları çalışmada tepkileri incelemişılerdir. (MOLTES, et al., 1989 s. 16-26)

Doğrudan tepki reklamlarına yapılan içerik analizi araştırmalarında, genel olarak bilgi içeriğinden söz edilmektedir. (JAMES, et al., 1989 s. 7-14) (JAMES, et al., 1990 s. 23-29) (BUSH, et al., 1990 s. 6-13) (LEBOURVEAU, et al., 1988 s. 25-34)

Chapman ve Beltramini'nin 2000 yılında yaptıklarında çalışmada, bir infomercial reklamın etkili olabilmesi için optimum süre belirlenmeye çalışılmıştır. (CHAPMAN, et al., 2000 s. 24-30) 


\section{BÖLÜM}

\section{INFOMERCIAL REKLAMLARIN SATIN ALMAYI \\ ETKİLEYEN FAKTÖRLER AÇISINDAN \\ DEĞERLENDİRILMESINE İLIŞKİN BİR \\ UYGULAMA}

\subsection{Araştırmanın Amacı}

$\mathrm{Bu}$ araştırmanın temel amacı, reklam içeriği, demografi, reklama yönelik algı, alıcının kişilik özellikleri ve televizyon izleme alışkanlıklarının infomercial reklama yönelik tutum açısından ve tutumunda satın alma kararı üzerindeki etkisi açısından incelenmektedir. Ancak ölçeğin Türkiye'de uygulanabilir bir ölçek olduğunun tespit edilmesi gerekmektedir. Bu sebeple önce ölçeğin Türkiye'de güvenilirliği ve geçerliliği araştırılmıştır.

\subsection{Araştırmanın Sınırlamaları}

$\mathrm{Bu}$ araştırmanın en önemli sınırlaması; anketi cevaplayanların televizyon izleyicisi olmalarıdır. Araştırmanın diğer bir kısıtlaması ise zaman ve maliyet kısıtlamasıdır. $\mathrm{Bu}$ nedenle araştırma kapsamı yalnızca İstanbul ili içerisinden oluşturulmuştur.

\subsection{Araştırmanın Türü ve Modeli}

Pazarlama araştırmaları amaçlarına göre, keşifsel, tanımsal ve nedensel araştırmalar olmak üzere üç grupta sınıflandırılmaktadır. Keşifsel (açıklayıcı) araştırma modelinde amaç, pazarlama probleminin tanımlanması veya keşfedilmesi yani alternatif hareket seçeneklerinin ve yeni hipotezlerin saptanmasıdır. Bu tür araştırmalarda belirli araştırma sorunlarını, araştırma değişkenlerini ve/veya bu sorunlara ilişkin araştırma hipotezlerini belirleyebilmek için gerekli bilgilerin toplanması amaçlanır (KURTULUŞ, 2004 s. 251)

Tanımsal araştırmalarda ise amaç, bir ana kütlenin ya da bir fenomenin özelliklerinin tanımlanmasıdır. Tanımsal araştırmalara bilgi ihtiyacı belirlendikten, tanımlandıktan ve hipotezler oluşturulduktan sonra başlanmaktadır. Nedensel 
araştırmalarda ise, değişkenler arasındaki neden sonuç ilişkisinin belirlenmesi temel amacı oluşturmaktadır (GEGEZ, 2005 s. 31)

Etkilerine göre hipotezler Kotler'in tüketici davranışını etkileyen kişisel ve psikolojik faktörlerden yararlanarak, Martin, Bhimy ve Agee (2002), Ducoffe (2005), Donthu ve Gilliland (1996) kaynaklarıyla oluşturulmuştur.

Araştırmanın hipotezleri ise şu şekildedir;

\begin{tabular}{|c|c|c|c|}
\hline Hipotez & Kaynak & Kabul & Red \\
\hline $\begin{array}{l}\mathbf{H}_{1} \text { : Infomercial reklam içeriğinin infomercial reklama } \\
\text { yönelik tutuma etkisi vardır. }\end{array}$ & $\begin{array}{l}\text { Martin, Bhimy, } \\
\text { Agee, } 2002\end{array}$ & $\sqrt{ }$ & \\
\hline $\begin{array}{l}\mathbf{H}_{2} \text { : Infomercial reklama yönelik algının infomercial } \\
\text { reklama yönelik tutuma etkisi vardır. }\end{array}$ & Ducoffe, 2005 & $\sqrt{ }$ & \\
\hline $\begin{array}{l}\mathbf{H}_{3} \text { : Alıcının kişilik özelliklerinin infomercial reklama } \\
\text { yönelik tutuma etkisi vardır. }\end{array}$ & $\begin{array}{l}\text { Donthu ve } \\
\text { Gilliland, } 1996\end{array}$ & $\sqrt{ }$ & \\
\hline $\begin{array}{l}\text { H}_{4} \text { : Infomercial reklam içeriğinin, algının ve alıcının } \\
\text { kişilik özelliklerinin infomercial reklama yönelik } \\
\text { tutuma etkisi ve tutumun da satın alma kararına etkisi } \\
\text { yoktur. }\end{array}$ & $\begin{array}{l}\text { Martin, Bhimy, } \\
\text { Agee, } 2002\end{array}$ & & $\sqrt{ }$ \\
\hline $\begin{array}{l}\text { H}_{5} \text { : Infomercial reklam içeriğinin infomercial reklama } \\
\text { yönelik reklama yönelik satın alma kararına etkisi } \\
\text { vardır. }\end{array}$ & Ducoffe, 2005 & & $\sqrt{ }$ \\
\hline
\end{tabular}

- Demografi ve televizyon izleme alışkanlıkları üzerine hipotezler, Donthu ve Gilliland'ın 1996 yılındaki, Cunnigham ise1987 yılındaki çalışmasından yola çıkılarak hazırlanmıştır.

- Her bir hipotezin $\mathrm{H}_{0}$ hipotezi anlamlı bir farklılık yoktur şeklindedir.

*Hipotezlerde $\mathrm{A}=$ cinsiyet, $\mathrm{B}=$ medeni durum, $\mathrm{C}=\mathrm{yaş,} \mathrm{D}=$ Çocuk sayısı, $\mathrm{E}=$ Aylık gelir, $\mathrm{F}=$ Haneye giren gelir, $\mathrm{G}=$ Eğitim, $\mathrm{H}=$ meslek olarak belirtilmiştir.

**Hipotezlerde $\mathrm{I}=$ saatlik televizyon izleme alışkanlıkları $\mathrm{J}=$ haftalık televizyon izleme alışkanlıkları olarak belirtilmiştir.

FARKLILIKLARINA GÖRE HIPOTEZLER

\begin{tabular}{|c|c|}
\hline Hipotez & Kabul \\
\hline \multicolumn{2}{|l|}{ Infomercial reklama yönelik algı } \\
\hline $\begin{array}{l}\mathbf{H}_{\mathbf{6}(\mathbf{A}, \mathbf{B}, \mathbf{C}, \mathbf{D}, \mathbf{E}, \mathbf{F}, \mathbf{G}, \mathbf{H})^{*}}: \text { Demografi ile bilgilendiricilik arasında anlamlı bir } \\
\text { fark vardır. }\end{array}$ & $\mathbf{H}_{6 \mathrm{~B}}, \mathbf{H}_{6 \mathrm{C}}$ \\
\hline 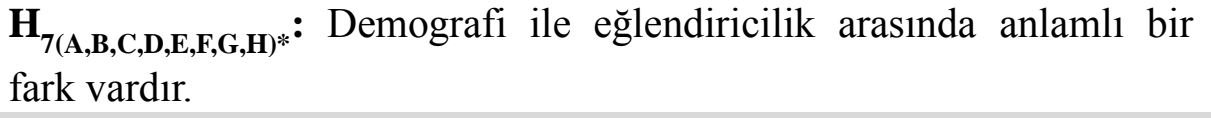 & $\mathbf{H}_{7 \mathbf{B}}$ \\
\hline $\begin{array}{l}\mathbf{H}_{\mathbf{8}(\mathbf{A}, \mathbf{B}, \mathbf{C}, \mathbf{D}, \mathbf{E}, \mathbf{F}, \mathbf{G}, \mathbf{H})^{* *}} \text { : Demografi ile aldatıcılık arasında anlamlı bir fark } \\
\text { vardır. }\end{array}$ & $\mathbf{H}_{\mathbf{8 B}}$ \\
\hline
\end{tabular}


$\mathbf{H}_{\mathbf{9}(\mathbf{A}, \mathbf{B}, \mathbf{C}, \mathbf{D}, \mathbf{E}, \mathbf{F}, \mathbf{G}, \mathbf{H}) *}:$ Demografi ile rahatsız edicilik arasında anlamlı bir fark vardır.

$\mathbf{H}_{\mathbf{1 0 ( I , J ) * *}}:$ Tv izleme alışkanlıkları ile bilgilendiricilik arasında anlamlı bir fark vardır.

$\mathbf{H}_{11(\mathbf{I}, \mathbf{J})^{* *}}$ : Tv izleme alışkanlıkları ile eğlendiricilik arasında anlamlı bir fark vardır.

$\mathbf{H}_{\mathbf{7}}$

$\mathbf{H}_{\mathbf{1 2 ( I , J ) * *}}:$ Tv izleme alışkanlıkları ile aldatıcılık arasında anlamlı bir fark vardir.

$\mathbf{H}_{\mathbf{1 3 ( I , J )})^{* *}}$ : Tv izleme alışkanlıkları ile rahatsız edicilik arasında anlamlı bir fark vardır.

\section{Alıcının kişilik özellikleri}

$\mathbf{H}_{\mathbf{1 4 ( A , B , C , D , E , F , G , H ) *}}:$ Demografi ile çeşitlilik arayışı arasında anlamlı bir fark vardır.

$\mathrm{H}_{14 \mathrm{C}}$

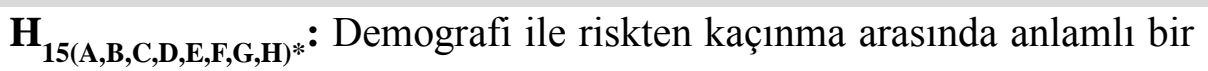
fark vardır.

$\mathbf{H}_{\mathbf{1 6}(\mathbf{A}, \mathbf{B}, \mathbf{C}, \mathbf{D}, \mathbf{E}, \mathbf{F}, \mathbf{G}, \mathbf{H})^{*}}:$ Demografi ile düşünmeden/fevri hareket etme arasında anlamlı bir fark vardır.

$\mathrm{H}_{15 F}, \mathrm{H}_{15 B}$

$\mathbf{H}_{\mathbf{1 7 ( A , B , C , D , E , F , G , H ) *}}$ : Demografi ile fiyat bilinci arasında anlamlı bir fark vardir.

$\mathbf{H}_{\mathbf{1 8 ( A , B , C , D , E , F , G , H ) *}}$ : Demografi ile marka bilinci arasinda anlamlı bir fark vardır.

$\mathbf{H}_{\mathbf{1 9 ( I , J ) * *}}$ : Tv izleme alışkanlıkları ile çeşitlilik arayışı arasında anlamlı bir fark vardır.

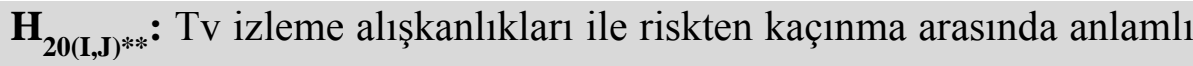
bir fark vardir.

$\mathbf{H}_{\mathbf{2 1 ( I , J ) * *}}:$ Tv izleme alışkanlıkları ile düşünmeden/fevri hareket etme arasında anlamlı bir fark vardır.

$\mathbf{H}_{21 \mathrm{I}}$

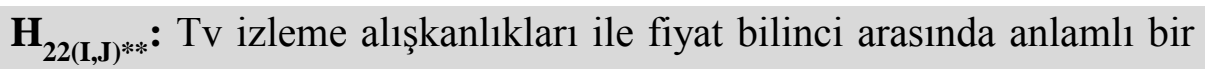
fark vardir.

$\mathbf{H}_{\mathbf{2 3 ( I , J )} \text { **: }}$ Tv izleme alışkanlıkları ile marka bilinci arasında anlamlı bir fark vardır.

$\mathbf{H}_{23 \mathrm{~J}}$

\section{Infomercial reklam içeriği}

$\mathbf{H}_{\text {24(A,B,C,D,E,F,G,H)* }}$ : Demografi ile ödeme şekli ve hayatı kolaylaştırma arasında anlamlı bir fark vardır.

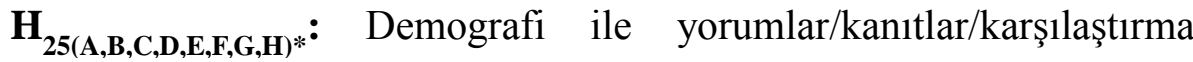
arasında anlamlı bir fark vardır.

$\mathbf{H}_{\text {26(A,B,C,D,E,F,G,H)* }}$ : Demografi ile satın almadan önce ürün hakkındaki düşünce arasında anlamlı bir fark vardır.

$\mathbf{H}_{\text {27(A,B,C,D,E,F,G,H)* }}$ : Demografi ile satın alma öncesinde ki reklam hakkında düşünce arasında anlamlı bir fark vardır. 


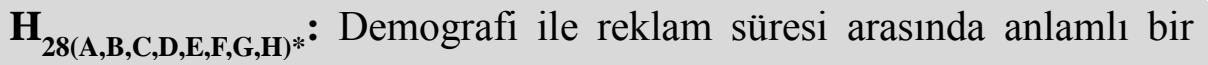
fark vardir.

$\mathbf{H}_{\text {29(I,J)**: }}$ Tv izleme alışkanlıkları ile ödeme şekli ve hayatı $\mathbf{H}_{\mathbf{2 9}}$ kolaylaştırma arasında anlamlı bir fark vardır.

$\mathbf{H}_{\mathbf{3 0}(\mathbf{I}, \mathbf{J})^{* *}}:$ Tv izleme alışkanlıkları ile yorumlar/kanıtlar/karşılaştırma $\quad \mathbf{H}_{\mathbf{3 0 I}}$ arasında anlamlı bir fark vardır.

$\mathbf{H}_{31(\mathbf{I}, \mathbf{J})^{* *}:}:$ Tv izleme alışkanlıkları ile satın alma öncesinde ki ürün hakkında düşünce arasında anlamlı bir fark vardır.

$\mathbf{H}_{32(\mathbf{I},)^{* *}}$ : Tv izleme alışkanlıkları ile satın alma öncesinde ki reklam hakkında düşünce arasında anlamlı bir fark vardır.

$\mathbf{H}_{33(\mathbf{I}, \mathbf{J})^{* * *}}:$ Tv izleme alışkanlıkları ile reklam süresi arasında anlamlı bir fark vardır.

$\mathbf{H}_{6 \mathrm{~B}}, \mathrm{H}_{6 \mathrm{C}}$

$\mathbf{H}_{34}$ : Infomercial reklamlardan satın alanlar ile satın almayanların arasında anlamlı bir fark vardır. 
Araştırmanın modeli şu şekildedir:

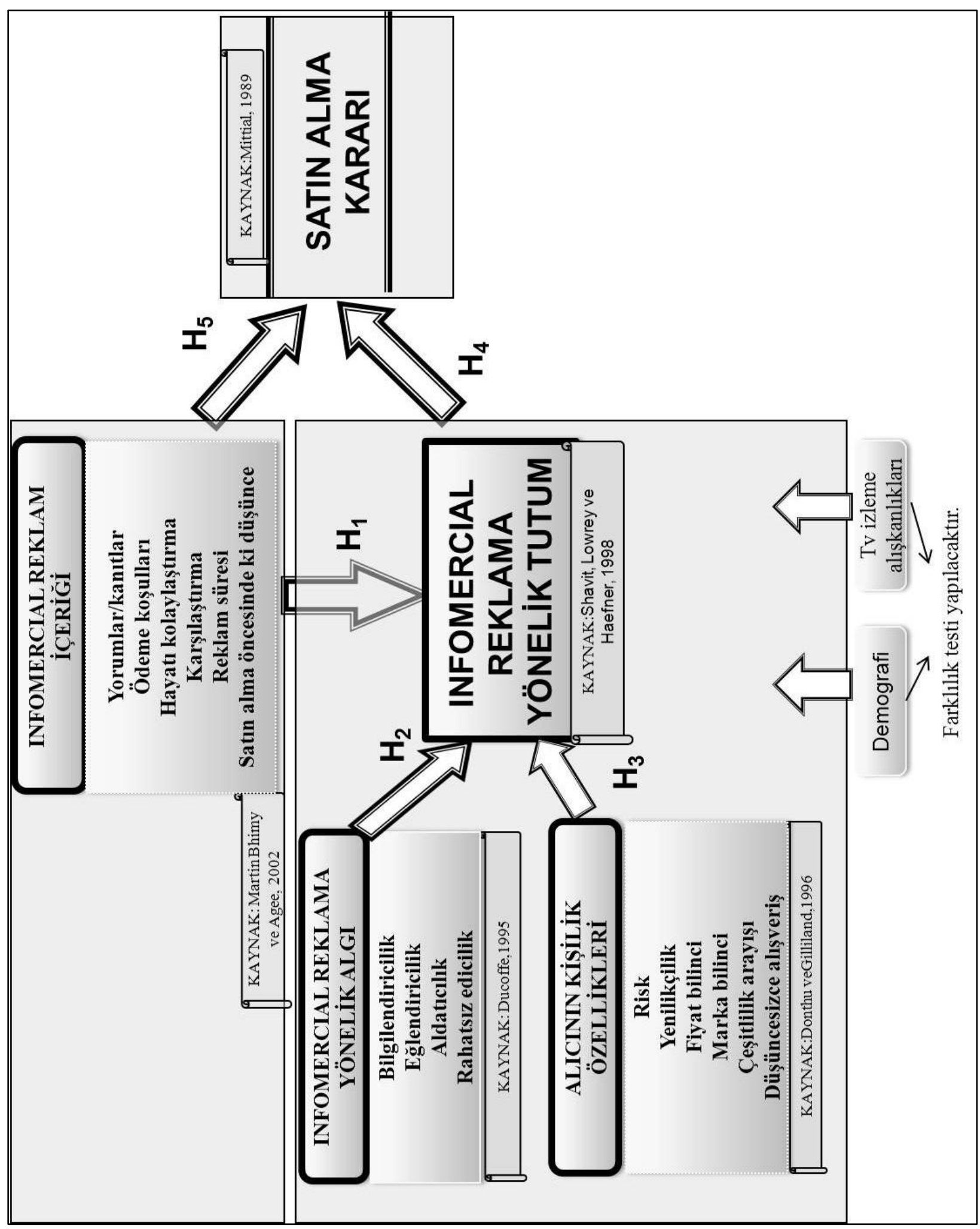

Şekil 9: Anket Modeli

Kaynak: Martin Bhimy ve Agee,2002; Ducoffe1995, Donthu ve Gilliland,1996; Shavit, Lowrey ve Haefner, 1998) 

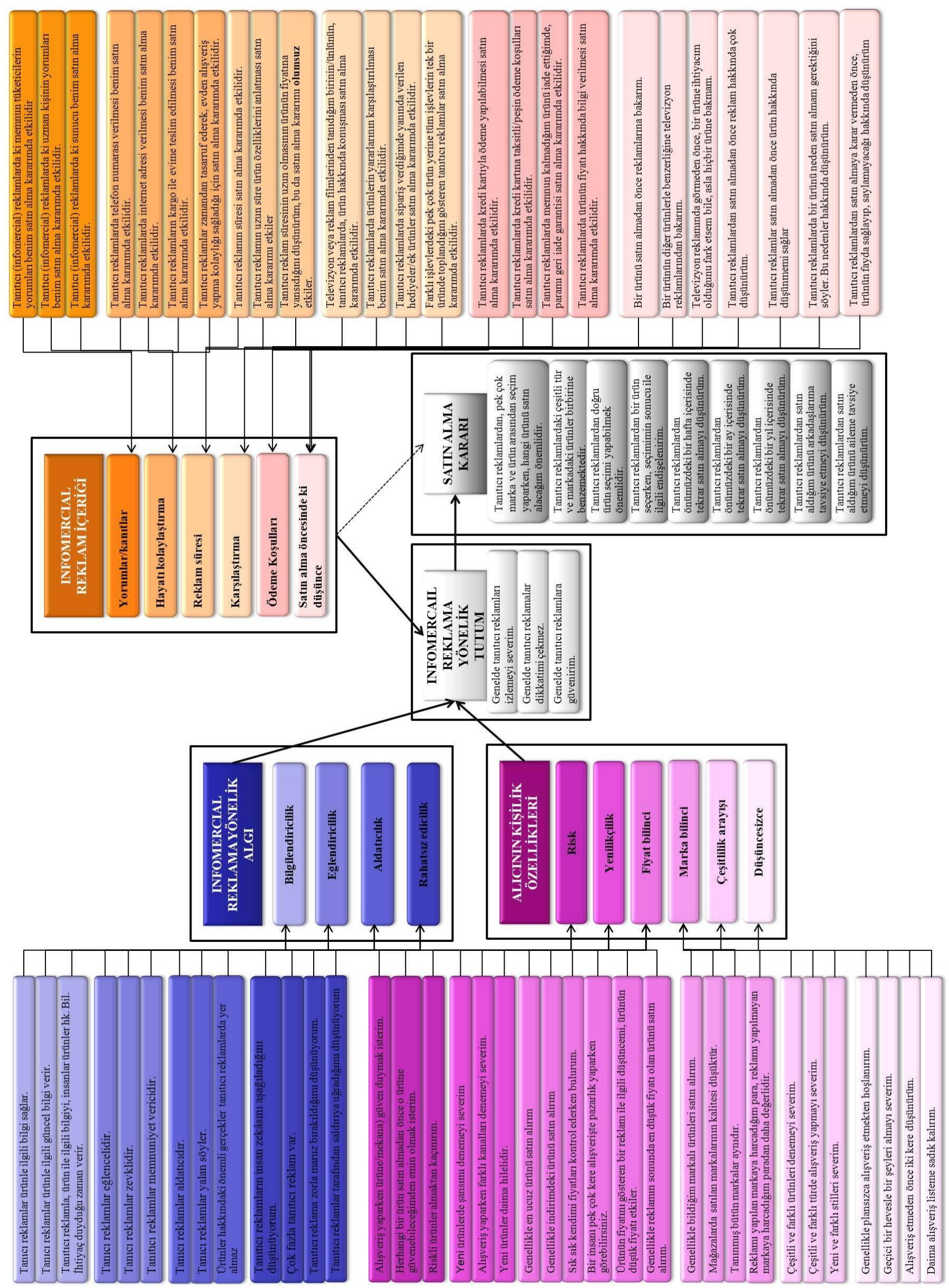
Tablo 4: Infomercial reklam tutumuna yönelik likert ifadeler

\begin{tabular}{|c|c|c|}
\hline Boyutun adi & İfade & Kaynak \\
\hline \multirow{3}{*}{$\begin{array}{l}\text { Infomercial } \\
\text { reklama yönelik } \\
\text { genel tutum }\end{array}$} & $\begin{array}{l}\text { Genelde tanitici(infomercial) reklamları } \\
\text { izlemeyi severim }\end{array}$ & $\begin{array}{l}\text { Shavit, Lowrey ve } \\
\text { Haefner, } 1998\end{array}$ \\
\hline & $\begin{array}{l}\text { Genelde tanıtıcı (infomercial) reklamlar } \\
\text { dikkatimi çekmez }\end{array}$ & $\begin{array}{l}\text { Donthu ve Gilliland, } \\
1996\end{array}$ \\
\hline & $\begin{array}{l}\text { Genelde tanitıcı (infomercial) reklamlara } \\
\text { güvenirim. }\end{array}$ & $\begin{array}{l}\text { Shavit, Lowrey ve } \\
\text { Haefner, } 1998\end{array}$ \\
\hline \multirow{3}{*}{ Bilgilendiricilik } & $\begin{array}{l}\text { Tanıtıcı (infomercial) reklamlar ürünle ilgili } \\
\text { bilgi sağlar. }\end{array}$ & Ducoffe, 1995 \\
\hline & $\begin{array}{l}\text { Tanıtıcı (infomercial) reklamlar ürün ile ilgili } \\
\text { güncel bilgi verir. }\end{array}$ & Ducoffe, 1995 \\
\hline & $\begin{array}{l}\text { Tanıtıcı (infomercial) reklamlar ürünle ilgili } \\
\text { bilgiyi, insanlar ürünler hakkında bilgiye } \\
\text { ihtiyaç duydukları zaman verir. }\end{array}$ & Ducoffe, 1995 \\
\hline \multirow{3}{*}{ Aldatıcılık } & Tanıtıcı (infomercial) reklamlar aldatıcıdır. & Ducoffe, 1995 \\
\hline & Tanıtıcı (infomercial) reklamlar yalan söyler. & Ducoffe, 1995 \\
\hline & $\begin{array}{l}\text { Ürünler hakkındaki önemli gerçekler tanıtıcı } \\
\text { (infomercial) reklamlarda yer almaz }\end{array}$ & Ducoffe, 1995 \\
\hline \multirow{3}{*}{ Ĕglendiricilik } & Tanıtıcı (infomercial) reklamlar eğlencelidir & Ducoffe, 1995 \\
\hline & Tanıtıcı (infomercial) reklamlar zevklidir & Ducoffe, 1995 \\
\hline & $\begin{array}{l}\text { Tanıtıcı (infomercial) reklamlar memnuniyet } \\
\text { vericidir. }\end{array}$ & Ducoffe, 1995 \\
\hline \multirow{5}{*}{ Rahatsız edicilik } & $\begin{array}{l}\text { Tanitıcı (infomercial) reklamlar rahatsız } \\
\text { edicidir }\end{array}$ & Ducoffe, 1995 \\
\hline & $\begin{array}{l}\text { Tanıtıcı (infomercial) reklamların insan } \\
\text { zekâsını aşağıladığını düşünüyorum. }\end{array}$ & Ducoffe, 1995 \\
\hline & Çok fazla tanıtıcı (infomercial) reklam var. & Ducoffe, 1995 \\
\hline & $\begin{array}{l}\text { Infomercial reklama zorla maruz bırakıldığımı } \\
\text { düşünüyorum. }\end{array}$ & $\begin{array}{l}\text { Shavit, Lowrey ve } \\
\text { Haefner, } 1998\end{array}$ \\
\hline & $\begin{array}{l}\text { Infomercial reklamlar tarafından saldırıya } \\
\text { uğradığımı düşünüyorum. }\end{array}$ & $\begin{array}{l}\text { Shavit, Lowrey ve } \\
\text { Haefner, } 1998\end{array}$ \\
\hline
\end{tabular}


Tablo 5: Alıcının kişilik özelliklerine yönelik likert ifadeler

\begin{tabular}{|c|c|c|}
\hline Boyutun adı & Iffade & Kaynak \\
\hline \multirow{4}{*}{ Marka bilinci } & $\begin{array}{l}\text { Genellikle bildiğim markalı ürünleri satın } \\
\text { alırım. }\end{array}$ & $\begin{array}{l}\text { Donthu ve Gilliland, } \\
1996\end{array}$ \\
\hline & $\begin{array}{l}\text { Mağazalarda satılan markalarının kalitesi } \\
\text { düşüktür. }\end{array}$ & $\begin{array}{l}\text { Donthu ve Gilliland, } \\
1996\end{array}$ \\
\hline & Tanınmış bütün markalar aynıdır. & $\begin{array}{l}\text { Donthu ve Gilliland, } \\
1996\end{array}$ \\
\hline & $\begin{array}{l}\text { Reklamı yapılan markaya harcadığım para, } \\
\text { reklamı yapılmayan markaya harcadığım } \\
\text { paradan daha değerlidir. }\end{array}$ & $\begin{array}{l}\text { Shavit, Lowrey ve } \\
\text { Haefner, } 1998\end{array}$ \\
\hline \multirow{6}{*}{ Fiyat bilinci } & Genellikle en ucuz ürünü satın alırım & $\begin{array}{l}\text { Donthu ve Gilliland, } \\
1996\end{array}$ \\
\hline & Genellikle indirimdeki ürünü satın alırım & $\begin{array}{l}\text { Donthu ve Gilliland, } \\
1996\end{array}$ \\
\hline & $\begin{array}{l}\text { Sik sık kendimi fiyatları kontrol ederken } \\
\text { bulurum. }\end{array}$ & $\begin{array}{l}\text { Donthu ve Gilliland, } \\
1996\end{array}$ \\
\hline & $\begin{array}{l}\text { Bir insanı pek çok kere alışverişte pazarlık } \\
\text { yaparken görebilirsiniz. }\end{array}$ & $\begin{array}{l}\text { Donthu ve Gilliland, } \\
1996\end{array}$ \\
\hline & $\begin{array}{l}\text { Ürünün fiyatını gösteren bir reklam ile ilgili } \\
\text { düşüncemi, ürünün düşük fiyatı etkiler. }\end{array}$ & $\begin{array}{l}\text { Shavit, Lowrey ve } \\
\text { Haefner, } 1998\end{array}$ \\
\hline & $\begin{array}{l}\text { Genellikle reklamın sonunda en düşük fiyatı } \\
\text { olan ürünü satın alırım. }\end{array}$ & $\begin{array}{l}\text { Shavit, Lowrey ve } \\
\text { Haefner, } 1998\end{array}$ \\
\hline \multirow{3}{*}{ Çeşitlilik arayışı } & Çeşitli ve farklı ürünleri denemeyi severim. & $\begin{array}{l}\text { Donthu ve Gilliland, } \\
1996\end{array}$ \\
\hline & $\begin{array}{l}\text { Çeşitli ve farklı türde alışveriş yapmayı } \\
\text { severim. }\end{array}$ & $\begin{array}{l}\text { Donthu ve Gilliland, } \\
1996\end{array}$ \\
\hline & Yeni ve farklı stilleri severim. & $\begin{array}{l}\text { Donthu ve Gilliland, } \\
1996\end{array}$ \\
\hline \multirow{4}{*}{$\begin{array}{l}\text { Düşünmeden/ } \\
\text { fevri davranma }\end{array}$} & $\begin{array}{l}\text { Genellikle plansızca alışveriş etmekten } \\
\text { hoşlanırım. }\end{array}$ & $\begin{array}{l}\text { Donthu ve Gilliland, } \\
1996\end{array}$ \\
\hline & Geçici bir hevesle bir şeyleri almayı severim. & $\begin{array}{l}\text { Donthu ve Gilliland, } \\
1996\end{array}$ \\
\hline & Alışveriş etmeden önce iki kere düşünürüm. & $\begin{array}{l}\text { Donthu ve Gilliland, } \\
1996\end{array}$ \\
\hline & Daima alışveriş listeme sadık kalırım. & $\begin{array}{l}\text { Donthu ve Gilliland, } \\
1996\end{array}$ \\
\hline \multirow{3}{*}{ Yenilikçilik } & Yeni ürünlerde şansımı denemeyi severim & $\begin{array}{l}\text { Donthu ve Gilliland, } \\
1996\end{array}$ \\
\hline & $\begin{array}{l}\text { Alışveriş yaparken farklı kanalları denemeyi } \\
\text { severim. (örn. İnternet,tv) }\end{array}$ & $\begin{array}{l}\text { Donthu ve Gilliland, } \\
1996\end{array}$ \\
\hline & Yeni ürünler daima hilelidir. & $\begin{array}{l}\text { Donthu ve Gilliland, } \\
1996\end{array}$ \\
\hline \multirow{3}{*}{ Riskten kaçınma } & $\begin{array}{l}\text { Alışveriş yaparken (ürüne/mekana) güven } \\
\text { duymak isterim. }\end{array}$ & $\begin{array}{l}\text { Donthu ve Gilliland, } \\
1996\end{array}$ \\
\hline & $\begin{array}{l}\text { Herhangi bir ürün satın almadan önce o ürüne } \\
\text { güvenebileceğimden emin olmak isterim. }\end{array}$ & $\begin{array}{l}\text { Donthu ve Gilliland, } \\
1996\end{array}$ \\
\hline & Riskli ürünler almaktan kaçınırım. & $\begin{array}{l}\text { Donthu ve Gilliland, } \\
1996\end{array}$ \\
\hline
\end{tabular}


Tablo 6: Infomercial reklam içeriğine göre yönelik likert ifadeler

\begin{tabular}{|c|c|c|}
\hline Boyutun adı & İfade & Kaynak \\
\hline \multirow{3}{*}{$\begin{array}{c}\text { Yorumlar ve } \\
\text { kanitlar }\end{array}$} & $\begin{array}{l}\text { Tanıtıcı (infomercial) reklamlarda ki memnun } \\
\text { tüketicilerin yorumları benim satın alma } \\
\text { kararımda etkilidir. }\end{array}$ & $\begin{array}{l}\text { Martin, Bhimy ve } \\
\text { Agee, } 2002\end{array}$ \\
\hline & $\begin{array}{l}\text { Tanıtıcı (infomercial) reklamlarda ki uzman } \\
\text { kişinin yorumları benim satın alma kararımda } \\
\text { etkilidir. }\end{array}$ & $\begin{array}{l}\text { Martin, Bhimy ve } \\
\text { Agee,2002 }\end{array}$ \\
\hline & $\begin{array}{l}\text { Tanıtıcı (infomercial) reklamlarda ki sunucu } \\
\text { benim satın alma kararımda etkilidir. }\end{array}$ & $\begin{array}{l}\text { Martin, Bhimy ve } \\
\text { Agee, } 2002\end{array}$ \\
\hline \multirow{4}{*}{ Ödeme koşulları } & $\begin{array}{l}\text { Tanıtıcı (infomercial) reklamlarda kredi } \\
\text { kartıyla ödeme yapılabilmesi satın alma } \\
\text { kararımda etkilidir. }\end{array}$ & $\begin{array}{l}\text { Martin, Bhimy ve } \\
\text { Agee, } 2002\end{array}$ \\
\hline & $\begin{array}{l}\text { Tanıtıcı (infomercial) reklamlarda kredi kartına } \\
\text { taksitli/peşin ödeme koşulları satın alma } \\
\text { kararımda etkilidir. }\end{array}$ & Odak grup \\
\hline & $\begin{array}{l}\text { Tanıtıcı (infomercial) reklamlarda memnun } \\
\text { kalmadığım ürünü iade ettiğimde, paramı geri } \\
\text { iade garantisi satın alma kararımda etkilidir. }\end{array}$ & $\begin{array}{l}\text { Martin, Bhimy ve } \\
\text { Agee, } 2002\end{array}$ \\
\hline & $\begin{array}{l}\text { Tanıtıcı (infomercial) reklamlarda ürünün fiyatı } \\
\text { hakkında bilgi verilmesi satın alma kararımda } \\
\text { etkilidir. }\end{array}$ & $\begin{array}{l}\text { Martin, Bhimy ve } \\
\text { Agee, } 2002\end{array}$ \\
\hline \multirow{4}{*}{$\begin{array}{c}\text { Hayatı } \\
\text { kolaylaştırma }\end{array}$} & $\begin{array}{l}\text { Tanıtıcı (infomercial) reklamlarda telefon } \\
\text { numarası verilmesi benim satın alma kararımda } \\
\text { etkilidir. }\end{array}$ & $\begin{array}{l}\text { Martin, Bhimy ve } \\
\text { Agee, } 2002\end{array}$ \\
\hline & $\begin{array}{l}\text { Tanıtıcı (infomercial) reklamlarda internet } \\
\text { adresi verilmesi benim satın alma kararımda } \\
\text { etkilidir. }\end{array}$ & Odak grup \\
\hline & $\begin{array}{l}\text { Tanıtıcı (infomercial) reklamların kargo ile } \\
\text { evime teslim edilmesi benim satın alma } \\
\text { kararımda etkilidir. }\end{array}$ & Odak grup \\
\hline & $\begin{array}{l}\text { Tanıtıcı (infomercial) reklamlar zamandan } \\
\text { tasarruf ederek, evden alışveriş yapma kolaylığı } \\
\text { sağladığı için satın alma kararımda etkilidir. }\end{array}$ & Donthu ve Gilliland, 1996 \\
\hline \multirow{3}{*}{$\begin{array}{l}\text { Tanıma, } \\
\text { karşılaştırma ve } \\
\text { ekstralar }\end{array}$} & $\begin{array}{l}\text { Televizyon veya reklam filmlerinden tanıdığım } \\
\text { birinin/ünlünün, tanıtıcı (infomercial) } \\
\text { reklamlarda, ürün hakkında konuşması satın } \\
\text { alma kararımda etkilidir. }\end{array}$ & $\begin{array}{l}\text { Martin, Bhimy ve } \\
\text { Agee, } 2002\end{array}$ \\
\hline & $\begin{array}{l}\text { Tanıtıcı (infomercial) reklamlarda ürünlerin } \\
\text { yararlarının karşılaştırılması benim satın alma } \\
\text { kararımda etkilidir. }\end{array}$ & $\begin{array}{l}\text { Martin, Bhimy ve } \\
\text { Agee, } 2002\end{array}$ \\
\hline & $\begin{array}{l}\text { Tanıtıcı (infomercial) reklamlarda sipariş } \\
\text { verdiğimde yanında verilen hediyeler/ek } \\
\text { ürünler (bıçak seti yanında yemek kitabı/bir } \\
\text { alana ikinci üründe hediye gibi) satın alma } \\
\text { kararımda etkilidir. }\end{array}$ & $\begin{array}{l}\text { Martin, Bhimy ve } \\
\text { Agee, } 2002\end{array}$ \\
\hline
\end{tabular}




\begin{tabular}{|c|c|c|}
\hline & $\begin{array}{l}\text { Farklı işlevlerdeki pek çok ürün yerine tüm } \\
\text { işlevlerin tek bir üründe toplandığını gösteren } \\
\text { tanıtıcı (infomercial) reklamlar satın alma } \\
\text { kararımda etkilidir. }\end{array}$ & Odak grup \\
\hline \multirow{3}{*}{ Reklam süresi } & $\begin{array}{l}\text { Tanıtıcı (infomercial) reklamın süresi satın } \\
\text { alma kararımda etkilidir. }\end{array}$ & Odak grup \\
\hline & $\begin{array}{l}\text { Tanıtıcı (infomercial) reklamın uzun süre ürün } \\
\text { özelliklerini anlatması satın alma kararımı } \\
\text { etkiler }\end{array}$ & Odak grup \\
\hline & $\begin{array}{l}\text { Tanıtıcı (infomercial) reklam süresinin uzun } \\
\text { olmasının ürünün fiyatına yansıdığını } \\
\text { düşünürüm, bu da satın alma kararımı olumsuz } \\
\text { etkiler. }\end{array}$ & Odak grup \\
\hline \multirow{7}{*}{$\begin{array}{l}\text { Satın alma } \\
\text { öncesinde ki } \\
\text { düşünce }\end{array}$} & $\begin{array}{l}\text { Bir ürünü satın almadan önce reklamlarına } \\
\text { bakarım. }\end{array}$ & $\begin{array}{l}\text { Martin, Bhimy ve } \\
\text { Agee, } 2002\end{array}$ \\
\hline & $\begin{array}{l}\text { Bir ürünün diğer ürünlerle benzerliğine } \\
\text { televizyon reklamlarından bakarım. }\end{array}$ & $\begin{array}{l}\text { Martin, Bhimy ve } \\
\text { Agee,2002 }\end{array}$ \\
\hline & $\begin{array}{l}\text { Televizyon reklamında görmeden önce, bir } \\
\text { ürüne ihtiyacım olduğunu fark etsem bile, asla } \\
\text { hiçbir ürüne bakmam. }\end{array}$ & $\begin{array}{l}\text { Martin, Bhimy ve } \\
\text { Agee,2002 }\end{array}$ \\
\hline & $\begin{array}{l}\text { Tanıtıcı (infomercial) reklamlardan satın } \\
\text { almadan önce reklam hakkında çok düşünürüm. }\end{array}$ & $\begin{array}{l}\text { Martin, Bhimy ve } \\
\text { Agee,2002 }\end{array}$ \\
\hline & $\begin{array}{l}\text { Tanıtıcı (infomercial) reklamlar satın almadan } \\
\text { önce ürün hakkında düşünmemi sağlar }\end{array}$ & $\begin{array}{l}\text { Martin, Bhimy ve } \\
\text { Agee,2002 }\end{array}$ \\
\hline & $\begin{array}{l}\text { Tanıtıcı (infomercial) reklamlarda bir ürünü } \\
\text { neden satın almam gerektiğini söyler. Bu } \\
\text { nedenler hakkında düşünürüm. }\end{array}$ & $\begin{array}{l}\text { Martin, Bhimy ve } \\
\text { Agee,2002 }\end{array}$ \\
\hline & $\begin{array}{l}\text { Tanıtıcı (infomercial) reklamlardan satın } \\
\text { almaya karar vermeden önce, ürünün fayda } \\
\text { sağlayıp, saylamayacağı hakkında düşünürüm }\end{array}$ & $\begin{array}{l}\text { Martin, Bhimy ve } \\
\text { Agee,2002 }\end{array}$ \\
\hline
\end{tabular}


Tablo 7: Satın alma kararına yönelik likert ifadeler

\begin{tabular}{|c|c|c|}
\hline Boyutun adı & İfade & Kaynak \\
\hline \multirow{9}{*}{$\begin{array}{l}\text { Satın alma } \\
\quad \text { karart }\end{array}$} & $\begin{array}{l}\text { Tanıtıcı (infomercial) reklamlardan, pek } \\
\text { çok marka ve ürün arasından seçim } \\
\text { yaparken, hangi ürünü satın alacağım } \\
\text { önemlidir. }\end{array}$ & Mittial,1989 \\
\hline & $\begin{array}{l}\text { Tanıtıcı (infomercial) reklamlarda ki } \\
\text { çeşitli tür ve markadaki ürünler birbirine } \\
\text { benzemektedir. }\end{array}$ & Mittial,1989 \\
\hline & $\begin{array}{l}\text { Tanıtıcı (infomercial) reklamlardan doğru } \\
\text { ürün seçimi yapabilmek önemlidir. }\end{array}$ & Mittial,1989 \\
\hline & $\begin{array}{l}\text { Tanıtıcı (infomercial) reklamlardan bir } \\
\text { ürün seçerken, seçimimin sonucu ile ilgili } \\
\text { endişeleniyorum }\end{array}$ & Mittial,1989 \\
\hline & $\begin{array}{l}\text { Tanıtıcı (infomercial) reklamlardan } \\
\text { önümüzdeki bir hafta içerisinde tekrar } \\
\text { satın almayı düşünüyorum. }\end{array}$ & \\
\hline & $\begin{array}{l}\text { Tanıtıcı (infomercial) reklamlardan } \\
\text { önümüzdeki bir ay içerisinde tekrar satın } \\
\text { almayı düşünüyorum. }\end{array}$ & \\
\hline & $\begin{array}{l}\text { Tanıtıcı (infomercial) reklamlardan } \\
\text { önümüzdeki bir yıl içerisinde tekrar satın } \\
\text { almayı düşünüyorum. }\end{array}$ & \\
\hline & $\begin{array}{l}\text { Tanıtıcı (infomercial) reklamlardan satın } \\
\text { aldığım ürünü arkadaşlarıma tavsiye } \\
\text { etmeyi düşünüyorum. }\end{array}$ & \\
\hline & $\begin{array}{l}\text { Tanıtıcı (infomercial) reklamlardan satın } \\
\text { aldığım ürünü aileme tavsiye etmeyi } \\
\text { düşünüyorum. }\end{array}$ & \\
\hline
\end{tabular}




\subsection{Araştırma Yöntemi}

Bu bölümde ana kütle ve örnek kütlenin seçimi, veri toplama yöntemi, anket sorularının hazırlanması, veri analizinde kullanılan istatistiki yöntemlere ilişkin bilgiler yer almaktadir.

\subsubsection{Ana Kütle ve Örnek Kütlenin Seçimi}

Bu çalışmada ana kütle olarak, İstanbul'daki tüm televizyon izleyicileri belirlenmiştir. Örnekleme yöntemi olarak ise zaman ve maliyet kısıtlarından dolayı, tesadüfi olmayan örnekleme yöntemlerinden kolayda örnekleme seçilmiştir. Kolayda örneklemenin temel özelliği sadece ulaşılabilir olanların örnek kapsamına dâhil edilmesidir. Tesadüfi olmayan örneklemede, örnekleme hatası istatistiki olarak hesaplanamamaktadır. (GEGEZ, 2005 s. 248-249) Örnek kütle hacmi olarak ise pazarlama araştırmaları için yeterli olacak 400 kişi belirlenmiştir. (GEGEZ, 2005 s. 259)

\subsubsection{Veri Toplama Yönetimi}

Araştırma kalitatif ve kantitatif olmak üzere iki bölümden oluşmaktadır. Araştırmanın kalitatif bölümünde çeşitli meslek gruplarına mensup kişiler ile odak grup görüşmeleri yapılmıştır. 6' şar kişiden oluşan ve toplam dört adet odak grup görüşmesi gerçekleştirilmiştir. Odak grup görüşmelerinin yapılmasının nedeni anketlerin oluşturulmasında yararlı olabilecek bilgiler elde etmek ve tüketicilerin infomercial reklam hakkında ne kadar bilgi sahibi olduklarını belirlemektir.

Odak grup katılımcılarından ilk grup ev hanımları 44,48,54,55,56,56 yaşlarındaki 6 kadın katılımcıdan, ikinci grup emekliler 53,55,56,56,57,58 yaşındaki erkek katılımcılardan, üçüncü grup öğretmenler 26,30,35 yaşlarındaki kadın katılımcılar ile 29,34,35 yaşlarındaki erkek katılımcılarından, dördüncü grup öğrenciler ise 23,24,26 yaşındaki erkek katılımcılar ile 25,26,26 yaşındaki kadınlardan oluşmaktadır. Odak grup görüşmelerinde sorulan sorular ve katılımcıların verdiği yanıtlar şu şekildedir: 


\section{Ev Hanımları}

\begin{tabular}{|c|c|}
\hline $\begin{array}{l}\text { "Tanıtıcı reklam denildiğinde aklınıza } \\
\text { hangi reklamlar gelmektedir." }\end{array}$ & $\begin{array}{l}\text { Programların arasında bir ürünün } \\
\text { tanıtıldığı reklamlar }\end{array}$ \\
\hline $\begin{array}{l}\text { "Tanıtıcı reklamları nasıl } \\
\text { değerlendirirsiniz?" }\end{array}$ & $\begin{array}{l}\text { Bilgilendirici } \\
\text { Eğlenceli }\end{array}$ \\
\hline $\begin{array}{l}\text { "Televizyondan bir numarayı arayarak } \\
\text { alışveriş edebilmek için kişisel } \\
\text { beklentileriniz nelerdir?" }\end{array}$ & Ürünün ucuz olması \\
\hline $\begin{array}{l}\text { "Tanıtıcı reklamlarda ürünü anlatan } \\
\text { kişiler ile ilgili düşünceleriniz nelerdir } \\
\text { ve bu kişilerin satın alma kararınızdaki } \\
\text { etkileri nelerdir?” }\end{array}$ & $\begin{array}{l}\text { Ünlülerin o ürünü gerçekten kullandığına } \\
\text { inanılmaması }\end{array}$ \\
\hline $\begin{array}{l}\text { “Tanıtıcı reklamların ne tür kolaylıklar } \\
\text { sunduğunu düşünürsünüz ve bu } \\
\text { kolaylıklar satın alma kararınızı nasıl } \\
\text { etkiler?” }\end{array}$ & $\begin{array}{l}\text { Ürünün tanınması seçim yapılmasını } \\
\text { kolaylaştırması }\end{array}$ \\
\hline $\begin{array}{l}\text { "Tanıtıcı reklamların ödeme koşulları } \\
\text { ile ilgili ne düşünüyorsunuz?" }\end{array}$ & Ödeme koşullarının zorlayıcı olmadığını \\
\hline
\end{tabular}




\section{Emekliler}

\section{"Tanıtıcı reklam denildiğinde aklınıza Hem uzun süren hem de telefon numarası hangi reklamlar gelmektedir." ve internet adresinin verildiği reklamlar}
"Tanıtıcı reklamları nasıl
Uzun süreli olması nedeniyle sıkıcı

değerlendirirsiniz?"

“Televizyondan bir numarayı arayarak Ürünün işe yaradığından emin olmak alışveriş edebilmek için kişisel

beklentileriniz nelerdir?"

\begin{tabular}{|c|c|}
\hline $\begin{array}{l}\text { "Tanıtıcı reklamlarda ürünü anlatan } \\
\text { kişiler ile ilgili düşünceleriniz nelerdir } \\
\text { ve bu kişilerin satın alma kararınızdaki } \\
\text { etkileri nelerdir?" }\end{array}$ & $\begin{array}{l}\text { Tüketicilerin reklamda rol yaptığına } \\
\text { inanılması }\end{array}$ \\
\hline $\begin{array}{l}\text { "Tanıtıcı reklamların ne tür kolaylıklar } \\
\text { sunduğunu düşünürsünüz ve bu } \\
\text { kolaylıklar satın alma kararınızı nasıl } \\
\text { etkiler?" }\end{array}$ & $\begin{array}{l}\text { Memnun kalınmayan ürünü iade } \\
\text { edebilecek olunması }\end{array}$ \\
\hline $\begin{array}{l}\text { "Tanıtıcı reklamların ödeme koşulları } \\
\text { ile ilgili ne düşünüyorsunuz?" }\end{array}$ & $\begin{array}{l}\text { Reklamın süresinin uzun olmasının } \\
\text { ürünün maliyetine yansıdığını ve bunun } \\
\text { ürün fiyatını arttırdığını }\end{array}$ \\
\hline
\end{tabular}




\section{Öğretmenler}

$\begin{array}{ll}\begin{array}{l}\text { “Tanıtıcı reklam denildiğinde aklınıza } \\ \text { hangi reklamlar gelmektedir." }\end{array} & \begin{array}{l}\text { Uzun süreli, ürünü uzunca tanıtan } \\ \text { reklamlar }\end{array} \\ & \\ \text { "Tanıtıcı reklamları nasıl } & \text { Rahatsız edici } \\ \text { değerlendirirsiniz?" } & \end{array}$
“Televizyondan bir numarayı arayarak Ürünü başka bir yerde (mağazalarda vb.) alışveriş edebilmek için kişisel bulunamaması
beklentileriniz nelerdir?"
“Tanıtıcı reklamlarda ürünü anlatan Tüketicilerin olduğu reklamların kişiler ile ilgili düşünceleriniz nelerdir inandırıcı bulunması
ve bu kişilerin satın alma kararınızdaki
etkileri nelerdir?"
"Tanıtıcı reklamların ne tür kolaylıklar Zamandan tasarruf edilebilmesi sunduğunu düşünürsünüz ve bu
kolaylıklar satın alma kararınızı nasıl
Ürünün kargo ile eve teslim edilmesi etkiler?"
“Tanıtıcı reklamların ödeme koşulları Özellikle sunduğu peşin ya da taksitli ile ilgili ne düşünüyorsunuz?” Ödeme imkânları çok cazip olduğunu




\section{Öğrenciler}

$\begin{array}{ll}\text { "Tanıtıcı reklam denildiğinde aklınıza } & \text { Geleneksel reklamlar içerisindeki bazı } \\ \text { hangi reklamlar gelmektedir." } & \text { reklamlar }\end{array}$

"Tanıtıcı reklamları nasıl

Abart1l1

değerlendirirsiniz?"

"Televizyondan bir numarayı arayarak Ürünün ucuz olması

alışveriş edebilmek için kişisel

beklentileriniz nelerdir?"

"Tanıtıcı reklamlarda ürünü anlatan

kişiler ile ilgili düşünceleriniz nelerdir

ve bu kişilerin satın alma kararınızdaki

etkileri nelerdir?"
Tanıtıcı reklamlardaki kişilerin yabancı olması ve çeviri reklam olması itici.

Yabanc1 karakterler yerine bizden unsurlar olmalı. Türk tüketicisi olmalı. Sunucu Türk olmalı

\section{İnternet adresi verilmesi \\ "Tanıtıcı reklamların ne tür kolaylıklar sunduğunu düşünürsünüz ve bu \\ kolaylıklar satın alma kararınızı nasıl \\ etkiler?"}

"Tanıtıcı reklamların ödeme koşulları ile ilgili ne düşünüyorsunuz?"
Ürünün fiyatı hakkında bilgi verilmesinin çok cazip olduğunu

“Tanıtıcı reklam denildiğinde aklınıza hangi reklamlar gelmektedir” sorusuna, katılımcılardan ev hanımları ve emeklilerin yanıtlarında ayrıntılı bilgilere rastlanırken, telefon numarası verilmesi gibi- öğretmen ve öğrencilerin daha üstünkörü bir değerlendirmede bulundukları gözlemlenmiştir. 
“Tanıtıcı reklamları nasıl değerlendirirsiniz?" sorusuna genel itibariyle ev hanımları tanıtıcı reklamlar ile ilgili olumlu değerlendirmelere sahipken, emekliler, öğretmenler ve öğrencilerin bulunduğu odak gruplar rahatsız olduklarından söz etmektedirler.

“Televizyondan bir numarayı arayarak alışveriş edebilmek için kişisel beklentileriniz nelerdir?" sorusuna, ev hanımları ve öğrenciler televizyondan da ve geleneksel alışverişten de ucuz ürün beklentilerini anlatırken, emekliler ürünün işlevselliğinden beklentilerini dile getirmektedirler. Öğretmenler ise tanıtıcı reklamdaki ürünü başka bir yerde bulamayacaklarını düşünmektedirler.

"Tanıtıcı reklamlarda ürünü anlatan kişiler ile ilgili düşünceleriniz nelerdir ve bu kişilerin satın alma kararınızdaki etkileri nelerdir?" sorusuna tanıtıcı reklamlarda yer alan sunucu, ünlü kişi ya da memnun tüketiciler ile ilgili odak guruplarda olumsuz bir düşünce gözlemlenmektedir. Ürünün satılması için bu kişilere rol yaptırıldığı düşüncesi hâkimdir.

"Tanıtıcı reklamların ne tür kolaylıklar sunduğunu düşünürsünüz ve bu kolaylıklar satın alma kararınızı nasıl etkiler?" sorusuna genel itibariyle tanıtıcı reklamlar kolaylık olarak algılanmaktadır. Reklam içeriğinde yer alan unsurlar, geri iade garantisi, telefon, internet adresi ve kargo ile ürünün teslim edilişi kolaylık unsuru olarak belirtilmektedir.

“Tanıtıcı reklamların ödeme koşulları ile ilgili ne düşünüyorsunuz?” sorusuna genel itibariyle tanıtıcı reklamların ödeme koşullarının kolay ve cazip olduğu yargısı varken, emekliler açısından reklam süresinin maliyetleri arttırdığı için ürün fiyatınında bundan etkilendiği görüşü hâkimdir.

Araştırmanın ikinci bölümünde ise, veri toplama yöntemi olarak anket yöntemi kullanılmıştır. $\mathrm{Bu}$ doğrultuda, soruların anlaşılırlığını test etmek amacı ile anket, öncelikle 20 kişiye uygulanmıştır. Yapılan ön çalışmada katılımcıların sorulara herhangi bir itirazı olmaması sebebiyle ön çalışmaya son verilmiştir.

Araştırmanın ikinci aşamasında veri toplama yöntemi olarak, cevaplamama oranını azaltmak, gözlem yoluyla da bazı bilgiler elde edebilmek, esneklik ve işbirliği sağlayabilmek amacıyla birincil veri toplama yöntemlerinden olan yüz yüze anket yöntemi kullanılmıştır (KURTULUŞ, 1998 s. 269) 
Araştırma 24.01.2011 ve 20.03.2011 tarihleri arasında uygulanmıştır. Anketlerin tamamı eksiksiz doldurulduğu için analizlere 400 anketin tamamı dâhil edilmiştir.

\subsubsection{Anket Sorularının Hazırlanması}

Araştırma için 86 sorudan oluşan bir anket hazırlanmıştır. Ankette infomercial reklama yönelik algı ölçeği 14 soru ile (DUCOFFE, 1995) alıcının kişilik özellikleri ölçeği 23 soru ile (DONTHU, et al., 1996) infomercial reklam içeriği ölçeği 25 soru ile (AGEE, et al., 2002) infomercial reklama yönelik tutum 3 soru ile (SHAVITT, et al., 1998) ve satın alma kararı 9 soru ile (MITTIAL, 1989) ölçülmüştür. Ayrıca demografik özellikler ile ilgili 8 soru sorulurken, televizyon izleme alışkanlıkları ile ilgili 2 soru sorulmuştur. Ölçeklerin orijinalleri İngilizce olup, her biri Türkçe’ye çevrilmiştir. Anketteki tüm likert ifadeler, beşli likert ölçeği ile ölçülmüş ve bu ölçeğe ilişkin kodlama $1=$ Kesinlikle kat1lmiyorum, $2=$ Katılmıyorum, $3=\mathrm{Ne}$ kat1liyorum ne katılmıyorum, 4= Katılıyorum, 5= Kesinlikle katılıyorum şeklinde yapılmıştır.

\subsubsection{Verilerin Analizinde Kullanılan İstatistiki Yöntemler}

İstatistik, veri toplama, düzenleme, özetleme, tablolama, analiz etme ve raporlama bilimidir. Araştırma sırasında toplanan veriler analiz edilerek, araştırma sorularını cevaplayacak bilimsel gerçekler aranır. (SİPAHİ, et al., 2008 s. 3). Araştırma sonucunda elde edilen verilerin analizlerinde SPSS 17.0 programı kullanılmıştır. Analizlere araştırmadan elde edilen verilerin bazılarının frekans dağılımlarına bakılarak başlanmıştır. Daha sonra veri çözümlemeye faktör analizi ile devam edilmiştir. Buradaki amaç, kullandığımız ölçeklerin araştırma sahamızda ne şekilde gruplara ayrıldığını, hangi soruların hangi grup altında inceleneceğini belirlemek ve yapılacak tüm diğer testlerin altyapısını hazırlamaktır. Daha sonra elde ettiğimiz faktörlerin her biri ayrı ayrı güvenilirlik analizine tabi tutulmuştur. Faktör analizi ve güvenilirlik analizinden sonra araştırmada kullanacağımız testlerin seçimi için kritik olan normal dağılım analizleri yapılmıştır. Dağglımın normal dağılıma uygun olduğu görülmüş, bu da bize parametrik testleri kullanma izni vermiştir.

Yapılan odak grup görüşmelerinde farklı demografik özelliklere sahip katılımcıların yöneltilen sorulara farklı yanıtlar vermesi nedeniyle, ikinci grup analiz yöntemlerinde ankette yer alan demografik değişkenlerle ve televizyon izleme 
alışkanlıklarıyla, faktör analizi sonucu ortaya çıkan faktörler arasında ilişki kurmak amacı ile fark testleri yapılmasına karar verilmiştir. Bu amaçla niceliksel verilerin karşılaştırılmasında iki grup durumunda, gruplar arası karşılaştırılmalarında t-testi kullanılmış, ikiden fazla grup durumunda ise ANOVA testi kullanılmıştır.

Araştırma modeli bütünsel olarak ele alınarak Lisrel 8.51 programı ile öncelikle doğrulayıcı faktör analizine, daha sonra yapısal eşitlik modeline başvurulmuştur.

Son olarak araştırma sonuçlarına göre satın alanlar ile satın almayanlar, t-testi yapılarak karşılaştırılmıştır.

\subsection{Araştırma Bulguları ve Bulguların Değerlendirilmesi}

Bu bölümde öncelikle araştırmanın geçerliliği ve güvenilirliği ile ilgili bilgiler verilecek, sonrasında elde edilen bulgular tablolar ve şekiller ile kısaca özetlenecek ve ikinci bölümde bulgular değerlendirilecektir.

\subsection{Araştırma Bulguları}

$\mathrm{Bu}$ bölümde demografik özelliklere yönelik, infomercial reklamdan satın almaya yönelik, faktör ve güvenilirlik analizlerine yönelik, doğrulayıcı faktör analizlerine yönelik, yapısal eşitlik modeline yönelik bulgular ile hipotezler ve hipotezlerin test edilmesine ve ürün satın alanlarla almayanların karşılaştırılmasına yönelik bulguların karşılaştırılmasına yönelik bulgular verilecektir.

\subsubsection{Demografik Özelliklere Yönelik Bulgular}

Araştırmaya katılan 400 cevaplayıcının demografik özelliklerine ait veriler aşağıdaki tablolarda özetlenmiştir. Demografik bilgiler kapsamında cinsiyet, yaş, medeni durum, çocuk sayısı, aylık gelir, haneye giren toplam aylık gelir, eğitim ve meslek gruplarına yönelik bilgilerin dağılımına bakılmaktadır. 
Anketi cevaplayanların 186'sı (\%46) erkek; 214'ü (\%53) kadın olduğu görülmektedir.

Tablo 12:Örneklem Grubunun Cinsiyete Göre Dağılımı

\begin{tabular}{|l|l|l|l|}
\hline & & Frekans & Yüzde \\
\hline \multirow{3}{*}{ CINSIYET } & ERKEK & 186 & $46 \%$ \\
\cline { 2 - 4 } & KADIN & 214 & $53 \%$ \\
\cline { 2 - 4 } & TOPLAM & 400 & $100 \%$ \\
\hline
\end{tabular}

Şekil 11: Örneklem Grubunun Cinsiyete Göre Dağılımı

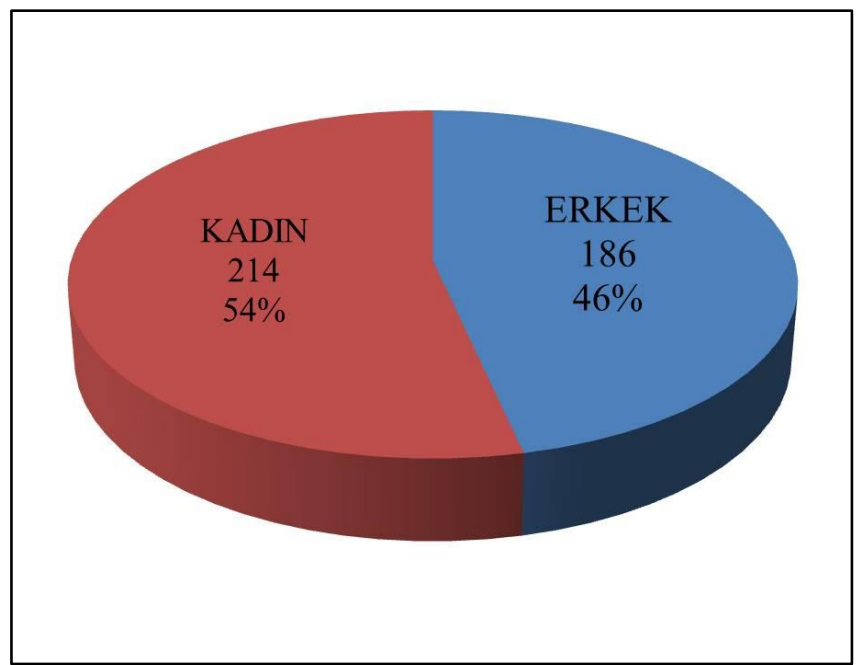


Anketi cevaplayanların 87'si (\%21,8) 16-24 yaş grubunda, 156's1 (\%39) 25-34 yaş gurubunda, 64'ü (\%16) 35-44 yaş grubunda, 57'si $(\% 14,3)$ 45-54 yaş grubunda, 28 (\%7) 55-64 yaş gurubunda ve 8'i (\%2) 65 yaş ve üzeri grubunda olduğu görülmektedir.

Tablo 13:Örneklem Grubunun Yaşa Göre Dağılımı

\begin{tabular}{|l|l|l|l|}
\hline & & Frekans & Yüzde \\
\hline \multirow{5}{*}{ YAŞ } & $16-24$ & 87 & 21,80 \\
\cline { 2 - 4 } & $25-34$ & 156 & 39 \\
\cline { 2 - 4 } & $35-44$ & 64 & 16 \\
\cline { 2 - 4 } & $45-54$ & 57 & 14,3 \\
\cline { 2 - 4 } & $55-64$ & 28 & 7 \\
\cline { 2 - 4 } & 65VE ÜZERİ & 8 & 2 \\
\cline { 2 - 4 } & TOPLAM & 400 & 100 \\
\hline
\end{tabular}

Şekil 12:Örneklem Grubunun Yaşa Göre Dağılımı

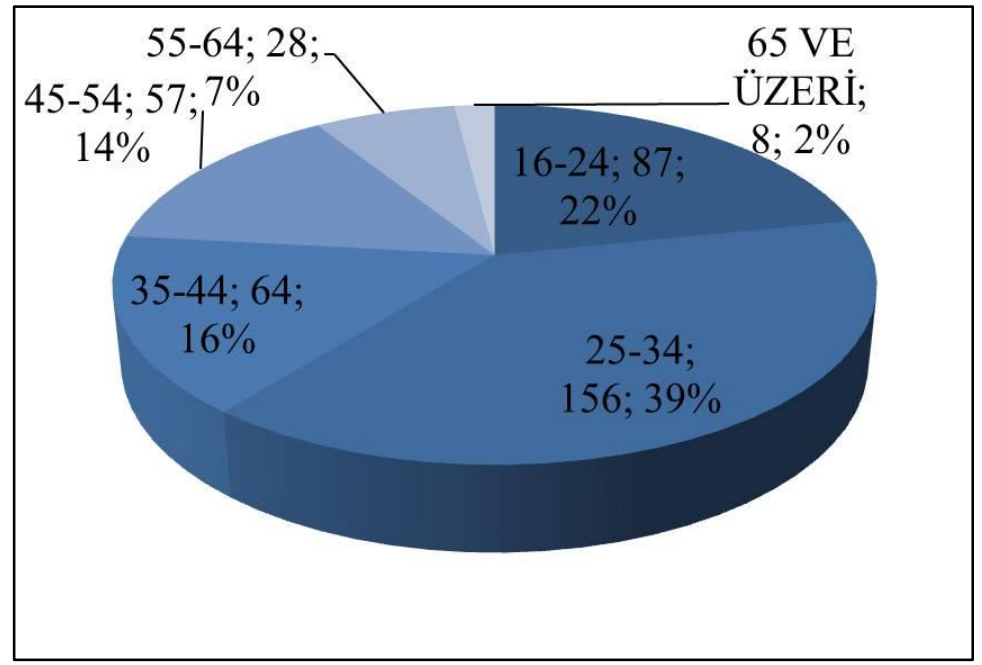


Anketi cevaplayanların 187'si (\%46,8) evli, 189'u (\%47,3) bekar, 13’ü $(\% 3,3)$ boşanmış ve 11 'i $(\% 2,8)$ dul olduğu görülmektedir.

Tablo 14:Örneklem Grubunun Medeni Duruma Göre Dağılımı

\begin{tabular}{|l|l|l|l|}
\hline & & Frekans & Yüzde \\
\hline \multirow{4}{*}{$\begin{array}{c}\text { MEDENI } \\
\text { DURUM }\end{array}$} & EVLİ & 187 & 46,80 \\
\cline { 2 - 4 } & BOŞANMIŞ & 13 & 3,30 \\
\cline { 2 - 4 } & BEKAR & 189 & 47,30 \\
\cline { 2 - 4 } & DUL & 11 & 2,80 \\
\cline { 2 - 4 } & TOPLAM & 400 & 100 \\
\hline
\end{tabular}

Şekil 13: Örneklem Grubunun Medeni Duruma Göre Dağılımı

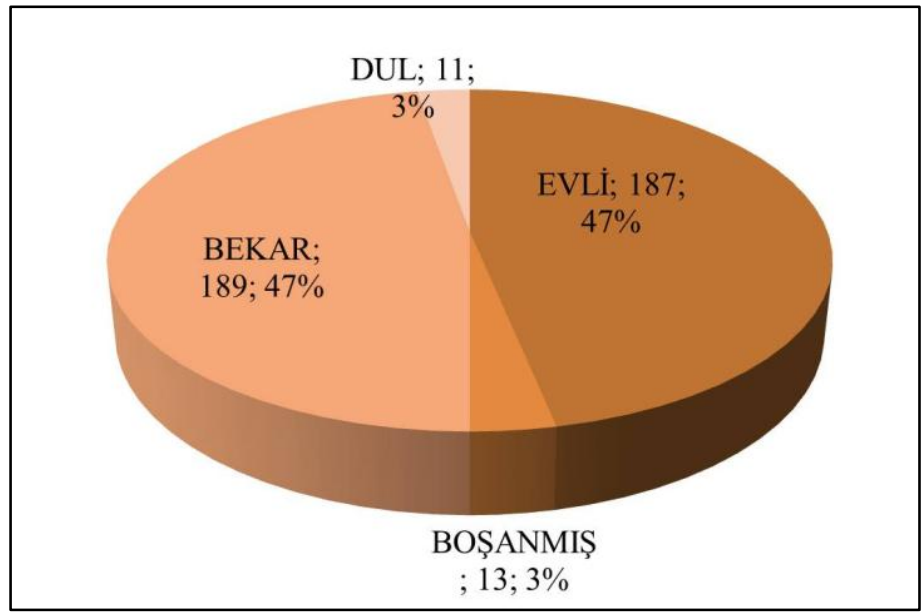


Anketi cevaplayanların 229’u (\%57,3) çocuklarının olmadığını, 52s’i (\%13) 1 tane çocuğunun olduğunu, 69'u $(\% 17,3) 2$ tane çocuğu olduğunu ve 50'si $(\% 12,5) 3$ tane veya daha fazla çocuklarının olduğunu belirtmişlerdir.

Tablo 15: Örneklem Grubunun Sahip Olduğu Çocuk Sayısına Göre Dağılımı

\begin{tabular}{|l|l|l|l|}
\hline & & Frekans & Yüzde \\
\hline \multirow{5}{*}{ ÇOCUK } & YOK & 229 & 57,3 \\
\cline { 2 - 4 } SAYISI & 1 TANE & 52 & 13 \\
\cline { 2 - 4 } & 2 TANE & 69 & 17,3 \\
\cline { 2 - 4 } & $\begin{array}{l}3 \text { TANE VEYA DAHA } \\
\text { FAZLA }\end{array}$ & 50 & 12,5 \\
\cline { 2 - 4 } & TOPLAM & 400 & 100 \\
\hline
\end{tabular}

Şekil 14: Örneklem Grubunun Sahip Olduğu Çocuk Sayısına Göre Dağılımı

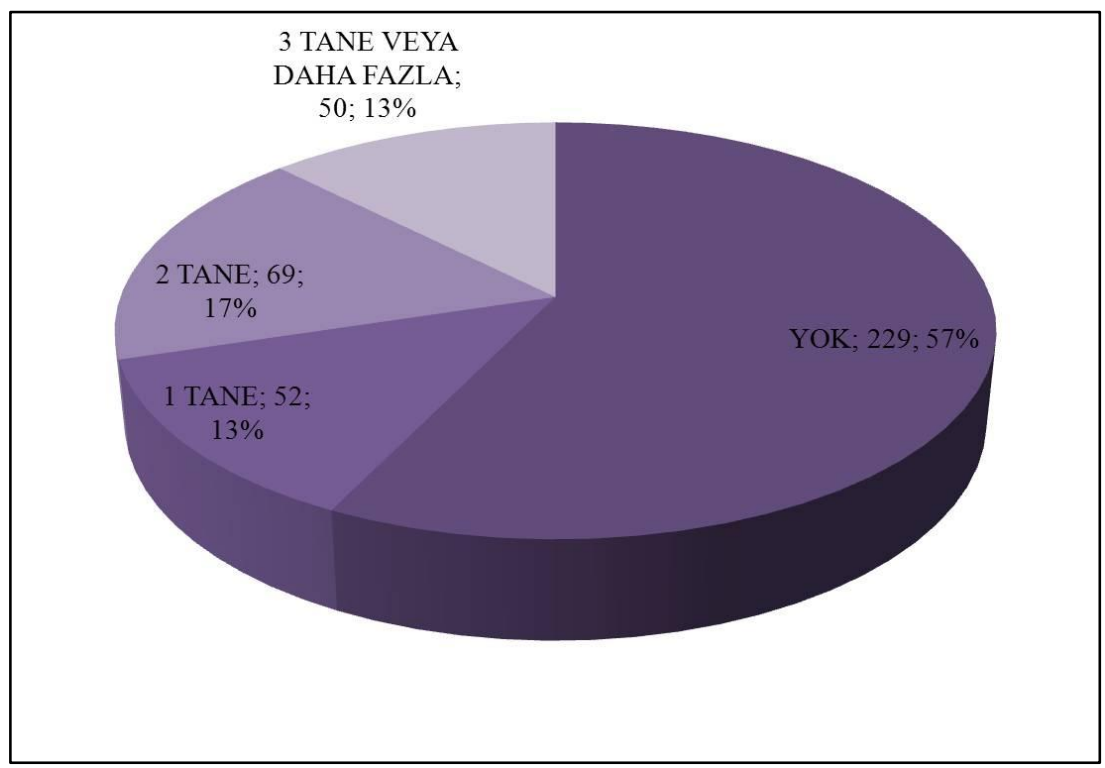


Anketi cevaplayanların 128'i (\%32) 750 TL ve altı gelir düzeyinde,112'si (\%28) 751-1500 TL gelir düzeyinde; 72'si (\%18) 1501-2000 gelir düzeyinde; 27'si (\%6,8) 2001-2500 TL gelir düzeyinde; 20'si (\%5) 2501-3000 TL gelir düzeyinde; 14’ü (\%3,5) 3001-3500 TL, 6’s1 (\%1,5) 3501-4000 TL gelir düzeyinde, 3’ü (\%0,8) 40014500 TL gelir düzeyinde, 7'si (\%1,8) 4501 ve 5000 TL gelir düzeyinde ve 11 'i $(\% 2,8)$ 5001 TL ve üstü gelir düzeyinde olduğu görülmektedir.

Tablo 16: Örneklem Gurubunun Aylık Gelir Düzeyine Göre Dağılımı

\begin{tabular}{|l|l|l|l|}
\hline & & Frekans & Yüzde \\
\hline \multirow{5}{*}{$\begin{array}{l}\text { AYLIK } \\
\text { GELİ }\end{array}$} & 750 TL VE ALTI & 128 & 32 \\
\cline { 2 - 4 } & $751-1500 \mathrm{TL}$ & 112 & 28 \\
\cline { 2 - 4 } & $1501-2000 \mathrm{TL}$ & 72 & 18 \\
\cline { 2 - 4 } & $2001-2500 \mathrm{TL}$ & 27 & 6,8 \\
\cline { 2 - 4 } & $2501-3000 \mathrm{TL}$ & 20 & 5 \\
\cline { 2 - 4 } & $3001-3500 \mathrm{TL}$ & 14 & 3,5 \\
\cline { 2 - 4 } & $3501-4000 \mathrm{TL}$ & 6 & 1,5 \\
\cline { 2 - 4 } & $4001-4500 \mathrm{TL}$ & 3 & 0,8 \\
\cline { 2 - 4 } & $4501-5000 \mathrm{TL}$ & 7 & 1,8 \\
\cline { 2 - 4 } & $5001 \mathrm{TL}$ VE ÜSTÜ & 11 & 2,8 \\
\cline { 2 - 4 } & TOPLAM & 400 & 100 \\
\hline
\end{tabular}

Şekil 15: Örneklem Gurubunun Aylık Gelir Düzeyine Göre Dağılımı

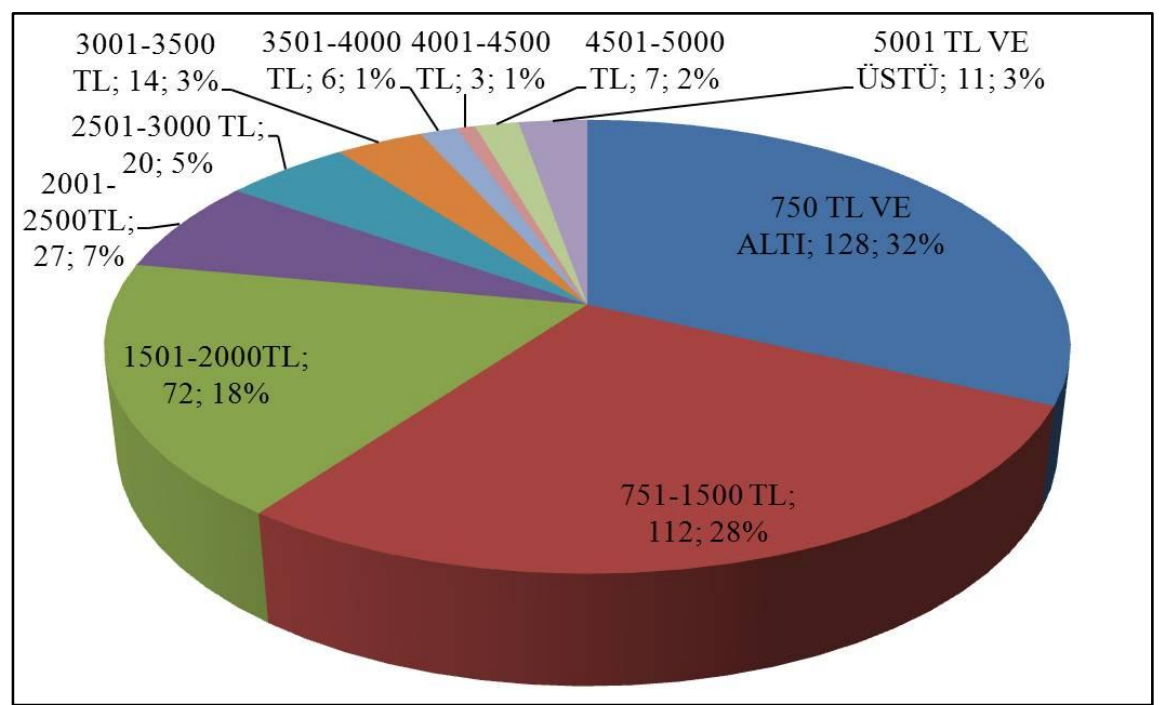


Anketi cevaplayanların 13’ü $(\% 3,3) 750$ TL ve altı gelir düzeyinde, 81'i (\%20,5) 751-1500 TL gelir düzeyinde; 81'i (\%20) 1501-2000 gelir düzeyinde; 57'si (\%14,3) 2001-2500 TL gelir düzeyinde; 35'i $(\% 8,8)$ 2501-3000 TL gelir düzeyinde; 32'si (\%8) 3001-3500 TL, 22'si (\%5,5) 3501-4000 TL gelir düzeyinde, 18'i $(\% 4,5)$ 4001-4500 TL gelir düzeyinde ve 17'si (\%4,3) 4501-5000 TL gelir düzeyinde ve 44'ü (\%11) 5001 TL ve üstü gelir düzeyinde olduğu görülmektedir.

Tablo 17: Örneklem Grubunun Haneye Giren Aylık Gelirine Göre Dağılımı

\begin{tabular}{|l|l|l|l|}
\hline & & Frekans & Yüzde \\
\hline \multirow{5}{*}{$\begin{array}{c}\text { HANEYE } \\
\text { GİREN AYLIK } \\
\text { GELIR }\end{array}$} & 750 TL VE ALTI & 13 & 3,3 \\
\cline { 2 - 4 } & $751-1500 \mathrm{TL}$ & 81 & 20,3 \\
\cline { 2 - 4 } & $1501-2000 \mathrm{TL}$ & 81 & 20,3 \\
\cline { 2 - 4 } & $2001-2500 \mathrm{TL}$ & 57 & 14,3 \\
\cline { 2 - 4 } & $2501-3000 \mathrm{TL}$ & 35 & 8,8 \\
\cline { 2 - 4 } & $3001-3500 \mathrm{TL}$ & 32 & 8 \\
\cline { 2 - 4 } & $3501-4000 \mathrm{TL}$ & 22 & 5,5 \\
\cline { 2 - 4 } & $4001-4500 \mathrm{TL}$ & 18 & 4,5 \\
\cline { 2 - 4 } & $4501-5000 \mathrm{TL}$ & 17 & 4,3 \\
\cline { 2 - 4 } & 5001 TL VE ÜSTÜ & 44 & 11 \\
\cline { 2 - 4 } & TOPLAM & 400 & 100 \\
\hline
\end{tabular}

\section{Şekil 16: Örneklem Grubunun Haneye Giren Aylık Gelirine Göre Dağılımı}

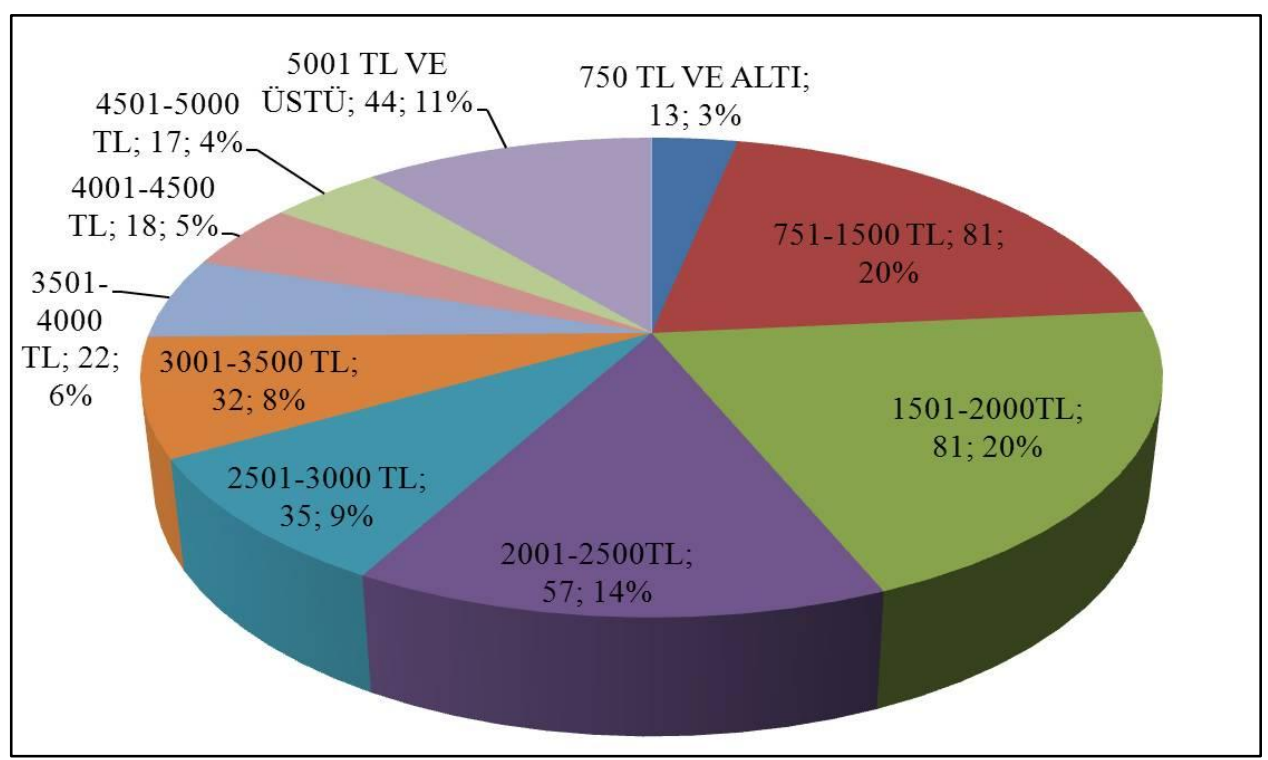


Anketi cevaplayanların 22'si $(\% 5,5)$ ilkokul mezunu; 42'si $(\% 10,5)$ ortaokul mezunu; 114'ü $(\% 28,5)$ lise mezunu; 30’u $(\% 7,5)$ yüksekokul mezunu; 146's1 $(\% 36,5)$ üniversite mezunu; 38'i $(\% 9,5)$ yüksek lisans mezunu ve 8'inin $(\% 2)$ okumadığı ya da doktora yaptığı (diğer) görülmektedir.

Tablo 18: Örneklem Grubunun Eğitim Düzeyine Göre Dağılımı

\begin{tabular}{|l|l|l|l|}
\hline & & Frekans & Yüzde \\
\hline \multirow{4}{*}{$\begin{array}{c}\text { EĞİTİM } \\
\text { DÜZEYİ }\end{array}$} & İLKOKUL & 22 & 5,5 \\
\cline { 2 - 4 } & ORTAOKUL & 42 & 10,5 \\
\cline { 2 - 4 } & LİSE & 114 & 28,5 \\
\cline { 2 - 4 } & YÜKSEKOKUL & 30 & 7,5 \\
\cline { 2 - 4 } & ÜNİVERSİTE & 146 & 36,5 \\
\cline { 2 - 4 } & YÜKSEKLİSANS & 38 & 9,5 \\
\cline { 2 - 4 } & DİĞER & 8 & 2 \\
\cline { 2 - 4 } & TOPLAM & 400 & 100 \\
\hline
\end{tabular}

Şekil 17: Örneklem Grubunun Eğitim Düzeyine Göre Dağılımı

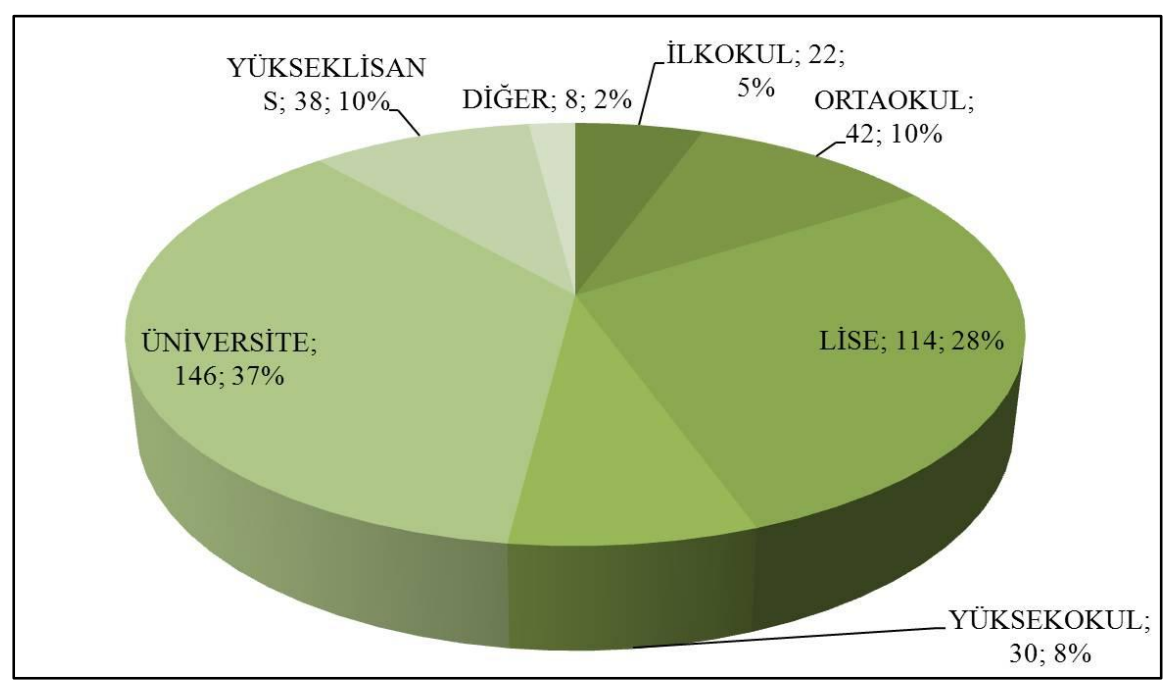


Anketi cevaplayanların 16'sı (\%4) bankacı; 33'ü (\%8) emekli; 58'i (\%14) ev hanımı; 23’ü (\%6) mühendis; 57'si (\%14) öğrenci; 22'si (\%6) öğretmen, 50’si (\%12) özel sektör çalışanı, 51'i (\%13) serbest meslek, 45'i (\%11) kamu sektörü ve 25’i (\%6) diğer meslek gruplarından oldukları görülmektedir.

Tablo 19: Örneklem Grubunun Meslek Grubuna Göre Dağılımı

\begin{tabular}{|l|l|l|c|}
\hline & & Frekans & Yüzde \\
\hline \multirow{5}{*}{ MESLEK } & BANKACI & 16 & 4 \\
\cline { 2 - 4 } & ÖZEL SEKTÖR & 50 & 12 \\
\cline { 2 - 4 } & SERBEST MESLEK & 51 & 13 \\
\cline { 2 - 4 } & KAMU SEKTÖRÜ & 45 & 11 \\
\cline { 2 - 4 } & DİĞER & 25 & 6 \\
\cline { 2 - 4 } & İŞSİZ & 20 & 5 \\
\cline { 2 - 4 } & EMEKLİ & 33 & 8 \\
\cline { 2 - 4 } & EV HANIMI & 58 & 15 \\
\cline { 2 - 4 } & MÜHENDİS & 23 & 6 \\
\cline { 2 - 4 } & $\ddot{O ̈ G ̆ R E N C I ் ~}$ & 57 & 14 \\
\cline { 2 - 4 } & $\ddot{O ̈ G ̆ R E T M E N ~}$ & 22 & 6 \\
\cline { 2 - 4 } & TOPLAM & 400 & 100 \\
\hline
\end{tabular}

Şekil 18: Örneklem Grubunun Meslek Grubuna Göre Dağılımı

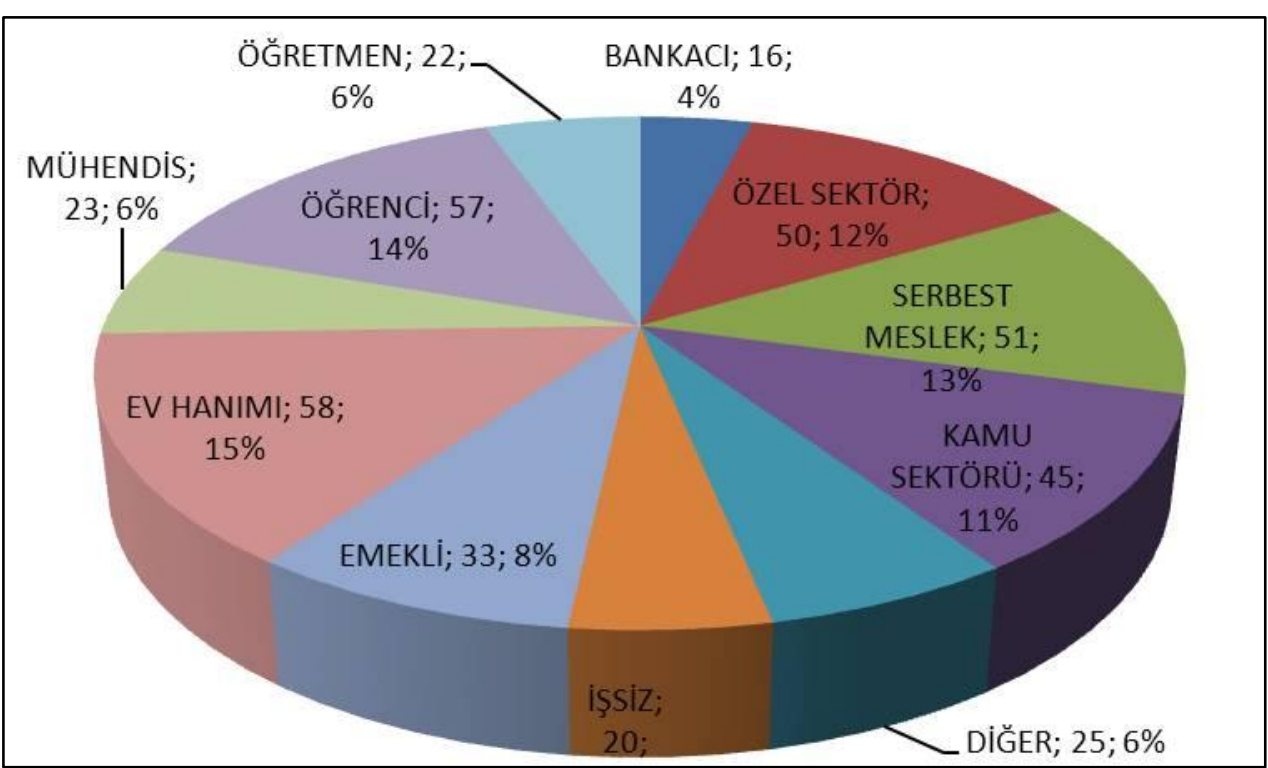




\subsubsection{Infomercial Reklamdan Satın Almaya Yönelik Bulgular}

“Geleneksel kuşak reklamlarından uzun süren, ürünün özelliklerinin ve kullanım şekillerinin bir sunucu veya halktan ürünü deneyen kişi tarafından anlatılan (Kosmodisk Classic omurga masörü, Dr. Levine manyetik dizlik, H2O Buharlı temizleyici gibi) tanıtıcı (infomercial) reklamları izledikten sonra televizyon da verilen numarayı arayarak hiç alışveriş yaptınız mı?” sorusuna anketi cevaplayanların 100'ü (\%25) Evet yanıtını verirken, 300’ü (\%75) Hayır yanıtını verdikleri görülmektedir.

Tablo 20: Örneklem Grubunun Infomercial Reklamlardan Alışveriş Yapmaya Yönelik Dağılımı

\begin{tabular}{|c|c|c|c|}
\hline & & Frekans & Yüzde \\
\hline \multirow{3}{*}{$\begin{array}{c}\text { INFOMERCIAL } \\
\text { REKLAMLARDAN ALIŞVERİŞ } \\
\text { YAPMA }\end{array}$} & EVET & 100 & $25 \%$ \\
\hline & HAYIR & 300 & $75 \%$ \\
\hline & TOPLAM & 400 & $100 \%$ \\
\hline
\end{tabular}

Şekil 19: Örneklem Grubunun Infomercial Reklamlardan Alışveriş Yapmaya Yönelik Dağılım

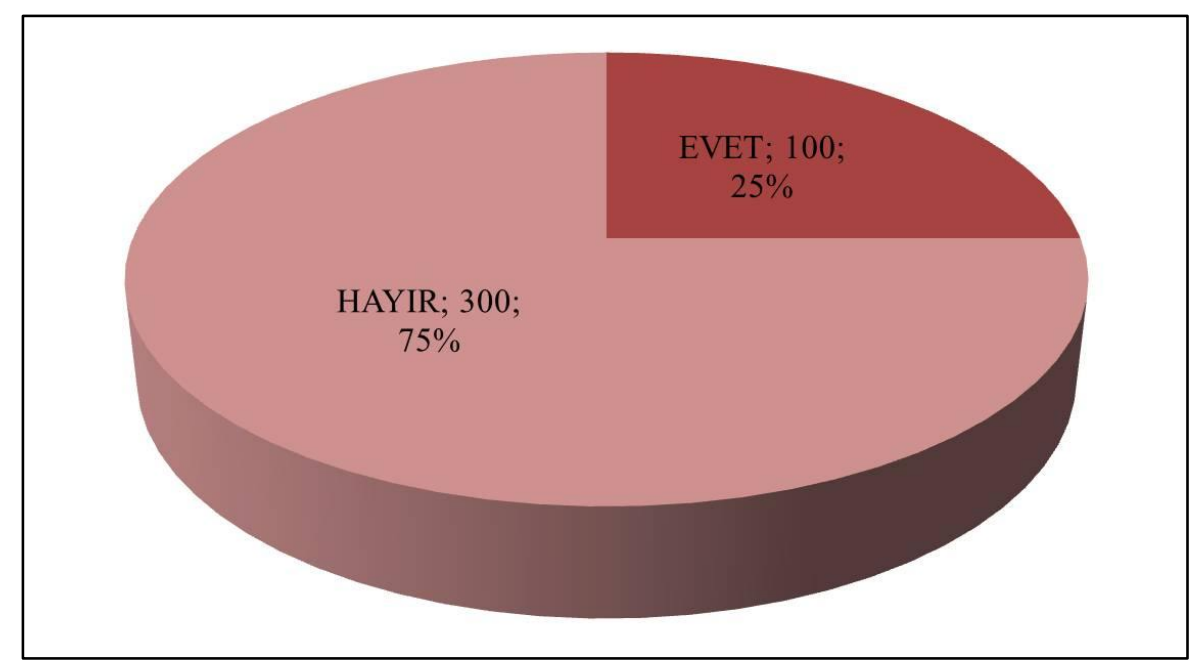


Infomercial reklamlardan alışveriş yapan 100 tüketicinin satın aldığı ürünü belirlemek amacıyla sorulan soruya anketi cevaplayanların 19'u $(\% 4,8)$ egzersiz aletleri, 14 'ü $(\% 3,5)$ mutfak aksesuarları, 9'u (\%2,3) diet programları, 9'u $(\% 2,3)$ eğlence, 16's1 (\%4) sağlık, 9’u (\%2,3) güzellik ve 24'ü (\%6) ev gereçleri satın aldıkları görülmektedir.

Tablo 21: Örneklem Grubunun Infomercial Reklamlardan Satın Aldığı Ürüne Göre Dağılımı

\begin{tabular}{|l|l|l|l|}
\hline & & Frekans & Yüzde \\
\hline \multirow{5}{*}{$\begin{array}{c}\text { ÜRÜN } \\
\text { GRUBU }\end{array}$} & EGZERSİZ ALETLERİ & 19 & 4,8 \\
\cline { 2 - 4 } & $\begin{array}{l}\text { MUTFAK } \\
\text { AKSESUARLARI }\end{array}$ & 14 & 3,5 \\
\cline { 2 - 4 } & DİET PROGRAMLARI & 9 & 2,3 \\
\cline { 2 - 4 } & EĞLENCE & 9 & 2,3 \\
\cline { 2 - 4 } & SAĞLIK & 16 & 4 \\
\cline { 2 - 4 } & GÜZELLİK & 9 & 2,3 \\
\cline { 2 - 4 } & EV GEREÇLERİ & 24 & 6 \\
\cline { 2 - 4 } & TOPLAM & 100 & 100 \\
\hline
\end{tabular}

Şekil 20: Örneklem Grubunun Infomercial Reklamlardan Satın Aldığı Ürüne Göre Dağılımı

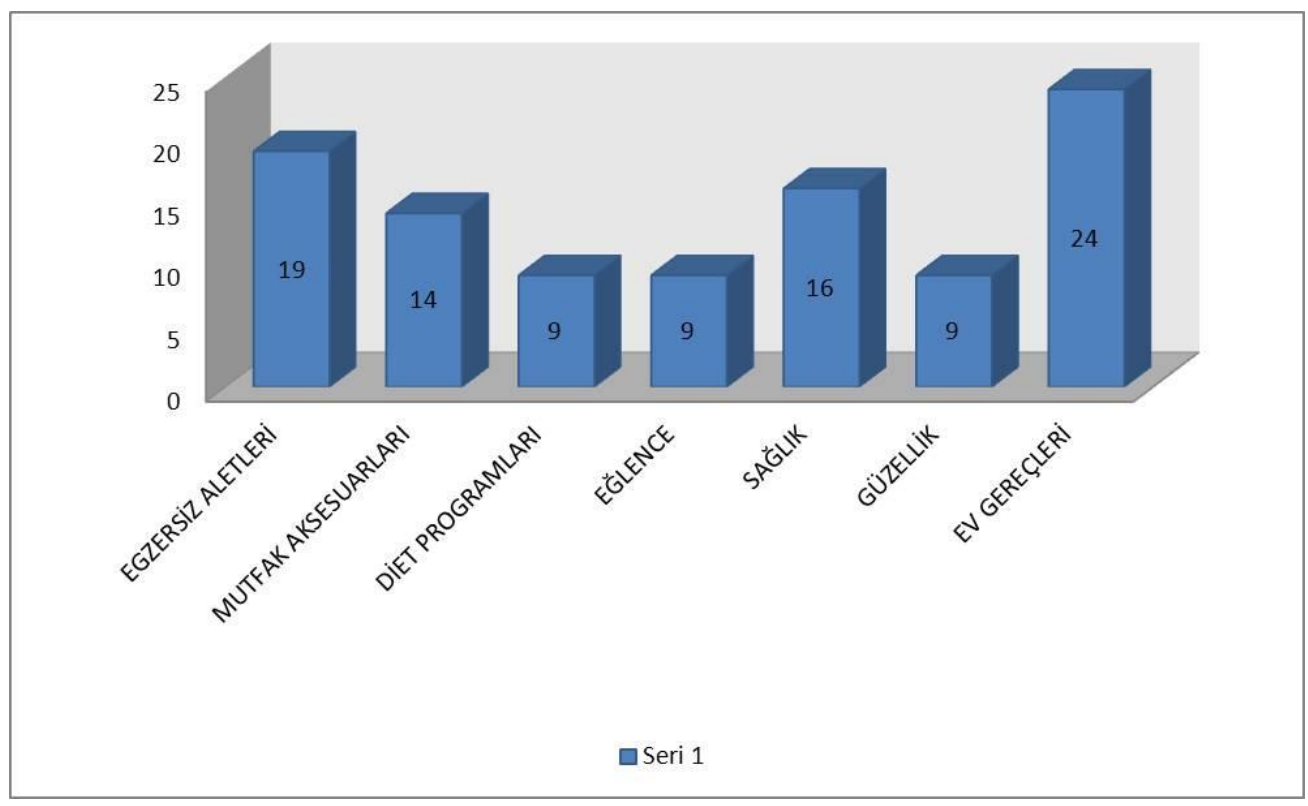


Anketi cevaplayanların haftalık televizyon izlenme oranlarına bakıldığında, 181 'inin $(\% 45,3)$ hafta içi ve hafta sonu genellikle televizyon izledikleri görülmektedir. 116'sı (\%29) hafta içi bazı günler izlediğini belirtirken, 76'sı (\%19) hafta içi her gün ve 27 'sinin $(6,8)$ sadece hafta sonu televizyon izledikleri görülmektedir.

Tablo 22: Örneklem Grubunun Haftalık Televizyon İzleme Oranlarına Göre Dağılımı

\begin{tabular}{|c|c|c|c|}
\hline & & Frekans & Yüzde \\
\hline \multirow{5}{*}{$\begin{array}{l}\text { HAFTALIK TV } \\
\text { IZLLEME }\end{array}$} & SADECE HAFTA SONU & 27 & 6,8 \\
\hline & HAFTAİÇİ HER GÜN & 76 & 19 \\
\hline & HAFTAİÇİ BAZI GÜNLER & 116 & 29 \\
\hline & $\begin{array}{l}\text { HAFTAİÇİ VE HAFTASONU } \\
\text { GENELLİKLE İZLERİM }\end{array}$ & 181 & 45,3 \\
\hline & TOPLAM & 400 & 100 \\
\hline
\end{tabular}

Şekil 21: Örneklem Grubunun Haftalık Televizyon İzleme Oranlarına Göre Dağılımı

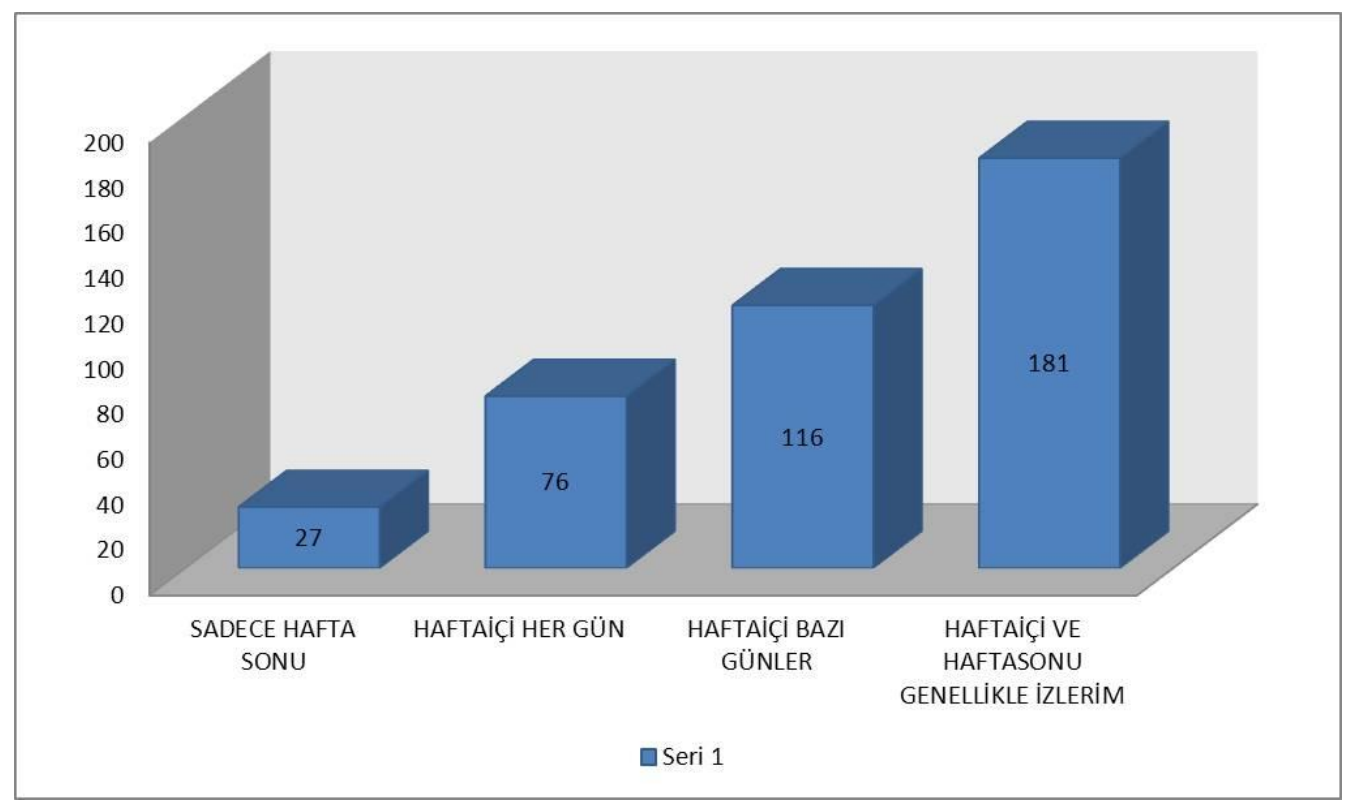


Anketi cevaplayanların gün içerisinde televizyon izleme saatlerine bakıldığında, 25 'nin $(\% 6,3)$ 06.00-10.00 saatleri arasında, 26'sinın (\%6,5) 10.01-12.00 saatleri arasında, 37'sinin (\%9,3) 12.01-19.00 saatleri arasında, 76'sinın (\%19) 19.01-20.00 saatleri arasında ve 236 's (\%59) prime time olarak bilinen 20.01-23.00 saatleri arasında en çok televizyon izledikleri görülmektedir.

Tablo 23: Örneklem Grubunun Saatlik Televizyon İzleme Oranlarına Göre Dağılımı

\begin{tabular}{|c|l|l|l|}
\hline & & Frekans & Yüzde \\
\hline \multirow{4}{*}{$\begin{array}{c}\text { SAATLİK TV } \\
\text { İZLEME }\end{array}$} & $06.00-10.00$ & 25 & 6,3 \\
\cline { 2 - 4 } & $10.01-12.00$ & 26 & 6,5 \\
\cline { 2 - 4 } & $12.01-19.00$ & 37 & 9,3 \\
\cline { 2 - 4 } & $19.01-20.00$ & 76 & 19 \\
\cline { 2 - 4 } & $20.01-23.00$ & 236 & 59 \\
\cline { 2 - 4 } & TOPLAM & 400 & 100 \\
\hline
\end{tabular}

Şekil 22: Örneklem Grubunun Saatlik Televizyon İzleme Oranlarına Göre Dağılım

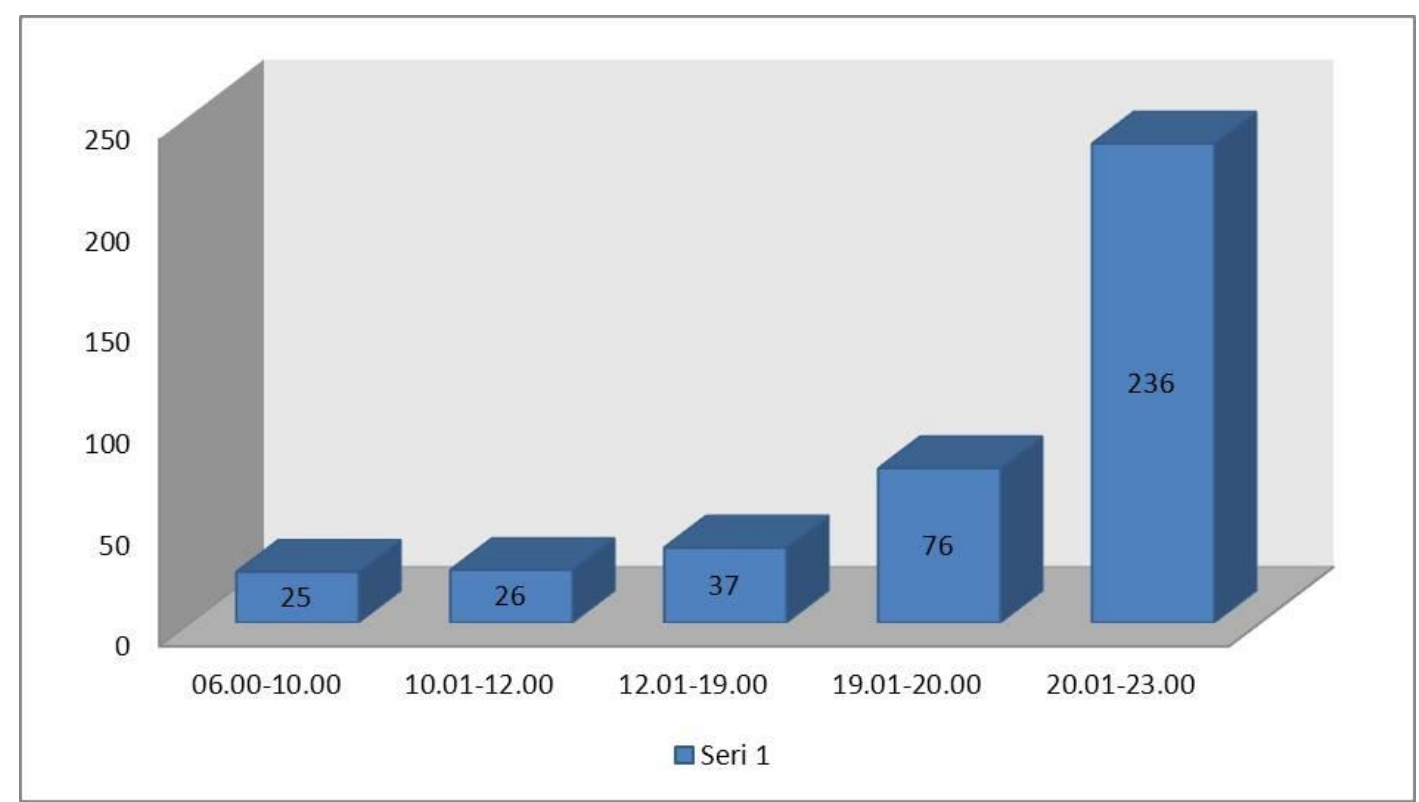




\subsubsection{Faktör Analizleri ve Güvenirlik Analizleri}

Araştırmada kullanılan infomercial reklama yönelik alg1, (Ducoffe,1995), alıcının kişilik özellikleri (Donthu ve Gilliland,1996), infomercial reklam içeriği (Martin, Bhimy ve Agee,2002) ölçeklerinin ortaya çıkan alt boyutlarını tespit etmek amacıyla faktör analizi yapılmıştır. $\mathrm{Bu}$ alt boyutların, ölçeğin geliştirildiği araştırma sahasından farklı çıkma ihtimali ve ölçeklerin yerel şartlara adapte edilmesi için bu gereklidir.

Faktör analizinde öncelikle veri setinin faktör analizine uygunluğunun tespit edilmesi için Kaiser-Meyer-Olkin (KMO) örneklem yeterliliği testi ve Bartlett testi yapılmış, sonuçlar her ölçek için 0,05 önem derecesinde anlamlı olduğundan veri seti faktör analizine uygun bulunmuştur. Sorular temel bileşenler yöntemi ve Varimax döndürme yöntemi kullanılarak analiz edilmiştir.

\subsubsection{Infomercial Reklama Yönelik Algı Ölçeği için Faktör Analizi ve Güvenilirlik Analizi}

Faktör analizi yapılmadan önce örnek kütlenin yeterliliğinin ölçülmesi için Kaiser-Meyer-Olkin (KMO) testi ve Bartlett küresellik testinin (sphericity test) yapılması gerekmektedir. Bu testlerin sonuçları bir kereliğine faktör ve güvenilirlik analizi tablosundan ayrı olarak Tablo 23' de gösterilmektedir.

Tablo 24: KMO ve Bartlett Testi Sonuçları

\begin{tabular}{|l|l|l|}
\hline \multicolumn{2}{|l|}{ Kaiser-Meyer-Olkin Measure of Sampling } & 0,800 \\
\hline Bartleet's Test of & Approx. Chi-Square & 2577,701 \\
Sphericity & df & 91 \\
& Sig & 0,000 \\
\hline
\end{tabular}

KMO değerine baktığımızda değişkenlerin faktör analizine uygunluğunun mükemmel seviyede olduğu görülmektir. Ayrıca Bartlett testinin geçerli olması da, analiz sonuçlarının anlamlı olduğunu göstermektedir. Bu analizlere göre faktör analizi uygulanabilmektedir. Infomercial reklama yönelik alg1 modelinde yer alan 14 değişkenin kaç faktör altında toplandığının belirlenebilmesi için keşifsel faktör analizi uygulanmıştır. Varimax rotasyonu kullanılarak yapılan temel bileşenler faktör analizinin (principal components factor analysis) sonuçlarına göre değişkenler 4 boyut altında toplanmaktadır. Faktör analizi sonuçları Tablo 24’ de gösterilmektedir. 
Tablo 25: Infomercial Reklama Yönelik Algı Ölçeği için Faktör Analizi

\begin{tabular}{|c|c|c|c|c|}
\hline Faktörün Adı & \multicolumn{2}{|l|}{ Soru İfadesi } & Güvenilirlik & $\begin{array}{l}\text { Faktörün } \\
\text { Açıklayıclı̆̆g }\end{array}$ \\
\hline \multirow{3}{*}{ EĞLENDIRICİLIK } & $\begin{array}{l}\text { Tanitıcı (infomercial) reklamlar } \\
\text { eğlencelidir. }\end{array}$ & 0,914 & \multirow{3}{*}{0,891} & \multirow{3}{*}{18,566} \\
\hline & Tanıtıcı (infomercial) reklamlar zevklidir. & 0,864 & & \\
\hline & $\begin{array}{l}\text { Taniticı (infomercial) reklamlar } \\
\text { memnuniyet vericidir. }\end{array}$ & 0,800 & & \\
\hline \multirow{5}{*}{ RAHATSIZ EDİCİLIK } & $\begin{array}{l}\text { Tanitici (infomercial) reklamlar rahatsız } \\
\text { edicidir. }\end{array}$ & 0,850 & \multirow{5}{*}{0,797} & \multirow{5}{*}{37,010} \\
\hline & $\begin{array}{l}\text { Tanıtıcı (infomercial) reklamların insan } \\
\text { zekâsını aşağıladığını düșünüyorum. }\end{array}$ & 0,821 & & \\
\hline & Çok fazla tanıtıcı (infomercial) reklam var. & 0,694 & & \\
\hline & $\begin{array}{l}\text { Tanıtıcı (infomercial) reklama zorla maruz } \\
\text { bırakıldığımı düşünüyorum. }\end{array}$ & 0,517 & & \\
\hline & $\begin{array}{l}\text { Tanıtıcı (infomercial) reklamlar tarafindan } \\
\text { saldırıya uğradığımı düşünüyorum. }\end{array}$ & 0,468 & & \\
\hline \multirow{3}{*}{ ALDATICILIK } & Tanitıc1 (infomercial) reklamlar aldatıcıdır. & 0,835 & \multirow{3}{*}{0,800} & \multirow{3}{*}{54,318} \\
\hline & $\begin{array}{l}\text { Tanitıc1 (infomercial) reklamlar yalan } \\
\text { söyler. }\end{array}$ & 0,821 & & \\
\hline & $\begin{array}{l}\text { Ürünler hakkındaki önemli gerçekler } \\
\text { tanıtıcı (infomercial) reklamlarda yer } \\
\text { almaz. }\end{array}$ & 0,730 & & \\
\hline \multirow{3}{*}{ BİLGÍLENDİRICIILIKK } & $\begin{array}{l}\text { Tanitıcı (infomercial) reklamlar ürünle ilgili } \\
\text { bilgi sağlar. }\end{array}$ & 0,854 & \multirow{3}{*}{0,684} & \multirow{3}{*}{67,505} \\
\hline & $\begin{array}{l}\text { Tanitıcı (infomercial) reklamlar ürün ile } \\
\text { ilgili güncel bilgi verir. }\end{array}$ & 0,831 & & \\
\hline & $\begin{array}{l}\text { Tanıtıcı (infomercial) reklamlar ürünle ilgili } \\
\text { bilgiyi, insanlar ürünler hakkında bilgiye } \\
\text { ihtiyaç duydukları zaman verir. }\end{array}$ & 0,480 & & \\
\hline & \multicolumn{2}{|c|}{ Kaiser-Meyer-Olkin Measure of Sampling } & \multicolumn{2}{|l|}{0,800} \\
\hline \multicolumn{2}{|c|}{$\begin{array}{r}\text { Bartleet's Test of } \\
\text { Sphericity }\end{array}$} & $\begin{array}{r}\text { Approx. Chi-Square } \\
\text { df } \\
\text { Sig }\end{array}$ & \multicolumn{2}{|l|}{$\begin{array}{l}2577,701 \\
91 \\
0,000\end{array}$} \\
\hline
\end{tabular}

İlgili literatür incelendiğinde faktörlerde yer alan bileşenlerin alacağı faktör yüklerine dair farklı bilgilerin olduğu görülmektedir. Özdamar (2003) faktörleri oluşturan bileşenlerin 0,3 ' ün üzerinde faktör yükü aldığında faktöre dahil edileceğini belirtirken Durmuş, Yurtkoru, Çinko (2008) 0,5'in altında kalan bileşenlerin faktöre dahil edilmemesini ifade etmektedir. Bu çalışmada "Tanıtıcı (infomercial) reklamlar tarafından saldırıya uğradığımı düşünüyorum” değişkeni 0,468, "Tanıtıcı (infomercial) reklamlar ürünle ilgili bilgiyi, insanlar ürünler hakkında bilgiye ihtiyaç duydukları zaman verir" değişkeni ise 0,480 faktör yükü almıştır. Görüldüğü gibi bu bileşenlerin faktör yükü 0,5 'in altındadır. Bu bileşenlerin faktöre dâhil edilip edilmemesi konusunda tereddüt edilmiş olup, güvenilirlik analizlerinde bu sorunun güvenilirliğe yaptığı yüksek etkiden dolayı faktör içinde kalması uygun görülmüştür. 
Faktör analizinde bulunan dört faktörün isimleri altlarında toplanan değişkenlerin ağırlıkları, çalışmanın teorik esaslarından yola çıkılarak verilmişstir.

Faktörlerin oluşmasında öz değeri 1'den büyük olan dört faktör bulunmaktadır. Bu dört faktör toplam varyansın \% 67,505'ini açıklamaktadır.

Faktör analizini gerçekleştirdikten ve dört adet faktörü elde ettikten sonra, araştırmanın bulgularının değerlendirilmesi aşamasında yapacağımız analiz yorumlarının daha geçerli bir sonuç elde etmek amacıyla güvenilirlik analizi yapılmıştır. Analiz yapılırken Alpha modelinden yararlanılmış ve 0,60'ın üzerinde çıkan değerler kabul edilmiştir. Faktörlerin güvenilirliğinin 0,891(>0,60), 0,797(>0,60), $0,800(>0,60)$ ve $0,684(>0,60)$ şeklinde değerler alması faktörler için yüksek bir güvenilirliğin olduğunu göstermektedir.

\subsubsection{Alıcının Kişilik Özellikleri Ölçeği için Faktör Analizi ve Güvenilirlik Analizi}

Alıcının kişilik özellikleri ölçeği için yapılan faktör analizi sonucunda ilk olarak 7 boyut oluşmuştur. Faktörü bozan herhangi bir değere rastlanmadığı için güvenilirlik analizlerine geçilmiştir. Güvenilirlik analizleri sonucunda "marka bilinci" olarak isimlendirilen 4.faktörün güvenilirlik değerini yükselteceği için s37 değerlendirme dışında bırakılarak ikinci kez faktör analizi yenilenmiştir. Aynı faktör için s27'de değerlendirme dışında bırakılarak üçüncü kez faktör analizi yapılmıştır. "Düşünmeden/fevri hareket etme" faktörü olarak isimlendirilen 4.faktörün güvenilirlik değerinin düşük çıktığı görülmüş ve buna sebep olan, negatif faktör yüküne sahip olan, s43 ve s44 ters kodlanarak analize bundan böyle bu şekilde devam edilmiştir. S34, s31 ve s32'den oluşan 6.faktörün güvenilirliği 0,60'1n altında kalması nedeniyle değerlendirmeden çıkarılarak dördüncü defa faktör analizi yenilenmiştir. Bunun sonucunda 6 boyut kalmış olup, güvenilirlikler kontrol edildiğinde s25 ve s26'dan oluşan “yenilikçilik” olarak isimlendirilen faktörün güvenilirliğinin de 0,60'ın altında kaldığı görülmüştür. Analizden çıkarılan bu boyut ile birlikte beşinci kez faktör analizi yapılmış ve sonuç itibariyle öz değeri 1 ve üzerinde olan 5 boyut oluşmuştur. Alıcının kişilik özellikleri ölçeği için yapılan son KMO analizi ve son faktör analizleri sonuçları Tablo 25'de verilmektedir. 
Tablo 26: Alıcının Kişilik Özellikleri Ölçeği için Faktör Analizi

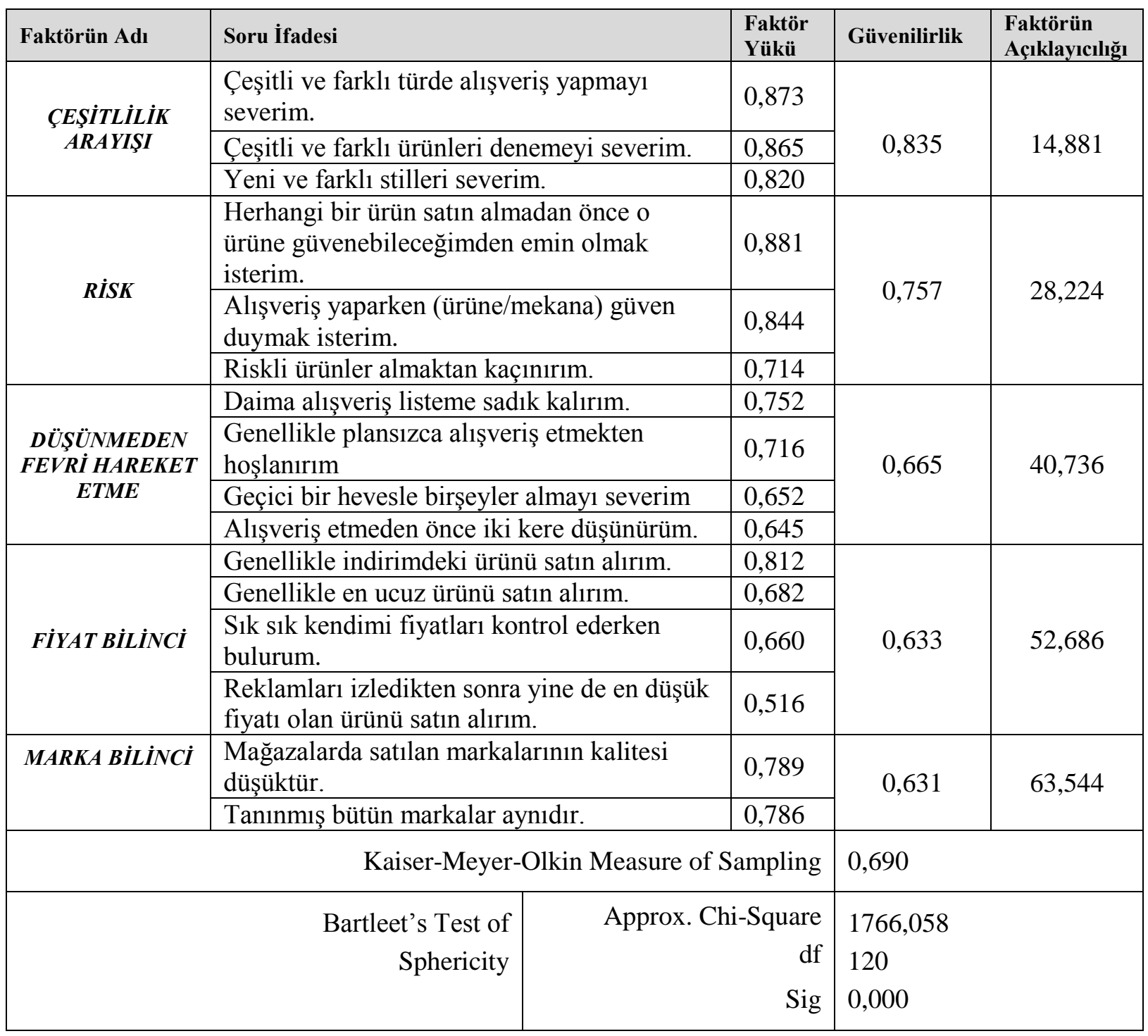

KMO değerinin 0,690 çıkması faktör analizine uygunluğunu ve Bartleet testinin sonucunun geçerli olması da, analiz sonuçlarının anlamlı olduğunu göstermektedir. Bu analizlere göre faktör analizi uygulanabilmektedir.

Varimax rotasyonu kullanılarak yapılan faktör analizinde, faktörlerin oluşmasında öz değeri 1 ve büyük olan beş faktör bulunmaktadır. Bu beş faktör toplam varyansın \% 63,544'ünü açıklamaktadır.

Faktörlerin içsel tutarlılıklarının hesaplanmasında Cronbach Alpha değerleri kullanılmıştır. Faktörlerin güvenilirliğinin 0,835(>0,60), 0,757(>0,60), 0,665 (>0,60), $0,633(>0,60)$ ve $0,631(>0,60)$ şeklinde değerler alması faktörler için yüksek bir güvenilirliğin olduğunu göstermektedir. 


\subsubsection{Infomercial Reklam İçeriği Ölçeği için Faktör Analizi ve Güvenilirlik Analizi}

Tablo 27: Infomercial Reklam İçeriği Ölçeği için Faktör Analizi

\begin{tabular}{|c|c|c|c|c|}
\hline Faktörün Adı & Soru İfadesi & $\begin{array}{c}\text { Faktör } \\
\text { Yükü }\end{array}$ & Güvenilirlik & $\begin{array}{c}\text { Faktörün } \\
\text { Açıklayıclı̆ı̆ı }\end{array}$ \\
\hline \multirow{8}{*}{$\begin{array}{c}\text { ÖDEME ŞEKLI } \\
\text { VE HAYATI } \\
\text { KOLAYLASTIIRM } \\
\text { A }\end{array}$} & $\begin{array}{l}\text { Tanıtıcı (infomercial) reklamlarda kredi kartına } \\
\text { taksitli/peşin ödeme koşulları satın alma } \\
\text { kararımda etkilidir. }\end{array}$ & 0,809 & \multirow{8}{*}{0,933} & \multirow{8}{*}{21,683} \\
\hline & $\begin{array}{l}\text { Tanıtıcı (infomercial) reklamlarda ürünün } \\
\text { fiyatı hakkında bilgi verilmesi satın alma } \\
\text { kararımda etkilidir. }\end{array}$ & 0,785 & & \\
\hline & $\begin{array}{l}\text { Tanıtıcı (infomercial) reklamlarda memnun } \\
\text { kalmadığım ürünü iade ettiğimde, paramı geri } \\
\text { iade garantisi satın alma kararımda etkilidir. }\end{array}$ & 0,765 & & \\
\hline & $\begin{array}{l}\text { Tanıtıcı (infomercial) reklamlarda kredi } \\
\text { kartıyla ödeme yapılabilmesi satın alma } \\
\text { kararımda etkilidir. }\end{array}$ & 0,748 & & \\
\hline & $\begin{array}{l}\text { Tanitıci (infomercial) reklamlarda internet } \\
\text { adresi verilmesi benim satın alma kararımda } \\
\text { etkilidir. }\end{array}$ & 0,705 & & \\
\hline & $\begin{array}{l}\text { Tanıtıcı (infomercial) reklamlar zamandan } \\
\text { tasarruf ederek, evden alışveriş yapma } \\
\text { kolaylığı sağladığı için satın alma kararımda } \\
\text { etkilidir. }\end{array}$ & 0,688 & & \\
\hline & $\begin{array}{l}\text { Tanıtıcı (infomercial) reklamlardaki ürünlerin } \\
\text { kargo ile evime teslim edilmesi benim satın } \\
\text { alma kararımda etkilidir. }\end{array}$ & 0,688 & & \\
\hline & $\begin{array}{l}\text { Tanıtıcı (infomercial) reklamlarda telefon } \\
\text { numarası verilmesi benim satın alma } \\
\text { kararımda etkilidir. }\end{array}$ & 0,648 & & \\
\hline \multirow{6}{*}{$\begin{array}{c}\text { YORUMLAR, } \\
\text { KANITLAR VE } \\
\text { KARSSILAŞTIRMA }\end{array}$} & $\begin{array}{l}\text { Tanıtıcı (infomercial) reklamlarda ki sunucu } \\
\text { benim satın alma kararımda etkilidir. }\end{array}$ & 0,829 & \multirow{6}{*}{0,903} & \multirow{6}{*}{38,806} \\
\hline & $\begin{array}{l}\text { Tanıtıcı (infomercial) reklamlarda ki memnun } \\
\text { tüketicilerin yorumları benim satın alma } \\
\text { kararımda etkilidir. }\end{array}$ & 0,805 & & \\
\hline & $\begin{array}{l}\text { Tanıtıcı (infomercial) reklamlarda ki uzman } \\
\text { kissinin yorumları benim satın alma kararımda } \\
\text { etkilidir. }\end{array}$ & 0,763 & & \\
\hline & $\begin{array}{l}\text { Televizyon veya reklam filmlerinden tanıdığım } \\
\text { bir ünlünün, tanıtıcı (infomercial) reklamlarda, } \\
\text { ürün hakkında konuşması satın alma kararımda } \\
\text { etkilidir. }\end{array}$ & 0,763 & & \\
\hline & $\begin{array}{l}\text { Tanıtıcı (infomercial) reklamlarda ürünlerin } \\
\text { yararlarının karşılaştırılması benim satın alma } \\
\text { kararımda etkilidir. }\end{array}$ & 0,678 & & \\
\hline & $\begin{array}{l}\text { Tanıtıcı (infomercial) reklamlarda sipariş } \\
\text { verdiğimde yanında verilen hediyeler/ek } \\
\text { ürünler (bıçak seti yanında yemek kitabı/bir } \\
\text { alana ikinci üründe hediye gibi) satın alma } \\
\text { kararımda etkilidir. }\end{array}$ & 0,548 & & \\
\hline
\end{tabular}




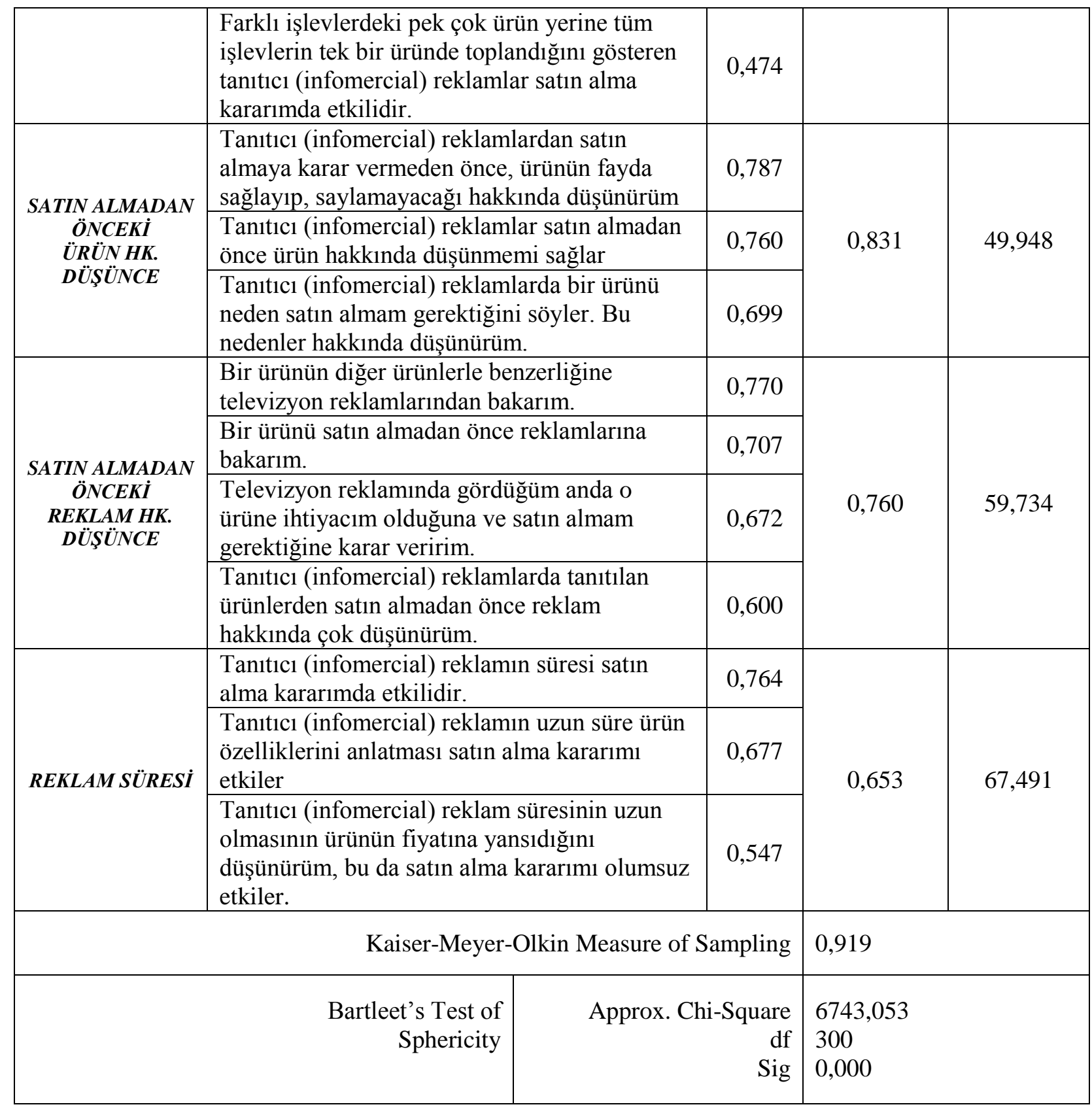

KMO değerinin 0,919 çıkması faktör analizine uygunluğunu ve Bartleet testinin sonucunun geçerli olması da, analiz sonuçlarının anlamlı olduğunu göstermektedir. Bu analizlere göre faktör analizi uygulanabilmektedir.

Varimax rotasyonu kullanılarak yapılan faktör analizinde, faktörlerin oluşmasında öz değeri 1 ve büyük olan beş faktör bulunmaktadır. Bu beş faktör toplam varyansın \% 67,491'ini açıklamaktadır.

Faktörlerin içsel tutarlılıklarının hesaplanmasında kullanılan Cronbach Alpha değerleri $0,933(>0,60), 0,903(>0,60), 0,831(>0,60), 0,760(>0,60)$ ve $0,653(>0,60)$ 
şeklinde değerler almıştır. Bu değerler faktörler için yüksek bir güvenilirliğin olduğunu göstermektedir.

\subsubsection{Tutum Kavramının Faktör ve Güvenilirlik Analizi}

Bağımlı değişkenimiz olan tutum kavramı KMO ve Bartleet testinin sonucunda faktör analizine tabii tutulabileceği görülmektedir.

Tablo 28: KMO ve Bartlett Testi Sonuçları

\begin{tabular}{|l|l|l|}
\hline \multicolumn{2}{|l|}{ Kaiser-Meyer-Olkin Measure of Sampling } & 0,582 \\
\hline $\begin{array}{l}\text { Bartleet's Test } \\
\text { of }\end{array}$ & Approx. Chi-Square & 207,384 \\
Sphericity & df & 3 \\
& Sig & 0,000 \\
\hline
\end{tabular}

Varimax rotasyonu kullanılarak yapılan faktör analizinde Component Matrix'in tek bir boyuttan oluştuğu için hesaplanamadığı görülmektedir. "Genelde tanıtıcı reklamları izlemeyi severim"(s5), "Genelde tanıtıcı reklamlar dikkatimi çekmez.”(s6) ve “ Genelde tanıtıcı reklamlara güvenirim.”(s7) İfadelerinden oluşan faktör, güvenilirlik analizine tabi tutulduğunda ilk olarak ters ifade sonucu güvenilirliği düşük çıkmış daha sonra s5 ters kodlanarak güvenilirlik analizi tekrarlanmıştır. Analiz sonucunda $0,631(<0,6)$ değeri elde edilmiştir. Elde edilen bu sonuçla bir faktör oluştuğuna karar verilir. Bu tek faktör toplam varyansın \%59,585'ini açıklamaktadır.

\subsubsection{Satın Alma Kavramının Faktör ve Güvenilirlik Analizi}

Diğer bağımlı değişkenimiz olan satın alma kavramının KMO ve Bartleet testinin sonucunda faktör analizine tabii tutulabileceği görülmektedir. 
Tablo 29: Satın Alma Kavramının Faktör Analizi

\begin{tabular}{|c|c|c|c|c|}
\hline $\begin{array}{l}\text { Faktörün } \\
\text { Adı }\end{array}$ & Soru İfadesi & $\begin{array}{l}\text { Faktör } \\
\text { Yükü }\end{array}$ & Güvenilirlik & $\begin{array}{l}\text { Faktörün } \\
\text { Açıklayıcılığı }\end{array}$ \\
\hline \multirow{5}{*}{$\begin{array}{c}\text { GELECEKT } \\
\text { EKI SATIN } \\
\text { ALMA } \\
\text { NIYETI }\end{array}$} & $\begin{array}{l}\text { Tanıtıcı (infomercial) reklamlardan } \\
\text { önümüzdeki bir ay içerisinde tekrar satın } \\
\text { almayı düşünüyorum. }\end{array}$ & 0,880 & \multirow{5}{*}{0,916} & \multirow{5}{*}{42,279} \\
\hline & $\begin{array}{l}\text { Tanıtıcı (infomercial) reklamlardan satın } \\
\text { aldığım ürünü aileme tavsiye etmeyi } \\
\text { düşünüyorum. }\end{array}$ & 0,868 & & \\
\hline & $\begin{array}{l}\text { Tanıtıcı (infomercial) reklamlardan satın } \\
\text { aldığım ürünü arkadaşlarıma tavsiye etmeyi } \\
\text { düşünüyorum. }\end{array}$ & 0,859 & & \\
\hline & $\begin{array}{l}\text { Tanıtıc1 (infomercial) reklamlardan } \\
\text { önümüzdeki bir yıl içerisinde tekrar satın } \\
\text { almayı düşünüyorum. }\end{array}$ & 0,857 & & \\
\hline & $\begin{array}{l}\text { Tanitıcı (infomercial) reklamlardan } \\
\text { önümüzdeki bir hafta içerisinde tekrar satın } \\
\text { almayı düşünüyorum. }\end{array}$ & 0,831 & & \\
\hline \multirow{4}{*}{$\begin{array}{l}\text { SATIN } \\
\text { ALMA } \\
\text { NIYETI }\end{array}$} & $\begin{array}{l}\text { Tanıtıcı (infomercial) reklamlardan doğru ürün } \\
\text { seçimi yapabilmek önemlidir. }\end{array}$ & 0,769 & \multirow{4}{*}{0,740} & \multirow{4}{*}{67,487} \\
\hline & $\begin{array}{l}\text { Tanıtıcı (infomercial) reklamlarda gösterilen } \\
\text { pek çok marka ve ürün arasından seçim } \\
\text { yaparken, hangi ürünü satın alacağım } \\
\text { önemlidir. }\end{array}$ & 0,768 & & \\
\hline & $\begin{array}{l}\text { Tanıtıcı (infomercial) reklamlardan bir ürün } \\
\text { seçerken, seçimimin sonucunda beni tatmin } \\
\text { edip etmeyeceği ile ilgili endişeleniyorum. }\end{array}$ & 0,761 & & \\
\hline & $\begin{array}{l}\text { Tanıtıcı (infomercial) reklamlarda ki çeşitli tür } \\
\text { ve markadaki ürünler birbirine benzemektedir. }\end{array}$ & 0,662 & & \\
\hline \multicolumn{3}{|c|}{ Kaiser-Meyer-Olkin Measure of Sampling } & \multicolumn{2}{|l|}{0,781} \\
\hline \multicolumn{2}{|r|}{$\begin{array}{r}\text { Bartleet's Test of } \\
\text { Sphericity }\end{array}$} & $\begin{array}{r}\text { i-Square } \\
\text { df } \\
\text { Sig }\end{array}$ & \multicolumn{2}{|l|}{$\begin{array}{l}2348,997 \\
36 \\
0,000\end{array}$} \\
\hline
\end{tabular}

Diğer bağımlı değişkenimiz olan satın alma kavramının KMO ve Bartleet testinin sonucunda faktör analizine tabii tutulabileceği görülmektedir.

Varimax rotasyonu kullanılarak yapılan faktör analizinde, faktörlerin oluşmasında öz değeri 1 ve büyük olan iki faktör bulunmaktadır. Bu iki faktör toplam varyansın \% 67,487'sini açıklamaktadır.

Faktörlerin içsel tutarlılıklarının hesaplanmasında kullanılan Cronbach Alpha değerleri $0,916(>0,60)$ ve 0,740 $(>0,60)$ şeklinde değerler almıştır. Bu değerler faktörler için yüksek bir güvenilirliğin olduğunu göstermektedir. 


\subsection{4. Ölçekler İçin Doğrulayıcı Faktör Analizleri}

Doğrulayıcı Faktör Analizi, araştırmalarda yaygın ve klasik olarak kullanılan Açıklayıcı (keşfedici) Faktör Analizi ile belirlenmiş olan faktör yapılarının doğrulanmasını test etmek amacıyla uygulanan bir yöntemdir. Doğrulayıcı Faktör Analizi, ölçek geliştirme çalışmalarında veya bir kültürde geliştirilmiş bir ölçeğin başka bir kültüre uyarlamasını yaparken kullanılabilecek bir geçerlilik kanıtı bulma yöntemidir. (ŞİMŞEK, 2007 s. 4-5)

Açıklayıcı Faktör Analizi yapıldığında araştırmacı; ortak faktörlerin sayısı, değişkenlere göre ilgili gizil faktörlerin sayısı, regresyon katsayıları, modelinin ya da faktörlerinin ilişkili ya da dikey olup olmadığı hakkında önceden bir bilgiye sahip değildir. Açıklayıcı Faktör Analizi genellikle, bir tanımlayıcı ve açıklayıcı süreç iken, Doğrulayıcı Faktör Analizinde bir model önceden yapılandırılmamıştır ve modelin değerlendirilmesi ve tanımlanması için güçlü bir deneysel ve kavramsal bir alt yapıya ihtiyaç duymaktadır. Açıklayıcı Faktör Analizi faktörlerin sayısını belirlerken, Doğrulayıcı Faktör Analizi önsel olarak faktörlerin sayısını sabit olarak almaktadır. (YILMAZ, et al., 2009 s. 53)

Ölçeklerin uyum indeksleri için Lisrel 8.51 programı kullanılmıştır. Modeldeki gözlemlenen değişkenlerin faktörler üzerindeki etkisi Şekil 22, Şekil 23, Şekil 24 ve Şekil 25'de ve bu etkinin modelin alt parçalarında ne düzeyde uyumlu olduğu Tablo 30'da gösterilmiştir. 
Doğrulayıcı faktör analizinde (latent variable) örtük değişken olarak adlandırılan değişkenler, faktör analizinde elde edilen boyutlardır.

Modelde örtük değişkenler için kullanılan kısaltmalar şunlardır:

\begin{tabular}{|c|c|}
\hline Kisaltma & Açıklama \\
\hline eglen & Eğlendiricilik \\
\hline rahatsiz & Rahatsız Edicilik \\
\hline aldat & Aldatıcilık \\
\hline bilgilen & Bilgilendiricilik \\
\hline cesitli & Çeşitlilik \\
\hline risk & Risk \\
\hline dusuncesiz & Düşünmeden/Fevri Hareket Etme \\
\hline fiyatbil & Fiyat Bilinci \\
\hline markabil & Marka Bilinci \\
\hline odeme & Ödeme Şekli ve Hayatı Kolaylaştırıcılık \\
\hline yorum & Yorumlar, Kanıtlar ve Karşılaştırma \\
\hline dusunce & Satın Almadan Önceki Ürün hk. Düşünce \\
\hline dusunce 2 & $\begin{array}{l}\text { Satın Almadan Önceki Reklam hk. } \\
\text { Düşünce }\end{array}$ \\
\hline sure & Reklam Süresi \\
\hline tutum & Tutum \\
\hline karar & Satın Alma Kararı \\
\hline
\end{tabular}

Tablo 30: Modelde Kullanılan Örtük Değişkenler

İkili nominal ölçek (evet-hayır) ile ölçülen satın alma kararı yeterli varyans değerine ulaşamadığından dolayı "nedensellik teknikleri” açısından kullanılamamaktadır. Onun yerine gelecekteki olası satın alma kararı modele eklenmiştir. (BAYRAKTAR, 2004)

Modeldeki ana değişkenler olan infomercial reklama yönelik alg1, alıcının kişilik özellikleri ve infomercial reklam içeriği değişkenlerinin yapıları Şekil 23/24, Şekil 24/25 ve Şekil 25/26'de gösterilmiştir. 


\section{Şekil 23: Reklama Yönelik Algı Lisrel Çıktısı}

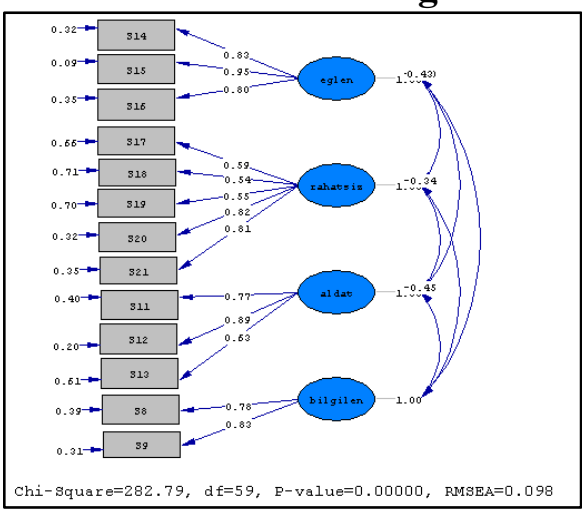

\section{Şekil 24: Infomercial Reklama Yönelik Algı Ölçeği}

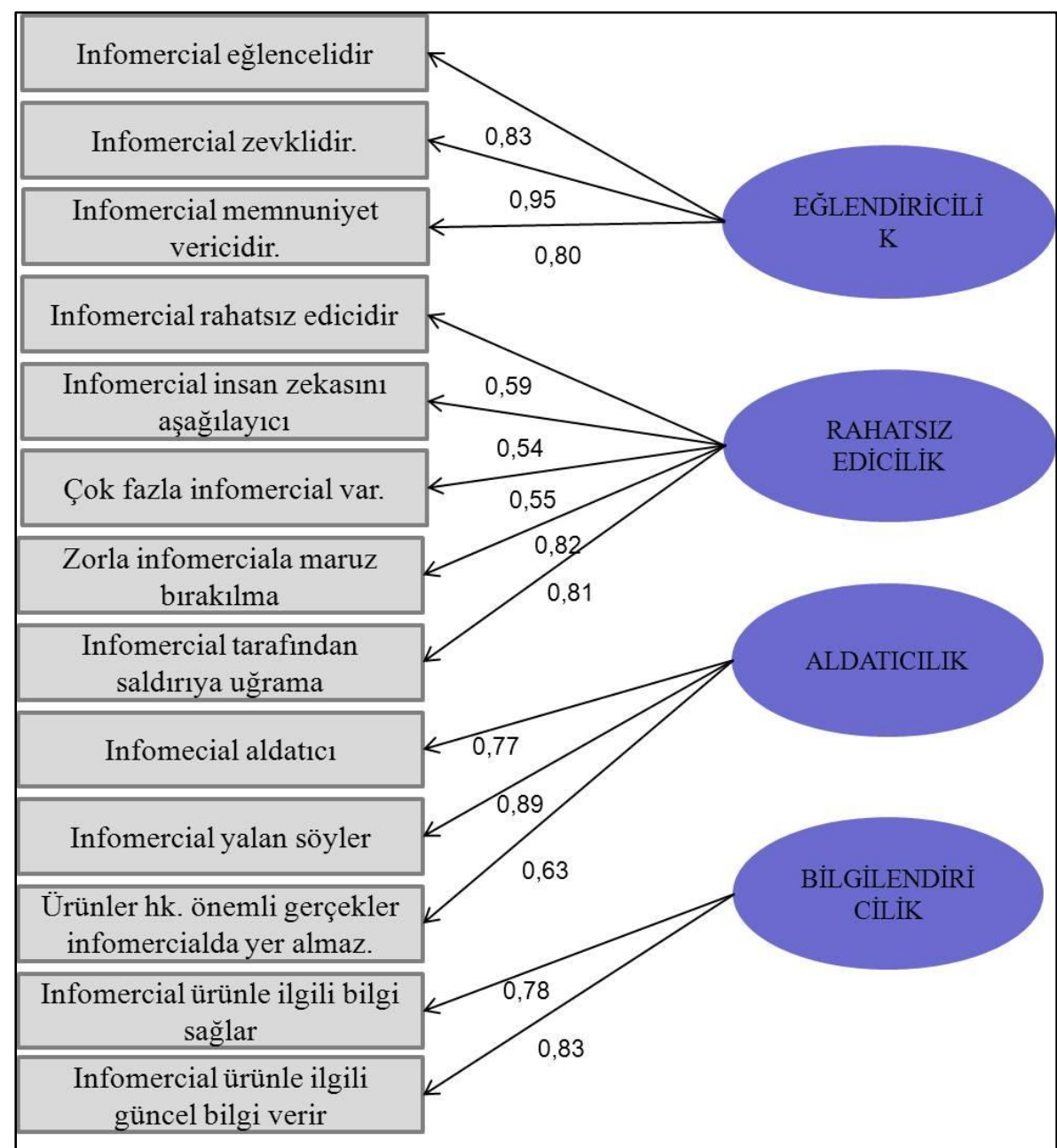

Doğrulayıc1 faktör analizinde faktör yükü standardize edilmiş parametre değeri olarak karşımıza çıkmaktadır. Bu değer 0,50’nin üzerinde olduğunda kabul edilebilir. Örneğin faktör analizinden elde ettiğimiz bilgilendiricilik faktörünü açıklayan S10(Infomercial reklamlar ürünle ilgili bilgiyi, insanlar ürünler hakkında bilgiye ihtiyaç duyduğu zaman verir) $=0,43$ değerini alarak 0,5 'in altında kaldığı için modelden çıkarılarak analiz tekrar edilmiştir. Böylece güvenilirliğin arttığı gözlemlenmiştir. 


\section{Şekil 25: Alıcının Kişilik Özellikleri Lisrel Çıktısı}

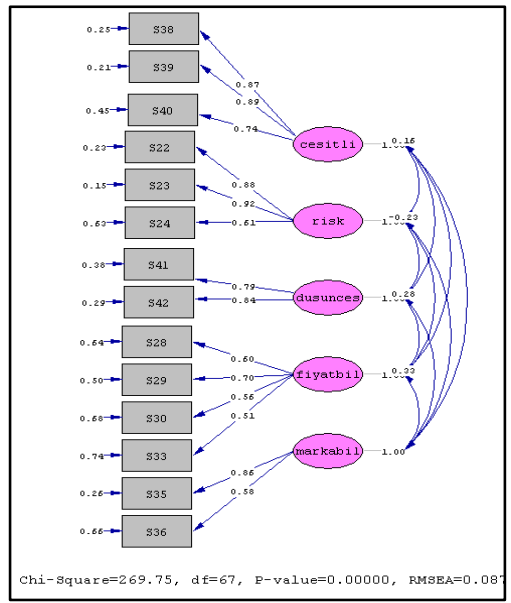

Şekil 26: Alıcının Kişilik Özellikleri Ölçeği

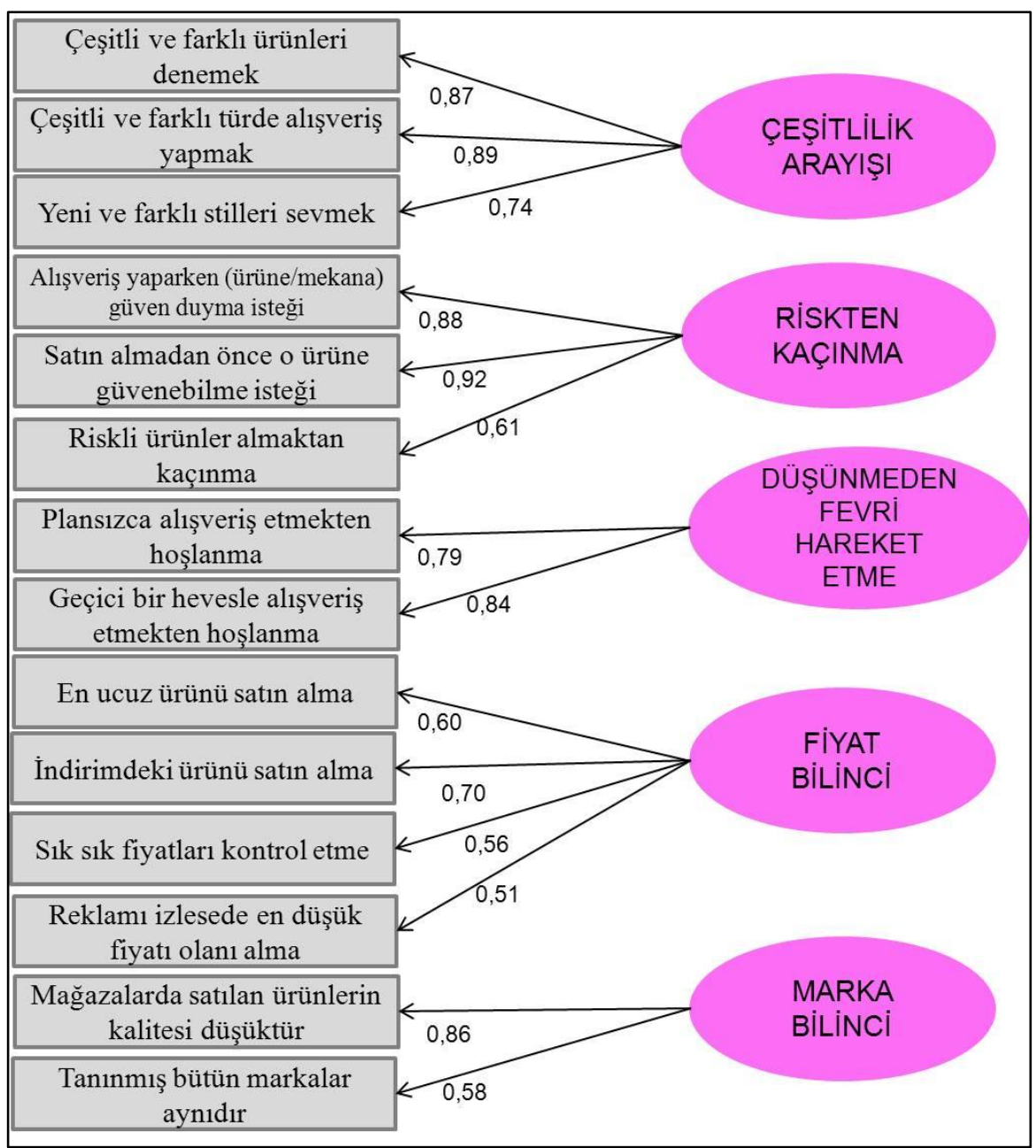

Açıklayıcı faktör analizinden elde ettiğimiz alıcının kişilik özelliklerini oluşturan düşüncesizce/fevri hareket etme faktöründeki S43 (Alışveriş etmeden önce iki kere düşünürüm) ve S44 (daima alışveriş listeme sadık kalırım) doğrulayıcı faktör analizindeki faktör yüklerinin 0,5 'in altında kalması nedeniyle analizden çıkarılmıştır. Böylece güvenilirliğin arttığg gözlemlenmiştir. 


\section{Şekil 27: Infomercial Reklam İçeriği Lisrel Çıktısı}

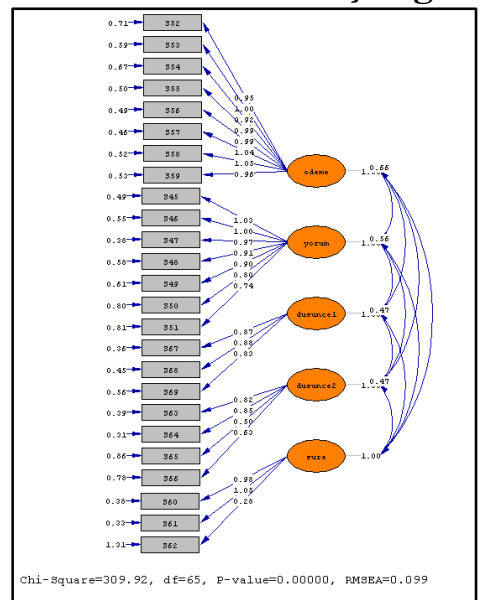

\section{Şekil 28: Infomercial Reklam İçeriği Ölçeği}

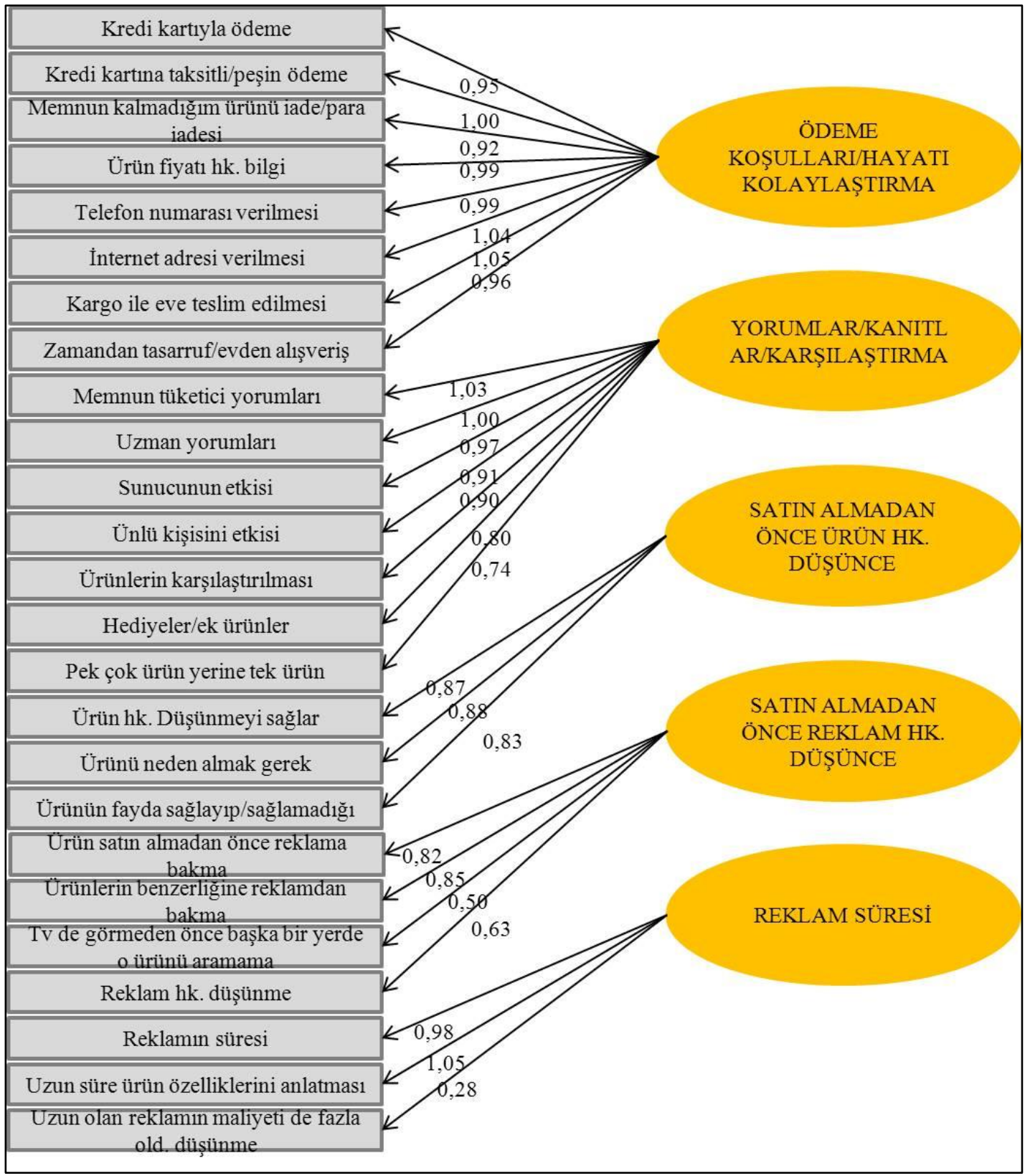


Tablo 31: Modeldeki Değişkenlere Ait Uyum İndeksleri

\begin{tabular}{|c|c|c|c|c|c|c|c|c|}
\hline & FAKTÖR & $\begin{array}{l}\text { GFI } \\
>\mathbf{0 , 9 0}\end{array}$ & $\begin{array}{l}\text { AGFI } \\
\mathbf{> 0 , 8 5}\end{array}$ & $\begin{array}{l}\text { CFI } \\
\mathbf{> 0 , 9 0}\end{array}$ & $\begin{array}{l}\text { NFI } \\
>\mathbf{0 , 9 0}\end{array}$ & $\begin{array}{l}\text { RFI } \\
>\mathbf{0 , 8 5}\end{array}$ & $\begin{array}{l}\text { RMSEA } \\
<\mathbf{0 , 1 0}\end{array}$ & $\begin{array}{l}\text { SRMR } \\
<\mathbf{0 , 1 0}\end{array}$ \\
\hline $\begin{array}{c}\text { Infomercial Reklama } \\
\text { Yönelik Algl }\end{array}$ & 4 & 0,90 & 0,85 & 0,91 & 0,89 & 0,85 & 0,09 & 0,07 \\
\hline $\begin{array}{c}\text { Alıcının Kisilik } \\
\text { Özellikleri }\end{array}$ & 5 & 0,91 & 0,86 & 0,90 & 0,90 & 0,84 & 0,08 & 0,07 \\
\hline $\begin{array}{c}\text { Infomercial Reklam } \\
\text { Icceriği }\end{array}$ & 5 & 0,79 & 0,74 & 0,74 & 0,81 & 0,79 & 0,09 & 0,05 \\
\hline
\end{tabular}

*Bir faktörün yeterince güvenilir olduğunu iddia edebilmek için $\operatorname{RMSEA}<0,10$; SRMR $<0,10 ; \quad$ AGFI $>0,85, \quad$ RFI $>0,85 ; \quad$ GFI $>0,90 ; \quad$ CFI $>0,90 ; \quad$ NFI $>0,90$ değerleri sağlanmalıdır.

Her değişken için elde edilen güven indeksleri Tablo 31'de gösterilmiştir. Buradaki değerlerden en önemli iki tanesini açıklamak gerekirse; GFI (Uyum İyiliği İndeksi), çoklu regresyon katsayısına benzemektedir ve varsayılan modelce hesaplanan gözlenen değişkenler arasındaki genel kovaryans miktarını gösterir. NFI (Normlanmış Uyum İndeksi), H0 ile karşılaştırıldığında modeli kullanarak elde edilen uygunluktaki artış miktarını gösterir. Bir faktörün yeterince güvenilir olduğunu iddia edebilmek için bu faktörde RMSEA $<0,10$; SRMR $<0,10$; AGFI $>0,85$, RFI $>0,85$; GFI $>0,90$; CFI $>0,90$; NFI $>0,90$ değerleri sağlanmalıdır. Modelin güvenilirlik değerleri infomercial reklama yönelik algı ve alıcının kişilik özellikleri için tamamen sağlanmıştır. Infomercial reklam içeriğinin ise en önemli güvenilirlik değerleri istenilen düzeyde çıkmamıştır. Yani bu faktör doğrulayıcı faktör analizinden geçememiştir.

\subsubsection{Araştırma Sonuçlarının Yapısal Eşitlik Modeliyle Analizi}

Gözlenen değişkenler arasındaki kovaryans yapısı, modeldeki tüm değişkenler arasındaki doğrusal yapısal ilişkileri araştırmak için kullanılır. Sosyal ve davranış bilimlerinde böyle modeller "nedensel" modeller olarak isimlendirilir ve bir doğrusal yapısal modelden türetilen belirgin değişkenlerin kovaryans matrisinin analizini içerir. YEM özellikle, değişkenler arasındaki ilişkilerin değerlendirilmesinde, kuramsal modellerin geliştirilmesi ve sınanmasında yaygın olarak kullanılır. Hem sosyal, davranış ve eğitim ile ilgili bilimsel araştırmalarda hem de biyoloji, pazarlama ve tıp araştırmalarında kullanılan bir istatiksel yöntem bilimidir. (YILMAZ, et al., 2009 s. 5)

YEM modelleri araştırmacılara, değişkenler arasında doğrudan ve dolaylı etkileri belirleme olanağı sağlamaktadır. YEM, basit doğrusal regresyon analizine 
benzemekle birlikte, kuramsal yapılar arasındaki etkileşimleri, yapılara ölçme hatalarını ve hatalar arasındaki ilişkileri dâhil ederek modelleyen çok değişkenli istatiksel bir yaklaşımdır. YEM modellerinin ölçme hatalarını açık bir şekilde hesaba katmasına ilişkin güçlü karakteristiği, yapılar arasındaki etkileşimlerin ayrıntılı olarak ele alınmasına imkân vermektedir. (YILMAZ, et al., 2009 s. 5)

YEM istatiksel bağımlılığa dayalı modellerle ilgili karma hipotezlerin içindeki değişkenlerin sebep sonuç ilişkisini açıklayabilen ve teorik modellerin bir bütün olarak test edilmesine olanak veren etkili bir model test etme ve geliştirme yöntemidir. Araştırmacının zihnindeki, araştırma henüz yapılmadan önce var olan değiş̧kenler arası ilişsilere ait bir modelin, araştırmadan elde edilen veriler aracılığıyla sınanmasına dayanmaktadır. Varyans analizi, faktör analizi, MANOVA, regresyon gibi daha alışılmış istatistiki yöntemlerden en büyük farkı çok sayıda değişken arasındaki ilişkiyi modeller şeklinde inceleyebilmesidir. Birçok değişken setini ve ilişkilerini içeren modellerin test edilmesi sırasında alışılmış ANOVA, regresyon gibi analizleri ayrı ayrı yapılırken her aşamada hata payı katlanarak birikmekte ve nihai kararda yüzde 5 ya da yüzde 1 olması gereken 1. Tip hata oranı analiz adımlarının sayısına bağlı olarak çok daha yüksek olmaktadır. Ayrıca bu analiz adımları takip edilirken, modelin bütünlüğü, yani değişkenlerin birlikte ilişkileri göz ardı edilmektedir. Oysa YEM analizi bahsedilen hata payını düşürmekte ve değişkenlerin birlikte ilişkilerini bir bütün olarak modeli analiz etmektedir. Çoklu regresyona benzeyen YEM analizinin güçlü olmasının sebebi, modeldeki doğrusal olmayan ilişkileri, aracılık etkilerini, ilişkili bağımsız değişkenleri, aracılık etkilerini, ilişkili bağımsız değişkenleri, ölçme hatalarını, ilişkili hata terimlerini, her biri birkaç gösterge ile ölçülen birçok örtük bağımsız değişkeni, çoklu göstergeli bir ya da daha fazla örtük değişkeni hesaba katabilmesidir. (ÇAKIR, et al., 2007 s. 45-46)

Yapısal eşitlik modelleri değişkenler arasındaki kompleks kovaryans yapısının, faktör analizi ve eşanlı yapısal modellerden yararlanarak analiz edilmesine olanak sağlar. Yapısal eşitlik modelleri, gözlenen değişkenlerle örtük değişkenlerin ilişkilerini belirleyen ölçme modelleri ve örtük değişkenlerin birbirleri arasındaki ilişkileri belirleyen yapısal modellerin (örtük değişken modeli) kombinasyonundan meydana gelmektedir. (NOYAN, 2009 s. 18)

YEM, hem örtük değişkenleri gözlenen değişkenlerle ilişkilendirerek ölçmekte, hem de örtük değişskenler arasındaki nedensel ilişkileri kestirmektedir. Böylece, ölçüm hatalarının, örtük bağımlı değişkenlerin, örtük değişkenler arasındaki ilişkilerin 
kestirilmesine, test edilmesine ve model uyum ölçütlerinin üretilmesine olanak sağlamaktadır. (NOYAN, 2009 s. 21)

Açıklayıcı ve doğrulayıcı faktör analizleri yapılarak uygun bir ölçme modeli elde edilmiştir. Modelde yer alan değişkenler arasındaki nedensel ilişkiler örtük değişkenlerle yol analizi yapılarak belirlenir. Şekil 26'da modelin iterasyondan önceki en son hali yer almaktadır. Bağımlı değişkenler üzerindeki, regresyon ilişki düzeyi düşük olan, bazı örtük değişkenler modelden çıkarılmış, böylece daha güvenli sonuçlar elde edilmiştir. İterasyonlar sonucunda elde edilen en iyi modeller ve bu modellere ait uyum indeksleri aşağıda incelenecektir. 


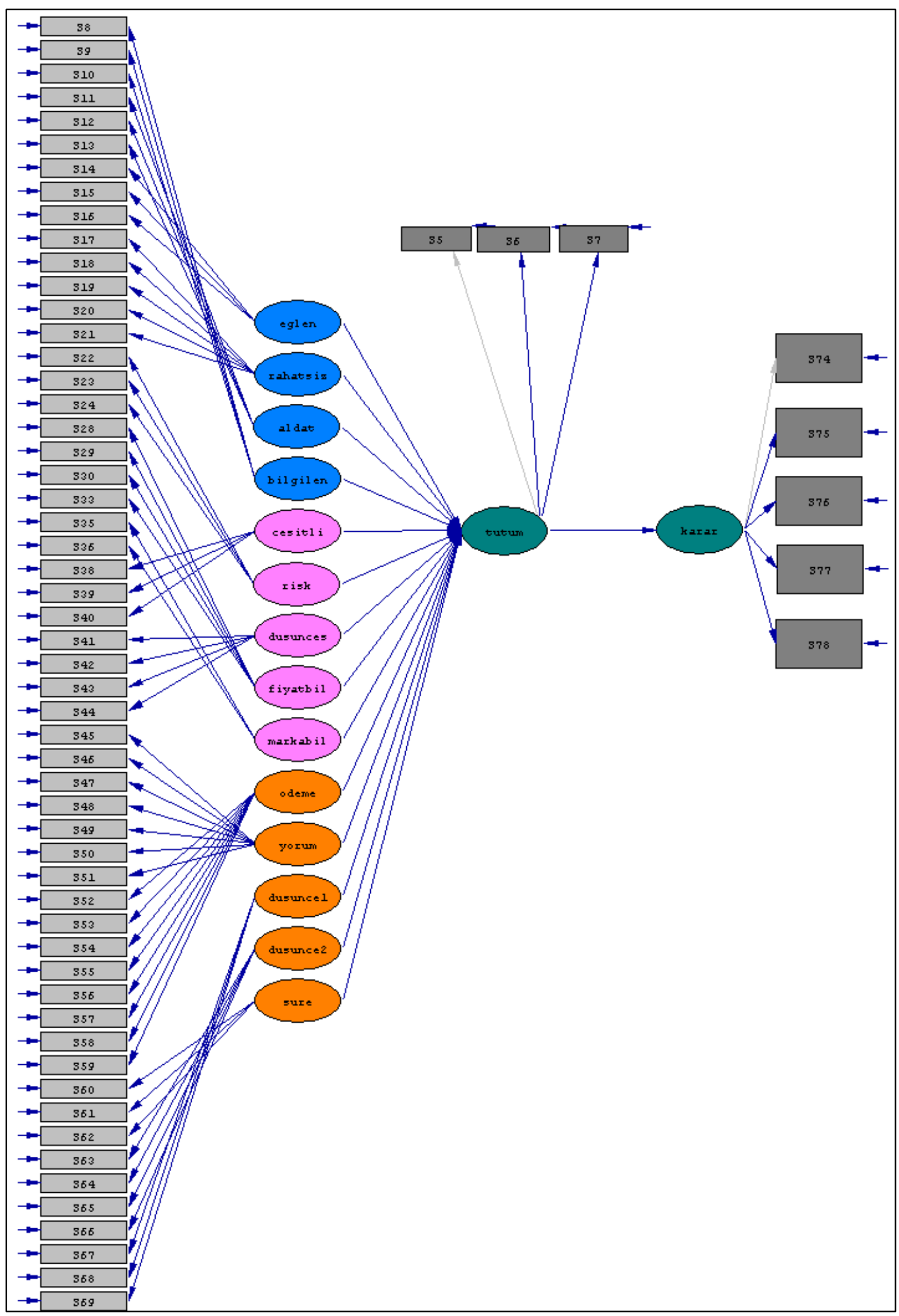

Şekil 29: Açıklayıcı ve Doğrulayıcı Faktör Analizlerinin Ardından Modelin İterasyondan Önceki En Son Hali

Not: Şekil 10'daki modelin lisrel çıktısıdır. 
Başlangıçta önerilen model aracı bir modeldir. Yani algı, kişilik özellikleri ve reklam içeriğinin tutumu etkilediği ve satın alma kararının ise tutum değişkeni ile sağlandığı öngörülmektedir. Bu örtük değişkenlerle gerçekleştirilecek bir yol analizinin, değişkenler arasındaki sebep-sonuç ilişkilerinin teorik olarak tahmin edildiği gibi olup olmadığı sorusuna cevap vermesi beklenmektedir. Böylece daha iyi bir model olup olmadığını araştırmak için alternatif modeller denenmiştir. (ÖZDEMİRĊ, 2010)

İlk olarak infomercial reklama yönelik algıyı oluşturan; eğlendiricilik, rahatsız edicilik, aldatıcılık ve bilgilendiricilik, faktörlerinin tutumu etkilediği ve bunun üzerinden satın alma kararının etkilendiği model incelenmiştir. Burada rahatsız edicilik örtük değişkeni ve reklam tutumu arasındaki yollara ilişkin t-değerine göre aralarında bir ilişki bulunamamıştır. $\mathrm{Bu}$ yol analizden çıkarılıp, analiz tekrar edilmiştir. $\mathrm{Bu}$ bağlamda eğlendiricilik - tutum arasında $(0,53)$ pozitif bir ilişki, aldatıcılık - tutum arasında $(-0,21)$ negatif ilişki ve bilgilendiricilik - tutum arasında $(0,34)$ pozitif bir ilişki görülmüştür. Modelin kabul edilebilirliğini test etmek amacıyla, uyum indekslerine bakıldığında ise değerlerin kabul edilebilir sınırlar içerisinde olduğu görülmüştür. Bilgilendiricilik, eğlendiricilik ve aldatıcılık değişkenlerinin infomercial reklam tutumu üzerinde doğrudan etkilerinin incelendiği model Şekil: 30/31'de gösterilmektedir. 


\section{Şekil 30: Tutumu Etkileyen Infomercial Reklama Yönelik Algı Faktörlerinin}

İterasyon Aracılığıyla En İyi Değerleri Aldığı Modelin Lisrel Çıktısı

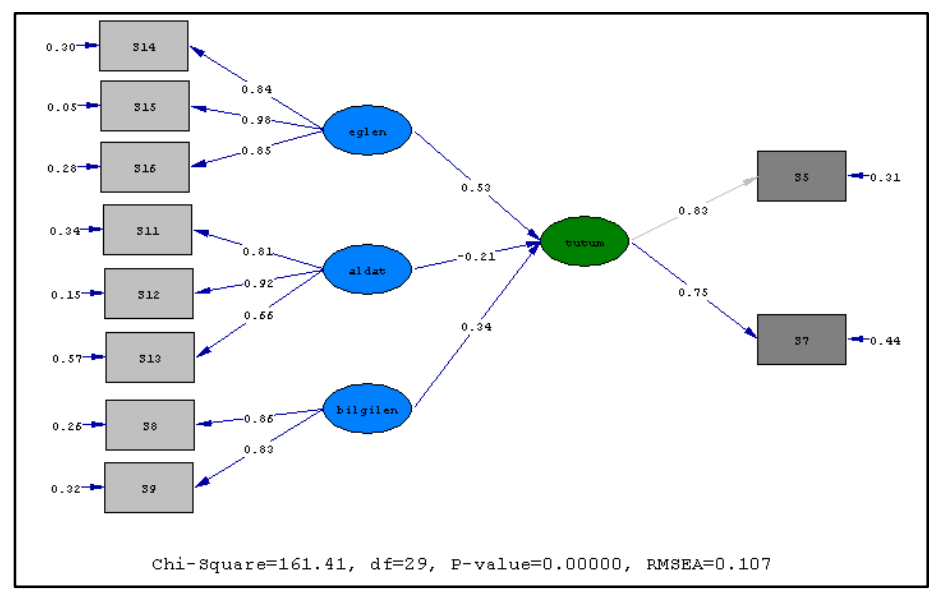

Şekil 31:Tutumu Etkileyen Infomercial Reklama Yönelik Algı Faktörlerinin İterasyon Aracılığıyla En İyi Değerleri Aldığı Model

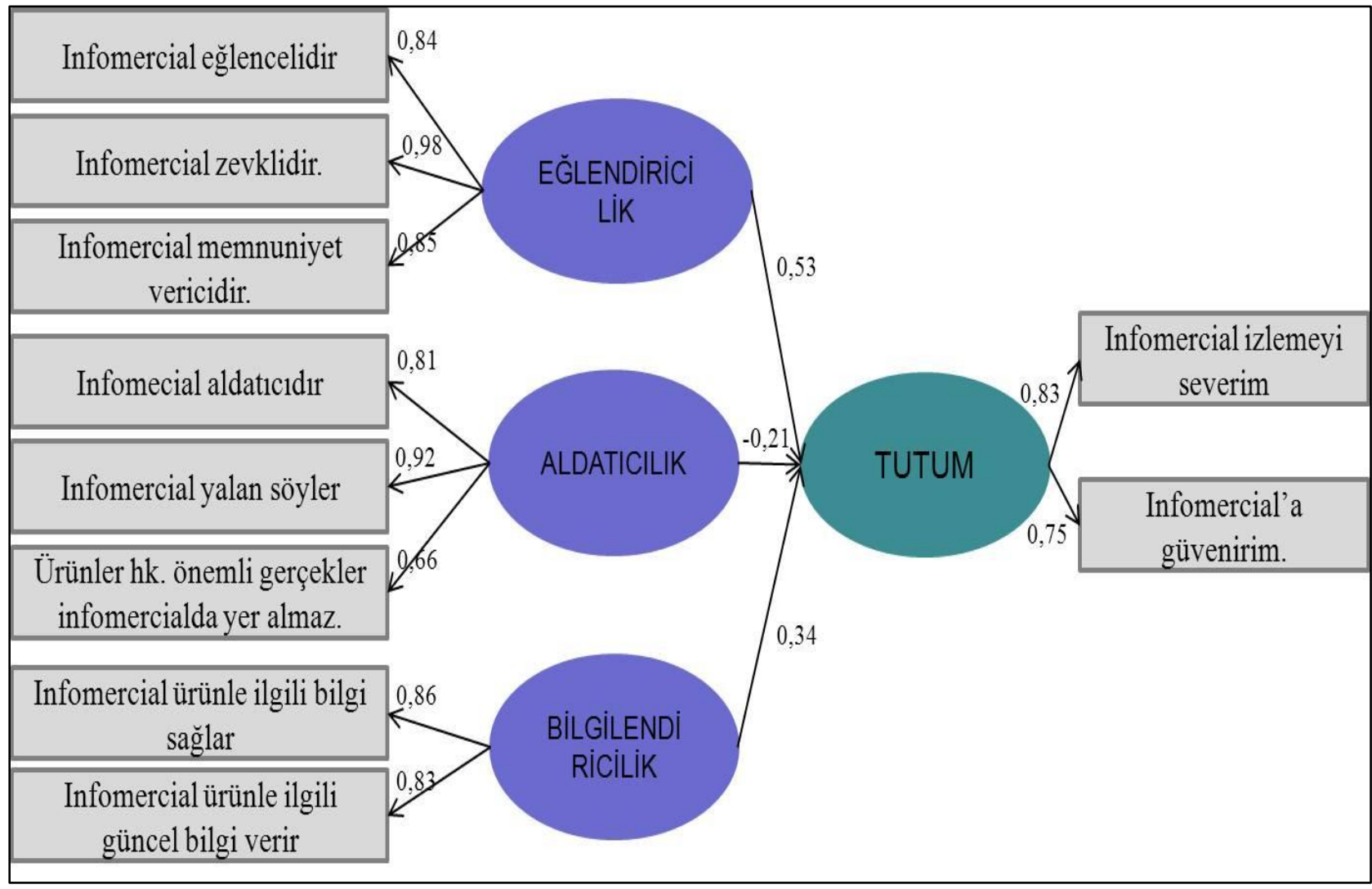

$\mathrm{Bu}$ model Çakırlar'ın çalışmasıyla benzerlik göstermektedir. Araştırmanın bulgularının değerlendirilmesi kısmında iki modelin karşılaştırılması yapılacaktır. 
Açıklayıcı ve doğrulayıcı faktör analizinden sonra elde edilen alıcının kişilik özelliklerine ait alt boyutlardan risk, çeşitlilik ve marka bilinci faktörleri ile tutum arasındaki yollara ilişkin t-değerlerine göre aralarında bir ilişki bulunamamıştır. $\mathrm{Bu}$ nedenle bu yollar analizden çıkarılmıştır. Düşüncesizce / fevri hareket etme - tutum arasında $(0,20)$ pozitif bir ilişki, fiyat bilinci - tutum arasında da $(0,22)$ pozitif bir ilişki olduğu görülen model Şekil 32/33'de gösterilmektedir.

\section{Şekil 32: Tutumu Etkileyen Alıcının Kişilik Özellikleri Faktörlerinin İterasyon}

\section{Aracılığıyla En İyi Değerleri Aldığı Modelin Lisrel Çıktısı}

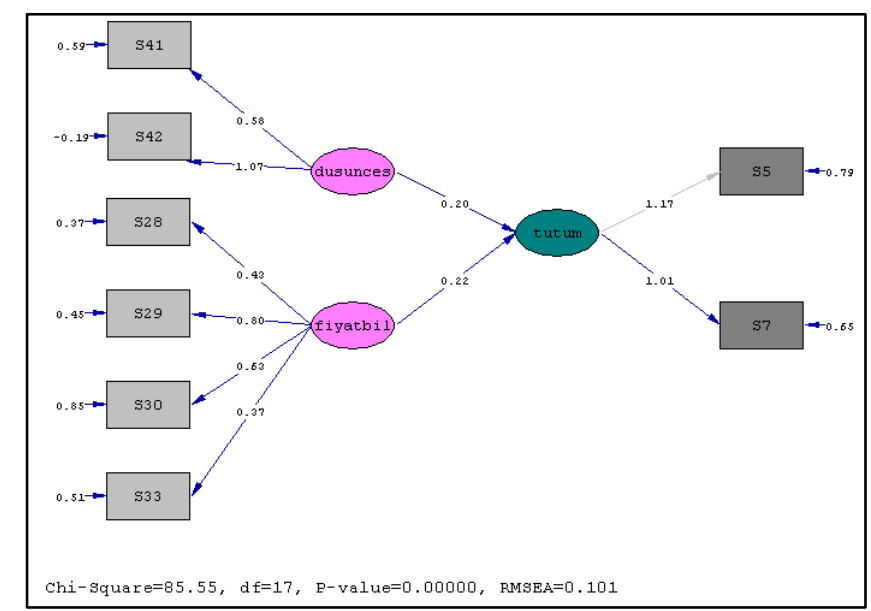

Şekil 33:Tutumu Etkileyen Alıcının Kişilik Özellikleri Faktörlerinin İterasyon Aracılığıyla En İyi Değerleri Aldığı Model

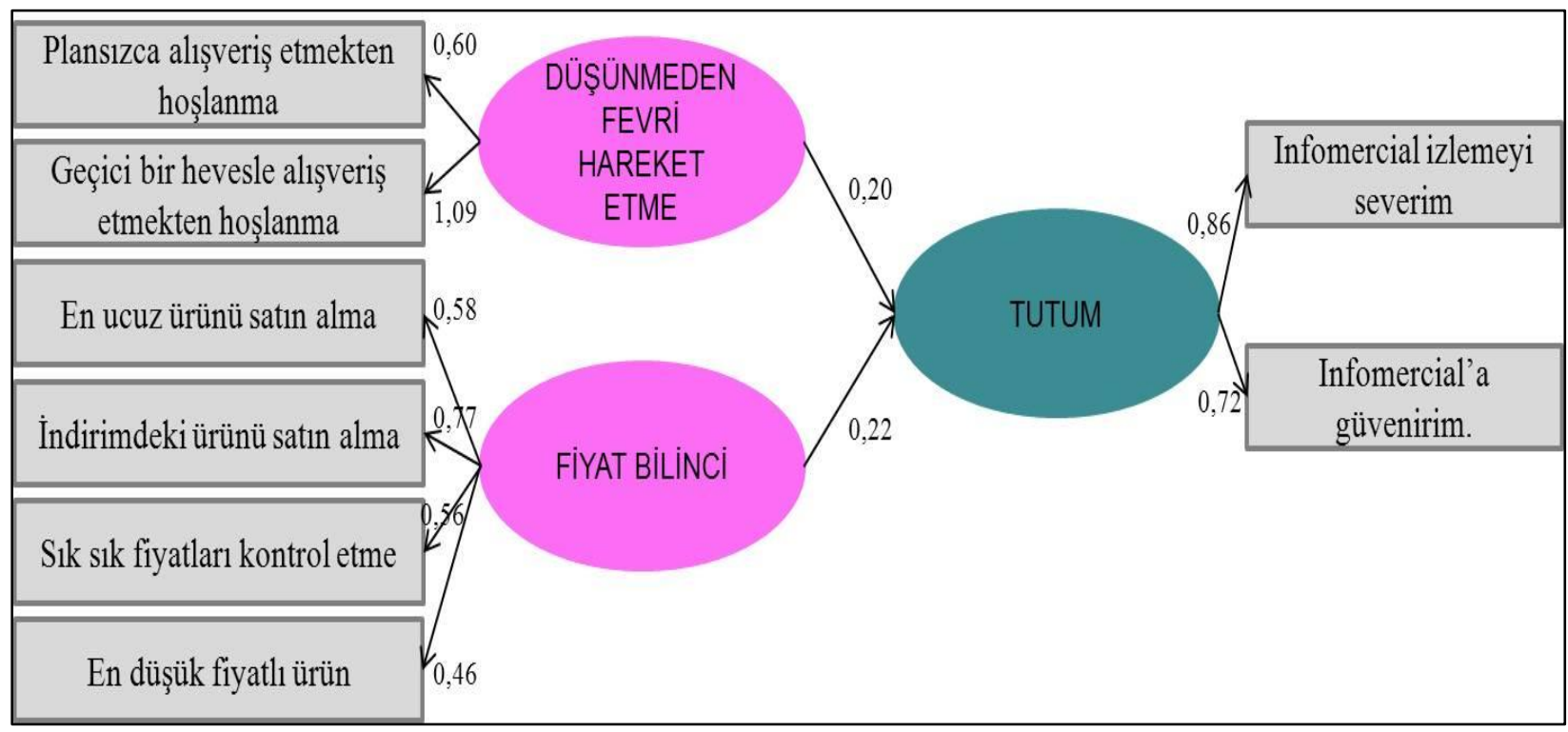


Tablo 32: Modeldeki Değişkenlere Ait Uyum İndeksleri

\begin{tabular}{|l|c|c|c|c|c|c|c|c|c|}
\hline & $\begin{array}{c}\text { Bağımı ı } \\
\text { değişken }\end{array}$ & $\begin{array}{c}\text { Bağımsız } \\
\text { değişken }\end{array}$ & $\begin{array}{c}\text { GFI } \\
\mathbf{> 0 , 9 0}\end{array}$ & $\begin{array}{c}\text { AGFI } \\
\mathbf{> 0 , 8 5}\end{array}$ & $\begin{array}{c}\text { SRMR } \\
\mathbf{< 0 , 1 0}\end{array}$ & $\begin{array}{c}\text { RFI } \\
\mathbf{8 0 , 8 5}\end{array}$ & $\begin{array}{c}\text { CFI } \\
\mathbf{> 0 , 9}\end{array}$ & $\begin{array}{c}\text { NFI } \\
\mathbf{> 0 , 9 0}\end{array}$ & $\begin{array}{c}\text { RMSEA } \\
<\mathbf{0 , 1 0}\end{array}$ \\
\hline $\begin{array}{l}\text { Tutumu Etkileyen } \\
\text { Infomercial Reklama } \\
\text { Yönelik Algı Modeli }\end{array}$ & Tutum & $\begin{array}{c}\text { Eğlen } \\
\text { Aldat } \\
\text { Bilgilen }\end{array}$ & 0,92 & 0,85 & 0,07 & 0,89 & 0,94 & 0,93 & 0,10 \\
\hline $\begin{array}{l}\text { Tutumu Etkileyen } \\
\text { Alıcının Kişilik } \\
\text { Özellikleri Modeli }\end{array}$ & Tutum & $\begin{array}{c}\text { Dusuncesiz } \\
\text { fiyatbil }\end{array}$ & 0,95 & 0,89 & 0,06 & 0,82 & 0,91 & 0,90 & 0,10 \\
\hline
\end{tabular}

Yapısal eşitlik modeline tabi tuttuğumuz modelimiz incelendiğinde, tutumu etkileyen iki ayrı model elde edilmiştir. Buna rağmen hiçbir faktörün ne doğrudan ne dolaylı olarak gelecekteki satın alma kararını etkilemediği görülmektedir. Bu iki model arasından literatürdekiyle daha yakından ilgili olduğu için ilk model, yani algı modeli değerlendirmeye alınmıştır.

\subsubsection{Araştırmanın Hipotezleri ve Hipotezlerin Test Edilmesi}

Araştırma sonuçlarının analizinde parametrik testleri kullanıp kullanamayacağımızı belirlemek için elde edilen verilere Kolmogorov Smirnov testi uygulanmış ve örneklemin normal dağılıma sahip olduğu sonucuna varılmıştır. Örneklem sayısının 30'un üzerinde olması, faktör varyanslarının eşit olduğu kabulü ve gözlenen değişkenlerin normal dağılıma uyması sonucunda verilerin parametrik testler aracılığıyla analiz edilmesinde bir sorun bulunmamaktadır.

Bu bölümde faktör analizi sonucu ortaya çıkan on dört faktör ile demografik değişkenler ve televizyon izleme alışkanlıkları arasındaki farklılıklar incelenecektir. Ankette yer verilen demografik özelliklere göre yapılan analiz sonucunda, cinsiyet, yaş, medeni durum, haneye giren aylık gelir arasında farklılıklara rastlanırken, eğitim, aylık gelir ve çocuk sayısı faktörlere göre farklılık testlerine tabi tutulmuş olmasına rağmen anlamlı bir farklılık görülmediği için çalışmada yer verilmemiştir.

Cinsiyet Gruplarının Farklılığının Test Edilmesi: Burada yapılan testlerin amacı erkeklerle kadınlar arasında "eğlendiricilik", "rahatsız edicilik", "aldatıcılık", "bilgilendiricilik", “çeşitlilik, risk”, “düşünmeden/ fevri hareket etme”, “fiyat bilinci”, "marka bilinci”, "satın almadan önceki ürün hakkındaki düşünce”, "satın almadan önceki reklam hakkındaki düşünce”, “ödeme şekli ve hayatı kolaylaştırma”, "reklam süresi”, "yorumlar-kanıtlar ve karşılaştırma" faktörleri açısından bir fark olup olmadığının belirlenmesidir. 
$\mathbf{H}_{\mathbf{0}}$ : Faktörler açısından kadınlarla erkekler arasında anlamlı bir fark yoktur.

$\mathbf{H}_{1}$ : Faktörler açısından kadınlarla erkekler arasında anlamlı bir fark vardır.

Tablo 33: Algı, Kişilik ve Reklam İçeriği Alt Boyutlarının Cinsiyete Göre Dağılımı

\begin{tabular}{|c|c|c|c|c|c|c|c|c|}
\hline & & Cinsiyet & $\mathbf{N}$ & Ort. & S.S. & Levene & T testi & $P$ değeri \\
\hline \multirow{8}{*}{$\begin{array}{l}\text { INFOMERCIAL } \\
\text { REKLAMA } \\
\text { YÖNELIK ALGI }\end{array}$} & \multirow{2}{*}{ Eğlendiricilik } & Erkek & 186 & 2,61 & 1,05 & \multirow{2}{*}{0,336} & $-1,302$ & \multirow{2}{*}{$\begin{array}{l}0,194 \\
0,193\end{array}$} \\
\hline & & Kadın & 214 & 2,75 & 1,07 & & $-1,304$ & \\
\hline & \multirow{2}{*}{$\begin{array}{l}\text { Rahatsiz } \\
\text { Edicilik }\end{array}$} & Erkek & 186 & 3,18 & 0,85 & \multirow{2}{*}{0,319} & $-0,248$ & \multirow{2}{*}{$\begin{array}{l}0,804 \\
0,803\end{array}$} \\
\hline & & Kadın & 214 & 3,21 & 0,90 & & $-0,249$ & \\
\hline & \multirow{2}{*}{ Aldatıcılık } & Erkek & 186 & 3,16 & 0,92 & \multirow{2}{*}{0,615} & 0,376 & \multirow{2}{*}{$\begin{array}{l}0,707 \\
0,708\end{array}$} \\
\hline & & Kadın & 214 & 3,13 & 0,89 & & 0,375 & \\
\hline & \multirow{2}{*}{ Bilgilendiricilik } & Erkek & 186 & 3,11 & 0,82 & \multirow{2}{*}{0,442} & $-1,368$ & \multirow{2}{*}{$\begin{array}{l}0,172 \\
0,171\end{array}$} \\
\hline & & Kadın & 214 & 3,23 & 0,85 & & $-1,371$ & \\
\hline \multirow{10}{*}{$\begin{array}{c}\text { ALICININ } \\
\text { KISSILIIK } \\
\text { ÖZELLIKLERI }\end{array}$} & \multirow{2}{*}{ Çeşitlilik } & Erkek & 186 & 3,30 & 0,85 & \multirow{2}{*}{0,021} & $-1,928$ & \multirow{2}{*}{$\begin{array}{l}0,055 \\
0,057\end{array}$} \\
\hline & & Kadın & 214 & 3,46 & 0,75 & & $-1,911$ & \\
\hline & \multirow{2}{*}{ Risk } & Erkek & 186 & 4,33 & 0,69 & \multirow{2}{*}{0,647} & $-0,035$ & \multirow{2}{*}{$\begin{array}{l}0,972 \\
0,972\end{array}$} \\
\hline & & Kadın & 214 & 4,34 & 0,68 & & $-0,035$ & \\
\hline & \multirow{2}{*}{$\begin{array}{l}\text { Düşünmeden/ } \\
\text { Fevri Hareket } \\
\text { Etme }\end{array}$} & Erkek & 186 & 2,93 & 0,59 & \multirow{2}{*}{0,863} & $-0,968$ & \multirow{2}{*}{$\begin{array}{l}0,333 \\
0,334\end{array}$} \\
\hline & & Kadın & 214 & 2,98 & 0,57 & & $-0,966$ & \\
\hline & \multirow{2}{*}{ Fiyat Bilinci } & Erkek & 186 & 2,98 & 0,72 & \multirow{2}{*}{0,762} & $-0,218$ & \multirow{2}{*}{$\begin{array}{l}0,827 \\
0,827\end{array}$} \\
\hline & & Kadın & 214 & 3,00 & 0,71 & & $-0,218$ & \\
\hline & \multirow{2}{*}{ Marka Bilinci } & Erkek & 186 & 2,45 & 0,79 & \multirow{2}{*}{0,584} & 0,526 & \multirow{2}{*}{$\begin{array}{l}0,599 \\
0,598\end{array}$} \\
\hline & & Kadın & 214 & 2,41 & 0,84 & & 0,528 & \\
\hline \multirow{10}{*}{$\begin{array}{c}\text { INFOMERCIAL } \\
\text { REKLAM } \\
\text { IÇERİĞİ }\end{array}$} & Ödeme Şekli Ve & Erkek & 186 & 3,15 & 1,00 & 0851 & $-0,670$ & 0,504 \\
\hline & Kolaylaştırma & Kadın & 214 & 3,22 & 1,04 & 0,8 & $-0,671$ & 0,502 \\
\hline & Yorumlar- & Erkek & 186 & 2,63 & 0,94 & 0927 & $-1,933$ & 0,054 \\
\hline & Karşılaştırma & Kadın & 214 & 2,81 & 0,95 & 0,927 & $-1,934$ & 0,054 \\
\hline & Satın Almadan & Erkek & 186 & 3,11 & 0,98 & & $-3,367$ & 0,001 \\
\hline & $\begin{array}{l}\text { Onceki Urun } \\
\text { hk. Düşünce }\end{array}$ & Kadın & 214 & 3,42 & 0,87 & 0,052 & $-3,340$ & 0,001 \\
\hline & Satın Almadan & Erkek & 186 & 2,77 & 0,81 & & $-0,536$ & 0,592 \\
\hline & $\begin{array}{l}\text { Uncek1 Reklam } \\
\text { hk. Düşünce }\end{array}$ & Kadın & 214 & 2,82 & 0,78 & 0,816 & $-0,534$ & 0,593 \\
\hline & & Erkek & 186 & 2,74 & 0,90 & & 0,574 & 0,566 \\
\hline & & Kadın & 214 & 2,69 & 0,90 & & 0,574 & 0,566 \\
\hline
\end{tabular}


Cinsiyete göre faklılık testi (independent samples t test) yapılırken öncelikle homojenlik araştırılır. Levene testi kullanılarak ilk olarak varyanslarının eşit olup olmadığı test edilir.

$\mathbf{H}_{\mathbf{0}}$ : Her iki grubun varyansları eşittir.

$\mathbf{H}_{1}$ : Her iki grubun varyansları eşit değildir.

Levene testi sonucunda $\mathrm{p}$ değeri 0,05 'den küçük olduğu durumda $\mathrm{H}_{0}$ hipotezi reddedilir. "Satın almadan önceki birinci tip düşünce" faktörünün Levene testindeki p değeri $0,052>0,05$ olduğu görülür ve $\mathrm{H}_{0}$ hipotezi kabul edilir. $\mathrm{Bu}$ durumda ilk satırda yer alan sig değerine bakılır.

$\mathbf{H}_{\mathbf{0}}$ : Satın almadan önceki ürün hakkındaki düşünce açısından kadınlarla erkekler arasinda anlamlı bir fark yoktur.

$\mathbf{H}_{26 \mathrm{~A}}$ : Satın almadan önceki ürün hakkındaki düşünce açısından kadınlarla erkekler arasında anlamlı bir fark vardır.

T testi hipotezine bakıldığında ise, $\mathrm{p}$ değeri $0,001<0,05$ olduğu için $\mathrm{H}_{0}$ red, $\mathrm{H}_{1}$ hipotezi ise kabul edilmiştir ( $\mu$ kadın=3,42 ve $\mu$ erkek=3,11)

BULGU: Yapılan analiz sonucunda kadınların tanitıcı reklamlardan satın almaya karar vermeden önce ürün hakkında erkeklere göre daha fazla düşündükleri belirlenmiştir. Eğlendiricilik, rahatsız edicilik, aldatıcılık, bilgilendiricilik, çeşitlilik, risk, düşünmeden/ fevri hareket etme, fiyat bilinci, marka bilinci, satın almadan önceki reklam hakkındaki düşünce, ödeme şekli ve hayatı kolaylaştırma, reklam süresi ve yorumlar/kanıtlar/karşılaştırma faktörlerinde ise $\mathrm{H}_{0}$ hipotezi kabul edilmiş, hiçbir farklılı̆̆ın olmadı̆̆ı anlaşılmıştır.

Yaş Gruplarının Farklılı̆̆ııın Test Edilmesi: Yaş grupları (16-24), (25-34), (35-44), (45-54), (55-64), (65 ve üzeri) olmak üzere altı tanedir. "Eğlendiricilik", “rahatsız edicilik", “aldatıcılık”, “bilgilendiricilik", “çeşitlilik”, “risk”, “düşünmeden/ fevri hareket etme”, “fiyat bilinci”, "marka bilinci”, "satın almadan önceki ürün hakkındaki düşünce”, "satın almadan önceki reklam hakkındaki düşünce”, "ödeme şekli ve hayatı kolaylaştırma", "reklam süresi”, “yorumlar/kanıtlar/karşılaştırma” faktörleri açısından bu gruplar arasında farklılığın bulunup bulunmadığını belirlemek amacıyla tek yönlü varyans analizi ANOVA testinden yararlanılmıştır. Test sonuçları ve hipotezler aşağıdaki gibidir.

$\mathbf{H}_{\mathbf{0}}$ : Faktörler açısından yaş grupları arasında anlamlı bir fark yoktur.

$\mathbf{H}_{1}$ : Faktörler açısından yaş grupları arasında anlamlı bir fark vardır. 
Levene testi sonuçlarına göre $p$ değeri $>0,05$ olan faktörler ile ANOVA testine başlanır. Anlamlılığın nerden kaynakladığını analiz etmek için ise Tukey ve Scheffe testinden yararlanılır.

Aşağıdaki Tablo 32'de Scheffe testine göre anlamlı bir farklılık görülen faktörlerin sonuçları yer alacaktır.

Tablo 34: Bilgilendiricilik Faktörünün Yaş Gruplarına Göre Dağılımı

ANOVA testi Sonucu

\begin{tabular}{|c|c|c|c|c|c|c|c|c|}
\hline & Yaş & $\mu$ & & $\begin{array}{l}\text { Ortalama } \\
\text { Farkı }\end{array}$ & $\begin{array}{c}\text { Standart } \\
\text { Hata }\end{array}$ & $\begin{array}{c}\mathbf{P} \\
\text { Değeri }\end{array}$ & $\begin{array}{c}F \\
\text { Değeri }\end{array}$ & $\begin{array}{c}P \\
\text { Değeri }\end{array}$ \\
\hline \multirow{30}{*}{$\begin{array}{l}\text { Bilgilendiri } \\
\text { cilik }\end{array}$} & \multirow{5}{*}{$16-24$} & \multirow{5}{*}{3,1379} & $25-34$ & 0,08665 & 0,11129 & 0,988 & \multirow{30}{*}{3,684} & \multirow{30}{*}{0,003} \\
\hline & & & $35-44$ & $-0,02353$ & 0,13697 & 1 & & \\
\hline & & & $45-54$ & $-0,13107$ & 0,14173 & 0,973 & & \\
\hline & & & $55-64$ & $-0,56445$ & 0,18071 & 0,085 & & \\
\hline & & & $\begin{array}{l}65 \mathrm{Ve} \\
\text { Üzeri }\end{array}$ & $-0,52874$ & 0,30728 & 0,706 & & \\
\hline & \multirow{5}{*}{$25-34$} & \multirow{5}{*}{3,0513} & $16-24$ & $-0,08665$ & 0,11129 & 0,988 & & \\
\hline & & & $35-44$ & $-0,11018$ & 0,12346 & 0,977 & & \\
\hline & & & $45-54$ & $-0,21772$ & 0,12873 & 0,721 & & \\
\hline & & & $55-64$ &,$- 65110(*)$ & $\mathbf{0 , 1 7 0 7}$ & 0,014 & & \\
\hline & & & $\begin{array}{l}65 \mathrm{Ve} \\
\text { Üzeri }\end{array}$ & $-0,61538$ & 0,3015 & 0,527 & & \\
\hline & \multirow{5}{*}{$35-44$} & \multirow{5}{*}{3,1615} & $16-24$ & 0,02353 & 0,13697 & 1 & & \\
\hline & & & $25-34$ & 0,11018 & 0,12346 & 0,977 & & \\
\hline & & & $45-54$ & $-0,10755$ & 0,15147 & 0,992 & & \\
\hline & & & $55-64$ & $-0,54092$ & 0,18845 & 0,146 & & \\
\hline & & & $\begin{array}{l}65 \mathrm{Ve} \\
\text { Üzeri }\end{array}$ & $-0,50521$ & 0,31189 & 0,758 & & \\
\hline & \multirow{5}{*}{$45-54$} & \multirow{5}{*}{3,269} & $16-24$ & 0,13107 & 0,14173 & 0,973 & & \\
\hline & & & $25-34$ & 0,21772 & 0,12873 & 0,721 & & \\
\hline & & & $35-44$ & 0,10755 & 0,15147 & 0,992 & & \\
\hline & & & $55-64$ & $-0,43338$ & 0,19194 & 0,406 & & \\
\hline & & & $\begin{array}{l}65 \mathrm{Ve} \\
\text { Üzeri }\end{array}$ & $-0,39766$ & 0,31401 & 0,9 & & \\
\hline & \multirow{5}{*}{$55-64$} & \multirow{5}{*}{3,7024} & $16-24$ & 0,56445 & 0,18071 & 0,085 & & \\
\hline & & & $25-34$ &, $65110(*)$ & $\mathbf{0 , 1 7 0 7}$ & 0,014 & & \\
\hline & & & $35-44$ & 0,54092 & 0,18845 & 0,146 & & \\
\hline & & & $45-54$ & 0,43338 & 0,19194 & 0,406 & & \\
\hline & & & $\begin{array}{l}65 \mathrm{Ve} \\
\text { Üzeri }\end{array}$ & 0,03571 & 0,33343 & 1 & & \\
\hline & \multirow{5}{*}{$\begin{array}{c}65 \mathrm{VE} \\
\text { ÜZERİ }\end{array}$} & \multirow{5}{*}{3,6667} & $16-24$ & 0,52874 & 0,30728 & 0,706 & & \\
\hline & & & $25-34$ & 0,61538 & 0,3015 & 0,527 & & \\
\hline & & & $35-44$ & 0,50521 & 0,31189 & 0,758 & & \\
\hline & & & $45-54$ & 0,39766 & 0,31401 & 0,9 & & \\
\hline & & & $55-64$ & $-0,03571$ & 0,33343 & 1 & & \\
\hline
\end{tabular}


$\mathbf{H}_{\mathbf{0}}$ : Bilgilendiricilik açısından yaş grupları arasında anlamlı bir fark yoktur.

$\mathbf{H}_{6 \mathbf{C}}$ : Bilgilendiricilik açısından yaş grupları arasında anlamlı bir fark vardır.

BULGU: Yapılan analiz sonucunda infomercial reklama yönelik algıyı oluşturan alt boyutlardan biri olan bilgilendiricilik faktöründe yaş grupları arasında anlamlı bir farklılık olduğu belirlenmiş; infomercial reklamları 55-64 yaş grubunun, 25-34 yaş grubuna göre daha bilgilendirici bulduğu tespit edilmiştir. $(\mu$ 55-64 yaş $=3,70$ ve $\mu 25-34$ yaş $=3,05$ )

Levene testi sonuçlarına göre $p$ değeri $<0,05$ olan faktörler ile Welch ve Brown-Forsythe testleri yapılmıştır.

Aşağıdaki Tablo 33'de Tamhane $\mathrm{T}^{2}$ testine göre anlamlı bir farklılık görülen faktörlerin sonuçları yer alacaktır.

Tablo 35: Çeşitlilik ve Düşünmeden/Fevri Hareket Etme Faktörünün Yaş

Gruplarına Göre Dağılımı

WELCH VE BROWN-FORSYTHE testi sonucu

\begin{tabular}{|c|c|c|c|c|c|c|c|c|}
\hline & Yaş & $\mu$ & & $\begin{array}{c}\text { Ortalama } \\
\text { Farkı }\end{array}$ & $\begin{array}{c}\text { Standart } \\
\text { Hata }\end{array}$ & $\mathbf{P}$ & Welch & $\begin{array}{l}\text { Brown- } \\
\text { Forsythe }\end{array}$ \\
\hline \multirow{20}{*}{ Çeşitlilik } & \multirow{5}{*}{$16-24$} & \multirow{5}{*}{3,5441} & $25-34$ & 0,02910 & 0,09571 & 1,000 & \multirow{20}{*}{$\begin{array}{l}\mathbf{F}=3,708 \\
\mathbf{P}=0,006\end{array}$} & \multirow{20}{*}{$\begin{array}{l}\mathrm{F}=4,040 \\
\mathrm{P}=0,002\end{array}$} \\
\hline & & & $35-44$ & 0,38260 & 0,13227 & 0,067 & & \\
\hline & & & 45-54 & $0,45634(*)$ & 0,13839 & 0,020 & & \\
\hline & & & $\overline{55-64}$ & 0,22263 & 0,16026 & 0,941 & & \\
\hline & & & $\begin{array}{l}65 \mathrm{Ve} \\
\text { Üzeri }\end{array}$ & $-0,03927$ & 0,31545 & 1,000 & & \\
\hline & \multirow{5}{*}{$25-34$} & \multirow{5}{*}{3,5150} & $16-24$ & $-0,02910$ & 0,09571 & 1,000 & & \\
\hline & & & $35-44$ & 0,35350 & 0,12702 & 0,092 & & \\
\hline & & & $45-54$ & $0,42724(*)$ & 0,13338 & 0,028 & & \\
\hline & & & $55-64$ & 0,19353 & 0,15596 & 0,977 & & \\
\hline & & & $\begin{array}{l}65 \mathrm{Ve} \\
\text { Üzeri }\end{array}$ & $-0,06838$ & 0,31328 & 1,000 & & \\
\hline & \multirow{5}{*}{$35-44$} & \multirow{5}{*}{3,1615} & $16-24$ & $-0,38260$ & 0,13227 & 0,067 & & \\
\hline & & & $25-34$ & $-0,35350$ & 0,12702 & 0,092 & & \\
\hline & & & $45-54$ & 0,07374 & 0,16163 & 1,000 & & \\
\hline & & & $55-64$ & $-0,15997$ & 0,18072 & 0,999 & & \\
\hline & & & $\begin{array}{l}65 \mathrm{Ve} \\
\text { Üzeri }\end{array}$ & $-0,42187$ & 0,32631 & 0,980 & & \\
\hline & \multirow{5}{*}{$45-54$} & \multirow{5}{*}{3,0877} & $16-24$ & $-0,45634(*)$ & $\mathbf{0 , 1 3 8 3 9}$ & 0,020 & & \\
\hline & & & $25-34$ & $-0,42724(*)$ & 0,13338 & 0,028 & & \\
\hline & & & $35-44$ & $-0,07374$ & 0,16163 & 1,000 & & \\
\hline & & & $55-64$ & $-0,23371$ & 0,18524 & 0,972 & & \\
\hline & & & $\begin{array}{l}65 \mathrm{Ve} \\
\text { Üzeri }\end{array}$ & $-0,49561$ & 0,32884 & 0,934 & & \\
\hline
\end{tabular}




\begin{tabular}{|c|c|c|c|c|c|c|c|c|}
\hline & & & $16-24$ & $-0,22263$ & 0,16026 & 0,941 & & \\
\hline & & & $25-34$ & $-0,19353$ & 0,15596 & 0,977 & & \\
\hline & $55-64$ & 33214 & $35-44$ & 0,15997 & 0,18072 & 0,999 & & \\
\hline & כЈ-04 & $3,3<14$ & $45-54$ & 0,23371 & 0,18524 & 0,972 & & \\
\hline & & & $\begin{array}{l}65 \mathrm{Ve} \\
\text { Üzeri }\end{array}$ & $-0,26190$ & 0,33863 & 1,000 & & \\
\hline & & & $16-24$ & 0,03927 & 0,31545 & 1,000 & & \\
\hline & & & $25-34$ & 0,06838 & 0,31328 & 1,000 & & \\
\hline & OJ VE & 3,5833 & $35-44$ & 0,42187 & 0,32631 & 0,980 & & \\
\hline & & & $45-54$ & 0,49561 & 0,32884 & 0,934 & & \\
\hline & & & 55-64 & 0,26190 & 0,33863 & 1,000 & & \\
\hline & & & 25-34 & $0,25939(*)$ & $\mathbf{0 , 0 7 7 8 8}$ & 0,016 & & \\
\hline & & & $35-44$ & 0,28924 & 0,11062 & 0,141 & & \\
\hline & $16-24$ & 31408 & $45-54$ & 0,18905 & 0,09604 & 0,545 & & \\
\hline & $10-24$ & 3,1400 & 55-64 & 0,06045 & 0,09199 & 1,000 & & \\
\hline & & & $\begin{array}{l}65 \mathrm{Ve} \\
\text { Üzeri }\end{array}$ & $-0,04670$ & 0,16778 & 1,000 & & \\
\hline & & & 16-24 & $-0,25939(*)$ & $\mathbf{0 , 0 7 7 8 8}$ & 0,016 & & \\
\hline & & & $35-44$ & 0,02985 & 0,09996 & 1,000 & & \\
\hline & $25-34$ & 28814 & $45-54$ & $-0,07034$ & 0,08354 & 1,000 & & \\
\hline & $25-34$ & 2,0014 & 55-64 & $-0,19895$ & 0,07885 & 0,198 & & \\
\hline & & & $\begin{array}{l}65 \mathrm{Ve} \\
\text { Üzeri }\end{array}$ & $-0,30609$ & 0,16095 & 0,769 & & \\
\hline & & & 16-24 & $-0,28924$ & 0,11062 & 0,141 & & \\
\hline & & & $25-34$ & $-0,02985$ & 0,09996 & 1,000 & & \\
\hline & & & $45-54$ & $-0,10019$ & 0,11468 & 0,999 & & \\
\hline & $35-44$ & 2,8510 & 55-64 & $-0,22879$ & 0,11131 & 0,481 & & \\
\hline den/Fevri & & & $\begin{array}{l}65 \mathrm{Ve} \\
\text { Üzeri }\end{array}$ & $-0,33594$ & 0,17910 & 0,734 & $\mathbf{F}=3,376$ & $\mathrm{~F}=3,717$ \\
\hline $\begin{array}{c}\text { Hareket } \\
\text { Etme }\end{array}$ & & & 16-24 & $-0,18905$ & 0,09604 & 0,545 & & \\
\hline & & & $25-34$ & 0,07034 & 0,08354 & 1,000 & & \\
\hline & $45-54$ & 29518 & $35-44$ & 0,10019 & 0,11468 & 0,999 & & \\
\hline & $4 J-J 4$ & 2,9310 & 55-64 & $-0,12860$ & 0,09683 & 0,956 & & \\
\hline & & & $\begin{array}{l}65 \mathrm{Ve} \\
\text { Üzeri }\end{array}$ & $-0,23575$ & 0,17048 & 0,962 & & \\
\hline & & & 16-24 & $-0,06045$ & 0,09199 & 1,000 & & \\
\hline & & & $25-34$ & 0,19895 & 0,07885 & 0,198 & & \\
\hline & $55-64$ & 30804 & $35-44$ & 0,22879 & 0,11131 & 0,481 & & \\
\hline & JJ-04 & 3,0004 & $45-54$ & 0,12860 & 0,09683 & 0,956 & & \\
\hline & & & $\begin{array}{l}65 \mathrm{Ve} \\
\text { Üzeri }\end{array}$ & $-0,10714$ & 0,16824 & 1,000 & & \\
\hline & & & 16-24 & 0,04670 & 0,16778 & 1,000 & & \\
\hline & & & $25-34$ & 0,30609 & 0,16095 & 0,769 & & \\
\hline & $\begin{array}{l}\text { 0) VEE } \\
\text { ÜZERİ }\end{array}$ & 3,1875 & $35-44$ & 0,33594 & 0,17910 & 0,734 & & \\
\hline & & & $45-54$ & 0,23575 & 0,17048 & 0,962 & & \\
\hline & & & $55-64$ & 0,10714 & 0,16824 & 1,000 & & \\
\hline
\end{tabular}

$\mathbf{H}_{0}$ : Çeşitlilik açısından yaş grupları arasında anlamlı bir fark yoktur.

$\mathbf{H}_{14 \mathbf{C}}$ : Çeşitlilik açısından yaş grupları arasında anlamlı bir fark vardır. 

fark yoktur.

$\mathbf{H}_{0}$ : Düşüncesiz/fevri hareket etmek açısından yaş grupları arasında anlamlı bir

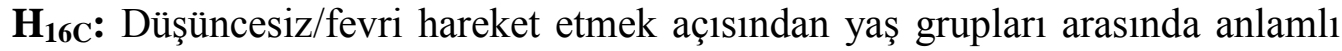
bir fark vardir.

$\boldsymbol{B U} \boldsymbol{L G U}$ : Yapılan analiz sonucunda, alıcının kişilik özelliklerinin alt boyutu olan "çeşitlilik" ve "düşüncesi z/fevri hareket etmek" faktörlerinde yaş grupları arasında anlamlı bir farklılık olduğu belirlenmiştir.

16-34 yaş arasındaki grubun 45-54 orta yaş grubuna göre daha fazla çeşitlilik aradığ1 görülmüştür. ( $\mu 16-24$ yaş $=3,54$ ve $\mu 45-54$ yaş $=3,08)$ ve $(\mu 25-34$ yaş $=3,51$ ve $\mu 45-54$ yaş $=3,08$ )

16-24 yaş arasındaki grubun 25-34 orta yaş grubuna göre daha düşüncesizce hareket ettiği görülmüştür. ( $\mu 16-24$ yaş=3,14 ve $\mu 25-34$ yaş $=2,88$ )

Haneye Giren Aylık Toplam Gelire Göre Farklılı̆̆ın Test Edilmesi: Gelir grupları (751 TL ve alt1),(751 TL-1500 TL), (1501 TL-2000 TL), (2001 TL-2500 TL), (2501 TL-3000 TL), (3001 TL-3500 TL), (3501 TL-4000 TL), (4001 TL-4500 TL), (4501 TL-5000 TL) ve (5001 TL ve üzeri) olmak üzere on tanedir. "Eğlendiricilik", "rahatsız edicilik", "aldatıcılık", "bilgilendiricilik", "çeşitlilik", "risk", “düşünmeden/ fevri hareket etme”, "fiyat bilinci”, "marka bilinci”, "satın almadan önceki ürün hakkındaki düşünce", "satın almadan önceki reklam hakkındaki düşünce”, “ödeme şekli ve hayatı kolaylaştırma", "reklam süresi”, “yorumlar/kanıtlar/karşılaştırma” faktörleri açısından bu gruplar arasında farklılığın bulunup bulunmadığını belirlemek amacıyla tek yönlü varyans analizi ANOVA testinden yararlanılmıştır. Test sonuçları ve hipotezler aşağıdaki gibidir. fark yoktur.

$\mathbf{H}_{\mathbf{0}}$ : Faktörler açısından haneye giren aylık toplam gelir arasında anlamlı bir

$\mathbf{H}_{1}$ : Faktörler açısından haneye giren aylık toplam gelir arasında anlamlı bir fark vardır.

Levene testi sonuçlarına göre $\mathrm{p}$ değeri $<0,05$ olan faktörler ile Welch ve Brown-Forsythe testleri yapılmış ve buna göre Tablo 34'de Tamhane $\mathrm{T}^{2}$ testine göre anlamlı bir farklılık görülen faktörlerin sonuçları yer almıştır. 
Tablo 36: Risk Faktörünün Haneye Giren Aylık Toplam Gelire Göre Dağılımı

WELCH VE BROWN-FORSYTHE testi sonucu

\begin{tabular}{|c|c|c|c|c|c|c|c|}
\hline Gelir & $\mu$ & & $\begin{array}{c}\text { Ortalama } \\
\text { Farkı }\end{array}$ & $\begin{array}{c}\text { Standart } \\
\text { Hata }\end{array}$ & $\mathbf{P}$ & Welch & $\begin{array}{l}\text { Brown- } \\
\text { Forsythe }\end{array}$ \\
\hline \multirow{9}{*}{$\begin{array}{c}750 \text { TL ve } \\
\text { Altı }\end{array}$} & \multirow{9}{*}{4,0513} & $751-1500 \mathrm{TL}$ &,- 15448 & ,28067 & 1,000 & \multirow{46}{*}{$\begin{array}{l}\mathbf{F}=5,189 \\
\mathbf{P}=0,000\end{array}$} & \multirow{46}{*}{$\begin{array}{l}\mathbf{F}=3,446 \\
\mathbf{P}=0,001\end{array}$} \\
\hline & & $1501-2000 \mathrm{TL}$ &,- 23678 & ,28190 & 1,000 & & \\
\hline & & $2001-2500 \mathrm{TL}$ &,- 24696 & ,27844 & 1,000 & & \\
\hline & & $2501-3000 \mathrm{TL}$ &,- 50110 & ,27811 & ,988 & & \\
\hline & & $3001-3500 \mathrm{TL}$ &,- 59455 & ,27716 & 900 & & \\
\hline & & $3501-4000 \mathrm{TL}$ &,- 64569 & ,27788 & ,804 & & \\
\hline & & $4001-4500 \mathrm{TL}$ &,- 52279 & ,28466 & ,982 & & \\
\hline & & $4501-5000 \mathrm{TL}$ &,- 24284 & ,31415 & 1,000 & & \\
\hline & & $5001 \mathrm{TL} /$ Üstü &,- 12296 & ,27737 & 1,000 & & \\
\hline \multirow{9}{*}{$\begin{array}{c}751-1500 \\
T L\end{array}$} & \multirow{9}{*}{4,2058} & 750 TL Ve Alt1 & , 15448 & ,28067 & 1,000 & & \\
\hline & & $1501-2000 \mathrm{TL}$ &,- 08230 &, 12740 & 1,000 & & \\
\hline & & $2001-2500 \mathrm{TL}$ &,- 09248 &, 11955 & 1,000 & & \\
\hline & & $2501-3000 \mathrm{TL}$ &,- 34662 & 11878 &, 177 & & \\
\hline & & 3001-3500 TL &,$- 44007(*)$ & ,11653 &, 012 & & \\
\hline & & $3501-4000$ TL &,$- 49121(*)$ &, 11823 &, 004 & & \\
\hline & & $4001-4500 \mathrm{TL}$ &,- 36831 &, 13340 & ,309 & & \\
\hline & & $4501-5000 \mathrm{TL}$ &,- 08836 & , 18829 & 1,000 & & \\
\hline & & $5001 \mathrm{TL} /$ Üstü & 03152 & 11705 & 1,000 & & \\
\hline \multirow{9}{*}{$\begin{array}{c}1501- \\
2000 T L\end{array}$} & \multirow{9}{*}{4,2881} & 750 TL Ve Alt1 & ,23678 & ,28190 & 1,000 & & \\
\hline & & $751-1500 \mathrm{TL}$ & 08230 & 12740 & 1,000 & & \\
\hline & & $2001-2500 \mathrm{TL}$ &,- 01018 & 12241 & 1,000 & & \\
\hline & & $2501-3000 \mathrm{TL}$ &,- 26432 &, 12166 &, 769 & & \\
\hline & & $3001-3500 \mathrm{TL}$ &,- 35777 & ,11947 &, 144 & & \\
\hline & & $3501-4000 \mathrm{TL}$ &,- 40890 &, 12113 &, 050 & & \\
\hline & & $4001-4500 \mathrm{TL}$ &,- 28601 &, 13597 &, 844 & & \\
\hline & & $4501-5000 \mathrm{TL}$ &,- 00605 & 19011 & 1,000 & & \\
\hline & & $5001 \mathrm{TL} /$ Üstü &, 11382 & ,11997 & 1,000 & & \\
\hline \multirow{9}{*}{$\begin{array}{c}2001- \\
2500 T L\end{array}$} & \multirow{9}{*}{4,2982} & 750 TL Ve Alt1 & ,24696 & ,27844 & 1,000 & & \\
\hline & & $751-1500 \mathrm{TL}$ &, 09248 &, 11955 & 1,000 & & \\
\hline & & $1501-2000 \mathrm{TL}$ &, 01018 &, 12241 & 1,000 & & \\
\hline & & $2501-3000 \mathrm{TL}$ &,- 25414 &, 11340 & ,717 & & \\
\hline & & $3001-3500 \mathrm{TL}$ &,- 34759 &, 11105 &, 103 & & \\
\hline & & $3501-4000 \mathrm{TL}$ &,$- 39872(*)$ &, 11283 &, 034 & & \\
\hline & & $4001-4500 \mathrm{TL}$ &,- 27583 &, 12864 &, 825 & & \\
\hline & & $4501-5000 \mathrm{TL}$ & 00413 &, 18494 & 1,000 & & \\
\hline & & 5001 TL/Üstü &, 12400 & , 11159 & 1,000 & & \\
\hline \multirow{9}{*}{$\begin{array}{c}2501-3000 \\
T L\end{array}$} & \multirow{9}{*}{4,5524} & 750 TL Ve Alt1 & ,50110 & ,27811 & ,988 & & \\
\hline & & $751-1500 \mathrm{TL}$ & ,34662 &, 11878 & 177 & & \\
\hline & & $1501-2000 \mathrm{TL}$ & ,26432 &, 12166 & ,769 & & \\
\hline & & $2001-2500 \mathrm{TL}$ & ,25414 &, 11340 &, 717 & & \\
\hline & & $3001-3500 \mathrm{TL}$ &,- 09345 &, 11022 & 1,000 & & \\
\hline & & $3501-4000 \mathrm{TL}$ &,- 14459 &, 11202 & 1,000 & & \\
\hline & & $4001-4500 \mathrm{TL}$ &,- 02169 & 12792 & 1,000 & & \\
\hline & & $4501-5000 \mathrm{TL}$ &, 25826 &, 18445 & 1,000 & & \\
\hline & & 5001 TL / /üstü & ,37814(*) & ,11076 & ,045 & & \\
\hline $3001-3500$ & 4,6458 & 750 TL Ve Alt1 &, 59455 & ,27716 & 900 & & \\
\hline
\end{tabular}




\begin{tabular}{|c|c|c|c|c|c|}
\hline \multirow[t]{8}{*}{$T L$} & & $751-1500 \mathrm{TL}$ & ,44007(*) & ,11653 & ,012 \\
\hline & & $1501-2000 \mathrm{TL}$ &, 35777 & , 11947 &, 144 \\
\hline & & $2001-2500 \mathrm{TL}$ & ,34759 & ,11105 & ,103 \\
\hline & & $2501-3000 \mathrm{TL}$ &, 09345 &, 11022 & 1,000 \\
\hline & & $3501-4000 \mathrm{TL}$ &,- 05114 & , 10963 & 1,000 \\
\hline & & $4001-4500 \mathrm{TL}$ &, 07176 & , 12584 & 1,000 \\
\hline & & $4501-5000 \mathrm{TL}$ & ,35172 & , 18301 & ,956 \\
\hline & & 5001 TL /Üstü & ,47159(*) & ,10835 & ,002 \\
\hline \multirow{9}{*}{$\begin{array}{c}3501-4000 \\
T L\end{array}$} & \multirow{9}{*}{4,6970} & 750 TL Ve Alt1 &, 64569 & ,27788 & ,804 \\
\hline & & $751-1500 \mathrm{TL}$ & ,49121(*) & ,11823 & ,004 \\
\hline & & $1501-2000 \mathrm{TL}$ &, 40890 & , 12113 &, 050 \\
\hline & & 2001-2500 TL & ,39872(*) &, 11283 &, 034 \\
\hline & & $2501-3000 \mathrm{TL}$ &, 14459 &, 11202 & 1,000 \\
\hline & & $3001-3500 \mathrm{TL}$ &, 05114 & , 10963 & 1,000 \\
\hline & & $4001-4500 \mathrm{TL}$ &, 12290 &, 12742 & 1,000 \\
\hline & & $4501-5000 \mathrm{TL}$ &, 40285 & , 18409 &, 833 \\
\hline & & 5001 TL /Üstü &, $52273(*)$ & ,11018 & ,001 \\
\hline \multirow{9}{*}{$\begin{array}{c}4001-4500 \\
T L\end{array}$} & \multirow{9}{*}{4,5741} & 750 TL Ve Alt1 &, 52279 & ,28466 & ,982 \\
\hline & & $751-1500 \mathrm{TL}$ & ,36831 &, 13340 & ,309 \\
\hline & & $1501-2000 \mathrm{TL}$ & ,28601 & , 13597 & ,844 \\
\hline & & $2001-2500 \mathrm{TL}$ & ,27583 &, 12864 &, 825 \\
\hline & & $2501-3000 \mathrm{TL}$ & ,02169 &, 12792 & 1,000 \\
\hline & & $3001-3500 \mathrm{TL}$ &,- 07176 &, 12584 & 1,000 \\
\hline & & $3501-4000 \mathrm{TL}$ &,- 12290 &, 12742 & 1,000 \\
\hline & & $4501-5000 \mathrm{TL}$ & ,27996 & , 19418 & 1,000 \\
\hline & & 5001 TL/Üstü & ,39983 & , 12632 & ,129 \\
\hline \multirow{9}{*}{$\begin{array}{c}4501-5000 \\
T L\end{array}$} & \multirow{9}{*}{4,2941} & 750 TL Ve Alt1 & ,24284 & ,31415 & 1,000 \\
\hline & & $751-1500 \mathrm{TL}$ & ,08836 & , 18829 & 1,000 \\
\hline & & $1501-2000 \mathrm{TL}$ & ,00605 & , 19011 & 1,000 \\
\hline & & $2001-2500 \mathrm{TL}$ &,- 00413 & , 18494 & 1,000 \\
\hline & & $2501-3000 \mathrm{TL}$ &,- 25826 &, 18445 & 1,000 \\
\hline & & $3001-3500 \mathrm{TL}$ &,- 35172 & , 18301 & ,956 \\
\hline & & $3501-4000 \mathrm{TL}$ &,- 40285 & , 18409 & ,833 \\
\hline & & $4001-4500 \mathrm{TL}$ &,- 27996 & , 19418 & 1,000 \\
\hline & & $5001 \mathrm{TL} /$ Üstü & ,11988 & , 18334 & 1,000 \\
\hline \multirow{9}{*}{$\begin{array}{c}5001 T L \\
V e \ddot{U} s t \ddot{u}\end{array}$} & \multirow{9}{*}{4,1742} & 750 TL Ve Alt1 & , 12296 & ,27737 & 1,000 \\
\hline & & $751-1500 \mathrm{TL}$ &,- 03152 & ,11705 & 1,000 \\
\hline & & $1501-2000 \mathrm{TL}$ &,- 11382 & ,11997 & 1,000 \\
\hline & & $2001-2500 \mathrm{TL}$ &,- 12400 & ,11159 & 1,000 \\
\hline & & 2501-3000 TL &,$- 37814(*)$ & ,11076 &, 045 \\
\hline & & 3001-3500 TL &,$- 47159(*)$ & ,10835 &, 002 \\
\hline & & 3501-4000 TL &,$- 52273(*)$ & ,11018 & ,001 \\
\hline & & $4001-4500 \mathrm{TL}$ &,- 39983 & ,12632 &, 129 \\
\hline & & $4501-5000 \mathrm{TL}$ &,- 11988 & ,18334 & 1,000 \\
\hline
\end{tabular}

$\mathbf{H}_{\mathbf{0}}$ : Risk açısından haneye giren aylık toplam gelir arasında anlamlı bir fark yoktur.

$\mathbf{H}_{15 F}$ : Risk açısından haneye giren aylık toplam gelir arasında anlamlı bir fark vardir. 
BULGU: Yapılan analiz sonucunda, alıcının kişilik özelliklerinin alt boyutu olan "risk" faktöründe haneye giren aylık toplam gelir arasında anlamlı bir farkl1lık olduğu belirlenmiş; hanesine ayda ortalama 3001-3500 TL giren grubun, hanesine ayda ortalama 751-1500 TL ve $5001 \mathrm{TL}$ ve üstü giren gelir gruplarına göre, [( $\mu 3001-3500$ $\mathrm{TL}=4,64$ ve $\mu$ 751-1500 TL=4,20) ve $(\mu 3001-3500 \mathrm{TL}=4,64$ ve $\mu 5001 \mathrm{TL}$ ve üstü=4,17)] hanesine ayda ortalama 3501-4000 TL giren grubun, hanesine ayda ortalama 751-1500 TL, 2001-2500 TL ve 5001 TL ve üstü giren gelir gruplarına göre, [ $(\mu 3501-4000=4,69$ ve $\mu 751-1500 \mathrm{TL}=4,20)$ ve $(\mu 3501-4000=4,69$ ve $\mu 2001-2500 \mathrm{TL}=4,29)$ ve $(\mu 3501-$ $4000=4,69$ ve $\mu 5001$ TL ve üstü=4,17)] ve hanesine ayda ortalama 2501-3000 TL giren grubun, hanesine ayda ortalama 5001 TL ve üstü giren gelir gruplarına göre $[(\mu 2501-3000 \mathrm{TL}=4,55$ ve $\mu 5001 \mathrm{TL}$ ve üstü=4,17)] riskli ürünler almaktan kaçındıkları görülmüştür.

Medeni Durum Açısından Farklılı̆̆ın Test Edilmesi: Medeni durum (evli),(boşanmış), (bekar) ve (dul) olmak üzere dört tanedir. "Eğlendiricilik”, "rahatsız edicilik", “aldatıcılık”, "bilgilendiricilik", “çeşitlilik”, “risk”, “düşünmeden/ fevri hareket etme”, "fiyat bilinci”, “marka bilinci”, “satın almadan önceki ürün hakkındaki düşünce", "satın almadan önceki reklam hakkındaki düşünce", "ödeme şekli ve hayatı kolaylaştırma", "reklam süresi”, "yorumlar/kanıtlar/karşılaştırma" faktörleri açısından bu gruplar arasında farklılığın bulunup bulunmadığını belirlemek amacıyla tek yönlü varyans analizi ANOVA test sonuçları ve hipotezler aşağıdaki gibidir.

$\mathbf{H}_{\mathbf{0}}$ : Faktörler açısından medeni durum arasında anlamlı bir fark yoktur.

$\mathbf{H}_{1}$ : Faktörler açısından medeni durum arasında anlamlı bir fark vardır.

Așağıdaki Tablo 37'de Scheffe testine göre anlamlı bir farklılık görülen faktörlerin sonuçları yer alacaktır. 
Tablo 37: Risk, Eğlendiricilik, Aldatıcılık, Bilgilendiricilik Faktörlerinin Medeni

Duruma Göre Dağılımı

ANOVA testi Sonucu

\begin{tabular}{|c|c|c|c|c|c|c|c|c|}
\hline & & $\mu$ & & $\begin{array}{c}\text { Ortalama } \\
\text { Farkı }\end{array}$ & $\begin{array}{c}\text { Standart } \\
\text { Hata }\end{array}$ & $\begin{array}{c}P \\
\text { Değeri }\end{array}$ & $\begin{array}{c}F \\
\text { Değeri }\end{array}$ & $\begin{array}{c}\mathbf{P} \\
\text { Değeri }\end{array}$ \\
\hline \multirow{12}{*}{ Risk } & \multirow{3}{*}{ Evli } & \multirow{3}{*}{4,3761} & Boşanmış &, $58124(*)$ & ,19521 &, 032 & \multirow{12}{*}{2,956} & \multirow{12}{*}{0,032} \\
\hline & & & Bekâr & ,03396 & ,07020 & ,972 & & \\
\hline & & & Dul &, 04278 & ,21116 & ,998 & & \\
\hline & \multirow{3}{*}{ Boşanmış } & \multirow{3}{*}{3,7949} & Evli &,$- 58124(*)$ & ,19521 &, 032 & & \\
\hline & & & Bekâr &,- 54728 & , 19515 &, 050 & & \\
\hline & & & Dul &,- 53846 & ,27882 & ,294 & & \\
\hline & \multirow{3}{*}{ Bekâr } & \multirow{3}{*}{4,3422} & Evli &,- 03396 & ,07020 & ,972 & & \\
\hline & & & Boşanmış & ,54728 & , 19515 & ,050 & & \\
\hline & & & Dul & ,00882 & ,21109 & 1,000 & & \\
\hline & \multirow{3}{*}{ Dul } & \multirow{3}{*}{4,3333} & Evli &,- 04278 & ,21116 & ,998 & & \\
\hline & & & Boşanmış & ,53846 & ,27882 & ,294 & & \\
\hline & & & Bekâr &,- 00882 & ,21109 & 1,000 & & \\
\hline \multirow{12}{*}{$\begin{array}{c}\text { Eğlendirici } \\
\quad \text { lik }\end{array}$} & \multirow{3}{*}{ Evli } & \multirow{3}{*}{2,7718} & Boşanmış & ,18209 & ,30085 & ,947 & \multirow{12}{*}{5,253} & \multirow{12}{*}{0,001} \\
\hline & & & Bekâr & ,21628 & , 10818 &, 263 & & \\
\hline & & & Dul &,$- 98574(*)$ &, 32542 & ,028 & & \\
\hline & \multirow{3}{*}{ Boşanmış } & \multirow{3}{*}{2,5897} & Evli &,- 18209 & ,30085 & ,947 & & \\
\hline & & & Bekâr &, 03419 & ,30074 & 1,000 & & \\
\hline & & & Dul & $-1,16783$ & ,42969 &, 062 & & \\
\hline & \multirow{3}{*}{ Bekâr } & \multirow{3}{*}{2,5556} & Evli &,- 21628 & , 10818 & ,263 & & \\
\hline & & & Boşanmış &,- 03419 & ,30074 & 1,000 & & \\
\hline & & & Dul & $-1,20202(*)$ &, 32532 &, 004 & & \\
\hline & \multirow{3}{*}{ Dul } & \multirow{3}{*}{3,7576} & Evli & ,98574(*) & ,32542 &, 028 & & \\
\hline & & & Boşanmış & 1,16783 & ,42969 & ,062 & & \\
\hline & & & Bekâr & $1,20202(*)$ &, 32532 & ,004 & & \\
\hline & & 30820 & Boşanmış &, 13328 & ,25759 & ,966 & & \\
\hline & Evli & 3,0820 & Bekâr &,- 18961 & ,09263 & ,243 & & \\
\hline & & & Dul & ,68806 & ,27863 & , 109 & & \\
\hline & & & Evli &,- 13328 & ,25759 & ,966 & & \\
\hline & Boşanmış & 2,9487 & Bekâr &,- 32289 & 25751 & ,666 & & \\
\hline & & & Dul & ,55478 & ,36792 & ,518 & & \\
\hline Aldatıcilık & & 3.2716 & Evli & , 18961 & ,09263 & ,243 & 4,328 & 0,005 \\
\hline & Bekâr & $3,2 / 10$ & Boşanmış &, 32289 & ,25751 & ,666 & & \\
\hline & & & Dul &, $87767(*)$ & ,27855 &, 020 & & \\
\hline & & & Evli &,- 68806 & ,27863 & , 109 & & \\
\hline & Dul & 2,3939 & Boşanmış &,- 55478 & ,36792 & ,518 & & \\
\hline & & & Bekâr &,$- 87767(*)$ & ,27855 & ,020 & & \\
\hline & & 3,1729 & Boşanmış &,- 13479 & ,23912 & 957 & & \\
\hline & Evli & & Bekâr & ,05474 & ,08599 & ,939 & & \\
\hline & & & Dul &,$- 91800(*)$ & ,25865 & ,006 & & \\
\hline Bilgilendiri & & & Evli &, 13479 & ,23912 & ,957 & 1828 & 0003 \\
\hline cilik & Boşanmış & $3,30 / 1$ & Bekâr & , 18953 & ,23904 & ,890 & $4,8<8$ & 0,003 \\
\hline & & & Dul &,- 78322 & ,34153 &, 156 & & \\
\hline & Rekâr & 31182 & Evli &,- 05474 & ,08599 & ,939 & & \\
\hline & Bekar & 3,1182 & Boşanmış &,- 18953 & ,23904 & ,890 & & \\
\hline
\end{tabular}




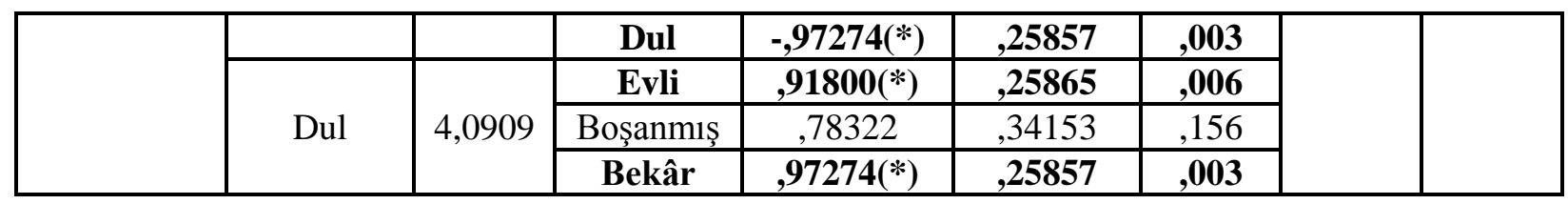

$\mathbf{H}_{\mathbf{0}}$ : Risk açısından medeni durum arasında anlamlı bir fark yoktur.

$\mathbf{H}_{15 \mathrm{~B}}$ : Risk açısından medeni durum arasında anlamlı bir fark vardır.

$\mathbf{H}_{\mathbf{0}}$ : Eğlendiricilik açısından medeni durum arasında anlamlı bir fark yoktur.

$\mathbf{H}_{7 \mathbf{B}}$ : Eğlendiricilik açısından medeni durum arasında anlamlı bir fark vardır.

$\mathbf{H}_{\mathbf{0}}$ : Aldatıcılık açısından medeni durum arasında anlamlı bir fark yoktur.

$\mathbf{H}_{\mathbf{8 B}}$ : Aldatıcılık açısından medeni durum arasında anlamlı bir fark vardır.

$\mathbf{H}_{\mathbf{0}}$ : Bilgilendiricilik açısından medeni durum arasında anlamlı bir fark yoktur.

$\mathbf{H}_{\mathbf{6 B}}$ Bilgilendiricilik açısından medeni durum arasında anlamlı bir fark vardır.

BULGU: Yapılan analiz sonucunda, alıcının kişilik özelliklerinin alt boyutu olan "risk" faktöründe ve infomercial reklama yönelik algının alt boyutu olan "eğlendiricilik", "aldatıcılık", "bilgilendiriclik" faktörlerinde medeni durum arasında anlamlı bir farklılık olduğu belirlenmiş; medeni durumu evli olanların, boşanmışlara göre riskli ürünler almaktan kaçındıkları belirlenmiştir. $(\mu$ evli=4,37 ve $\mu$ boşanmış= 3,79) Infomercial reklamları medeni durumu dul olan grubun evli ve bekâr olanlara göre daha

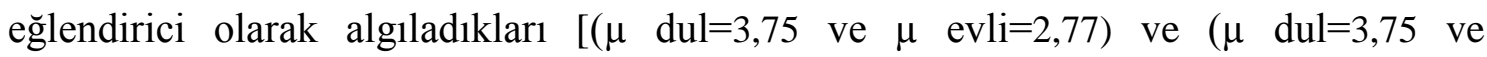
bekar=2,55)], medeni durumu bekar olan grubun dul olanlara göre daha aldatıcı olarak algıladıkları ( $\mu$ dul $=2,39$ ve $\mu$ bekar $=3,27)$ ve medeni durumu dul olanların evli ve bekar olanlara göre daha bilgilendirici olarak algıladıkları görülmüştür $[(\mu$ dul=4,09 ve $\mu$ evli $=3,17)$ ve $(\mu$ dul $=4,09$ ve $\mu$ bekar $=3,11)]$.

\section{Haftalık Televizyon İzleme Alışkanlıklarına Açısından Farklılı̆̆ın Test}

Edilmesi: Haftalık televizyon izleme alışkanlıkları (sadece hafta sonu), (hafta içi her gün), (hafta içi bazı günler) (hafta içi ve hafta sonu genellikle izlerim) olmak üzere dört tanedir. "Eğlendiricilik", "rahatsız edicilik", “aldatıcılık", "bilgilendiricilik”, “çeşitlilik", "risk", “düşünmeden/ fevri hareket etme”, “fiyat bilinci”, “marka bilinci”, "satın almadan önceki ürün hakkındaki düşünce", "satın almadan önceki reklam hakkındaki düşünce”, “ödeme şekli ve hayatı kolaylaştırma”, “reklam süresi”, “yorumlar/kanıtlar/karşılaştırma" faktörleri açısından bu gruplar arasında farklılığın 
bulunup bulunmadığını belirlemek amacıyla tek yönlü varyans analizi ANOVA test sonuçları ve hipotezler aşağıdaki gibidir.

$\mathbf{H}_{\mathbf{0}}$ : Faktörler açısından haftalık tv izleme arasında anlamlı bir fark yoktur.

$\mathbf{H}_{1}$ : Faktörler açısından haftalık tv izleme arasında anlamlı bir fark vardır.

Aşağıdaki Tablo 38'de Scheffe testine göre anlamlı bir farklılık görülen faktörlerin sonuçları yer alacaktır.

Tablo 38: Eğlendiricilik, Bilgilendiricilik, Marka Bilinci, Ödeme Koşulları ve Satın Almadan Önceki Reklam Hk. Düşünce Faktörlerinin Haftalık Televizyon İzleme

\section{Alışkanlıklarına Göre Dağılımı}

ANOVA testi Sonucu

\begin{tabular}{|c|c|c|c|c|c|c|c|c|}
\hline & & $\mu$ & & $\begin{array}{c}\text { Ortalama } \\
\text { Farkı }\end{array}$ & $\begin{array}{c}\text { Standart } \\
\text { Hata }\end{array}$ & $\begin{array}{c}\mathbf{P} \\
\text { Değeri }\end{array}$ & $\begin{array}{c}\mathbf{F} \\
\text { Değeri }\end{array}$ & $\begin{array}{c}\mathbf{P} \\
\text { Değeri }\end{array}$ \\
\hline \multirow{12}{*}{$\begin{array}{c}\text { Ĕ̆lendirici } \\
\quad \text { lik }\end{array}$} & \multirow{3}{*}{$\begin{array}{c}\text { Sadece } \\
\text { Hafta S. }\end{array}$} & \multirow{3}{*}{2,3951} & H.İçi &,- 56985 & ,23639 &, 123 & \multirow{12}{*}{3,639} & \multirow{12}{*}{0,013} \\
\hline & & & H.İçi Bazen &,- 11643 & ,22545 & ,966 & & \\
\hline & & & H.İçi/Sonu &,- 33974 & ,21767 & , 488 & & \\
\hline & \multirow{3}{*}{$\begin{array}{l}\text { Haftaiçi } \\
\text { Her Gün }\end{array}$} & \multirow{3}{*}{$\mathbf{2 , 9 6 4 9}$} & H.Sonu & ,56985 & ,23639 &, 123 & & \\
\hline & & & $\begin{array}{c}\text { H.İçi } \\
\text { Bazen }\end{array}$ &, $45342(*)$ & 15571 & ,038 & & \\
\hline & & & H.İçi/Sonu & ,23011 &, 14422 & ,468 & & \\
\hline & \multirow{3}{*}{$\begin{array}{c}\text { Hafta İçi } \\
\text { Bazen }\end{array}$} & \multirow{3}{*}{$\mathbf{2 , 5 1 1 5}$} & H.Sonu &, 11643 & ,22545 & ,966 & & \\
\hline & & & H.İçi &,$- 45342(*)$ & ,15571 &, 038 & & \\
\hline & & & H.İçi/Sonu &,- 22331 & ,12549 & ,368 & & \\
\hline & \multirow{3}{*}{$\begin{array}{c}\text { Haftaiçi/ } \\
\text { Hafta } \\
\text { Sonu }\end{array}$} & \multirow{3}{*}{2,7348} & H.Sonu & ,33974 & ,21767 & ,488 & & \\
\hline & & & H.İçi &,- 23011 &, 14422 & ,468 & & \\
\hline & & & H.İçi Bazen & ,22331 & 12549 & ,368 & & \\
\hline \multirow{12}{*}{$\begin{array}{l}\text { Bilgilendiri } \\
\quad \text { cilik }\end{array}$} & \multirow{3}{*}{$\begin{array}{r}\text { Sadece } \\
\text { Hafta S. }\end{array}$} & \multirow{3}{*}{$\mathbf{2 , 7 7 7 8}$} & H.İçi &,$- 62135(*)$ & ,18720 &, 012 & \multirow{12}{*}{4,216} & \multirow{12}{*}{0,006} \\
\hline & & & H.İçi Bazen &,- 31992 & 17854 & 362 & & \\
\hline & & & H.İçi/Sonu &,- 41559 &, 17238 &, 123 & & \\
\hline & \multirow{3}{*}{$\begin{array}{l}\text { Haftaiçi } \\
\text { Her Gün }\end{array}$} & \multirow{3}{*}{$\mathbf{3 , 3 9 9 1}$} & H.Sonu & ,62135(*) & ,18720 &, 012 & & \\
\hline & & & H.İçi Bazen &, 30142 & 12331 &, 115 & & \\
\hline & & & H.İçi/Sonu & ,20575 &, 11421 & 357 & & \\
\hline & \multirow{3}{*}{$\begin{array}{c}\text { Hafta İçi } \\
\text { Bazen }\end{array}$} & \multirow{3}{*}{3,0977} & H.Sonu & ,31992 & ,17854 & ,362 & & \\
\hline & & & H.İçi &,- 30142 & ,12331 &, 115 & & \\
\hline & & & H.İçi/Sonu &,- 09567 & ,09938 & 819 & & \\
\hline & \multirow{3}{*}{$\begin{array}{c}\text { Haftaiçi/ } \\
\text { Hafta } \\
\text { Sonu }\end{array}$} & \multirow{3}{*}{3,1934} & H.Sonu & ,41559 &, 17238 &, 123 & & \\
\hline & & & H.İçi &,- 20575 & ,11421 & ,357 & & \\
\hline & & & H.İçi Bazen & ,09567 & ,09938 & ,819 & & \\
\hline \multirow{5}{*}{$\begin{array}{l}\text { Marka } \\
\text { Bilinci }\end{array}$} & \multirow{3}{*}{$\begin{array}{r}\text { Sadece } \\
\text { Hafta S. }\end{array}$} & \multirow{3}{*}{$\mathbf{2 , 8 7 0 4}$} & H.İçi & ,47563 & , 18310 &, 082 & \multirow{5}{*}{3,001} & \multirow{5}{*}{0,030} \\
\hline & & & $\begin{array}{c}\text { H.İçi } \\
\text { Bazen }\end{array}$ &, $51692(*)$ & ,17463 & ,034 & & \\
\hline & & & H.İçi/Sonu & ,43391 & , 16860 & ,087 & & \\
\hline & \multirow{2}{*}{$\begin{array}{l}\text { Haftaiçi } \\
\text { Her Gün }\end{array}$} & \multirow{2}{*}{2,3947} & H.Sonu &,- 47563 &, 18310 &, 082 & & \\
\hline & & & H.İçi Bazen & ,04129 & , 12061 & ,990 & & \\
\hline
\end{tabular}




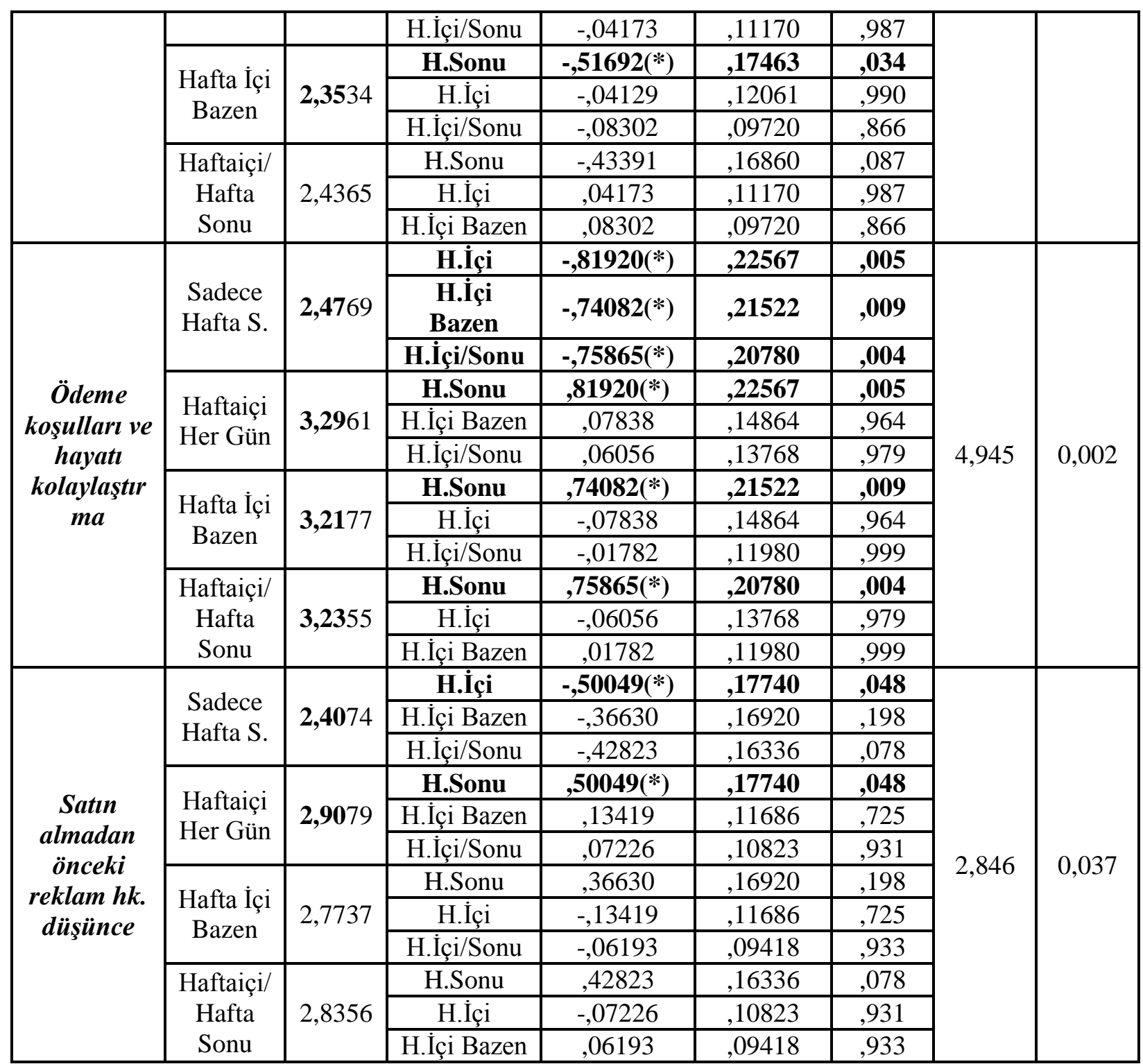

$\mathbf{H}_{\mathbf{0}}$ : Eğlendiricilik açısından haftalık tv izleme arasında anlamlı bir fark yoktur.

$\mathbf{H}_{7 \mathbf{j}}$ : Eğlendiricilik açısından haftalık tv izleme arasında anlamlı bir fark vardır.

$\mathbf{H}_{\mathbf{0}}$ : Bilgilendiricilik açısından haftalık tv izleme arasında anlamlı bir fark yoktur.

$\mathbf{H}_{6 \mathbf{6 j}}$ : Bilgilendiricilik açısından haftalık tv izleme arasında anlamlı bir fark vardir.

$\mathbf{H}_{\mathbf{0}}$ : Marka bilinci açısından haftalık tv izleme arasında anlamlı bir fark yoktur.

$\mathbf{H}_{23 \mathbf{j}}$ : Marka bilinci açısından haftalık tv izleme arasında anlamlı bir fark vardır.

$\mathbf{H}_{0}$ : Ödeme koşulları açısından haftalık tv izleme arasında anlamlı bir fark yoktur. 
$\mathbf{H}_{29 \mathbf{j}}$ : Ödeme koşulları/hayatı kolaylaştırma açısından haftalık tv izleme arasında anlamlı bir fark vardır.

$\mathbf{H}_{\mathbf{0}}$ : Satın almadan önceki reklam hakkındaki düşünce açısından haftalık tv izleme arasında anlamlı bir fark yoktur.

$\mathbf{H}_{32 \mathbf{j}}$ : Satın almadan önceki reklam hakkındaki düşünce açısından haftalık tv izleme arasında anlamlı bir fark vardır.

BULGU: Yapılan analiz sonucunda, infomercial reklama yönelik alg1 ölçeğinin alt boyutu olan "eğlendiricilik" ve "bilgilendiricilik" faktörlerinde, alıcının kişilik özellikleri ölçeğinin alt boyutu olan "marka bilinci” faktöründe ve reklam içeriği alt boyutu olan "ödeme" ve "satın alma öncesinde reklam hakkındaki düşünce" faktörlerinde haftalık tv izleme alışkanlıkları açısından anlamlı bir farklılık olduğu belirlenmiştir. Televizyonu hafta içi her gün izleyenlerin, hafta içi bazı günlerde izleyenlere göre infomercial reklamları daha eğlendirici ( $\mu$ hafta içi her gün=2,96 ve $\mu$ hafta içi bazı günler=2,51) ve hafta içi her gün izleyenlerin, sadece hafta sonunda izleyenlere göre bilgilendirici olarak algıladıkları görülmektedir ( $\mu$ hafta içi her gün=3,39 ve $\mu$ sadece hafta sonu=2,77). Televizyonu sadece hafta sonu izleyenlerin, hafta içi bazı günlerde izleyenlere göre daha fazla marka bilincine sahip oldukları anlaşılmıştır ( $\mu$ sadece hafta sonu=2,87 ve $\mu$ hafta içi bazı günler=2,35). Ayrıca hafta içi her gün, hafta içi bazı günler ve hafta içi ve hafta sonu genellikle izleyenlerin, sadece hafta sonunda izleyenlere göre infomercial reklamdaki ödeme koşullarından daha fazla etkilendikleri $[(\mu$ hafta içi her gün=3,29 ve $\mu$ hafta sonu=2,47) ve ( $\mu$ hafta içi bazen=3,21 ve $\mu$ sadece hafta sonu $=2,47)$ ve $(\mu$ hafta içi ve hafta sonu genellikle $=3,23$ ve $\mu$ sadece hafta sonu=2,47)] ve hafta içi her gün izleyenlerin sadece hafta sonu izleyenlere göre satın almadan önce reklam hakkındaki düşünceye sahip oldukları görülmektedir( $\mu$ hafta içi her gün=2,90 ve $\mu$ sadece hafta sonu=2,40) .

\section{Saatlik Televizyon İzleme Alışkanlıkları Açısından Farklılı̆̆ın Test Edilmesi:}

Saatlik televizyon izleme alışkanlıkları (06.00-10.00), (10.01-12.00), (12.01-19.00), (19.01-20.00) ve (20.01-23.00) olmak üzere beş tanedir. "Eğlendiricilik", "rahatsız edicilik", "aldatıcılık", "bilgilendiricilik", “çeşitlilik", "risk", “düşünmeden/ fevri hareket etme", "fiyat bilinci”, "marka bilinci”, "satın almadan önceki ürün hakkındaki düşünce", "satın almadan önceki reklam hakkındaki düşünce”, "ödeme şekli ve hayatı kolaylaştırma", "reklam süresi”, "yorumlar/kanıtlar/karşılaştırma" faktörleri açısından 
bu gruplar arasında farklılığın bulunup bulunmadığını belirlemek amacıyla tek yönlü varyans analizi ANOVA test sonuçları ve hipotezler aşağıdaki gibidir.

$\mathbf{H}_{\mathbf{0}}$ : Faktörler açısından saatlik tv izleme arasında anlamlı bir fark yoktur.

$\mathbf{H}_{1}$ : Faktörler açısından saatlik tv izleme arasında anlamlı bir fark vardır.

Aşağıdaki Tablo 34'de Scheffe testine göre anlamlı bir farklılık görülen faktörlerin sonuçları yer alacaktır.

Tablo 39: Düşüncesizce/fevri Alışveriş, Yorum ve Satın Almadan Önceki Reklam Hk. Düşünce Faktörlerinin Saatlik Televizyon İzleme Alışkanlıklarına Göre Dağılımı ANOVA testi Sonucu

\begin{tabular}{|c|c|c|c|c|c|c|c|c|}
\hline & & $\mu$ & & $\begin{array}{c}\text { Ortalama } \\
\text { Farkı }\end{array}$ & $\begin{array}{c}\text { Standart } \\
\text { Hata }\end{array}$ & $\begin{array}{c}\mathbf{P} \\
\text { Değeri }\end{array}$ & $\begin{array}{c}F \\
\text { Değeri }\end{array}$ & $\begin{array}{c}\mathbf{P} \\
\text { Değeri }\end{array}$ \\
\hline \multirow{20}{*}{ Düşüncesiz } & \multirow{4}{*}{$\begin{array}{c}06.00- \\
10.00\end{array}$} & \multirow{4}{*}{3,3700} & $10.01-12.00$ & ,41808 &, 16048 &, 150 & \multirow{20}{*}{4,853} & \multirow{20}{*}{0,001} \\
\hline & & & $12.01-19.00$ & ,39027 & , 14832 &, 142 & & \\
\hline & & & $19.01-20.00$ &, 30421 & ,13209 & ,260 & & \\
\hline & & & 20.01-23.00 & ,48441(*) & ,12050 &, 003 & & \\
\hline & \multirow{4}{*}{$\begin{array}{l}10.01- \\
12.00\end{array}$} & \multirow{4}{*}{2,9519} & $06.00-10.00$ &,- 41808 & , 16048 &, 150 & & \\
\hline & & & $12.01-19.00$ &,- 02781 & , 14661 & 1,000 & & \\
\hline & & & $19.01-20.00$ &,- 11387 & ,13016 & ,943 & & \\
\hline & & & $20.01-23.00$ &, 06633 & ,11838 & ,989 & & \\
\hline & \multirow{4}{*}{$\begin{array}{c}12.01- \\
19.00\end{array}$} & \multirow{4}{*}{2,9797} & $06.00-10.00$ &,- 39027 & , 14832 &, 142 & & \\
\hline & & & $10.01-12.00$ & ,02781 & , 14661 & 1,000 & & \\
\hline & & & $19.01-20.00$ &,- 08606 & ,11485 & 967 & & \\
\hline & & & $20.01-23.00$ & ,09414 & , 10130 & ,930 & & \\
\hline & \multirow{4}{*}{$\begin{array}{l}19.01- \\
20.00\end{array}$} & \multirow{4}{*}{3,0658} & $06.00-10.00$ &,- 30421 & ,13209 & 260 & & \\
\hline & & & $10.01-12.00$ &, 11387 & ,13016 & ,943 & & \\
\hline & & & $12.01-19.00$ & ,08606 & ,11485 & ,967 & & \\
\hline & & & $20.01-23.00$ & , 18020 & ,07556 & ,226 & & \\
\hline & \multirow{4}{*}{$\begin{array}{l}20.01- \\
23.00\end{array}$} & \multirow{4}{*}{2,8856} & 06.00-10.00 &,$- 48441(*)$ & ,12050 &, 003 & & \\
\hline & & & $10.01-12.00$ &,- 06633 & ,11838 & ,989 & & \\
\hline & & & $12.01-19.00$ &,- 09414 & , 10130 & ,930 & & \\
\hline & & & $19.01-20.00$ &,- 18020 & ,07556 & ,226 & & \\
\hline \multirow{13}{*}{ Yorum } & \multirow{4}{*}{$\begin{array}{c}06.00- \\
10.00\end{array}$} & \multirow{4}{*}{3,3829} & $10.01-12.00$ & ,24000 & ,26140 & ,932 & \multirow{13}{*}{5,307} & \multirow{13}{*}{0,000} \\
\hline & & & $12.01-19.00$ &, 57591 & ,24160 &, 226 & & \\
\hline & & & 19.01-20.00 &, $67233(*)$ & ,21516 & ,046 & & \\
\hline & & & 20.01-23.00 & ,76845(*) & ,19628 & ,005 & & \\
\hline & \multirow{4}{*}{$\begin{array}{c}10.01- \\
12.00\end{array}$} & \multirow{4}{*}{3,1429} & $06.00-10.00$ &,- 24000 & ,26140 & ,932 & & \\
\hline & & & $12.01-19.00$ & ,33591 & ,23881 & ,740 & & \\
\hline & & & $19.01-20.00$ & ,43233 & ,21202 & ,387 & & \\
\hline & & & $20.01-23.00$ & ,52845 & ,19283 &, 114 & & \\
\hline & \multirow{4}{*}{$\begin{array}{c}12.01- \\
19.00\end{array}$} & \multirow{4}{*}{2,8069} & $06.00-10.00$ &,- 57591 & ,24160 & ,226 & & \\
\hline & & & $10.01-12.00$ &,- 33591 & ,23881 &, 740 & & \\
\hline & & & $19.01-20.00$ &, 09642 & , 18707 & ,992 & & \\
\hline & & & $20.01-23.00$ &, 19254 & , 16501 & ,851 & & \\
\hline & 19.01- & 2,7105 & 06.00-10.00 &,$- 67233(*)$ & ,21516 & ,046 & & \\
\hline
\end{tabular}




\begin{tabular}{|c|c|c|c|c|c|c|c|c|}
\hline & \multirow[t]{3}{*}{20.00} & & $10.01-12.00$ &,- 43233 & ,21202 & ,387 & & \\
\hline & & & $12.01-19.00$ &,- 09642 &, 18707 & ,992 & & \\
\hline & & & $20.01-23.00$ & ,09612 & ,12308 & 962 & & \\
\hline & \multirow{4}{*}{$\begin{array}{l}20.01- \\
23.00\end{array}$} & \multirow{4}{*}{2,6144} & 06.00-10.00 &,$- 76845(*)$ & ,19628 & ,005 & & \\
\hline & & & $10.01-12.00$ &,- 52845 & ,19283 &, 114 & & \\
\hline & & & $12.01-19.00$ &,- 19254 &, 16501 & 851 & & \\
\hline & & & $19.01-20.00$ &,- 09612 & ,12308 & ,962 & & \\
\hline \multirow{20}{*}{$\begin{array}{c}\text { Satın } \\
\text { Almadan } \\
\text { Önce } \\
\text { Reklam hk. } \\
\text { Düşünce }\end{array}$} & \multirow{4}{*}{$\begin{array}{c}06.00- \\
10.00\end{array}$} & \multirow{4}{*}{3,4300} & $10.01-12.00$ & ,36269 & ,21672 & ,592 & \multirow{20}{*}{7,182} & \multirow{20}{*}{0,000} \\
\hline & & & $12.01-19.00$ & ,54486 & ,20031 &, 119 & & \\
\hline & & & $19.01-20.00$ &, 53197 &, 17838 &, 066 & & \\
\hline & & & 20.01-23.00 & ,76686(*) &, 16273 &, 000 & & \\
\hline & \multirow{4}{*}{$\begin{array}{c}10.01- \\
12.00\end{array}$} & \multirow{4}{*}{3,0673} & $06.00-10.00$ &,- 36269 & ,21672 & ,592 & & \\
\hline & & & $12.01-19.00$ & , 18217 & , 19800 & ,932 & & \\
\hline & & & $19.01-20.00$ & , 16928 &, 17578 & ,920 & & \\
\hline & & & $20.01-23.00$ & ,40417 & ,15987 &, 174 & & \\
\hline & \multirow{4}{*}{$\begin{array}{c}12.01- \\
19.00\end{array}$} & \multirow{4}{*}{2,8851} & $06.00-10.00$ &,- 54486 & 20031 &, 119 & & \\
\hline & & & $10.01-12.00$ &,- 18217 & , 19800 & ,932 & & \\
\hline & & & $19.01-20.00$ &,- 01289 &, 15510 & 1,000 & & \\
\hline & & & $20.01-23.00$ & ,22200 &, 13680 & ,621 & & \\
\hline & \multirow{4}{*}{$\begin{array}{l}19.01- \\
20.00\end{array}$} & \multirow{4}{*}{2,8980} & $06.00-10.00$ &,- 53197 &, 17838 & ,066 & & \\
\hline & & & $10.01-12.00$ &,- 16928 & , 17578 & ,920 & & \\
\hline & & & $12.01-19.00$ & ,01289 &, 15510 & 1,000 & & \\
\hline & & & $20.01-23.00$ & ,23489 &, 10204 & ,260 & & \\
\hline & \multirow{4}{*}{$\begin{array}{c}20.01- \\
23.00\end{array}$} & \multirow{4}{*}{2,6631} & 06.00-10.00 &,$- 76686(*)$ &, 16273 &, 000 & & \\
\hline & & & $10.01-12.00$ &,- 40417 &, 15987 &, 174 & & \\
\hline & & & $12.01-19.00$ &,- 22200 &, 13680 & ,621 & & \\
\hline & & & $19.01-20.00$ &,- 23489 & ,10204 & ,260 & & \\
\hline
\end{tabular}

$\mathbf{H}_{\mathbf{0}}$ : Düşüncesizce/fevri alışveriş etme faktörü ile saatlik tv izleme arasında anlamlı bir fark yoktur.

$\mathbf{H}_{21 I}$ : Düşüncesizce/fevri alışveriş etme faktörü ile saatlik tv izleme arasında anlamlı bir fark vardır.

$\mathbf{H}_{\mathbf{0}}$ : Yorumlar, kanıtlar ve karşılaştırma faktörü ile saatlik tv izleme arasında anlamlı bir fark yoktur.

$\mathbf{H}_{301}$ : Yorumlar, kanıtlar ve karşılaştırma faktörü ile saatlik tv izleme arasında anlamlı bir fark vardır.

$\mathbf{H}_{\mathbf{0}}$ : Satın almadan önceki reklam hk. düşünce faktörü ile saatlik tv izleme arasinda anlamlı bir fark yoktur.

$\mathbf{H}_{\text {32I }}$ : Satın almadan önceki reklam hk. düşünce faktörü ile saatlik tv izleme arasında anlamlı bir fark vardır.

YORUM: Yapılan analiz sonucunda alıcının kişilik özellikleri ölçeğinin alt boyutu olan "düşüncesizce/fevri hareket etme" faktöründe, infomercial reklam içeriği 
ölçeğinin alt boyutu olan "yorumlar/kanıtlar/karşılaştırma" ve "satın almadan önceki reklam hakkındaki düşünce" faktörlerinde saatlik televizyon izleme alışkanlıkları açısından anlamlı bir fark olduğu belirlenmiştir. Televizyonu "06.00-10.00" saatleri arasında izleyenlerin "20.01-23.00" saatleri arasında izleyenlere göre daha düşüncesizce/fevri hareket etme özelliğine sahip oldukları görülmektedir ( $\mu$ 06.00-10.00 saatleri=3,37 ve $\mu$ 20.01-23.00 saatleri=2,88). Ayrica televizyonu "06.00-10.00" saatleri arasında izleyenlerin “19.01-23.00” saatleri arasında izleyenlere göre infomercial reklam içeriğindeki yorum/kanıt veya karşılaştırmalardan daha fazla etkilendikleri görülmektedir $[(\mu 06.00-10.00$ saatleri=3,38 ve $\mu 19.01-20.00$ saatleri=2,71) ve $(\mu$ 06.0010.00 saatleri=3,38 ve $\mu$ 20.01-23.00 saatleri=2,61)]. Yine "06.00-10.00" saatleri arasında izleyenlerin “20.01-23.00” saatleri arasında izleyenlere göre satın almadan önceki reklam hakkındaki düşünceye sahip oldukları görülmektedir ( $\mu$ 06.00-10.00 saatleri $=3,43$ ve $\mu$ 20.01-23.00 saatleri=2,66).

\subsubsection{Infomercial Reklamlardan Şimdiye Kadar Ürün Satın Alanlar ile Almayanların Karşılaştırılması}

Anket sorularından ilki olan "Geleneksel kuşak reklamlarından uzun süren, ürünün özelliklerinin ve kullanım şekillerinin bir sunucu veya halktan ürünü deneyen kişi tarafından anlatılan (Kosmodisk Classic omurga masörü, Dr. Levine manyetik dizlik, H2O Buharlı temizleyici gibi) tanıtıcı (infomercial) reklamları izledikten sonra televizyon da verilen numarayı arayarak hiç alışveriş yaptınız mı?” sorusuna anketi cevaplayanların 100'ü evet yaptım yanıtını verirken 300'ü hayır yapmadım yanıtını vermişlerdir. $\mathrm{Bu}$ bağlamda şimdiye kadar satın alanlar ile almayanlar arasındaki farklılık demografik özellikler ve faktörler açısından analiz edilmiştir. Demografik özellikler açısından bir farklılık bulunmazken, faktörler açısından farklılıklar Tablo 40 de gösterilmektedir. 
Tablo 40: Infomercial Reklamlardan Şimdiye Kadar Satın Alanlar ile Almayanların Gelecekte Satın Alma Niyeti Yönünden Karşılaştırılması

\begin{tabular}{|c|c|c|c|c|c|c|c|}
\hline Faktör & & $\mathbf{N}$ & Ort. & S.S. & Levene & T testi & $P$ değeri \\
\hline \multirow{2}{*}{$\begin{array}{l}\text { Infomercial reklamlardan } \\
\text { gelecekte satın alma niyeti }\end{array}$} & Hayır & 300 & 2,3713 & 91927 & \multirow{2}{*}{,358 } & $-4,444$ & \multirow{2}{*}{$\begin{array}{l}, \mathbf{0 0 0} \\
, 000\end{array}$} \\
\hline & Evet & 100 & 2,8380 & ,87925 & & $-4,544$ & \\
\hline \multicolumn{8}{|l|}{ Soru ifadeleri } \\
\hline \multirow{2}{*}{$\begin{array}{l}\text { Tanıtıcı (infomercial) reklamlardan } \\
\text { önümüzdeki bir hafta içerisinde } \\
\text { tekrar satın almayı düşünüyorum. }\end{array}$} & Hayır & 300 & 2,13 & ,978 & \multirow{2}{*}{,131 } & $-2,362$ & \multirow{2}{*}{$\begin{array}{l}, 019 \\
, 022\end{array}$} \\
\hline & Evet & 100 & 2,40 & 1,025 & & $-2,307$ & \\
\hline \multirow{2}{*}{$\begin{array}{l}\text { Tanıtıcı (infomercial) reklamlardan } \\
\text { önümüzdeki bir ay içerisinde tekrar } \\
\text { satın almayı düşünüyorum. }\end{array}$} & Hayır & 300 & 2,16 & ,997 & \multirow{2}{*}{,007 } & $-2,902$ & \multirow{2}{*}{$\begin{array}{l}, 004 \\
, 007\end{array}$} \\
\hline & Evet & 100 & 2,51 & 1,141 & & $-2,712$ & \\
\hline \multirow{2}{*}{$\begin{array}{l}\text { Tanıtıcı (infomercial) reklamlardan } \\
\text { önümüzdeki bir yıl içerisinde tekrar } \\
\text { satın almayı düşünüyorum. }\end{array}$} & Hayır & 300 & 2,32 & 1,016 & \multirow{2}{*}{, 591} & $-4,861$ & \multirow{2}{*}{$\begin{array}{l}, 000 \\
, 000\end{array}$} \\
\hline & Evet & 100 & 2,90 & 1,106 & & $-4,661$ & \\
\hline \multirow{2}{*}{$\begin{array}{l}\text { Tanıtıcı (infomercial) reklamlardan } \\
\text { satın aldığım ürünü arkadaşlarıma } \\
\text { tavsiye etmeyi düşünüyorum. }\end{array}$} & Hayır & 300 & 2,62 & 1,146 & \multirow{2}{*}{,077 } & $-4,089$ & \multirow{2}{*}{$\begin{array}{l}, 000 \\
, 000\end{array}$} \\
\hline & Evet & 100 & 3,15 & 1,048 & & $-4,276$ & \\
\hline \multirow{2}{*}{$\begin{array}{l}\text { Tanıtıcı (infomercial) reklamlardan } \\
\text { satın aldığım ürünü aileme tavsiye } \\
\text { etmeyi düşünüyorum. }\end{array}$} & Hayır & 300 & 2,63 & 1,101 & \multirow{2}{*}{, 282} & $-4,788$ & \multirow{2}{*}{$\begin{array}{l}\mathbf{0 0 0} \\
, 000\end{array}$} \\
\hline & Evet & 100 & 3,23 & 1,062 & & $-4,874$ & \\
\hline
\end{tabular}

Infomercial reklamlardan şimdiye kadar satın aldınız mı sorusuna evet diyenler ile hayır diyenler açısından gelecekte satın alma niyeti incelendiğinde evet diyenlerin hayır diyenlere göre gelecekte satın alma niyetine sahip oldukları ( $\mu$ Evet $=2,83$ ve $\mu$ Hayır= 2,37), önümüzdeki 1 hafta içerisinde, 1 ay içerisinde veya 1 yıl içerisinde tekrar satın almayı düşünenlerin, evet diyenlerin olduğu ( $\mu$ Evet $=2,40$ ve $\mu$ Hayır $=2,13),(\mu$ Evet $=2,51$ ve $\mu$ Hayır $=2,16)$ ve $(\mu$ Evet=2,90 ve $\mu$ Hayır=2,32) ve evet diyenlerin infomercial reklamlardan satın aldıkları ürünü arkadaşlarına ve ailelerine tavsiye etmeyi düşündükleri belirlenmiştir( $\mu$ Evet=3,15 ve $\mu$ Hayır=2,62) ve ( $\mu$ Evet=3,23 ve $\mu$ Hayir=2,63). 
Tablo 41: Infomercial Reklamlardan Şimdiye Kadar Satın Alanlar ile Almayanların, Infomercial Reklama Yönelik Genel Tutuma Göre Karşılaştırılması

\begin{tabular}{|c|c|c|c|c|c|c|c|}
\hline Faktör & & $\mathbf{N}$ & Ort. & S.s. & Levene & T testi & P değeri \\
\hline \multirow{2}{*}{$\begin{array}{c}\text { Infomercial reklama yönelik } \\
\text { genel tutum }\end{array}$} & Hayır & 300 & 2,5522 & ,91757 & \multirow{2}{*}{,993 } & \multirow{2}{*}{$\begin{array}{l}-3,602 \\
-3,612\end{array}$} & \multirow{2}{*}{$\begin{array}{l}, 000 \\
, 000\end{array}$} \\
\hline & Evet & 100 & 2,9333 & ,91256 & & & \\
\hline \multicolumn{8}{|l|}{ Soru ifadeleri } \\
\hline \multirow{2}{*}{$\begin{array}{l}\text { Genelde tanıtıcı (infomercial) } \\
\text { reklamlar dikkatimi çekmez } \\
\text { (ters kod) }\end{array}$} & Hayır & 300 & 2,71 & 1,227 & \multirow{2}{*}{,986 } & \multirow{2}{*}{$\begin{array}{l}-2,432 \\
-2,450\end{array}$} & \multirow{2}{*}{$\begin{array}{l}, 015 \\
, 015\end{array}$} \\
\hline & Evet & 100 & 3,05 & 1,209 & & & \\
\hline \multirow{2}{*}{$\begin{array}{l}\text { Genelde tanitıcı(infomercial) } \\
\text { reklamları izlemeyi severim }\end{array}$} & Hayır & 300 & 2,52 & 1,236 & \multirow{2}{*}{,903 } & \multirow{2}{*}{$\begin{array}{l}-2,444 \\
-2,428\end{array}$} & \multirow{2}{*}{$\begin{array}{l}, 015 \\
, 016\end{array}$} \\
\hline & Evet & 100 & 2,87 & 1,253 & & & \\
\hline \multirow{2}{*}{$\begin{array}{l}\text { Genelde tanıtıcı (infomercial) } \\
\text { reklamlara güvenirim. }\end{array}$} & Hayır & 300 & 2,43 & 1,133 & \multirow{2}{*}{,951 } & \multirow{2}{*}{$\begin{array}{l}-3,422 \\
-3,386\end{array}$} & \multirow{2}{*}{$\begin{array}{l}, 001 \\
, 001\end{array}$} \\
\hline & Evet & 100 & 2,88 & 1,157 & & & \\
\hline
\end{tabular}

Infomercial reklamlardan şimdiye kadar satın aldınız mı sorusuna evet diyenlerin $(\mu$ Evet=2,93 $\mu$ Hayır=2,55), infomercial reklama yönelik genel tutumları incelendiğinde, infomercial reklamın dikkatlerini çektiği ( $\mu$ Evet=3,05 ve $\mu$ Hayır=2,71), reklamı izlemeyi sevdikleri ( $\mu$ Evet=2,87 ve $\mu$ Hayır=2,52) ve reklama güvendikleri görülmektedir ( $\mu$ Evet=2,88 ve $\mu$ Hayır=2,43).

Tablo 42: Infomercial Reklamlardan Şimdiye Kadar Satın Alanlar ile Almayanların, Eğlendiricilik, Bilgilendiricilik ve Aldatıcılık Faktörleri Yönünden Karşılaştırılması

\begin{tabular}{|c|c|c|c|c|c|c|c|}
\hline Faktör & & $\mathbf{N}$ & Ort. & S.S. & Levene & T testi & $\begin{array}{c}P \\
\text { değeri }\end{array}$ \\
\hline \multirow{2}{*}{ Ĕglendiricilik } & Hayır & 300 & 2,6067 & 1,06187 & \multirow{2}{*}{,672 } & $-2,759$ & \multirow{2}{*}{$\begin{array}{l}, 006 \\
, 006\end{array}$} \\
\hline & Evet & 100 & 2,9433 & 1,04130 & & $-2,786$ & \\
\hline \multirow{2}{*}{ Bilgilendirici } & Hayır & 300 & 3,1100 & ,84255 & \multirow{2}{*}{,646 } & $-2,754$ & \multirow{2}{*}{$\begin{array}{l}\text {,006 } \\
, 006\end{array}$} \\
\hline & Evet & 100 & 3,3767 & ,82695 & & $-2,779$ & \\
\hline \multirow{2}{*}{ Aldatıcı } & Hayır & 300 & 3,2222 & ,90061 & \multirow[t]{2}{*}{,961 } & 2,840 & \multirow{2}{*}{$\begin{array}{l}\mathbf{0 0 5} \\
, 005\end{array}$} \\
\hline & Evet & 100 & 2,9267 & ,90339 & & 2,835 & \\
\hline
\end{tabular}

Infomercial reklamı eğlendirici ve bilgilendirici olarak algılayanların, infomercial reklamlardan şimdiye kadar satın aldınız mı sorusuna evet diyenler olduğu, ( $\mu$ Evet=2,94 ve $\mu$ Hayır=2,60), ( $\mu$ Evet=3,37 ve $\mu$ Hayır=3,11) infomercial reklamı 
aldatıcı olarak algılayanların ise hayır diyenler olduğu görülmektedir $(\mu$ Hayır $=3,22$ ve $\mu$ Evet=2,92).

Tablo 43: Infomercial Reklamlardan Şimdiye Kadar Satın Alanlar ile Almayanların, Ödeme Şekli ve Hayatı Kolaylaştırma Faktörü Yönünden Karşılaştırılması

\begin{tabular}{|c|c|c|c|c|c|c|c|}
\hline Faktör & & $\mathbf{N}$ & Ort. & S.S. & Levene & T testi & $P$ değeri \\
\hline \multirow{2}{*}{$\begin{array}{c}\text { Ödeme şekli ve hayatt } \\
\text { kolaylaştırma }\end{array}$} & Hayır & 300 & 3,1242 & 1,03951 & \multirow{2}{*}{,176 } & $-2,264$ & \multirow{2}{*}{$\begin{array}{l}, \mathbf{0 2 4} \\
, 019\end{array}$} \\
\hline & Evet & 100 & 3,3900 & ,94503 & & & \\
\hline \multicolumn{8}{|l|}{ Soru ifadeleri } \\
\hline \multirow{2}{*}{$\begin{array}{l}\text { Tanıtıcı (infomercial) reklamlarda } \\
\text { telefon numarası verilmesi benim } \\
\text { satın alma kararımda etkilidir. }\end{array}$} & Hayır & 300 & 2,85 & 1,213 & \multirow{2}{*}{, 514} & $-3,621$ & \multirow{2}{*}{$\begin{array}{l}, \mathbf{0 0 0} \\
, 000\end{array}$} \\
\hline & Evet & 100 & 3,35 & 1,140 & & & \\
\hline \multirow{2}{*}{$\begin{array}{l}\text { Tanıtıcı (infomercial) reklamlarda } \\
\text { internet adresi verilmesi benim satın } \\
\text { alma kararımda etkilidir. }\end{array}$} & Hayır & 300 & 2,90 & 1,225 & \multirow{2}{*}{, 587} & $-3,547$ & \multirow{2}{*}{$\begin{array}{l}, 000 \\
, 000\end{array}$} \\
\hline & Evet & 100 & 3,40 & 1,206 & & & \\
\hline \multirow{2}{*}{$\begin{array}{l}\text { Tanıtıcı (infomercial) reklamların } \\
\text { kargo ile evime teslim edilmesi } \\
\text { benim satın alma kararımda etkilidir. }\end{array}$} & Hayır & 300 & 3,23 & 1,308 & \multirow{2}{*}{,001 } & $-2,505$ & \multirow{2}{*}{$\begin{array}{l}, 013 \\
\mathbf{0 0 8}\end{array}$} \\
\hline & Evet & 100 & 3,60 & 1,137 & & & \\
\hline \multirow{2}{*}{$\begin{array}{l}\text { Tanıtıcı (infomercial) reklamlar } \\
\text { zamandan tasarruf ederek, evden } \\
\text { alışveriş yapma kolaylığı sağladığı } \\
\text { için satın alma kararımda etkilidir. }\end{array}$} & Hayır & 300 & 2,92 & 1,197 & \multirow{2}{*}{,930 } & $-3,270$ & \multirow{2}{*}{$\begin{array}{l}, \mathbf{0 0 1} \\
, 001\end{array}$} \\
\hline & Evet & 100 & 3,37 & 1,178 & & & \\
\hline
\end{tabular}

Infomercial reklamın içeriğindeki ödeme şekli ve hayatı kolaylaştırma faktörü kapsamında, infomercial reklamlardan şimdiye kadar satın aldıklarını görülmektedir ( $\mu$ Evet=3,39 ve $\mu$ Hayır=3,12). Ayrıca infomercial reklamlardan şimdiye kadar satın aldıklarını belirtenlerin, infomercial reklamda telefon numarası $(\mu$ Evet $=3,35$ ve $\mu$ Hayır $=2,85)$ ve internet adresi verilmesinden $(\mu$ Evet $=3,40$ ve $\mu$ Hayır $=2,90)$ ayrica infomercial reklamlardan satın aldıkları ürünlerin kargo ile eve teslim edilmesi ( $\mu$ Evet $=3,60$ ve $\mu$ Hayır=3,23), zamandan tasarruf ederek evden alışveriş yapma kolaylığı sağlaması ( $\mu$ Evet=3,37 ve $\mu$ Hayır=2,92) nedenlerinin satın alma kararında etkili olduğunu ifade etmektedirler. 
Tablo 44: Infomercial Reklamlardan Şimdiye Kadar Satın Alanlar ile

Almayanların, Yorumlar/Kanıtlar/Karşılaştırma Faktörü Yönünden

Karşılaştırılması

\begin{tabular}{|c|c|c|c|c|c|c|c|}
\hline Faktör & & $\mathbf{N}$ & Ort. & S.S. & Levene & T testi & $P$ değeri \\
\hline \multirow{2}{*}{ Yorumlar/kanıtlar/karşılaştırma } & Hayır & 300 & 2,6452 & ,92497 & \multirow{2}{*}{,356 } & $-3,222$ & \multirow{2}{*}{$\begin{array}{l}, \mathbf{0 0 1} \\
, 002\end{array}$} \\
\hline & Evet & 100 & 2,9957 & ,99213 & & $-3,111$ & \\
\hline \multicolumn{8}{|l|}{ Soru ifadeleri } \\
\hline \multirow{2}{*}{$\begin{array}{l}\text { Tanıtıcı (infomercial) reklamlarda ki } \\
\text { memnun tüketicilerin yorumları } \\
\text { benim satın alma kararımda etkilidir. }\end{array}$} & Hayır & 300 & 2,54 & 1,219 & \multirow{2}{*}{,252 } & $-2,365$ & \multirow{2}{*}{$\begin{array}{l}, 019 \\
, 022\end{array}$} \\
\hline & Evet & 100 & 2,88 & 1,274 & & $-2,314$ & \\
\hline \multirow{2}{*}{$\begin{array}{l}\text { Tanıtıcı (infomercial) reklamlarda ki } \\
\text { uzman kişinin yorumları benim satın } \\
\text { alma kararımda etkilidir. }\end{array}$} & Hayır & 300 & 2,67 & 1,243 & \multirow{2}{*}{,258 } & $-3,144$ & \multirow{2}{*}{$\begin{array}{l}, \mathbf{0 0 2} \\
, 002\end{array}$} \\
\hline & Evet & 100 & 3,12 & 1,192 & & $-3,211$ & \\
\hline \multirow{2}{*}{$\begin{array}{l}\text { Tanıtıcı (infomercial) reklamlarda ki } \\
\text { sunucu benim satın alma kararımda } \\
\text { etkilidir. }\end{array}$} & Hayır & 300 & 2,38 & 1,113 & \multirow{2}{*}{,028 } & $-2,298$ & \multirow{2}{*}{$\begin{array}{l}, 022 \\
, \mathbf{0 3 0}\end{array}$} \\
\hline & Evet & 100 & 2,68 & 1,230 & & $-2,186$ & \\
\hline \multirow{2}{*}{$\begin{array}{l}\text { Televizyon veya reklam filmlerinden } \\
\text { tanıdığım birinin/ünlünün, tanıııcı } \\
\text { (infomercial) reklamlarda, ürün } \\
\text { hakkında konuşması satın alma } \\
\text { kararımda etkilidir. }\end{array}$} & Hayır & 300 & 2,40 & 1,153 & \multirow{2}{*}{,285 } & & \multirow{2}{*}{$\begin{array}{l}, \mathbf{0 0 1} \\
, 002\end{array}$} \\
\hline & Evet & 100 & 2,84 & 1,220 & & $-3,189$ & \\
\hline \multirow{2}{*}{$\begin{array}{l}\text { Tanıtıcı (infomercial) reklamlarda } \\
\text { sipariş verdiğimde yanında verilen } \\
\text { hediyeler/ek ürünler (bıçak seti } \\
\text { yanında yemek kitabı/bir alana ikinci } \\
\text { üründe hediye gibi) satın alma } \\
\text { kararımda etkilidir. }\end{array}$} & Hayır & 300 & 2,76 & 1,219 & \multirow[t]{2}{*}{,138 } & \multirow[t]{2}{*}{$\begin{array}{l}-2,509 \\
-2,609\end{array}$} & \multirow[t]{2}{*}{$\begin{array}{l}, \mathbf{0 1 3} \\
, 010\end{array}$} \\
\hline & Evet & 100 & 3,11 & 1,127 & & & \\
\hline \multirow{2}{*}{$\begin{array}{l}\text { Farklı işlevlerdeki pek çok ürün } \\
\text { yerine tüm işlevlerin tek bir üründe } \\
\text { toplandığını gösteren tanıtıcı } \\
\text { (infomercial) reklamlar satın alma } \\
\text { kararımda etkilidir. }\end{array}$} & Hayır & 300 & 2,91 & 1,159 & \multirow[t]{2}{*}{, 860} & \multirow{2}{*}{$\begin{array}{l}-2,645 \\
-2,653\end{array}$} & \multirow{2}{*}{$\begin{array}{l}\mathbf{0 0 8} \\
, 009\end{array}$} \\
\hline & Evet & 100 & 3,26 & 1,151 & & & \\
\hline
\end{tabular}

Infomercial reklamlardan şimdiye kadar satın alanların, infomercial reklam içeriğine ait yorumlar, kanıtlar ve karşılaştırma faktörü kapsamında görülmektedir ( $\mu$ Evet=2,99 ve $\mu$ Hayır=2,64). infomercial reklamda yer alan memnun kullanic1 yorumları ( $\mu$ Evet=2,88 ve $\mu$ Hayır=2,54), uzman yorumları ( $\mu$ Evet=3,12 ve $\mu$ Hayır=2,67), sunucu yorumları ( $\mu$ Evet=2,68 ve $\mu$ Hayır=2,38), infomercial reklamlarda rol alan ünlüler ( $\mu$ Evet=2,84 ve $\mu$ Hayır=2,40), ürünün yanında verilen ek ürünler/bonuslar ( $\mu$ Evet=3,11 ve $\mu$ Hayır=2,76) ve infomercial reklamda satın ürünün farklı işlevlerdeki tek bir ürün olması ( $\mu$ Evet=3,26 ve $\mu$ Hayır=2,91) satın alma kararında etkili olduğu belirlenmiştir. 
Tablo 45: Infomercial Reklamlardan Şimdiye Kadar Satın Alanlar ile Almayanların, Satın Almadan Önceki Ürün hk. Düşünce Faktörü Yönüden Karşılaştırılması

\begin{tabular}{|c|c|c|c|c|c|c|c|}
\hline Faktör & & $\mathbf{N}$ & Ort. & S.S. & Levene & T testi & $P$ değeri \\
\hline \multirow{2}{*}{$\begin{array}{c}\text { Satın almadan önceki ürün hk. } \\
\text { düşünce }\end{array}$} & Hayır & 300 & 3,1878 & ,95179 & \multirow{2}{*}{,096 } & $-3,403$ & \multirow{2}{*}{$\begin{array}{l}, \mathbf{0 0 1} \\
, 000\end{array}$} \\
\hline & Evet & 100 & 3,5533 & ,86225 & & $-3,575$ & \\
\hline \multicolumn{8}{|l|}{ Soru ifadeleri } \\
\hline \multirow{2}{*}{$\begin{array}{l}\text { Tanıtıcı (infomercial) reklamlar satın } \\
\text { almadan önce ürün hakkında } \\
\text { düşünmemi sağlar }\end{array}$} & Hayır & 300 & 3,16 & 1,049 & \multirow{2}{*}{,856 } & \multirow{2}{*}{$\begin{array}{l}-2,620 \\
-2,632\end{array}$} & \multirow{2}{*}{$\begin{array}{l}, 009 \\
, 009\end{array}$} \\
\hline & Evet & 100 & 3,48 & 1,039 & & & \\
\hline \multirow{2}{*}{$\begin{array}{l}\text { Tanıtıcı (infomercial) reklamlarda } \\
\text { bir ürünü neden satın almam } \\
\text { gerektiğini söyler. Bu nedenler } \\
\text { hakkında düşünürüm. }\end{array}$} & Hayır & 300 & 2,99 & 1,115 & \multirow[b]{2}{*}{,124 } & \multirow{2}{*}{$\begin{array}{l}-3,452 \\
-3,652\end{array}$} & \multirow{2}{*}{$\begin{array}{l}, 001 \\
, 000\end{array}$} \\
\hline & Evet & 100 & 3,42 & ,997 & & & \\
\hline \multirow{2}{*}{$\begin{array}{l}\text { Tanıtıcı (infomercial) reklamlardan } \\
\text { satın almaya karar vermeden önce, } \\
\text { ürünün fayda sağlayıp, } \\
\text { saylamayacağı hakkında düsünürüm }\end{array}$} & Hayır & 300 & 3,41 & 1,131 & \multirow{2}{*}{,035 } & \multirow{2}{*}{$\begin{array}{l}-2,714 \\
-2,850\end{array}$} & \multirow{2}{*}{$\begin{array}{l}\mathbf{0 0 7} \\
, 005\end{array}$} \\
\hline & Evet & 100 & 3,76 & 1,026 & & & \\
\hline
\end{tabular}

Infomercial reklamlardan şimdiye kadar satın alan izleyicilerin, infomercial reklamdan satın almadan önce ürün hakkında düşündükleri görülmektedir ( $\mu$ Evet=3,55 ve $\mu$ Hayır=3,18). Bu faktör kapsamında şimdiye kadar satın alanlar, infomercial reklamın; ürün hakkında ( $\mu$ Evet=3,48 ve $\mu$ Hayır=3,16), ürünü neden satın alınması gerektiği konusunda ( $\mu$ Evet=3,42 ve $\mu$ Hayır=2,99), ürünün fayda sağlayıp sağlamayacağı hakkında ( $\mu$ Evet=3,41 ve $\mu$ Hayır=3,76) düşünmelerini sağladığ1 belirlenmiştir.

Tablo 46: Infomercial Reklamlardan Şimdiye Kadar Satın Alanlar ile Almayanların, Satın Almadan Önceki Reklam hk. Düşünce Faktörü Yönüden Karşılaştırılması

\begin{tabular}{|c|c|c|c|c|c|c|c|}
\hline Faktör & & $\mathbf{N}$ & Ort. & S.s. & Levene & T testi & P değeri \\
\hline \multirow{2}{*}{$\begin{array}{c}\text { Satın almadan önceki reklam hk. } \\
\text { düşünce }\end{array}$} & Hayır & 300 & 2,7258 & ,77457 & \multirow{2}{*}{,352 } & $-3,374$ & \multirow{2}{*}{$\begin{array}{l}, 001 \\
, 001\end{array}$} \\
\hline & Evet & 100 & 3,0325 & ,82393 & & $-3,271$ & \\
\hline \multicolumn{8}{|l|}{ Soru ifadeleri } \\
\hline \multirow{2}{*}{$\begin{array}{l}\text { Bir ürünün diğer ürünlerle } \\
\text { benzerliğine televizyon } \\
\text { reklamlarından bakarım. }\end{array}$} & Hayır & 300 & 2,72 & ,997 & \multirow{2}{*}{,620 } & $-2,611$ & \multirow{2}{*}{$\begin{array}{l}, 009 \\
, 011\end{array}$} \\
\hline & Evet & 100 & 3,02 & 1,035 & & $-2,562$ & \\
\hline Televizyon reklamında görmeden & Hayır & 300 & 2,51 & 1,026 & ,793 & $-3,870$ &, 000 \\
\hline
\end{tabular}




\begin{tabular}{|l|c|c|c|c|c|c|c|}
\hline $\begin{array}{l}\text { önce, bir ürüne ihtiyacım olduğunu } \\
\text { fark etsem bile, asla hiçbir ürüne } \\
\text { bakmam. }\end{array}$ & Evet & $\mathbf{1 0 0}$ & $\mathbf{2 , 9 7}$ & 1,068 & & $-3,794$ &, 000 \\
\hline $\begin{array}{l}\text { Tanıtıcı (infomercial) reklamlardan } \\
\text { satın almadan önce reklam hakkında } \\
\text { çok düşünürüm. }\end{array}$ & Hayır & 300 & 2,83 & 1,110 & \multirow{2}{*069}{} & $\begin{array}{l}-2,089 \\
-2,228\end{array}$ & $\begin{array}{r}, \mathbf{0 3 7} \\
\text {,027 }\end{array}$ \\
\cline { 2 - 6 }
\end{tabular}

Infomercial reklamlardan şimdiye kadar satın alan izleyicilerin, infomercial reklamdan satın almadan önce reklam hakkında düşündükleri görülmektedir ( $\mu$ Evet=3,03 ve $\mu$ Hayır=2,72). Bu faktör kapsamında şimdiye kadar satın alanların, infomercial reklamda, bir ürünün diğer ürünlerle benzerliğine infomercial reklamlardan baktıkları ( $\mu$ Evet=3,02 ve $\mu$ Hayır=2,72), infomercial reklamda gördüğünde o ürüne ihtiyaç duyduğu ( $\mu$ Evet=2,97 ve $\mu$ Hayır=2,51) ve ürünü satın almadan önce infomercial reklam hakkında düşündüğü ( $\mu$ Evet=3,09 ve $\mu$ Hayır=2,83) görülmektedir.

Tablo 47: Infomercial Reklamlardan Şimdiye Kadar Satın Alanlar ile Almayanların,Saatlik Televizyon İzleme Alışkanlıkları Açısından Karşılaştırılması

\begin{tabular}{|l|c|c|c|c|c|c|c|}
\hline Faktör & & $\mathbf{N}$ & Ort. & S.s. & Levene & T testi & P değeri \\
\hline \multirow{2}{*}{$\begin{array}{l}\text { Hangi saatler arasında tv } \\
\text { izlersiniz? }\end{array}$} & Hayır & $\mathbf{3 0 0}$ & $\mathbf{4 , 3 1}$ & 1,112 & \multirow{2}{*}{$\mathbf{0 0 0}$} & $\begin{array}{r}3,667 \\
3,249\end{array}$ & $\begin{array}{r}, 000 \\
\mathbf{, 0 0 1}\end{array}$ \\
\cline { 2 - 8 } & Evet & 100 & 3,80 & 1,421 & & \\
\hline
\end{tabular}

Yapılan analiz sonucunda infomercial reklamlardan şimdiye kadar satın aldınız mı sorusuna hayır diyenlerin saatlik televizyon izleme alışkanlıkları açısından farklı alışkanlıklara sahip oldukları belirlenmiştir ( $\mu$ Hayır=4,31 ve $\mu$ Evet=3,80). Bu bağlamda sadece hayır yanıtını veren 300 kişi incelendiğinde \%48'lik kesiminin 20.0123.00 saatleri arasında televizyon izledikleri belirlenmiştir. (bk.Tablo: 48)

Tablo 48: Infomercial Reklamlardan Şimdiye Kadar Satın Almayanların,Saatlik Televizyon İzleme Alışkanlıkları

\begin{tabular}{|c|c|c|}
\hline & Frekans & Yüzde \\
\hline $06.00-10.00$ & 11 & 2,8 \\
\hline $10.01-12.00$ & 21 & 5,3 \\
\hline $12.01-19.00$ & 24 & 6,0 \\
\hline $19.01-20.00$ & 53 & 13,3 \\
\hline $\mathbf{2 0 . 0 1 - 2 3 . 0 0}$ & $\mathbf{1 9 1}$ & $\mathbf{4 7 , 8}$ \\
\hline Total & 300 & 75,0 \\
\hline Hesaplanmayan & 100 & 25,0 \\
\hline Total & 400 & 100,0 \\
\hline
\end{tabular}




\subsection{Araştırma Bulgularının Değerlendirilmesi}

Demografik özelliklere ve tv izleme alıskanlıklarına yönelik bulguların $\underline{\text { değerlendirilmesi }}$

Araştırmaya katılan 400 katılımcının \%46'sının erkek, \%53'ünün ise kadın olduğu görülmektedir. Araştırmaya katılanların yaş dağılımına bakıldığında, \%39'luk bir kesimin 25-34 yaş aralığında, \%47'lik bir kısmının bekar, diğer \%47'lik kısmının ise evli olduğu, \%57'lik bir kesiminin ise çocuğunun olmadığ1 görülmektedir. Araştırmaya katılanların aylık gelir düzeyine göre dağılımına bakıldığında \%32'lik kesimin 750 TL ve altında bir gelire sahip oldukları, \%43'lük bir kesimin ise haneye giren aylık gelirlerinin 2000 TL'den daha az olduğu belirlenmiştir. Araştırmaya katılanların \%37'lik kısmının üniversite düzeyinde eğitime sahip oldukları, \%14'ünün ev hanımı, \%14'ünün öğrenci, \%8'inin emekli ve \%6'sının öğretmen olduğu belirlenmiştir.

Infomercial reklamlardan bugüne kadar alışveriş edenlerin, ankete katılan 400 kişinin \%25'i olduğu ve alışveriş eden 100 katılımcının \%6'lık kısmının ev gereçleri satın aldıkları görülmektedir.

Araştırmaya katılan 400 kişinin \%45'i hafta içi ve hafta sonu genellikle televizyon izlediğini, \%59' u ise 20.01-23.00 saatleri arasında televizyon izlediğini belirtmiştir.

\section{Ölçeklerin açıklayıcı ve doğrulavıcı faktör analizi ile değgerlendirilmesi}

Başlangıç modelinde yer alan infomercial reklama yönelik algı, alıcının kişilik özellikleri ve infomercial reklam içeriği ölçekleri ilk olarak açıklayıcı faktör analizine, daha sonra ise doğrulayıcı faktör analizine tabi tutulmuştur. 


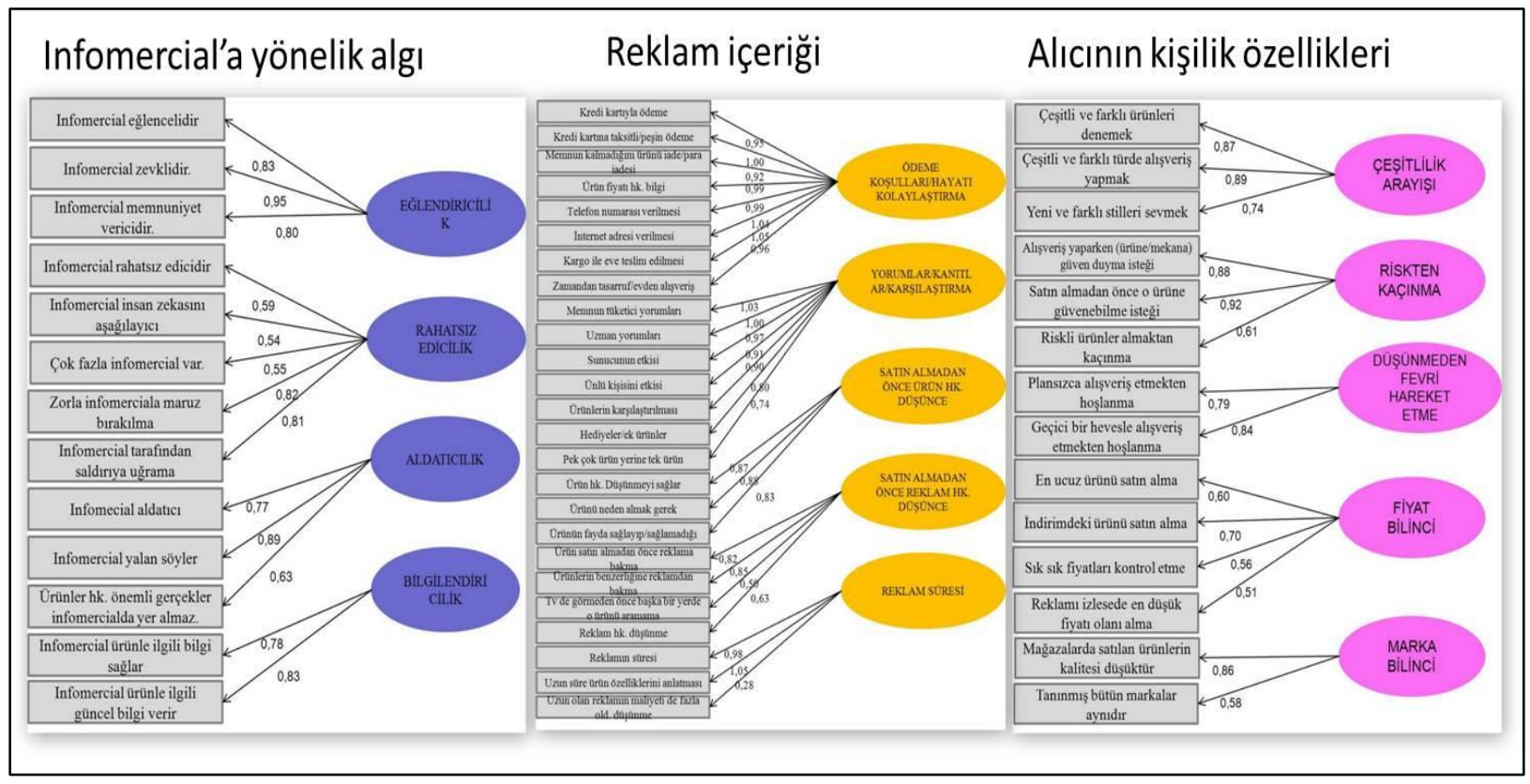

Infomercial reklama yönelik algı ölçeği açıklayıcı ve doğrulayıcı faktör analizine tabi tutulduğunda,

Infomercial reklama yönelik algı ölçeğinde, Ducoffe'nin 1995 yılında yaptığı Reklam Değeri çalışmasındaki eğlendiricilik, bilgilendiricilik, aldatıcılık ve rahatsız edicilik alg1 faktörlerinden yararlanılmış, buna ek olarak Shavit, Lowrey ve Haefner'ın 1998 yılında yapmış olduğu Reklama Yönelik Halkın Tutumu çalışmasından rahatsız edicilik faktörü ile ilişkili soru ifadeleri eklenmiştir. Bu bağlamda Türk kültürü ile uyum sağlayıp sağlamadığı belirlenmek amacıyla, ölçek açıklayıcı ve doğrulayıcı faktör analizine tabii tutulmuştur.

Açıklayıcı faktör analizinde; Infomercial reklamlar ürünle ilgili bilgi sağlar, ürün ile ilgili güncel bilgi verir, ürünle ilgili bilgiyi insanlar ihtiyaç duyduklarında verir ifadeleri "bilgilendiricilik" faktörü altında anlamlı bir şekilde toplanmıştır. Bilgilendiricilik faktörü doğrulayıcı faktör analizine tabii tutulduğunda ise bu faktörlerden hariç 'ürünle ilgili bilgiyi insanlar ihtiyaç duyduklarında verir' ifadesinin ise yer almadığı görülmektedir.

Alıcının kişilik özellikleri ölçeği açıklayıcı ve doğrulayıcı faktör analizine tabii tutulduğunda,

Infomercial reklamlardan satın alan kişiler ile satın almayan kişilerin özelliklerinin karşılaştırıldığı, Donthu ve Gilliland'ın 1996 yılında yaptığı, Infomercial 
Reklam Müşterisi çalışmasındaki marka bilinci, fiyat bilinci, çeşitlilik arayışı, düşünmeden/fevri davranma, yenilikçilik, riskten kaçınma faktörlerinden yararlanılmış, buna ek olarak Shavit, Lowrey ve Haefner'ın 1998 yılında yapmış olduğu Reklama Yönelik Halkın Tutumu çalışmasından marka bilinci ve fiyat bilinci faktörlerine yönelik soru ifadeleri eklenmiştir. Bu bağlamda ölçek açıklayıcı ve doğrulayıcı faktör analizine tabii tutulmuştur.

Açıklayıcı faktör analizinde; Daima alışveriş listesine sadık kalma, plansızca alışveriş etme, geçici bir hevesle bir şeyler alma, alışveriş etmeden önce iki kere düşünme ifadeleri "düşünmeden/fevri hareket etme" faktörü altında anlamlı bir şekilde toplanmaktadır. Doğrulayıcı faktör analizine tabii tutulduğunda ise, bu faktörlerden hariç, "alışveriş listesine sadık kalma" ve "alışveriş etmeden önce iki kere düşünme" ifadesi analizde yer almamaktadır.

Açıklayıcı faktör analizinde; Genellikle indirimdeki ürünü satın alma, en ucuz ürünü satın alma, sık sık fiyatları kontrol etme ve reklamları izledikten sonra yine de en düşük fiyatı olan ürünü satın alma ifadeleri ise, "fiyat bilinci" faktörü altında toplanmaktadır. Doğrulayıcı faktör analizine tabii tutulduğunda ise, bu faktörlerden hariç 'reklamları izledikten sonra yine de en düşük fiyatı olanı satın alma' ifadesi analizde yer almamaktadır.

Infomercial reklam içeriği ölçeği açıklayıcı ve doğrulayıcı faktör analizine tabii tutulduğunda,

Infomercial reklamlardan satın alan müşterilerin infomercial reklam etkinliğginden beklentilerinin araştırıldığı Martin, Bhimy ve Agee'nin 2002 yılındaki çalışmalarında 'yorumlar ve kanıtlar', ‘ödeme koşulları', 'hayatı kolaylaştırma', 'tanıma/karşılaştırma/ekstralar' faktörlerinden yararlanılmıştır. Buna ek olarak odak grup sonuçlarından ve Donthu ve Gilliland'ın çalışmasından ifadeler eklenmiştir. Bu bağlamda ölçek açıklayıcı ve doğrulayıcı faktör analizine tabii tutulmuştur.

Açıklayıcı faktör analizinde; Infomercial reklamlarda kredi kartına taksitli/peşin ödeme koşulları, ürünün fiyatı hakkında bilgi verilmesi, memnun kalınmayan ürünü iade edildiğinde para iade garantisi, kredi kartıyla ödeme yapılabilmesi, internet adresi verilmesi, zamandan tasarruf ederek evden alışveriş yapma kolaylığı sunması, satın alınan ürünlerin kargo ile eve teslim edilmesi, telefon 
numarası verilmesi ifadeleri “ödeme şekli ve hayatı kolaylaştırma” faktörü altında anlamlı bir şekilde bir araya gelmektedir. Burada ölçekten farklı olarak iki faktörün bir faktörde yer aldığı görülmektedir. Türk tüketicisine göre hayatı kolaylaştırma unsuru ile ödeme koşulları unsurunun bir arada algılandı̆̆ı görülmektedir.

Açıklayıcı faktör analizinde; Infomercial reklamlardaki sunucu, memnun tüketicilerin yorumları, uzman kişinin yorumları, televizyondan ya da reklamlardan tanınan bir ünlünün ürün hakkında konuşması, ürünlerin yararlarının karşılaştırılması, ürün siparişi verildiğinde yanında verilen ek ürünler/hediyeler, farklı işlevlerdeki pek çok ürün yerine tek bir üründe toplandığını gösteren reklamların satın alma kararını etkilediğini belirten ifadeler "yorumlar/kanıtlar/karş1laştırma" faktörü kapsamında anlamlı bir şekilde bir araya gelmiştir. Burada ölçekten farklı olarak iki faktörün bir faktörde toplandığı görülmektedir. Türk tüketicisine göre yorumlar ve kanıtlar unsuru ile tanıma/karşılaştırma/ekstralar unsuru bir arada algılanmaktadır. $\mathrm{Bu}$ nedenle bu faktöre 'yorumlar/kanıtar/karşılaştırma' faktörü ismi verilmiştir.

Açıklayıcı faktör analizinde; Infomercial reklamlardan satın almaya karar vermeden önce ürünün fayda sağlayıp sağlamayacağı hakkında, ürün hakkında ve bir ürünün neden satın alınması gerektiği hakkında düşünmemi sağlar ifadeleri "satın almadan önceki ürün hakkında düşünce" faktörü kapsamında toplanmıştır. Burada ise yine ölçekten farklı olarak satın almadan önceki düşünce faktörü iki şekilde algılanmaktadır. Bu nedenle biri için "satın almadan önceki ürün hakkında düşünce" ismi verilirken, diğeri için "satın almadan önceki reklam hakkında düşünce" ismi verilmiştir.

Doğrulayıcı faktör analizinde ise, ölçek faktörleri ile bir bütün olarak değerlendirildiğinde, güvenilirlikleri sağlamadığı için analizden geçememiştir.

Tutum faktörü ve satın alma kararı değişkenleri açıklayıcı ve doğrulayıcı faktör analizine tabii tutulduğunda;

Shimp'in 1981 y1lında reklam tutumunun duygusal boyutundan bahsettiği çalışmasından yola çıkılarak, infomercial reklama yönelik genel tutum ifadeleri Shavit, Lowrey ve Haefner'in 1998 yılındaki Reklama Yönelik Tutum çalışmasındaki ifadeler ile oluşturulmuş, Donthu ve Gilliand'ın 1996 yılındaki çalışmasından ise soru eklenmiştir. 
Açıklayıcı faktör analizine göre, genelde infomercial reklamları sevme, dikkatini çekme ve güven ifadeleri "tutum” faktörünü oluşturmaktadır. Doğrulayıcı faktör analizinde ise, dikkatini çekme ifadesi yer bulamamaktadır. Doğrulayıcı faktör analizi ile "tutum” faktörü tek boyuttan oluştuğu için gösterilememektedir.

Infomercial reklamlardan önümüzdeki bir ay içinde, bir y1l içinde ve bir hafta için tekrar satın almayı düşünüyorum ifadeleri ile satın aldığım ürünü aileme, arkadaşlarıma tavsiye ederim ifadelerinden oluşan "gelecekteki satın alma niyeti" faktörü ile infomercial reklamlardan doğru ürün seçimi yapabilmek önemlidir, infomercial reklamlarda gösterilen pek çok marka ve ürün arasından seçim yaparken hangi ürünü satın alacağım önemlidir, infomercial reklamlardan bir ürün seçerken, seçimimin sonucunda beni tatmin edip etmeyeceği ile ilgili endişeleniyorum ve tanıtıcı reklamlardaki çeşitli tür ve markalardaki ürünler birbirine benzemektedir ifadeleri "satın alma niyeti” faktörünü oluşturmaktadır. Doğrulayıcı faktör analizinde ise gelecekte satın alma niyeti faktörleri bir arada anlamlı şekilde bir araya gelirken, satın alma niyeti faktörü güvenilirlikten geçememiştir.

Faktörlerin demografik özellikler ve tv izleme alıskanlıklart açısından değerlendirilmesi

Eğlendiricilik açısından demografik ve tv izleme alışkanlıkları dĕgerlendirildiğinde,

- Infomercial reklamları medeni durumu dul olan grubun evli ve bekâr olanlara göre; televizyonu hafta içi her gün izleyenlerin, hafta içi bazı günlerde izleyenlere göre infomercial reklamları daha eğlendirici olarak algıladıkları görülmüştür.

Aldatıcılık açısından demografik ve tv izleme alışkanlıkları dĕgerlendirildiğinde,

- Infomercial reklamları medeni durumu bekâr olan grubun dul olanlara göre daha aldatıcı olarak algıladıkları görülmüştür.

Bilgilendiricilik açısından demografik ve tv izleme alışkanlıkları dĕgerlendirildiğinde,

- Infomercial reklamları 55-64 yaş grubunun, 25-34 yaş grubuna göre; medeni durumu dul olanların evli ve bekâr olanlara göre daha bilgilendirici olarak 
algıladıkları görülmüştür. Ayrıca televizyonu hafta içi her gün izleyenlerin, sadece hafta sonunda izleyenlere göre infomercial reklamları daha bilgilendirici olarak algıladıkları görülmektedir.

Çeşitlilik arayışı açısından demografik ve tv izleme alışkanlıkları dĕgerlendirildiğinde,

- 16-34 yaş arasındaki grubun 45-54 orta yaş grubuna göre daha fazla çeşitlilik aradığı görülmüştür.

Riskten kaçınma açısından demografik ve tv izleme alışkanlıkları dĕgerlendirildiğinde,

- Hanesine ayda ortalama 3001-3500 TL giren grubun, hanesine ayda ortalama 751-1500 TL ve 5001 TL ve üstü giren gelir gruplarına göre, hanesine ayda ortalama 3501-4000 TL giren grubun, hanesine ayda ortalama 751-1500 TL, 2001-2500 TL ve 5001 TL ve üstü giren gelir gruplarına göre, hanesine ayda ortalama 2501-3000 TL giren grubun, hanesine ayda ortalama 5001 TL ve üstü giren gelir gruplarına göre riskli ürünler almaktan kaçındıkları görülmüştür. Ayrıca medeni durumu evli olanların, boşanmışlara göre riskli ürünler almaktan kaçındıkları belirlenmiştir.

Düşünmeden fevri hareket etme açisından demografik ve tv izleme alışkanlıkları de ğerlendirildiğinde,

- 16-24 yaş arasındaki grubun 25-34 orta yaş grubuna göre daha düşüncesizce hareket ettiği görülmüştür. Ayrıca televizyonu “06.00-10.00” saatleri arasında izleyenlerin "20.01-23.00” saatleri arasında izleyenlere göre daha düşüncesizce/fevri hareket etme özelliğine sahip oldukları görülmektedir.

Marka bilinci açısından demografik ve tv izleme alışkanlıkları de ğerlendirildiğinde,

- Televizyonu sadece hafta sonu izleyenlerin, hafta içi bazı günlerde izleyenlere göre daha fazla marka bilincine sahip oldukları anlaşılmıştır.

Ödeme şekli ve hayatı kolaylaştırma açısından demografik ve tv izleme alışkanlıkları dĕgerlendirildiğinde, 
- $\quad$ Televizyonu hafta içi her gün, hafta içi bazı günler ve hafta içi ve hafta sonu genellikle izleyenlerin, sadece hafta sonunda izleyenlere göre infomercial reklamdaki ödeme koşullarından ve hayatı kolaylaştırmasından daha fazla etkilendikleri belirlenmiştir.

Yorumlar/kanıtlar/karşılaştırma açısından demografik ve tv izleme alışkanlıkları de ğerlendirildiğinde,

- Televizyonu "06.00-10.00" saatleri arasında izleyenlerin "19.01-23.00" saatleri arasında izleyenlere göre infomercial reklam içeriğindeki yorum/kanıt veya karş1laştırmalardan daha fazla etkilendikleri görülmektedir.

Satın almadan önce ürün hakkındaki düşünce açısından demografik ve tv izleme alışkanlıkları değerlendirildiğinde,

- Kadınların infomercial reklamlardan satın almadan önce ürün hakkında erkeklere göre daha fazla düşündüğü belirlenmiştir.

Satın almadan önceki reklam hakkındaki düşünce açısından demografik ve tv izleme alışkanlıkları değgerlendirildiğinde,

- Televizyonu hafta içi her gün izleyenlerin sadece hafta sonu izleyenlere göre; televizyonu "06.00-10.00” saatleri arasında izleyenlerin “20.01-23.00” saatleri arasında izleyenlere göre satın almadan önceki reklam hakkındaki düşünceye sahip oldukları görülmektedir.

Reklam süresi, Rahatsız edicilik ve Fiyat bilinci faktörleri açısından hiçbir farklılığın bulunmadı̆̆ belirlenmiştir. 


\section{$\underline{\text { Yapısal Essitlik Modeli ile Modelin Analiz Edilmesi }}$}

\section{Şekil 35:Modelin Önceki Ve Sonraki Halleri}
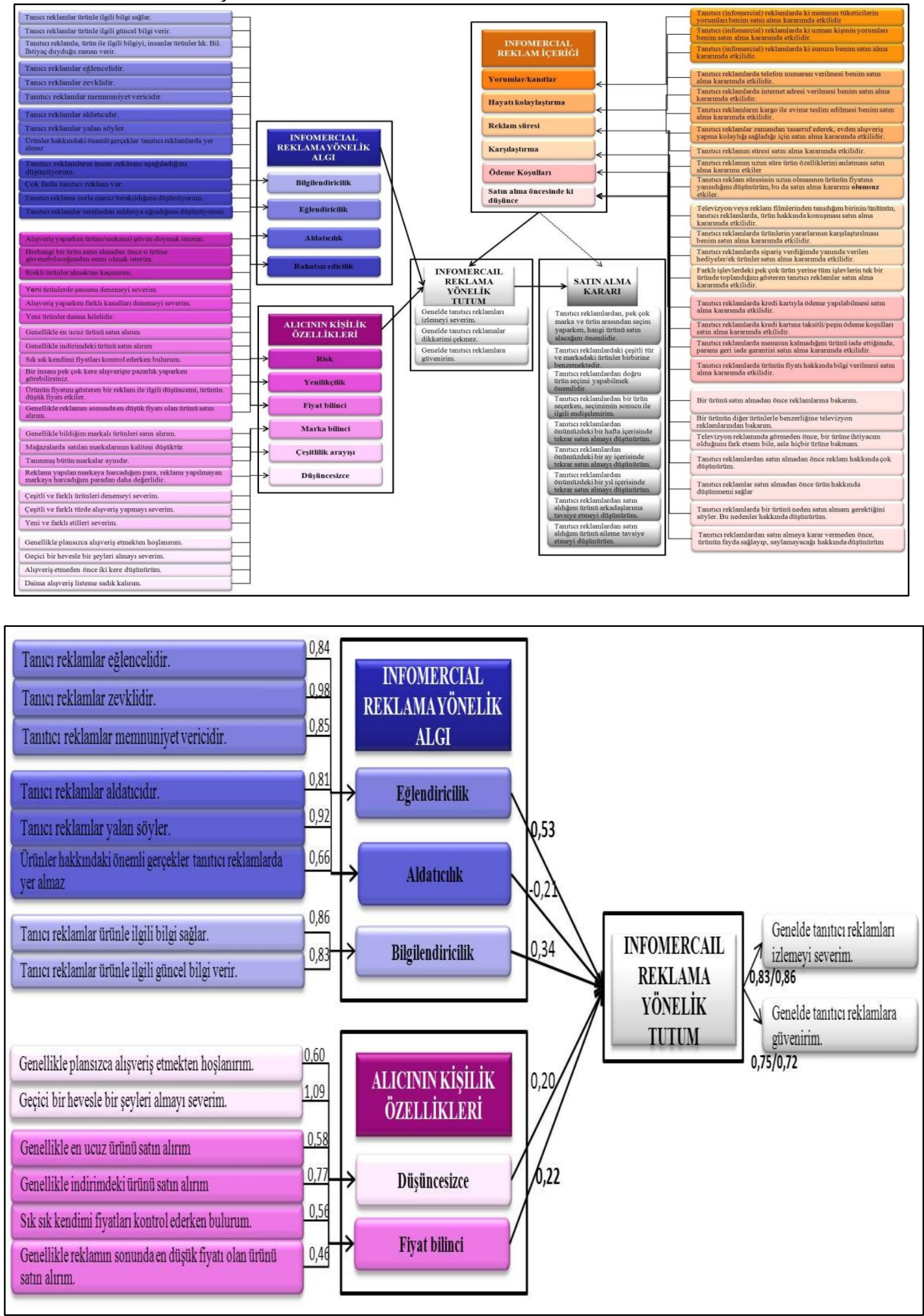

Başlangıç modelinde infomercial reklama yönelik algı, alıcının kişilik özellikleri ve infomercial reklam içeriği olmak üzere üç ölçekten oluşturulmuş modelin 
tutumu etkilediği ve tutumunda satın alma kararını etkilediği varsayılmıştır. Fakat iterasyonlar sonucunda iki model meydana gelmiştir. Bunlardan biri infomercial reklama yönelik algıya yönelik eğlendiricilik, bilgilendiricilik ve aldatıcılık faktörlerinin tutumu doğrudan etkilendiği model, diğeri ise alıcının kişilik özelliklerinden düşüncesizce/fevri hareket etme ve fiyat bilinci faktörlerinin tutumu doğrudan etkilediği model şeklindedir. Her iki modelinde satın alma kararını etkilemediği görülmektedir.

Infomercial reklama yönelik alg1 faktörlerinin tutumu etkilediği gösterilen modelde eğlendiricilik-tutum arasında ve bilgilendiricilik-tutum arasında pozitif bir ilişki aldatıcılık-tutum arasında ise negatif bir ilişki olduğu görülmektedir. Eğlendiricilik, aldatıcılık ve bilgilendiricilik faktörlerinin doğrudan tutuma olan etkisi görülmekteyken, Ducoffe'un ölçeğinde yer alan rahatsız edicilik faktörünün bu modelde yer bulmadığı görülmektedir. Ducoffe'un 15 maddelik ölçeğinde reklam tutumu reklam değerine bağlıdır. Yani eğlendiricilik ve bilgilendiricilik faktörleri reklam değeri ile pozitif, rahatsız edicilik ve aldatıcılık faktörleri ise reklam değeri ile negatif ilişkilidir. Buna rağmen Çakır'ların 2007'de yaptığı çalışmaya göre, bilgilendiricilik ve eğlendiricilik faktörleri reklam değerini etkiler. Reklam değeri de reklam tutumunu etkilemekte, yani bu iki faktörün hem doğrudan hem de reklam değeri dolayısıyla reklam tutumunu etkilediği görülmektedir. Reklamın rahatsız edici oluşu hem geleneksel reklamlarda hem de infomercial reklamlarda tutumu etkilememektedir. Bununla birlikte, hem reklam tutumunu, hemde infomercial reklama yönelik tutumu olumlu etkileyen iki önemli unsur karşımıza çıkmaktadır. Bunlardan biri eğlendiricilik unsuru iken, diğeri bilgilendiricilik unsurudur. (ÇAKIR, et al., 2007)

Alıcının kişilik özellikleri faktörlerinin tutumu etkilediği gösterilen modelde düşüncesizce/fevri hareket etme - tutum arasında ve fiyat bilinci - tutum arasında pozitif bir ilişki olduğu görülmektedir. $\mathrm{Bu}$ sonuç bize şunu göstermektedir ki, infomercial reklamlara yönelik olumlu tutumu olan kişilerin özelliklerinden biri hiç düşünmeden alışveriş yapmak iken, bir diğeri de fiyat bilincine sahip olmalarıdır. Bu her ne kadar tezat gibi görünüyor olsa da, satın alanlar ile satın almayanların karşılaştırılması sonucunda, bu etkinin anlamlı olduğu anlaşılacaktır.

Sonuç olarak, ilk modelden yola çıkılarak elde edilen iki model arasından, tutumu etkileyen algı modeli, bu çalışmada kabul edilmektedir. Literatürde de reklam üzerine yapılan çalışma da yapısal eşitlik modelinin uygulandığı bu model, infomercial reklama da uyarlandığında benzer sonuçlar verdiği görülmektedir. 
Infomercial Reklamlardan Simdive Kadar Ürün Satın Alanlar İle Almayanların Karșllaștırılarak Dĕgerlendirilmesi

Tablo 49: Infomercial Reklamlardan Ürün Satın Alanlar ile Satın Almayanların Karşılaştırılması T-Testi

\begin{tabular}{|c|c|c|}
\hline Hipotezler & $\begin{array}{l}\text { Infomercial reklamdan } \\
\text { ürün satın alanlar } \\
\qquad(\mathrm{n}=100)\end{array}$ & $\begin{array}{l}\text { Infomercial reklamdan } \\
\text { ürün satın almayanlar } \\
\qquad(\mathrm{n}=300)\end{array}$ \\
\hline $\begin{array}{l}\text { Infomercial reklamlardan } \\
\text { gelecekte satın alma niyeti }\end{array}$ & $2,8 \sqrt{ }$ & 2,3 \\
\hline $\begin{array}{l}\text { Infomercial reklama yönelik } \\
\text { genel tutum }\end{array}$ & $2,9 \sqrt{ }$ & 2,5 \\
\hline Ĕglendiricilik & $2,9 \sqrt{ }$ & 2,6 \\
\hline Bilgilendirici & $3,3 \sqrt{ }$ & 3,1 \\
\hline Aldatıcı & 2,9 & $3,2 \sqrt{ }$ \\
\hline $\begin{array}{l}\text { Ödeme şekli ve hayatı } \\
\text { kolaylaştırma }\end{array}$ & $\mathbf{3 , 3} \sqrt{ }$ & 3,1 \\
\hline Yorumlar/kanıtlar/karşılaştırma & $2,9 \sqrt{ }$ & 2,6 \\
\hline $\begin{array}{l}\text { Satın almadan önceki ürün hk. } \\
\text { düşünce }\end{array}$ & $\mathbf{3 , 5} \sqrt{ }$ & 3,1 \\
\hline $\begin{array}{l}\text { Satın almadan önceki reklam } \\
\text { hk. düşünce }\end{array}$ & $3,0 \sqrt{ }$ & 2,7 \\
\hline $\begin{array}{l}\text { Hangi saatler arasında tv } \\
\text { izlersiniz? }\end{array}$ & 3,8 & $4,3 \sqrt{ }$ \\
\hline
\end{tabular}


Infomercial reklamlardan şimdiye kadar satın alanlar ile almayanlar demografik açıdan; cinsiyet, yaş, çocuk sayısı, aylık gelir ve haneye giren aylık toplam gelir ile en son mezun oldukları okul düzeyleri arasında bir farklılık görülmemiştir.

Buna rağmen infomercial reklamlardan alışveriş edenler, alışveriş etmeyenlere göre, gelecekte satın alma niyetine sahip; önümüzdeki 1 hafta içerisinde, 1 ay içerisinde veya 1 yıl içerisinde tekrar satın almayı düşünen ve infomercial reklamlardan satın aldıkları ürünü arkadaşlarına ve ailelerine tavsiye etmeyi düşünen kişilerdir.

Infomercial reklamlardan alı̧̧veriş edenler, alışveriş etmeyenlere göre, infomercial reklama yönelik genel tutumları pozitif olan kişilerdir. $\mathrm{Bu}$ kişilerin infomercial reklamın dikkatlerini çektiği, reklamı izlemeyi sevdikleri ve reklama güvendikleri görülmektedir.

Yine Infomercial reklamlardan alışveriş edenler, alışveriş etmeyenlere göre, infomercial reklamı eğlendirici ve bilgilendirici olarak algıladıkları, alışveriş etmeyenlerin ise alışveriş edenlere göre infomercial reklamı daha aldatıcı olarak algıladıkları görülmüştür.

Infomercial reklamlardan alışveriş edenler, alışveriş etmeyenlere göre, infomercial reklamda yer alan ödeme şekli ve hayatı kolaylaştırma, yorumlar-kanıtlar ve karşılaştırma, satın almadan önceki ürün hakkında düşünce ve satın almadan önceki reklam hakkındaki düşünceye sahip oldukları görülmektedir.

$\mathrm{Bu}$ bağlamda incelendiğinde, infomercial reklamlardan alışveriş edenler, ödeme şekli ve hayatı kolaylaştırma faktörü kapsamında incelendiğinde alışveriş etmeyenlere göre, infomercial reklamda telefon numarası ve internet adresi verilmesinden, ayrıca infomercial reklamlardan satın aldıkları ürünlerin kargo ile eve teslim edilmesi, zamandan tasarruf ederek evden alışveriş yapma kolaylığı sağlaması nedenlerinin satın alma kararında etkili olduğunu ifade etmektedirler.

Infomercial reklamlardan alışveriş edenler, yorumlar, kanıtlar ve karşılaştırma faktörü kapsamında incelendiğinde alışveriş etmeyenlere göre, infomercial reklamda yer alan memnun kullanıcı yorumları, uzman yorumları, sunucu yorumları, infomercial reklamlarda rol alan ünlüler, ürünün yanında verilen ek ürünler/bonuslar ve infomercial reklamda satılan ürünün farklı işlevlerdeki tek bir ürün olmasının satın alma kararında etkili olduğu belirlenmiştir. 
Infomercial reklamlardan alışveriş edenler, satın almadan önceki reklam hakkındaki düşünce faktörü kapsamında incelendiğinde alışveriş etmeyenlere göre, infomercial reklamın; ürün hakkında, ürünü neden satın alınması gerektiği konusunda, ürünün fayda sağlayıp sağlamayacağı hakkında düşünmelerini sağladığı belirlenmiştir.

Infomercial reklamlardan alışveriş edenler, satın almadan önceki ürün hakkındaki düşünce faktörü kapsamında incelendiğinde alışveriş etmeyenlere göre, bir ürünün diğer ürünlerle benzerliğine infomercial reklamlardan baktıkları, infomercial reklamda gördüğünde o ürüne ihtiyaç duyduğu ve ürünü satın almadan önce infomercial reklam hakkında düşündüğ̈̈ görülmektedir.

Yapılan analiz sonucunda infomercial reklamlardan alışveriş etmeyenlerin, alışveriş edenlere göre, televizyon izleme alışkanlıkları açısından farklı alışkanlıklara sahip oldukları belirlenmiştir. $\mathrm{Bu}$ bağlamda incelendiğinde hayır yanıtını veren 300 kişinin \%48'lik kesiminin 20.01-23.00 saatleri arasında televizyon izledikleri belirlenmiştir.

Donthu ve Gilliland'ın 1996 yılında yapmış oldukları çalışmada, infomercial reklamlardan alışveriş edenler, etmeyenlere göre "hayatı kolaylaştırma" beklentisinde olan, "marka bilinci” ve "fiyat bilinci”"ne sahip olan, "çeşitlilik arayışı"nda olan, “düşüncesizce alışveriş eden”, daha "yenilikçi”" olan kişilerdir. Ayrıca infomercial reklamdan alışveriş edenlerin etmeyenlere göre "doğrudan pazarlamaya" ve "reklama" yönelik tutumları pozitifken "geleneksel alışverişe" yönelik tutumları negatiftir. Doğrudan pazarlamadan alışveriş etmeyenler ise alışveriş edenlere göre, "riskten kaçınmaktadırlar" ve "geleneksel alışverişe yönelik tutumları" ise pozitiftir. Bu çalışmaya göre de demografik açıdan alışveriş edenler ile etmeyenler birbirine benzemektedir.

James ve Cunnigham'ın 1987 yılında yapmış olduğu çalışmaya göre ise infomercial reklamlardan alışveriş edenler, etmeyenlere göre televizyon alışkanlıklarının gece yarısından sonra olduğu görülmektedir. 


\section{SONUÇ}

Hızlı geri dönüşüm, kolay ölçülebilme ve kişiselleştirilebilme özelliklerinin yanı sıra etkileşimli olma özelliğini de bünyesinde bulunduran doğrudan pazarlama, günümüzde pazarlamacılar tarafından tercih edilen bir yöntem halini almıştır. Her seferinde yeni müşteri kazanma çabaları maliyetli ve zorludur. Var olan müşteriye satış yapmak ise daha kolay ve de karlıdır. Doğrudan pazarlama yapabilmek için ise güvenilir bilgilere sahip olan güncel bir veri tabanına ihtiyaç vardır. Kitlesel üretimden ve sunumdan sıkılan, diğerlerinden farklı olmak isteyen tüketicinin özelliklerine göre yapılan bir doğrudan pazarlama faaliyeti uzun süreli müşteri sahibi olmaya yarayacak ve firmayı kara götürecektir.

Çağdaş iş yaşamında, zamandan tasarruf etmek isteyen kişilerin özellikle tercih ettiği doğrudan pazarlama yönteminin gelişmesinde, dağıtım kanallarının çeşitlenmesi ve gelişmesi de bir faktör olarak karşımıza çıkmaktadır. Televizyon, internet, telefon gibi çeşitli yollarla sağlanan siparişin eve teslim edilişi tüketiciye kolaylıklar sağlayarak, tüketiciyi bu alışveriş çeşidine yönlendirmektedir.

Doğrudan pazarlama, online pazarlama, yeni dijital pazarlama, telefon ile pazarlama, doğrudan posta, katalogla pazarlama, kiosk ile pazarlama ve doğrudan tepki televizyon pazarlaması gibi iletişim şekillerine sahip olan doğrudan pazarlamanın son yıllarda hızla yükselen şekli doğrudan tepki televizyon pazarlamasıdır. Homeshopping kanalları ile infomercial reklam olmak üzere iki şekilde karşımıza çıkmaktadır. Geleneksel kuşak reklamlarından daha uzun süreli yayınlanan infomercial reklamın özellikle ABD’de popülaritesi hızla yükselmektedir. Ülkemizde de son yıllarda artan teknolojik ilerlemelere paralel olarak, televizyon ve radyo kanallarının çeşitlenmesiyle televizyon izleyicisi demografik özelliklerine göre dilimlenmiştir. Bu bağlamda incelendiğinde infomercial reklam aracılığıyla satış yapabilmenin yolu tüketici davranışını ve tüketici satın alma karar sürecini bilmekten geçer.

Amerika'da infomercial reklamların popülaritesinin bu kadar fazla, ülkemizde ise bu kadar az olmasının nedenini, yaptığımız çalışmadan elde ettiğimiz haneye giren aylık oran ile açıklayabilmemiz mümkündür. Katılımcıların \%40'ndan fazlasının hanesine 2000 TL'den az bir aylık girdiği görülmektedir. Bu nedenle tüketiciler, daha ucuza ürün bulabilmenin hesabını tutmaktadırlar. Genellikle innovative bir ürünle karşımıza çıkan infomercial reklamlar, tüketiciye pahalı gelmekte, bu nedenle daha 
ucuza bulabildiğini, varsa taklidini tercih etmektedir. Gelir yükseldikçe ise risk alma oranın arttığı görülmektedir. Yine doğrudan pazarlamanın bütünü açısından değerlendirildiğinde, bu konuda geride olduğumuz, literatürde yapılan diğer çalışmalarla da desteklenmektedir. Çünkü alışveriş alışkanlıkları da henüz bu tarzda şekillenememiştir. Çalışmayı yaparken görüşülen sektördeki yöneticilerinde belirttiği üzere, 1990'lı yılların başında ilk olarak kanal6'da başlayan televizyon alışveriş sisteminin, hatalar sonucunda, güven duygusunu azaltması, bu tarz alışverişin "dolandırıcılık" olarak adlandırılmasına sebebiyet vermiştir.

Buna rağmen son yıllarda infomercial reklamların sunduğu avantajlar nedeniyle daha çok tercih edilmeye başlamıştır. Çünkü infomercial reklamlar, firmalara ürün ve hizmetlerinin özelliklerini daha iyi anlatma, tüketicisini bilgilendirme ve bir yandan da eğlendirme ve eğitme avantajı sağlarken, geleneksel televizyon reklamı gibi, onlarcasının arasında kaybolup gitmemektedir. İçerikleriyle ve sunumlarıyla daha fazla dikkat çekmekte, ayrıca daha ucuza mal olmaktadırlar. Anında tepki alınabilmesini sağlaması da, satış geliştirme açısından son derece yararlı olabilmektedir.

Infomercial reklamlardan alışveriş edenlerin profilini incelediğimizde, gündüz saatlerinde televizyon izleyen kişiler olduğu karşımıza çıkmaktadır. Bu profildeki tüketicilerin infomercial reklam dikkatini çekmekte, reklamı eğlendirici ve bilgilendirici bulmaktadırlar. Satın almadan önce ürün/hizmet hakkında düşünmesini sağladığı için ve ürünlerin yararlarının tek bir reklamda karşılaştırılmasının sağladığı için infomercial reklamı tercih eden tüketici, özellikle telefon numarası verilmesinden ve reklamdaki memnun tüketicilerin yorumlarından da etkilenmektedir.

Her geçen gün ilerleyen teknoloji sayesinde, televizyonda tıpkı internette olduğu gibi, bir katalogdaki ürüne, kumandadan tek tuşla üzerine gelinip, ürün tanıtımının izlendiği, hatta bir kod yardımıyla satın alınabildiği bir döneme girileceği öngörülmektedir. Bu bağlamda infomercial reklam sektöründeki yöneticilerin teknolojik gelişmeleri yakından takip etmesi avantaj olacaktır. Örneğin infomercial reklamda, telefon numarası, internet adresinin yanı sıra, ürüne ait verilen bir ürün kodunun, kumandanın tek bir tuşuna basarak, cep telefonuna sms olarak gönderilmesi, o sms inde tüketici tarafından yanıtlanarak ürün siparişinde bulunulması olası yöntemlerden biridir. 
Infomercial reklam sektöründeki yöneticilerin "aldatıcılık" unsurunu "güven"e dönüştürebilmesi önerilmektedir. Bu bağlamda reklamda muhakkak "memnun tüketici yorumlarının" yer alması izleyicinin güvenini destekleyici bir unsurdur. İzlenebilirliği açısından, gündüz ya da öğlen kuşağında yayınlanan reklamların, gece yarısından sonra yayımlanması önerilmektedir. Ayrıca eğlence unsurunun da reklamlarda daha baskın yer alması reklamın dikkat çekmesi açısından son derece önemlidir. Örneğin yurt dışındaki örnekleri gibi stand up formatında, ülkemizde yayınlanan reklamdan daha uzun olan bir reklam türü tercih edilmesi izleyiciyi reklama yönlendirecektir. Sektör yöneticilerine, telefonla siparişten ya da internetten elde edilen veri tabanın iyi değerlendirilmesi, çapraz satış yapabilme imkânı da tanıyacaktır. 


\section{KAYNAKÇA}

AGEE Tom ve MARTIN Brett A. S. Planned or Impulse Purchases? How to Create Effective Infomercials [Dergi]. - [s.1.] : Journal of Adversiting Research, 2001. - Cilt November/December. - s. 35-41.

AGEE Tom, MARTIN Brett A. S. ve BHIMY Andrew C. Infomercials And Advertising Effectiveness: An Empirical Study [Dergi]. - [s.1.] : Journal of Consumer Marketing, 2002. - 6 : Cilt 19. - s. 468-480.

AKAT Ömer Uluslararası Pazarlama Karması ve Yönetimi [Kitap]. - Bursa : Ekin Kitapevi, 2001.

AKIN Murat Günümüzde Kullanılan Nihai Tüketicinin Satın Alma Davranış Modelleri [Dergi]. - [s.1.] : Pazarlama Dünyası, 2003. - 8.

ALL BUSINESS [Çevrimiçi] / dü. HALL Ron. - http://www.allbusiness.com/buyingexiting-businesses/mergers-acquisitions/454710-1.html..

ALTUNIŞIK Remzi ve BAKIRTAŞ Hülya Tüketim Duygularının Satın Alma Davranışı Üzerindeki Etkisi [Dergi]. - Kuşadası : 15. Ulusal Pazarlama Kongresi, 26-29 Ekim 2010. - s. 212-226.

ARGAN Metin Çok Katlı Pazarlama ve Türkiye'de Bir Uygulama // Yayımlanmamış Yüksek Lisans Tezi. - Eskişehir : Anadolu Üniversitesi, Sosyal Bilimler Enstitüsü, 1997. ARSLAN Müge ve PİRTíNi Serdar Uluslararası Pazarlamada Tüketici Davranışını Etkileyen Faktörlerden Kültür ve Önemi [Dergi]. - [s.1.] : Pazarlama Dünyası, 2000. 06 : Cilt 14

ASSAEL Henry Consumer Behavior and Marketing Action [Kitap]. - [s.1.] : SouthWestern Pub, 1998. - Cilt 6th.

BALASUBRAMANIAN Siva K. Beyond Advertising and Publicity: Hybrid Messages, Their Effectiveness, and Public Policy Issues [Dergi]. - [s.l.] : Journal of Advertising, 1994. - 24. - s. 9-46.

BALASUBRAMANIAN Siva K., SINGH Mandeep ve CHAKRABORTY Goutam

A Comparative Analysis of Three Communication Formats: Advertising, Infomercial, and Direct Experience [Dergi]. - [s.1.] : Journal of Advertising, 2000. - 4 : Cilt 29. - s. $59-74$.

BAUER Connie L. Direct Response Advertising; Forecasting Responses Over Time [Dergi]. - [s.1.] : Journal of Direct Marketing, 1987. - 4 : Cilt 1. - s. 38-49. 
BAYRAKTAR Azra Endüstriyel Pazarlarda Müşteri İlişsileri Yönetim Stratejilerinin Uygulanması Ve Üretici Firma İle Satış Personeline Duyulan Güven Unsurunun Gelecekteki Satın Alma Kararına Olan Etkilerinin Açıklanmasına Yönelik Yapı Sektöründe Bir Uygulama // Doktora Tezi. - İstanbul : Marmara Üniversitesi İşletme, 2004.

BAYRAKTAR Azra ve ERDEM Şakir Müşterinin Yaşam Boyu Değeri [Kitap Bölümü] // Benim Maaşımı Kim Ödüyor? MÜŞTERİ / yazan GÜRDAL Sahavet. İstanbul : Yaprak Yayın Dağıtım, 2009. - Cilt 1.

BAYRAKTAR Meltem Tüketici Kararlarının Psikolojik Boyutları [Dergi]. - [s.l.] : Ekonomide Ankara, 1989. - 25. - s. 34-37.

BAYSAL Aşkın Doğrudan Pazarlamanın Kurucusu: Lestern Wunderman [Kitap]. İstanbul : MediaCat Yayınları, 2006. - İz Bırakanlar Serisi 8.

BELCH George ve BRODOWSKY Glen H As Seen On TV And Now in a Marketing Classroom Near You: The Infomercial [Dergi]. - [s.1.] : Marketing Education Review, 2006. - 1 : Cilt 16. - s. 23-27.

BERKMAN W. Harold ve GILSON Christopher Consumer Behaviour: Concepts and Strategies [Kitap]. - Boston : Kent Publishing Co,, 1986. - Cilt 3.Bask1.

BERKMAN W. Harold ve GILSON Christopher Consumer Behaviour: Concepts and Strategies [Kitap]. - Boston : Kent Publishing Company, A Division of Wadsworth, Inc, 1992. - Cilt Third Edition.

BIRD Drayton Commensense Direct Marketing [Dergi]. - [s.l.] : NTC Business Boks, 1989.

BLYTHE Jim Essentials of Marketing [Kitap]. - [s.1.] : Pearson Education Limited, 2001. - Cilt 2.

BODUR H.Onur, BRINBERG David ve COUPEY Eloise Belief, Affect and Attitude: Alternative Models of The Determinants of Attitude [Dergi]. - [s.1.] : Journal of Consumer Psychology, 2000. - 1 : Cilt 9. - s. 17-28.

BOGART Leo The Multiple Meanings of Television Advertising [Dergi]. - [s.1.] : Television Advertising, 1988. - s. 76-80.

BOSSHART Louis ve MACCONI Illaria Media Entertainment [Dergi]. - [s.1.] : Communication Research Trends, 1998. - 3 : Cilt 18. - s. 1-48.

BUSH Alan J. ve BUSH Robert P. A Content Analysis of Direct Response Television Advertising [Dergi]. - [s.1.] : Journal of Direct Marketing,, 1990. - 1 : Cilt 4. - s. 6-13. 
BUSH S.Paul ve HOUSTON J.Michael Marketing: Strategic Foundations [Kitap]. [s.1.] : Illinois: Richard D. Irwin Inc., 1985. - Cilt 1.

CEREYAN MEDYA [Çevrimiçi]// RTÜRK IZLENME ORANLARI. http://www.cereyan.com.tr/.

CERITTOĞLU Bahar ve SCHNEIDER Gülpınar Kelemci İnterette Ağızda Ağıza İletişim Platformlarının Farklı Ürün Gruplarındaki Satın Alma Eğilimi Üzerinedeki Etkilerinin Ölçümlenmesine İlişkin Bir Araştırma [Dergi]. - Kuşadası : 15. Ulusal Pazarlama Kongresi, 2010. - s. 344-354.

CHAPMAN Patrica ve BELTRAMINI Richard F. Infomercial Revisited: Perspectives of Advertising Professionals [Dergi]. - [s.1.] : Journal of Advertising Research, 2000. - Cilt September.October. - s. 24-30.

CÖMERT Yavuz Doğrudan Pazarlama ve Türkiye Uygulamaları: Yayıncılık Sektörü Örneği, // Yayınlanmamış Doktora Tezi. - İzmir : Dokuz Eylül Üniversitesi, SBE, 1989.

ÇAKIR VESÍLE ve ÇAKIR VEDAT Televizyon Reklamlarının Algılanan Değeri ve Reklam Tutumu İlişkisi: Bir Yapısal Eşitlik Modeli [Dergi]. - [s.l.] : İstanbul Üniversitesi İletişim Fakültesi Dergisi, 2007. - Cilt 30. - s. 37-59.

Çok Katlı Pazarlamaya İlişkin Öğrenmek İstediğiniz Bütün Temel Bilgiler [Çevrimiçi]. - http://www.angelfire.com/dc/paratreni/.

DANAHER Peter J. ve GREEN Benjamin J. A Comparison of Media Factors that Influence the Effectiveness of Direct Response Television Advertising [Dergi]. - [s.1.] : Journal Of Direct Marketing, 1997. - 2 : Cilt 11. - s. 46-58.

DENİ R. Baki Yeni Bir Pazarlama Yöntemi Olarak Elektronik Posta Pazarlaması [Dergi]. - [s.1.] : Jounal of İstanbul Kültür Univesity, 2002. - Cilt 2. - s. 1-10.

Direct Marketing Associasion (DMA) What is the Direct Marketing Associasion ? [Çevrimiçi]. - HAZİRAN 2010. - http://www.thedma.org/aboutdma/whatisthedmas.html.

Doğrudan Pazarlama [Çevrimiçi]/ dü. MENTEŞOĞLU Alper. - NISSAN 2010. http://www.bpi.somee.com/haber_detay.asp?haberID=94.

Doğrudan Pazarlama İletişimcileri Derneği Sektör - Faaliyet Alanı [Çevrimiçi]. http://www.dpid.org.tr/v2/content2.asp?id=8.

Doğrudan Satış Derneği (DSD) Avrupa'da Doğrudan Satış [Çevrimiçi]. - 2010. http://www.dsd.org.tr/sektorHakkinda.asp.

DONTHU Naveen ve GILLILAND David Observations: The Infomercial Shopper [Dergi]. - [s.1.] : Journal of Advertising Research, 1996. - Cilt March/April. - s. 69-76. 
DUCOFFE Robert H. How Consumers Assess the Value of Advertising [Dergi]. [s.1.] : Journal of Current Issues and Research in Advertising, 1995. - 1 : Cilt 17. - s. 118.

DUNCAN Tom IMC Using Advertising and Promotion to Building Brands [Kitap]. [s.1.] : McGraw-Hill-Irwin, 2001.

DÜNYA PAZARLAMA [Çevrimiçi]. - 2011. - NISAN 2011. http://www.dunyapazarlama.com.

ELDEN Müge, ULUKÖK Özkan ve YAYGEL Sinem Şimdi Reklamlar [Kitap]. İstanbul : İletişim Yayınları, 2005. - Cilt 1.

ELLEN Benremer Top Telemarketing Techniques [Dergi]. - [s.1.] : Career Press, 2003. ELLIOTT Michael T ve LOCKARD Pamela An Analysis of Information Content in Infomercial Programs [Dergi]. - [s.1.] : Journal of Direct Marketing, 1996. - 2 : Cilt 10. s. $44-56$.

ERDEM Şakir Satış Geliştirme Faaliyetlerinin Müşteri Davranışları Üzerine Etkisi [Kitap]. - İstanbul : Beta Basım Yayın, 2010. - Cilt 1. Bask1.

ERP Akademi [Çevrimiçi] // REFERANS GRUPLARI. - NISAN 2011. http://www.erpakademi.com/2009/12/06/referans-gruplari/.

ERP Akademi [Çevrimiçi]// Dükkansız Perakendecilik. - 2010. http://www.erpakademi.com/2009/12/05/dukkansiz-perakendecilik.

FAIRCHILD Paula Hawthorne Direct is a Leader in the Latest Development in LongForm Advertising [Dergi]. - [s.1.] : Business, 1998.

Focus Kiosk [Çevrimiçi]. - 2010. - http://www.focusturk.com/kiosk.htm.

FRANZEN Giep Reklamın Marka Değerine Etkisi [Kitap]. - [s.1.] : Mediacat, 2005.

GEGEZ Ercan Pazarlama Araştırmaları [Kitap]. - İstanbul : Beta Yayınları, 2005.

GELLER K.Lois Çev:Osman Cem Onartoy Karlı Doğrudan Pazarlama [Kitap]. İstanbul : Sistem Yayınc1lık, 2004.

Gonca Grubu Kiosk [Çevrimiçi]. - http://www.mesci.net/demo/gonca/default.asp.

GÜRAĞAÇ Nihal Doğrudan Pazarlama Yönelimlerinden Çok Katlı Pazarlama // Yayınlanmamış Yüksek Lisans Tezi. - Kütahya : Dumlupınar Üniversitesi, 2006.

HASPOLAT Turgut Elektonik Ticaret [Kitap]. - [s.l.] : Medya Yayınları, 1998. - Cilt Eylül.

HAŞILOĞLU Selçuk Burak Elektronik Posta ile Pazarlama Üzerine Bir Araştırma [Dergi]. - [s.1.] : İnternet Uygulamaları ve Yönetimi Dergisi, 2010. - 1 : Cilt 1. - s. 61-70. 
HATÍBOĞLU Zeyyat TEMEL PAZARLAMA [Kitap]. - İstanbul : Beta Yayınları, 1993. - Cilt 11.

HER EVE LAZIM [Çevrimiçi]. - 2011. - http://www.herevelazim.com.tr.

HETSRONI Amir ve ASYA Ilan A Comrasion of Values in Infomercials And Commercial [Dergi]. - [s.l.] : Corporate Communication: An International Journal, 2002. - 1 : Cilt 7.

HOLLOWAY Robert J. MITTSTEAD Robert A. ve VENKATESAN M. Consumer Behavior: Contemporary Research in Action [Kitap]. - Boston : Houghton Mifflin Co., 1971.

INCEOĞLU Metin Tutum-Algı-İletişim [Kitap]. - Ankara : İmaj Yayıncılık, 2000. Cilt 3.

JAMES E. Lincoln ve BERGH Bruce G. Vanden An Information Content Comparison of Magazine Ads Across a Response Continuum from Direct Response to Institutional Advertising [Dergi]. - [s.1.] : Journal of Advertising, 1990. - 2 : Cilt 19. - s. 23-29.

JAMES E. Lincoln ve BERGH Bruce G. Vanden On the Information Content of Advertising "General" Versus Direct Response Magazine Advertisements [Dergi]. [s.1.] : Journal of Direct Marketing, 1989. - 3 : Cilt 3. - s. 7-14.

JAMES E. Lincoln ve CUNNINGHAM Isabella C. M. A profile of Direct Marketing Television Shoppers [Dergi]. - [s.1.] : Journal of Direct Marketing, 1987. - 4 : Cilt 1. - s. 12-23.

JOBBER David Principles and Practice of Marketing [Dergi]. - London : McGraw-Hill Publishing Co., 1998.

KABADAYI Ebru Tümer, ALNIAÇIK Ümit ve DURSUN İnci Tüketici Karar Verme Tarzları Ölçeği: Türk Tüketicisi için Uyarlama [Dergi]. - Kuşadası : 15. Ulusal Pazarlama Kongresi, 2010. - s. 321-326.

KARABULUT Muhittin Tüketici Davranışı [Kitap]. - İstanbul : İ.Ü. İşletme İktisadi Enstitüsü, 1989. - Cilt Genişletilmiş 3.Baskı.

KARAFAKİOĞLU Mehmet Pazarlama İlkeleri [Kitap]. - İstanbul : Literatür Yayınları, 2006.

KARALAR Rıdvan Çağdaş Tüketici Davranışı [Kitap]. - Eskişehir : Birlik Yayıncılık., 2005.

KARTAL Esen Deniz Doğrudan Posta Yönteminde Müşterilerin Geri Kazanımları İle Demografik, Sosyo Ekonomik Özellikleri Arasındaki İlgi Ve Yönteme İlişkin 
Değerlemeleri // Yayınlanmamış Yüksek Lisans Tezi. - İstanbul : İstanbul Üniversitesi, 2007.

Katalogla Pazarlama Pazarlama Yönetimi [Çevrimiçi]/ dü. ESENKAL Yusuf. 2010. - http://www.pazarlamayonetimi.com/?p=327.

KAYAR İsmail Pazarlama Bi Tanedir. Bir Pazarlama Ansiklopedisi [Kitap]. - [s.l.] : Babıali Yayıncılık, 2010.

KEEGAN W.J. ve GREEN M.C Global Marketing [Kitap]. - [s.1.] : Pearson Education International, 2008. - Cilt 5. Edition.

KEMPF DeAnna S. Attitude Formation from Product Trial: Distinct Roles of Cognition and Affect for Hedonic and Functional Products [Dergi]. - [s.1.] : Psychology and Marketing, 1999. - 1 : Cilt 16. - s. 35-50.

KILIÇ Sabiha ve GÖKSEL Aykut Tüketici Davranışları: İndirimli Kartların Tüketici Satın Alma Karar Süreci Üzerindeki Etkisine Dair Ampirik Çalışma [Dergi]. - [s.1.] : Standart TSE Dergisi, 2004.

KOCABAŞ Füsun Pazarlamada Yeni Yaklaşımlar Ve Reklam [Kitap]. - [s.l.] : Dönence Yayınları, 2005.

KOÇKAYA Figen Arslan Doğrudan Pazarlama Aracı Kiosklar Ve Tüketiciler Tarafından Kullanım Etkinliği Kayseri De Kiosk Kullanan İşyerleri Üzerine Bir Uygulama // Yayınlanmamış Yüksek Lisans Tezi. - Sivas : Cumhuriyet Üniversitesi SBE, 2006.

KOTLER Philip Marketing Management [Kitap]. - New Jersey : Prentice Hall, 2000. Cilt 10 .

KOTLER Philip Pazarlama Yönetimi [Kitap]. - İstanbul : Beta Basım Yayım, 2000.

KOTLER Philip ve AMSTRONG Gary Principles of Marketing [Kitap]. - [s.1.] : Prentice Hall College Div, 2005. - Cilt 11th. Edition.

KOTLER Philip ve AMSTRONG Gary Principles of Marketing [Kitap]. - [s.1.] : Prentice Hall, 2008. - Cilt 12.

KOTLER Philip ve AMSTRONG Gary Principles of Marketing, [Kitap]. - [s.1.] : Prentice Hall College Div, 1996. - Cilt 7th Edition.

KURTULUŞ Kemal Pazarlama Araştırmaları [Kitap]. - İstanbul : Literatür Yayıncılık, 2004.

KURTULUŞ Kemal Pazarlama Araştırmaları [Kitap]. - İstanbul : Avcıol Basım Yayın, 1998. 
KURTULUŞ Sema, YENİÇERİ Tülay ve YARAŞ Eyüp Perakendeci Markalı Ürün Satın Alan Bayan Tüketicilere İlişkin Alt Pazar Bölümlerinin Oluşturulması Üzerine Bir Pilot Araştırma [Dergi]. - İstanbul : İstanbul Üniversitesi İşletme Fakültesi Dergisi, 2001. - 1 : Cilt 30. - s. 51-67.

LAMB W. Charles , HAIR F. Joseph ve McDaniel Carl Principles of Marketing [Kitap]. - Ohio : South-Western Publishing Co., 1994. - Cilt 2.Bask1.

LAZER William ve LAYTON Roger Marketing of Hospitality Services [Kitap]. Michigan : AHMA Educational Services, 1999.

LEBOURVEAU Carol A., DWYER F. Robert ve KERNAN Jerome B. Compliance Strategies in Direct Response Advertising [Dergi]. - [s.1.] : Journal of Direct Marketing, 1988. - 3 : Cilt 2. - s. 25-34.

LOUDON L.David ve BITTA J.Albert Della Consumer Behaviour: Concepts and Applications [Kitap]. - New York : McGraw Hill Book Com, 1988. - Cilt 3.Bask1.

MacKENZIE Scott B., LUTZ Richard J. ve BELCH George E. The Role of Attitude Toward the Ad as a Mediator of Advertising Effectiveness: A Test of Competing Explanations [Dergi]. - [s.1.] : Journal of Marketing Research, Mayıs 1986. - 2 : Cilt 23. - s. 130-143.

MacKENZIE Scott ve LUTZ Richard J. An Empirical Examination of the Structural Antecedents of Attitude Toward the Ad in an Advertising Pretesting Context [Dergi]. [s.1.] : Journal of Marketing, Nisan 1989. - 2 : Cilt 53. - s. 48-65.

MacKEZIE Scott B., LUTZ Richard J. ve BELCH George E. Attitude Toward The Ad As A Mediator Of Advertising Effectiveness: Determinants And Consequences [Dergi] / dü. Bagozzi Richard P. ve Tybout Alice M. . - [s.l.] : Advances in Consumer Research 10, Ann Arbor: Association for Consumer Research, 1983. - s. 532-539.

MC KENNA Regis Real Time Marketing [Dergi]. - [s.l.] : Harvard Business Review, 1995. - July-August : Cilt 73. - s. 87-95.

McCORKELL Graeme Direct and Database Marketing [Kitap]. - London: The Institute of Direct Marketing, 1997.

McDonald William J. Direct Marketing An Integrated Approach [Kitap]. - [s.1.] : Mc Graw-Hill, 1997. - Cilt Higher Education.

MICROSOFT Shopping TV [Çevrimiçi]. - Nisan 2010. http://www.microsoft.com/turkiye/casestudies/dynamics/shoppingtv.mspx. 
MITTIAL PURCHASE DECISION INVOLVEMENT [Kitap Bölümü] // HANDBOOK OF MARKETING SCALES / yazan BEARDEN William O. ve NETEMEYER Richard G.. - 1989.

MOLTES William M., HILTON Chadwick B. ve FIELDEN John S. Reaction of Creative Variation of a Direct Response Ad [Dergi]. - [s.1.] : Journal of Direct Marketing, 1989. - 3 : Cilt 3. - s. 16-26.

MUCUK İsmet Pazarlama İlkeleri [Kitap]. - İstanbul : Türkmen Kitabevi, 2001. - Cilt Genişletilmiş 13.Baskı.

NAMATOVA Gülmira ve ÖZDEMİR Ali Ürün Pazarlamasında Doğrudan Pazarlama Anlayışının Gelişme Potansiyelini Etkileyen Değişkenler: İzmir İlinde Yaşayan Tüketiciler Üzerinde Uygulama [Dergi]. - İzmir : Dokuz Eylül Üniversitesi, Sosyal Bilimler Enstitüsü Dergisi, 2007. - 1 : Cilt 9. - s. 360-372.

NASH Edward L Direct Marketing: Strategy, Planning, Execution [Kitap]. - New York : McGraw Hill, 1982.

NOVICK Harold J. Satış Organizasyonları [Kitap]. - İstanbul : Rota Yayın, 1988.

NOYAN Fatma Çok Aşamalı Yapısal Eşitlik Modellerinin İş Tatmini ile Örgütsel Bağlılık Arasındaki İlişki Üzerine Bir Uygulaması // Doktora Tezi. - İstanbul : Marmara Üniversitesi Sayısal Yöntemler Bilim Dalı, 2009.

ODABAŞI Yavuz Müşteri Ne istiyorsa Onu verin; Sonra Sıra Size Gelince... [Dergi]. [s.1.] : Sabah Business, 2004. - Cilt 21. - s. 6-7.

ODABAŞI Yavuz Pazarlama İletişimi [Kitap]. - Eskişehir : Anadolu Üniversitesi İşletme Fakültesi, 1995. - Cilt 1.

ODABAŞI Yavuz Tüketici Davranışı ve Pazarlama Stratejisi, [Dergi]. - Eskişseihir, : Anadolu Üniversitesi İşletme Fakültesi, 1996. - 2.

ODABAŞI Yavuz ve OYMAN Mine Pazarlama İletişimi Yönetimi [Kitap]. Eskişehir : MediaCat, 2002. - Cilt 7.Baskı.

ÖNCÜ Fatih E Pazarlama-İnternet Olanaklarıla Ürün Ve Hizmetin Hedef Pazara Sunulması Ve Satışı [Kitap]. - [s.1.] : Literatür Yayıncılık, 2002,. - Cilt EYLÜL.

ÖZDEMİRCi Ata Strateji Sürecinin Planlılık Düzeyi, Liderlik Stilleri Ve Çevresel Koşulların Örgütsel Uyumlanma Üzerindeki Etkisi: İso’ya Bağlı İşletmeler Üzerinde Bir Araştırma // Doktora Tezi. - İstanbul : Marmara Üniversitesi Yönetim ve Organizasyon Bilim Dalı, 2010.

ÖZDEN Leyla Algılama: Tüketici Davranışı İçindeki Yeri ve Pazarlamadaki Önemi [Dergi]. - [s.1.] : Pazarlama Dergisi, 1978. - 34. 
ÖZER Nur Algılama ve Pazarlama Uygulamaları [Dergi]. - [s.l.] : PARADOKS, Ekonomi, Sosyoloji ve Politika Dergisi((e-dergi), http://www.paradoks.org), 2009. - 1 : Cilt 5.

ÖZMORALI Hakkı MARKETING TÜRKIYE [Çevrimiçi]// Bir "Doğrudan Satış Ülkesi” Olmaya Doğru.... - 2010. - http://www.marketingturkiye.com.

PELTEKOĞLU Filiz Balta Halkla İlişkiler Nedir? [Kitap]. - [s.l.] : Beta Yayınları, 2001.

PELTEKOĞLU Filiz Balta Kavram ve Kurallarıyla Reklam [Kitap]. - [s.1.] : Beta Yayınları, 2010. - Cilt Mayıs.

PELTIER James W., MUELLER Barbara ve ROSEN Richard G. Direct Response Versus Image Advertising [Dergi]. - [s.1.] : Journal of Direct Marketing, 1992. - 1 : Cilt 6. - s. 40-48.

PIRNAR İge Doğrudan Pazarlama [Kitap]. - Ankara : Seçkin, 2010. - Cilt 5.

RESNIK Alan ve STERN Bruce L. An Analysis of Information Content in Television Advertising [Dergi]. - [s.1.] : Journal of Marketing, 1977. - Cilt January.

ROBERTS Mary Lou ve BERGER Paul D. Direct Marketing Management [Kitap]. London : Prentice Hall International, 1999. - Cilt II.

SADIKOVA Aygün Tüketicilerin Reklamlara Yönelik Tutumları -Karşılaştırmalı Bir Araştırma- (Türkiye-Rusya) // Yayınlanmamış Yüksek Lisans Tezi. - Kayseri : Erciyes Üniversitesi Sosyal Bilimler Enstitüsü, 2006.

SALOMON Ilan ve KOPPELMAN Frank S. Teleshopping or Going Shopping? An İnformation Acquisition Perspective [Dergi]. - [s.1.]: Behaviour \& Information Technology, 1992. - 4 : Cilt 11. - s. 189-198.

SANAKTEKIN Özlem Hesapçı ve YEŞİLADA Irmak İnternet Üzerinden Alışverişe Karşı Tutumu Etkileyen Psikolojik Faktörler Üzerine Bir Araştırma [Dergi]. - Kuşadası : 15. Ulusal Pazarlama Kongresi, 26-29 Ekim 2010. - s. 637-639.

SCHIFFMAN Leon G. ve KANUK Leslie Lazar Consumer Behavior [Kitap]. - New Jersey : Prentice Hall, 2000. - Cilt 7.

SCHWARTZ J. David Marketing Today: A Basic Approach [Kitap]. - [s.1.] : Harcourt Brace Jovanovich Inc., 1981.

SEITZ Victoria Direct Response Advertising in the US and European Markets: A Content Analysis of Fashion Products [Dergi]. - [s.1.] : European Business Review, 1998. - 5 : Cilt 98. - s. 268-275. 
SHAVITT Sharon, LOWREY Pamela ve HAEFNER James Public Attitudes Towards Advertising: More Favorable Than You Might Think [Dergi]. - [s.1.] : Journal of Advertising Research, 1998. - Cilt July.August. - s. 7-21.

SHETH N. Jagadish The Future of Relationship Marketing [Dergi]. - [s.1.] : Journal of Services Marketing, 2002. - 7 : Cilt 16. - s. 590-592.

SHOPPING TV [Çevrimiçi]. - OCAK 2011. - http://www.shoppingtv.com.

SİPAHI Beril, YURTKORU Serra ve ÇİNKO Murat Sosyal Bilimlerde SPSS'le Veri Analizi [Kitap]. - İstanbul : Beta Basım, 2008. - Cilt 2..

STONE Bob Should Mass Marketing go into Direct Marketing [Dergi]. - USA : Kobs, Illinois, 1992.

STONE Bob ve WHYMAN John Succesfull Telemarketing, [Dergi]. - [s.1.] : NTC, Business Books,, 1992.

STUDIO MODERNA [Çevrimiçi]. - 2011. - OCAK 2011. - http://www.studiomoderna.com/.

ŞİMŞEK Ömer Faruk Yapısal Eşitlik Modellemesine Giriş (Temel İlkeler ve LISREL Uygulamaları) [Kitap]. - Ankara : Ekinoks, 2007.

TAPAN Sema Pazarlama İletişimi [Dergi]. - Eskişehir : Anadolu Üniversitesi İşletme Fakültesi Yayınları, 1997.

TEK Ömer Baybars Pazarlama İlkeleri [Kitap]. - İzmir : Cem Ofset, 1997.

TELE MARKET [Çevrimiçi]. - 2011. - ŞUBAT 2011. - http://www.telemarket.com.tr. TIĞLI Mehmet ve PİRTINİ Serdar Satış Özendirmede Etkili Bir Araç Olarak Insert ve Hiper/Süpermarket Müşterileri Üzerinde Bir Uygulama [Dergi]. - [s.1.] : Sosyal Bilimler Dergisi, 2003. - Cilt 2. - s. 117-143.

TIMMERMANS Harry ve MORGANOSKY Michelle Special Issue on Direct Marketing: Where The Old Meets The New [Dergi]. - [s.1.] : Journal of Business Research, 1999.

TIMMUR Necdet, ÖZTÜRK A. Sevgi ve OYMAN Mine Pazarlama Kanallar1 [Kitap]. Eskişehir : Anadolu Üniversitesi AÖF Yayınları, 1996.

TOKOL Tuncer Pazarlama Yönetimi [Kitap]. - [s.l.] : Bilimsel Araştırma Basım ve Yayın İşletmesi, 1996. - Cilt 7.Basım.

TOPSHOP [Çevrimiçi]. - OCAK 2011. - http://www.topshop.com.tr/.

UYDACI Mert Pazarlamada Elektronik Posta [Dergi]. - İzmir : Ege Akademik Bakış,, 2004. - 1 : Cilt 4. - s. 79-84. 
UZUNOĞLU Ebru Müşteri Odaklı Pazarlama Anlayışına Göre değer Yaratma Bir Model Olarak Değer İletim Sistemi [Dergi]. - Eskişehir : Osmangazi Üniversitesi İİBF Dergisi, 2007. - Cilt 2. - s. 11-29.

Vikepedia Sözlük Infomercial Reklam [Çevrimiçi]// Vikepedia Sözlük. - 2011. ŞUBAT 2011. - http://en.wikipedia.org/wiki/Infomercial.

Vikipedia Sözlük [Çevrimiçi]// Digital Marketing. - Haziran 2011. http://en.wikipedia.org/wiki/Digital_marketing.

VORDERER Peter It's all entertainment-sure. But what exactly is entertainment? Communication research, media psychology, and the explanation of entertainment experiences [Dergi]. - Hannover/Germany : Poetics, November 2001. - 4-5 : Cilt 29. - s. 247-265.

What is com [Çevrimiçi]. - Haziran 2011. http://whatis.techtarget.com/definition/direct-digital-marketing.html.

WICKS Jan LeBlanc ve ABERNETHY Avery M. Effective Consumer Protection or Bening Neglect? A Model of Television Infomercial Clearance [Dergi]. - [s.l.] : Journal of Advertising, 2001. - 1 : Cilt xxx. - s. 41-54.

WICKS Jan LeBlanc ve WARREN Ron An Analysis of Twenty Years of Deceptive Infomercials: Suggestions for Improving Infomercial Self-Regulation [Dergi]. Arkansas : American Academy of Advertising, 2005. - s. 95-105.

WICKS Jan LeBlanc Which Factors Primarily Influence the Number of Infomercial Hours a Commercial Television Airs? [Dergi]. - [s.1.]: The Journal of Media Economics, 1997. - 1 : Cilt 10. - s. 29-38.

WOODSIDE Arch G. ve MOTES William H. Image Versus Direct-Response Advertising [Dergi]. - [s.1.] : Journal of Advertising Research, 1980. - 4 : Cilt 20. - s. 31-38.

YILMAZ Veysel ve ÇELIKK H. Eray LISREL ile Yapısal Eşitlik Modellemesi-I, Temel Kavramlar, Uygulamalar, Programlama, [Kitap]. - [s.l.] : Pegem Akademi, 2009. ZALTMAN Gerald Tüketici Nasıl Düşünür? [Kitap] / çev. KOÇ A.Semih . - İstanbul : MediaCAt, 2004.

ZYMAN Sergio ve MILLER Scott Geleceğin Pazarlaması: Marka Yayılımı Stratejisi [Kitap] / dü. Güçer Cumhur. - İstanbul : Media Cat Kitapları, 2003. 
EKLER 
EK 1:

Sayın Katılımc1,

Bu anket Marmara Üniversitesi Sosyal Bilimler Enstitüsü, Üretim Yönetimi ve Pazarlama Tezli Yüksek Lisans Programı çerçevesinde Özge Subaşı tarafindan yürütülen akademik bir çalışma için veri toplamak amacıyla hazırlanmışıtır.

Cevaplarınız akademik amaçlı olarak titizlikle değerlendirilecek ve kesinlikle üçüncü şahıslar ve kurumlar ile paylaşılmayacaktır.

Zamanınızı ayırıp katkıda bulunduğunuz için çok teşekkür ederiz.

\section{Çalışmayı yapan öğrenci;}

Özge Subaşı

Marmara Üniversitesi

Üretim Yönetimi ve Pazarlama Y.L. Öğrencisi

\section{Tez danışmanı;}

Yrd. Doç. Dr. Azra BAYRAKTAR

Marmara Üniversitesi

Üretim Yönetimi ve Pazarlama

Bilim Dalı 


\section{ANKET}

$\mathrm{Bu}$ anket Marmara Üniversitesi Sosyal Bilimler Enstitüsü, Üretim Yönetimi ve Pazarlama Tezli Yüksek Lisans Programı çerçevesinde yürütülen akademik bir çalışma için veri toplamak amacıyla hazırlanmıştır. Anketin amacı; tanıtıcı (infomercial) reklamların değeri ve bu reklamlardan tüketicinin satın alma davranışlarını etkileyen faktörlerin değerlendirilmesi amacıyla yapılmaktadır.

*Infomercial Reklam: Televizyonda normal reklamlardan daha uzun süre yayınlanan, telefon numarası veya internet adresi verilen, sadece bir tane ürünü satmaya yönelik uzunca tanıtımların yapıldığ 1 , "bir televizyon programı ya da kısa belgesel formatındaki" reklamlar tanıtıcı (infomercial) reklamlar olarak adlandırılır.

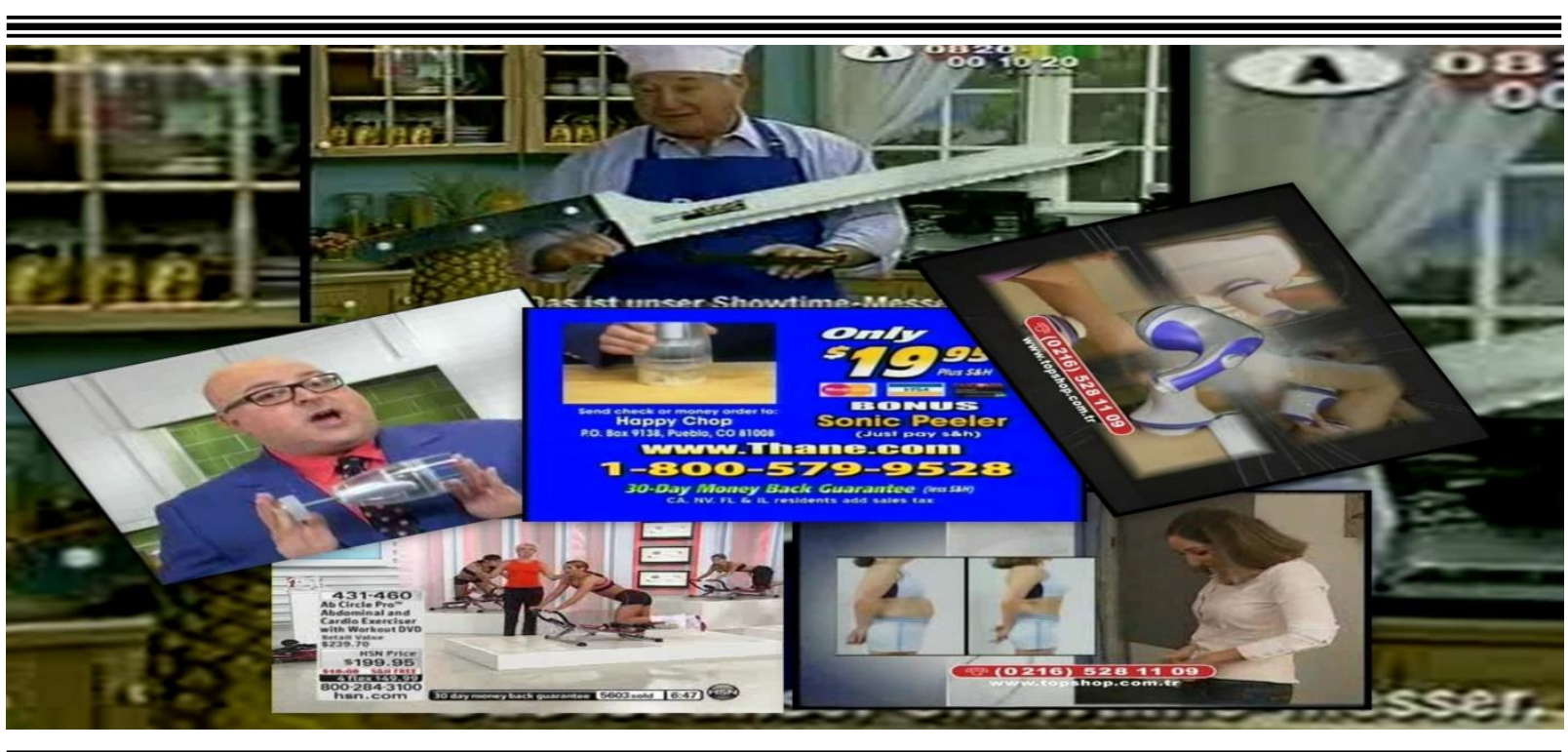

$\mathrm{Bu}$ çalışma kapsamında tanıtıcı (infomercial) reklamların değerinin belirlenmesi ve satın almayı etkileyen faktörler araştırılmaktadır. Lütfen bu açıklamalar ışığında aşağıdaki soruları ölçeği kullanarak yanıtlayınız.

Ölçekte yer alan 1-5 arasındaki değerler ifadeye ne derece katıldığınızı göstermektedir.

\section{Kesinlikle katılmıyorum}

\section{Katılmıyorum}

3 Ne katılıyorum ne katılmıyorum

\section{Katılıyorum}

\section{Kesinlikle katılıyorum}



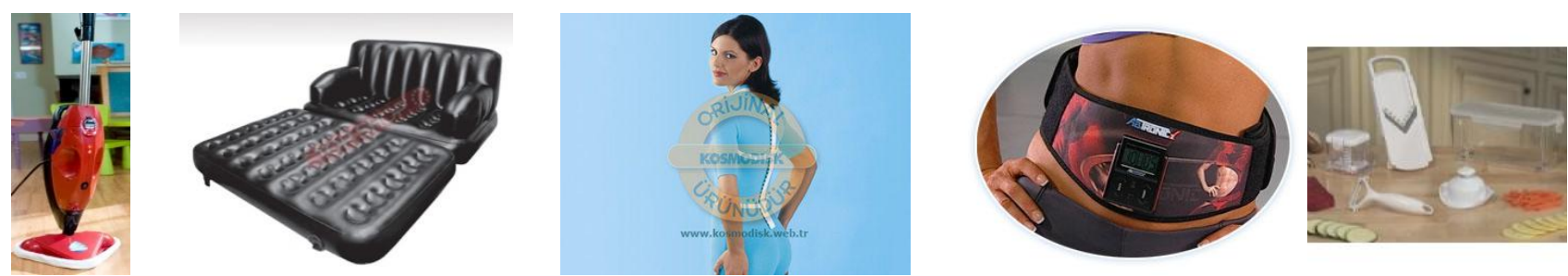

1. Geleneksel kuşak reklamlarından uzun süren, ürünün özelliklerinin ve kullanım şekillerinin bir sunucu veya halktan ürünü deneyen kişi tarafından anlatılan (Kosmodisk Classic omurga masörü, Dr. Levine manyetik dizlik, H2O Buharlı temizleyici gibi) tanıtıcı (infomercial) reklamları izledikten sonra televizyon da verilen numarayı arayarak hiç alışveriş yaptınız mı?

$\ulcorner$ Evet

$Г$ Hayir

2. En çok hangi ürün grubundan alışveriş yaptınız?

Г Egzersiz aletleri (örnek: Circle glide, AB Tronic gibi)

$\lceil$ Mutfak aksesuarlari (örnek: Speed slicer süper hizli dilimleyici, Bullet express mikser seti)

$Г$ Diet programlari (örnek: Acailos Bitkisel zayiflama destegi gibi)

$\ulcorner$ Eglence (örnek: ziplama topu gibi)

$\Gamma$ Saglik (örnek:Dr. Levine manyetik dizlik, Kosmodisk Classic omurga masörü gibi)

$\Gamma$ Güzellik (örnek: Relax and tone masaj ve zayiflama aleti, Slim in lift supreme comfort korse gibi)

$\ulcorner$ Ev gereçleri (örnek: H2O Map Ultra buharli temizleyici gibi)

\section{Haftanın kaç günü televizyon izlersiniz?}

$\Gamma$ Sadece hafta sonu

$\ulcorner$ Hafta içi her gün

$\Gamma$ Hafta içi bazi günler

Г Hafta içi ve hafta sonu genellikle izlerim

\section{Hangi saatler arasında TV izlersiniz?}

$\Gamma 06.00-10.00 \quad \Gamma 10.01-12.00 \quad \Gamma 12.01-19.00 \quad \Gamma 19.01-20.00$
$\ulcorner 20.01-23.00$




\begin{tabular}{|c|c|c|c|c|c|}
\hline $\begin{array}{l}\text { 5. Aşağıdaki soruları tanıtıcı (infomercial) reklama yönelik } \\
\text { tutumlarınızı değerlendirerek kesinlikle katılmıyorum- } \\
\text { katılmıyorum-ne katılıyorum ne katılmıyorum- katılıyorum- } \\
\text { kesinlikle katılıyorum şeklinde cevaplandırınız. }\end{array}$ & 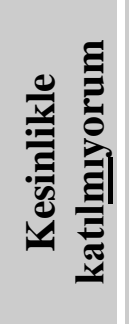 & 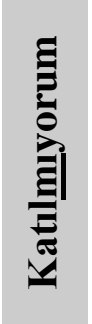 & 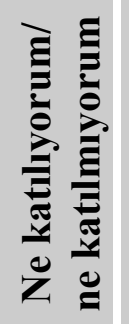 & ב气 & 焉 \\
\hline Genelde tanitıc1(infomercial) reklamları izlemeyi severim & $\sqsubset$ & $\sqsubset$ & $\sqsubset$ & $\sqsubset$ & $\sqsubset$ \\
\hline Genelde tanıtıcı (infomercial) reklamlar dikkatimi çekmez & $\sqsubset$ & $\sqsubset$ & $\sqsubset$ & $\sqsubset$ & $\sqsubset$ \\
\hline Genelde tanitıc1 (infomercial) reklamlara güvenirim. & $\sqsubset$ & $\sqsubset$ & $\sqsubset$ & $\sqsubset$ & $\sqsubset$ \\
\hline Tanıtıcı (infomercial) reklamlar ürünle ilgili bilgi sağlar. & $\sqsubset$ & $\sqsubset$ & $\sqsubset$ & $\sqsubset$ & $\sqsubset$ \\
\hline Tanıtıcı (infomercial) reklamlar ürün ile ilgili güncel bilgi verir. & $\sqsubset$ & $\sqsubset$ & $ᄃ$ & $\sqsubset$ & $\sqsubset$ \\
\hline $\begin{array}{l}\text { Tanıtıcı (infomercial) reklamlar ürünle ilgili bilgiyi, insanlar ürünler } \\
\text { hakkında bilgiye ihtiyaç duydukları zaman verir. }\end{array}$ & $\sqsubset$ & $\sqsubset$ & $\sqsubset$ & $\sqsubset$ & $\sqsubset$ \\
\hline Tanitıci (infomercial) reklamlar aldatıcidır. & $\sqsubset$ & $\sqsubset$ & $\sqsubset$ & $\sqsubset$ & $\sqsubset$ \\
\hline Tanitıcı (infomercial) reklamlar yalan söyler. & $\sqsubset$ & $\sqsubset$ & $\sqsubset$ & $\sqsubset$ & $\sqsubset$ \\
\hline $\begin{array}{l}\text { Ürünler hakkındaki önemli gerçekler tanıtıcı (infomercial) } \\
\text { reklamlarda yer almaz }\end{array}$ & $\sqsubset$ & $\sqsubset$ & $\sqsubset$ & $\sqsubset$ & $\sqsubset$ \\
\hline Tanıtıcı (infomercial) reklamlar eğlencelidir & $\sqsubset$ & $\sqsubset$ & $\sqsubset$ & $\sqsubset$ & $\sqsubset$ \\
\hline Tanitıcı (infomercial) reklamlar zevklidir & $\sqsubset$ & $\sqsubset$ & $\sqsubset$ & $\sqsubset$ & $\sqsubset$ \\
\hline Tanitıcı (infomercial) reklamlar memnuniyet vericidir. & $\sqsubset$ & $\sqsubset$ & $\sqsubset$ & $\sqsubset$ & $\sqsubset$ \\
\hline Tanıtıcı (infomercial) reklamlar rahatsız edicidir & $\sqsubset$ & $\sqsubset$ & $\sqsubset$ & $\sqsubset$ & $\sqsubset$ \\
\hline $\begin{array}{l}\text { Tanıtıcı (infomercial) reklamların insan zekâsını aşağıladığını } \\
\text { düşünüyorum. }\end{array}$ & $\sqsubset$ & $\sqsubset$ & $\sqsubset$ & $\sqsubset$ & $\sqsubset$ \\
\hline Çok fazla tanıtıcı (infomercial) reklam var. & $\sqsubset$ & $\sqsubset$ & $\sqsubset$ & $\sqsubset$ & $\sqsubset$ \\
\hline Infomercial reklama zorla maruz bırakıldığımı düşünüyorum. & $\sqsubset$ & $\sqsubset$ & $\sqsubset$ & $\sqsubset$ & $\sqsubset$ \\
\hline Infomercial reklamlar tarafından saldırıya uğradığımı düşünüyorum. & $\sqsubset$ & $\sqsubset$ & \ulcorner & $\sqsubset$ & $\sqsubset$ \\
\hline
\end{tabular}




\begin{tabular}{|c|c|c|c|c|c|}
\hline $\begin{array}{l}\text { 6. Lütfen aşağıdaki soruları kişilik özelliklerinize göre } \\
\text { değerlendirerek kesinlikle katılmıyorum-katılmıyorum-ne } \\
\text { katılıyorum ne katılmıyorum- katılıyorum-kesinlikle } \\
\text { katılıyorum şeklinde cevaplandırını. }\end{array}$ & 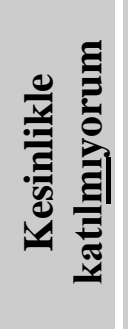 & 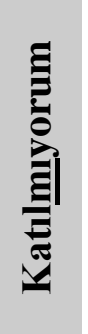 & 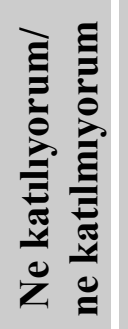 & בֶ. & 这 \\
\hline Alışveriş yaparken (ürüne/mekana) güven duymak isterim. & $\sqsubset$ & $\sqsubset$ & $\sqsubset$ & $\sqsubset$ & $\sqsubset$ \\
\hline $\begin{array}{l}\text { Herhangi bir ürün satın almadan önce o ürüne güvenebileceğimden } \\
\text { emin olmak isterim. }\end{array}$ & 正 & $\sqsubset$ & $\sqsubset$ & $\sqsubset$ & $\sqsubset$ \\
\hline Riskli ürünler almaktan kaçınırım. & $\sqsubset$ & 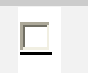 & $\sqsubset$ & 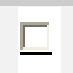 & $\sqsubset$ \\
\hline Yeni ürünlerde şansımı denemeyi severim & $\sqsubset$ & $\sqsubset$ & ᄃ & $\sqsubset$ & 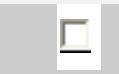 \\
\hline $\begin{array}{l}\text { Alışveriş yaparken farklı kanalları denemeyi severim. (örn. } \\
\text { İnternet,tv) }\end{array}$ & $\sqsubset$ & $\sqsubset$ & $\sqsubset$ & $\sqsubset$ & $\sqsubset$ \\
\hline Yeni ürünler daima hilelidir. & $\sqsubset$ & ᄃ & \ulcorner & ᄃ & 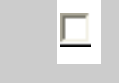 \\
\hline Genellikle en ucuz ürünü satın alırım & $\sqsubset$ & $\sqsubset$ & $\sqsubset$ & $\sqsubset$ & $\sqsubset$ \\
\hline Genellikle indirimdeki ürünü satın alırım & $\sqsubset$ & $\sqsubset$ & $\sqsubset$ & $\sqsubset$ & $\sqsubset$ \\
\hline S1k sık kendimi fiyatları kontrol ederken bulurum. & $\sqsubset$ & $\sqsubset$ & $\sqsubset$ & $\sqsubset$ & $\sqsubset$ \\
\hline Bir insanı pek çok kere alışverişte pazarlık yaparken görebilirsiniz. & $\sqsubset$ & $\sqsubset$ & $\sqsubset$ & $\sqsubset$ & $\sqsubset$ \\
\hline $\begin{array}{l}\text { Ürünün fiyatının reklamda gösterilmesi o reklama olan ilgimi } \\
\text { arttırır. }\end{array}$ & 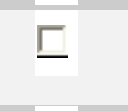 & 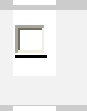 & 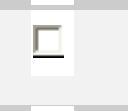 & 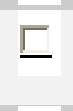 & $\sqsubset$ \\
\hline $\begin{array}{l}\text { Reklamları izledikten sonra yine de en düşük fiyatı olan ürünü satın } \\
\text { alırım. }\end{array}$ & ᄃ & $\sqsubset$ & ᄃ & $\sqsubset$ & $\sqsubset$ \\
\hline Genellikle bildiğim markalı ürünleri satın alırım. & $\sqsubset$ & $\sqsubset$ & $\sqsubset$ & $\sqsubset$ & $\sqsubset$ \\
\hline Mağazalarda satılan markalarının kalitesi düşüktür. & $\sqsubset$ & $\sqsubset$ & $\sqsubset$ & $\sqsubset$ & $\sqsubset$ \\
\hline Tanınmış bütün markalar aynıdır. & $ᄃ$ & $\sqsubset$ & $ᄃ$ & 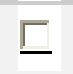 & $\sqsubset$ \\
\hline $\begin{array}{l}\text { Reklamı yapılan markaya harcadığım para, reklamı yapılmayan } \\
\text { markaya harcadığım paradan daha değerlidir. }\end{array}$ & $\sqsubset$ & $\sqsubset$ & $\sqsubset$ & $\sqsubset$ & 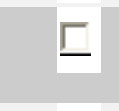 \\
\hline Çeşitli ve farklı ürünleri denemeyi severim. & $\sqsubset$ & $\sqsubset$ & $\sqsubset$ & $\sqsubset$ & $\sqsubset$ \\
\hline Çeşitli ve farklı türde alışveriş yapmayı severim. & $\sqsubset$ & $\sqsubset$ & $\sqsubset$ & $\sqsubset$ & $\sqsubset$ \\
\hline Yeni ve farklı stilleri severim. & $\sqsubset$ & $\sqsubset$ & $\sqsubset$ & 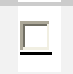 & $\sqsubset$ \\
\hline Genellikle plansızca alışveriş etmekten hoşlanırım. & ᄃ & $\sqsubset$ & $\sqsubset$ & $\sqsubset$ & $\sqsubset$ \\
\hline Geçici bir hevesle bir şeyleri almayı severim. & $\sqsubset$ & $\sqsubset$ & $\sqsubset$ & 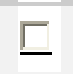 & $\sqsubset$ \\
\hline Alışveriş etmeden önce iki kere düşünürüm. & $\sqsubset$ & $\sqsubset$ & $\sqsubset$ & $\sqsubset$ & $\sqsubset$ \\
\hline Daima alışveriş listeme sadık kalırım. & 든 & $ᄃ$ & ᄃ & $\sqsubset$ & ᄃ \\
\hline
\end{tabular}




7. Tanıtıcı (infomercial) reklamlarda müşteriyi ikna etmek
amaçlı kanıtlar kullanılmaktadır. Bu kanıtlar; ürünü
kullandıktan sonra memnun kaldığını anlatan bir tüketici, ürün
ile ilgili bir uzman (örn, doktor, spor hocası vb.) ve ürünün
özelliklerini anlatan bir sunucu yer alırken, ayrıca ünlü kişilere,
ürünlerin yararlarının karşılaştırılmasına ve çş̧itli hediyelere
rastlanır. Lütfen bu özellikleri göz önünde bulundurarak
aşağıdaki soruları yanıtlayınız.

Tanıtıc1 (infomercial) reklamlarda ki memnun tüketicilerin yorumları benim satın alma kararımda etkilidir.

Tanıtıcı (infomercial) reklamlarda ki uzman kişinin yorumları benim satın alma kararımda etkilidir.

Tanitıcı (infomercial) reklamlarda ki sunucu benim satın alma kararımda etkilidir.

Televizyon veya reklam filmlerinden tanıdığım bir ünlünün, tanıtıcı (infomercial) reklamlarda, ürün hakkında konuşması satın alma kararımda etkilidir.

Tanıtıcı (infomercial) reklamlarda ürünlerin yararlarının karşılaştııılması benim satın alma kararımda etkilidir.

Tanıtıcı (infomercial) reklamlarda sipariş verdiğimde yanında verilen hediyeler/ek ürünler (bıçak seti yanında yemek kitabı/bir alana ikinci üründe hediye gibi) satın alma kararımda etkilidir.

Farklı işlevlerdeki pek çok ürün yerine tüm işlevlerin tek bir üründe toplandığını gösteren tanıtıcı (infomercial) reklamlar satın alma kararımda etkilidir.

\section{Tanıtıcı (infomercial) reklamların tüketiciye ulaşırken sunduğu kolaylıklar ve ödeme koşulları gibi özelliklerini göz önünde bulundurarak aşağıdaki soruları yanıtlayınız.}
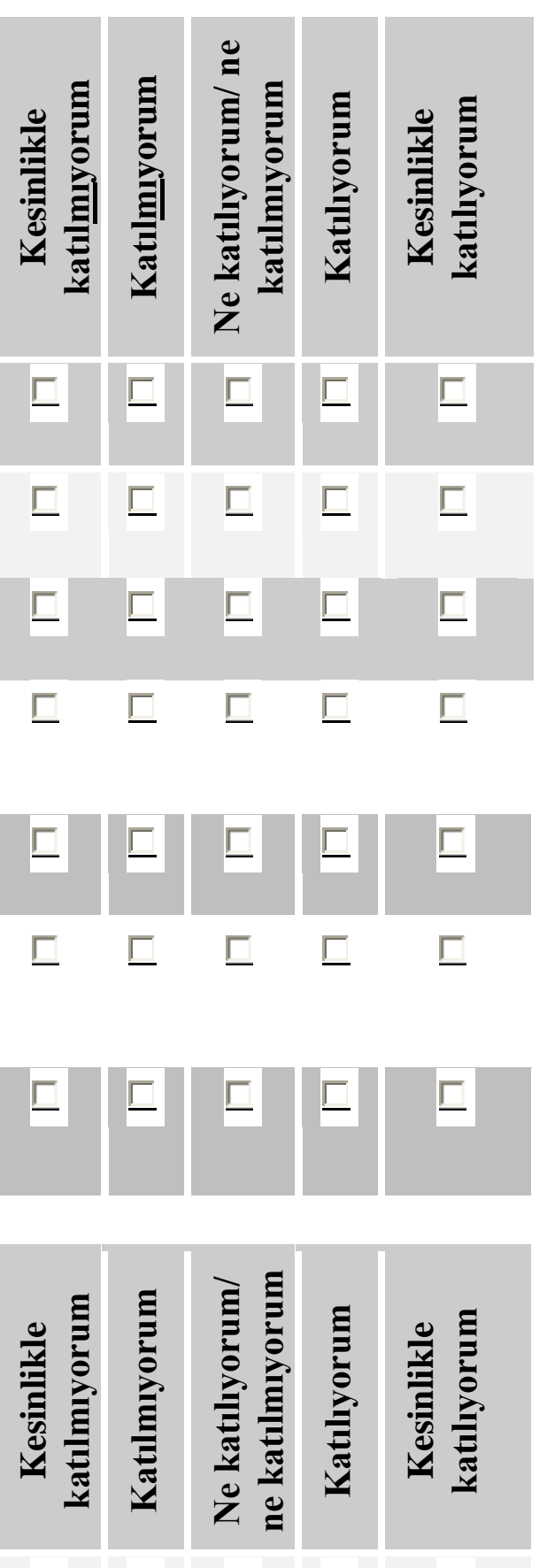

Tanıtıc1 (infomercial) reklamlarda kredi kartıyla ödeme yapılabilmesi satın alma kararımda etkilidir.

Tanıtıcı (infomercial) reklamlarda kredi kartına taksitli/peşin ödeme koşulları satın alma kararımda etkilidir.

Tanıtıcı (infomercial) reklamlarda memnun kalmadığım ürünü iade ettiğimde, paramı geri iade garantisi satın alma kararımda etkilidir.

Tanıtıcı (infomercial) reklamlarda ürünün fiyatı hakkında bilgi verilmesi satın alma kararımda etkilidir.

Tanitıcı (infomercial) reklamlarda telefon numarası verilmesi benim satın alma kararımda etkilidir.

Tanitıcı (infomercial) reklamlarda internet adresi verilmesi benim satın alma kararımda etkilidir.

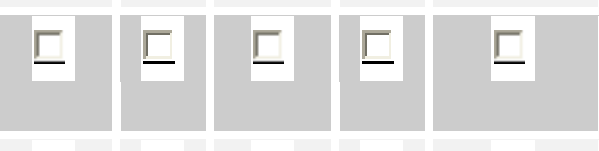

ㄷㄷㄷㄷ

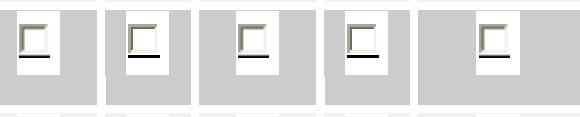

ㄷㄷㄷㄷ

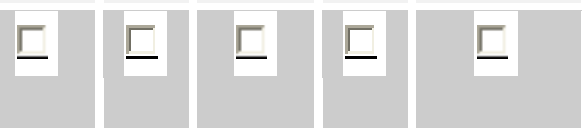


Tanitıc1 (infomercial) reklamların kargo ile evime teslim edilmesi benim satın alma kararımda etkilidir.

Tanıtıcı (infomercial) reklamlar zamandan tasarruf ederek, evden alışveriş yapma kolaylığı sağladığı için satın alma kararımda etkilidir.

Tanıtıcı (infomercial) reklamın süresi satın alma kararımda etkilidir.

Tanıtıcı (infomercial) reklamın uzun süre ürün özelliklerini anlatması satın alma kararımı etkiler

Tanıtıc1 (infomercial) reklam süresinin uzun olmasının ürünün fiyatına yansıdığını düşünürüm, bu da satın alma kararımı olumsuz etkiler.

ㄷㄷㄷㄷㅡ L] IE

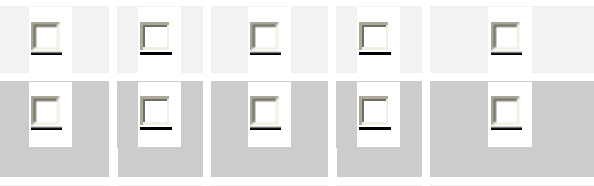
$\sqsubset \sqsubset \sqsubset \square \square$

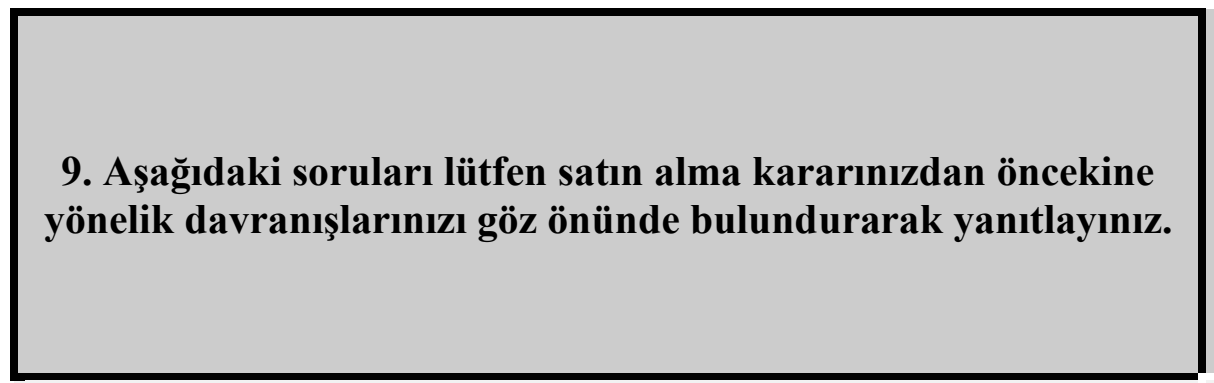

Bir ürünü satın almadan önce reklamlarına bakarım.

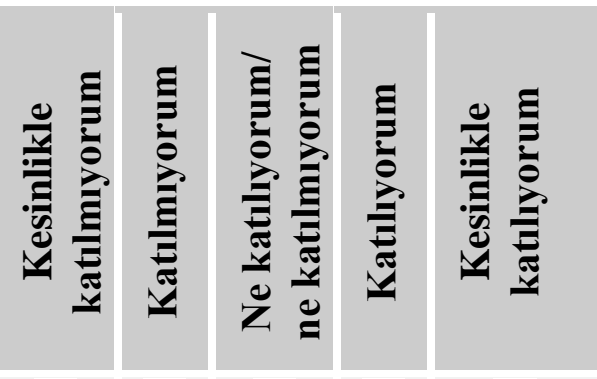

ㄷㄷㄷㅡ

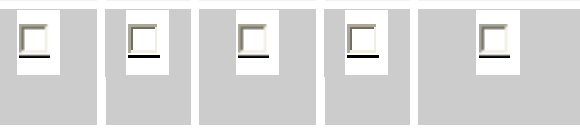

Televizyon reklamında görmeden önce, bir ürüne ihtiyacım olduğunu fark etsem bile, asla hiçbir ürüne bakmam. Tanıtıcı (infomercial) reklamlarda tanıtılan ünlerden satın almadan
önce reklam hakkında çok düşünürüm.

Tanıtıcı (infomercial) reklamlar satın almadan önce ürün hakkında düşünmemi sağlar

Tanıtıc1 (infomercial) reklamlarda bir ürünü neden satın almam gerektiğini söyler. Bu nedenler hakkında düşünürüm.

Tanıtıcı (infomercial) reklamlardan satın almaya karar vermeden önce, ürünün fayda sağlayıp, saylamayacağı hakkında düşünürüm

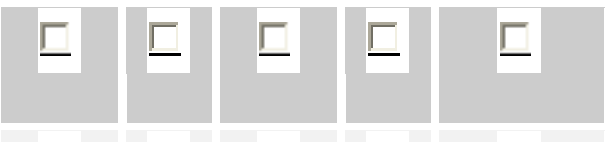

ㄷㄷㄷㄷㅡ

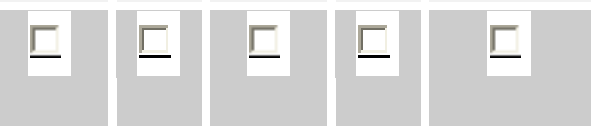

$\sqsubset \sqsubset \square \sqsubset \square$ 


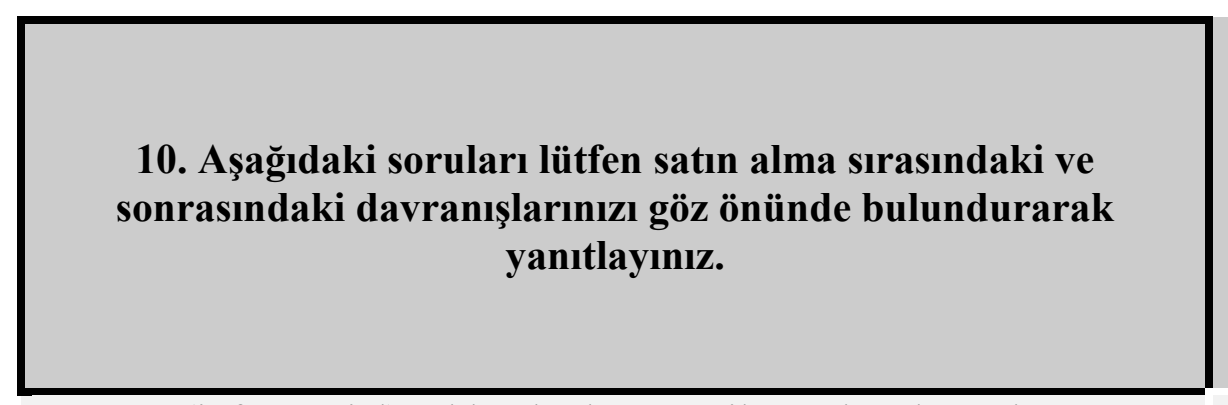

Tanıtıcı (infomercial) reklamlarda gösterilen pek çok marka ve ürün arasından seçim yaparken, hangi ürünü satın alacağım önemlidir.

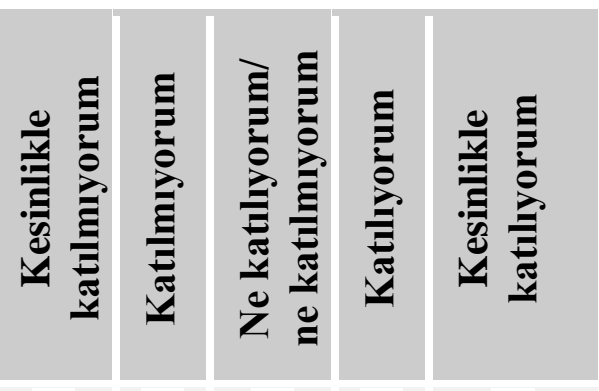

ㄷㄷㄷㄷㅡ

Tanıtıcı (infomercial) reklamlarda ki çeşitli tür ve markadaki ürünler birbirine benzemektedir.

Tanıtıcı (infomercial) reklamlardan doğru ürün seçimi yapabilmek önemlidir.

Tanıtıcı (infomercial) reklamlardan bir ürün seçerken, seçimimin sonucunda beni tatmin edip etmeyeceği ile ilgili endişeleniyorum.

Tanıtıcı (infomercial) reklamlardan önümüzdeki bir hafta içerisinde tekrar satın almayı düşünüyorum.

Tanıtıcı (infomercial) reklamlardan önümüzdeki bir ay içerisinde tekrar satın almayı düşünüyorum.

Tanıtıcı (infomercial) reklamlardan önümüzdeki bir yıl içerisinde tekrar satın almayı düşünüyorum.

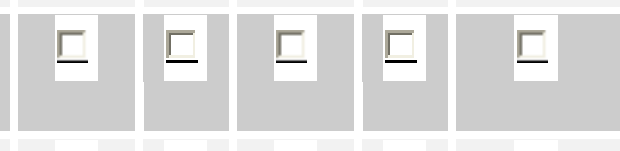

ㄷㄷㄷㄷㅡ

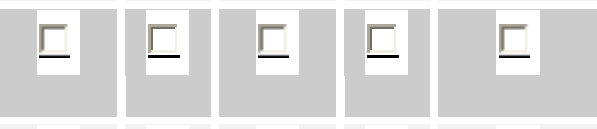

ㄷㄷㄷㅡ

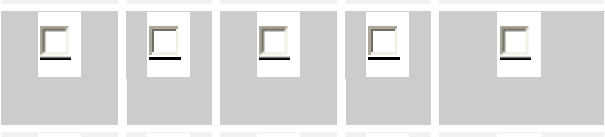

ㄷㄷㄷㅡ

Tanıtıcı (infomercial) reklamlardan satın aldığım ürünü arkadaşlarıma tavsiye etmeyi düşünüyorum.

Tanıtıcı (infomercial) reklamlardan satın aldığım ürünü aileme tavsiye etmeyi düşünüyorum. 


\section{DEMOGRAFİK ÖZELLİKLER}

Cinsiyetiniz:

$\Gamma$ Kadin

Yaşınız:

Г 16-24

Г 25-34

$\Gamma 35-44$

Aylık geliriniz:

Г 750 TL ve alti

Г 751-1500 TL

$\ulcorner 1501-2000 \mathrm{TL}$

Г 2001-2500 TL

Г2501-3000 TL

En son mezun olduğunuz okul:

ГIlkögretim

$\Gamma$ Lise

ГYüksekokul

$\Gamma$ Üniversite

Г Yüksek lisans

$\Gamma$ Diger belirtiniz.

Medeni durumunuz:

$\lceil$ Evli $\quad \Gamma$ Bekar

Г Boşanmiş $\quad \Gamma$ Dul

Varsa çocuk sayısı:

Г Yok

Г 1 Tane

$Г 2$ Tane

$\lceil 3$ Tane veya daha fazla

Haneye giren aylık toplam gelir:
$\lceil 750 \mathrm{TL}$ ve alti
Г 3001-3500 TL
Г 751-1500 TL
Г 3501-4000TL
$\Gamma 1501-2000 \mathrm{TL}$
$\lceil 4001-4500 \mathrm{TL}$
Г2001-2500 TL
Г 4501-5000 TL
$\Gamma 2501-3000 \mathrm{TL}$
Г5001TL ve üstü

Mesleğiniz: Lütfen Belirtiniz

ANKETİMIZE KATILDIĞINIZ İÇİN TEŞEKKÜR EDERİZ (; 